\title{
ESTUDIOS DE TEORÍA DEL DERECHO NATURAL
}

\section{JOHN FINNIS}


ESTUDIOS DE TEORÍA DEL DERECHO

NATURAL 


\section{INSTITUTO DE INVESTIGACIONES JURÍDICAS}

Serie Estudios JuRídicos, núm. 312

COORDINACIÓN EDITORIAL

Lic. Raúl Márquez Romero

Secretario Técnico

Lic. Wendy Vanesa Rocha Cacho

Fefa del Departamento de Publicaciones

Rosa María González Olivares

Cuidado de la edición

José Antonio Bautista Sánchez

Formación en computadora

Edith Aguilar Gálvez

Elaboración de portada 


\section{JOHN FINNIS}

\section{ESTUDIOS DE TEORÍA \\ DEL DEREGHO NATURAL \\ JAVIER SALDAÑa SERRANO CARlos I. MASSINI CORREAS \\ Editores}
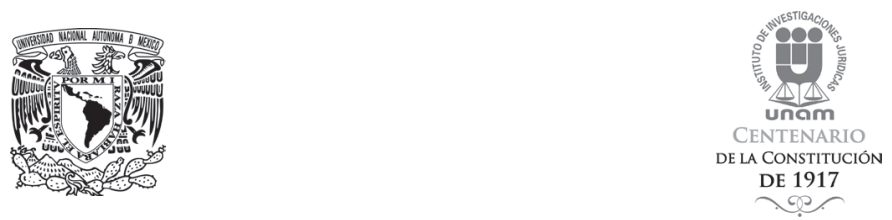

UNIVERSIDAD NACIONAL AUTÓNOMA DE MÉXICO INSTITUTO DE INVESTIGACIONES JURÍDICAS MÉXICO, 2017 
Primera edición: 14 de diciembre de 2017

DR C 2017. Universidad Nacional Autónoma de México

\section{INSTITUTO DE INVESTIGACIONES JURÍDICAS}

Circuito Maestro Mario de la Cueva s/n

Ciudad de la Investigación en Humanidades

Ciudad Universitaria, 04510 Ciudad de México

Impreso y hecho en México

ISBN 978-607-02-9742-7 


\section{CONTENIDO}

PRÓlOGO ....................... IX Javier SALDAÑA SERRANO

ESTUDIO PRELIMINAR A JOHN FINNIS: TEORÍA DEL DEREGHO NATURAL . . . . . . . . . . . XXI Carlos I. MASSInI-CORREAS

¿QUÉ ES LA FILOSOFÍA DEL DERECHO? . . . . . . . . 1

I. Jurisprudencia o filosofía del derecho . . . . . . . . . 6

II. Teorías del derecho natural y positivismo . . . . . . 7

III. La normatividad jurídica como distinta de la normatividad moral. . . . . . . . . . . . . . . . . . . . 11

IV. Filosofía jurídica y nuevos desafios éticos y políticos . . 14

SOBRE LA INCOHERENCIA DEL POSITIVISMO JURÍDICO. . 17

LA “TRADICIÓN DE LA LEY NATURAL” . . . . . . . . . . 39

I. Contra el escepticismo ético, el dogmatismo, el convencionalismo . . . . . . . . . . . . . . . . . 40

II. Sobre la metodología de las ciencias sociales. . . . . . . 41

III. Críticas a las teorías agregativas del derecho . . . . . . . 43

IV. Una nota sobre la enseñanza de la jurisprudencia. . . . 44

ARISTÓTELES, SANTO TOMÁS Y LOS ABSOLUTOS

MORALES....................... 45 
TEORÍA DE LA LEY NATURAL $\ldots \ldots \ldots \ldots \ldots \ldots \ldots$

I. Posibilitando la positividad: los hechos sociales generan

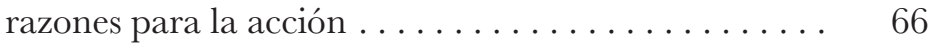

II. Las personas humanas no son creaciones del derecho sino su razón de ser . . . . . . . . . . . . . . . . . 80

III. Principios jurídicos para remediar el derecho positivo defectivo ....................... 82

IV. ¿"Lex iniusta non est lex”? ¿Las normas seriamente injustas obligan? ¿Obligan jurídicamente? . . . . . . . . 88

V. ¿Pueden las teorías generales del derecho ser libres de valoraciones? ¿De valoraciones morales?. . . . . . . . . 91

VI. Otros elementos de la teoría del derecho natural. . . . 95

REVISANDO LOS FUNDAMENTOS DE LA RAZÓN

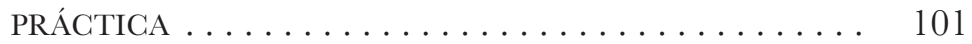

DERECHO NATURAL Y RAZONAMIENTO JURÍDICO . . . . 135

DERECHO, MORAL Y "ORIENTACIÓN SEXUAL" ...... 165

LA FILOSOFÍA DEL DERECHO: RAÍCES Y TEMAS

RECIENTES .................... 201

LEY NATURAL Y DERECHOS NATURALES,

30 AÑOS DESPUÉS . . . . . . . . . . . . . . . . . . . 227 


\section{PRÓLOGO}

Este libro que nos han encargado presentar reúne algunos de los más importantes trabajos escritos por el profesor John Finnis acerca de la teoría del derecho, en especial sobre la teoría del derecho natural, la mayoría de los cuales han sido traducidos y publicados en lengua castellana por prestigiosas revistas de filosofia del derecho. Algunos de estos trabajos han sido traducidos expresamente para el presente volumen por reconocidos teóricos del derecho iusnaturalistas. Pero lo importante es que, en su conjunto, estos estudios hacen posible tomar en cuenta y comprender las ideas de este destacado iusfilósofo australiano, residente en Oxford, que se ha constituido en el más relevante y original representante del pensamiento iusnaturalista de la segunda mitad del siglo XX y los inicios del presente.

En lengua castellana, la obra del profesor Finnis es ya bastante conocida, principalmente por la relevante traducción que el profesor chileno Cristóbal Orrego hiciera de la que sin duda es su más importante obra, Natural Law and Natural Rights, publicada con el título de Ley natural y derechos naturales por la editorial argentina Abeledo-Perrot en 2000. Antes, en 1992, se había publicado una traducción de Gabriel García Norro a otro de sus libros, $A b$ solutos morales, publicado por la editorial española EIUNSA. Por lo tanto, Estudios de teoría del derecho natural es el tercer libro de John Finnis que ve la luz en nuestro idioma, esta vez bajo el sello de la Universidad Nacional Autónoma de México (UNAM), específicamente de su Instituto de Investigaciones Jurídicas. Este Instituto, ya en 2013, había publicado sobre este autor el volumen colectivo Ley, moral y razón. Estudios sobre el pensamiento de Fohn M. Finnis, a propósito de la segunda edición de Ley natural y derechos naturales, compilado por el iusfilósofo argentino Juan Bautista Etcheverry. 
Antes de reseñar brevemente el contenido del presente libro, es conveniente describir en algunas líneas cómo se gestó la idea de dar vida a esta obra. Todo comenzó en una de las muy variadas estancias académicas que el profesor Carlos I. Massini Correas hiciera en México, en la que conversamos sobre la necesidad de ofrecer al público interesado una serie de argumentos renovadores del iusnaturalismo en este país, que se caracterizaran por entrar en diálogo con las restantes teorías jurídicas dominantes y que mostrara, de paso, la vitalidad e interés de la tradición iusnaturalista. Esto porque en el ámbito mexicano, el positivismo jurídico normativista ha ejercido una fuerte influencia, casi podríamos decir a niveles excluyentes, y aunque el derecho natural ha estado brillantemente representado por autores tan renombrados como los profesores Luis Recaséns Siches, Antonio Gómez Robledo, Agustín Basave Fernández del Valle, Eduardo García Máynez (en un cierto sentido), y más recientemente el filósofo analítico Mauricio Beuchot, faltaba una obra que le viniera a dar nuevos bríos a esta corriente de pensamiento, tan fuertemente defendida en México a lo largo de toda su historia jurídica, y excluida injustificadamente de los debates en los últimos tiempos.

Lo anterior nos llevó a pensar en la conveniencia de reunir en un volumen único la mayor parte de los trabajos traducidos al castellano de quien es hoy, sin duda, el más importante representante de la teoría clásica de la ley natural en el mundo anglosajón, el profesor emérito de la Universidad de Oxford, John M. Finnis, todavía catedrático Biolchini Family en la Universidad de Notre Dame (Indiana, EE. UU.). Así, el profesor Massini y quien estas líneas escribe nos dimos a la tarea de reunir - y en el caso del profesor argentino de traducir - varios de los diversos artículos del profesor Finnis. El resultado de este esfuerzo es el presente volumen.

Como se podrá observar, el libro se compone de diez trabajos, precedidos de un brillante e ilustrativo estudio introductorio del profesor Massini Correas sobre la vida y obra del pensador 
australiano. Es probable que en una primera impresión se pueda pensar que estos artículos no guardan ilación alguna, que son trabajos dispersos, pero en realidad esto no es así. Como se tratará de mostrar en el desarrollo de este prólogo, los compiladores nos hemos encargado de darles a todos estos trabajos una cierta unidad, un hilo discursivo unitario que presente los trabajos que componen el libro en forma secuencial. Por otra parte, quizá valga la pena dejar claro desde el principio que el objetivo de la exposición que sigue es, simplemente, el de entusiasmar al lector y animarlo a profundizar en la lectura detenida del mismo, por lo que sólo se delinean algunos aspectos de los trabajos que componen el volumen, y se remarca su unidad conceptual.

La unidad a la que nos referimos comienza a mostrarse desde el primer capítulo del libro, el cual aborda la pregunta básica que todo profesor de filosofía del derecho se ha hecho alguna vez, a saber: ¿qué es la filosofía del derecho? Éste es el cuestionamiento inicial del que parte Finnis, estableciendo desde el primer momento de su análisis que este particular tipo de filosofía pertenece a la razón práctica, entendida como aquella que procura hacer razonables las deliberaciones y elecciones que las personas toman en cada una de sus acciones, en especial las jurídicas.

Comprender la filosofía jurídica como parte de la razón práctica conlleva igualmente otro tipo de consideraciones sobre el derecho que el profesor John Finnis destaca también. Así, por ejemplo, expone argumentos tan importantes como el de la unidad de la razón práctica y de las materias que la integran (ética, política y derecho), o el de cómo las elecciones que hacemos tienen como finalidad la consecución del bien común como concepto clave del derecho (idea ésta que, como sabemos, fue rechazada por Kelsen). Del mismo modo, el profesor Finnis no se cansa de insistir en que la filosofia del derecho apela directamente a la ética para comprender mejor los bienes humanos básicos, o de reconocer que la descripción completa del derecho pasa necesariamente por el derecho positivo, etcétera. Éstos y otros temas son explicados detalladamente por el profesor Finnis en el primer capítulo, 
dedicado a exponer que la filosofía del derecho es parte de la razón práctica en su dimensión filosófica.

Una vez establecida la cuestión inicial, Finnis aborda uno de los tópicos más provocativos para cualquier filósofo del derecho contemporáneo: el del fuerte cuestionamiento que ha recibido en nuestro días el paradigma dominante en buena parte de la cultura jurídica occidental, incluyendo, claro está, la mexicana. Me refiero al positivismo jurídico - a la Kelsen-. Naturalmente, Finnis no escribió este trabajo pensando en la cultura jurídica mexicana, pero he marcado este énfasis porque, desde hace mucho tiempo y en diferentes lugares del mundo, el positivismo jurídico normativista ha recibido fuertes críticas, hasta el límite de que, en algunos casos, como el de Manuel Atienza, se sostiene que habría que abandonarlo.

La crítica y propuesta de abandono de esta particular forma de entender y explicar el derecho se ha debido a diferentes factores, pero ha sido la necesidad de la inclusión de elementos morales, y por tanto valorativos, en el derecho, lo que en gran medida ha motivado su pérdida de hegemonía. Y no es que el actual positivismo jurídico excluya dicho elemento moral, sino que es la forma en que lo incorpora lo que lo hace inconsistente. Por eso Finnis no duda en calificar al actual positivismo como incoherente.

Son muchas las razones por las que el profesor Finnis califica de incoherente al positivismo jurídico actual, y faltaríamos al propósito de este prólogo si diéramos cuenta de todas ellas. Pero quizá todas éstas puedan ser resumidas en unas cuantas líneas, como magistralmente lo ha hecho Orrego, al dejar establecido que resulta cuando menos extraño pensar que el positivismo jurídico actual establezca que el derecho son razones para la acción de tipo jurídico, pero - como lo hace Hart - rechace al mismo tiempo la obediencia a las leyes cuando son injustas, para terminar reconociendo finalmente - como lo hace Raz - la apelación a normas no jurídicas (morales) como criterios de respuesta a los problemas jurídicos. 
Establecida la pregunta inicial, y explicada la principal incoherencia del positivismo jurídico, Finnis pasa, en un breve trabajo, a delinear lo que la tradición de la ley natural ha representado en la historia de occidente, explicando esta ley como aquel conjunto de proposiciones verdaderas que identifican los bienes humanos básicos, los requerimientos de elección correctos y las normas morales como directivas genéricas para la acción. Esta ley es caracterizada por Finnis a través de tres notas identificatorias, a saber: (i) el rechazo del escepticismo ético en cualquiera de sus formas (dogmatismo y convencionalismo); (ii) la aclaración de la metodología de las ciencias sociales, entre descriptivas, explicativas y directivas, y (iii) la oposición a cualquier intento de defender concepciones agregativas de lo correcto y lo justo (consecuencialismo y utilitarismo, principalmente).

Las tesis anteriores, aunque breves, son muy complejas y en muchos casos han sido objeto de diferentes críticas, quizá por la poca precisión con la que han sido presentadas. Estas críticas muchas veces parten de las erróneas interpretaciones que se han hecho de los dos más importantes teóricos del derecho natural clásico, a saber: Aristóteles y Tomás de Aquino. Pero Finnis se encarga, en el capítulo "Aristóteles, Santo Tomás y los absolutos morales", de hacer una serie de puntualizaciones sobre algunas de estas interpretaciones a lo señalado por estos pensadores. El punto es muy concreto y puede resumirse en una pregunta: ¿Aristóteles y Tomás de Aquino reconocieron la existencia de absolutos morales, es decir, de prohibiciones morales que no admiten excepción bajo ninguna circunstancia? La respuesta que ofrece Finnis es afirmativa y no se cansa de explicar, con lujo de detalle, la justificación que estos pensadores dieron de dicho tópico de la filosofía y de la filosofía práctica.

En la misma línea argumentativa que el capítulo anterior, Finnis nos ofrece el trabajo titulado "Teorías de la ley natural", en el que igualmente se propone llevar a acabo una labor de esclarecimiento y de superación de algunos malentendidos que han generado los intensos debates entre iusnaturalistas y iuspositivis- 
tas. Son varios y muy ricos los argumentos que el autor australiano expone para hacer ver cómo dicha contienda secular, a más de partir de inexactitudes, ha provocado desgastes innecesarios en uno y otro bando. Para muestra de lo afirmado basta exhibir uno de los principales contrasentidos que ha generado el mencionado debate.

Según los críticos del derecho natural, éste no reconocería que el orden jurídico tuviera como base un hecho social, o que tal derecho ofreciera razones fuertes para actuar conforme a tales razones establecidas por la autoridad en las normas. Pero estas críticas son falsas y ningún iusnaturalista serio las suscribiría. Textualmente Finnis señala, siguiendo la tradición clásica, que las "teorías de ley natural aceptan que el derecho puede ser considerado o expuesto tanto como un puro hecho social de poder y práctica, como un conjunto de razones para la acción, que pueden ser y frecuentemente son sólidas en cuanto razones y por lo tanto normativas para la gente razonable a la que se aplican".

$\mathrm{Al}$ hilo de estas consideraciones y aclaraciones, Finnis aborda en forma más detallada y puntual el tema de los "Fundamentos de la razón práctica", el que, como su nombre lo indica, trata sobre las bases de la deliberación para saber qué elegir y qué hacer. Para el análisis específico de este tema, el profesor oxoniense comienza con el argumento del que partiría cualquier iusnaturalista serio, esto es, formulando una dura crítica a aquellas teorías que rechazan la noción de razón práctica, como fue la postura de Kelsen, para quien, como sabemos, la justicia es un ideal irracional. Por este motivo y según el profesor vienés, hablar de razón práctica es un sinsentido, porque si es razón no es práctica, dado que la práctica no puede ser racional.

La tesis anterior, como lo había mostrado antes la doctrina de la ley natural y lo ha repetido más recientemente alguna parte de la doctrina (v. gr. Alexy), hoy prácticamente nadie la sostiene. Más aún, como es fácil comprobar, asistimos hoy a una rehabilitación de la razón práctica. Esto, por sí solo, es digno de resaltar, pero la explicación más fuerte que Finnis da sobre los fundamen- 
tos de la razón práctica va encaminada a derrumbar la falsa tesis sostenida por los positivistas kelsenianos, en el sentido de aceptar que la validez del derecho pueda ser explicada suficientemente negando criterios materiales relativos al contenido del derecho. Dicho de otra forma, hoy existe una dura crítica a considerar que la validez jurídica sea sólo de carácter formal (sea por la autoridad competente que da la norma o por el procedimiento escalonado de su creación), para dar paso a un debate sobre una validez material o sustancial en el derecho. Finnis lo deja establecido claramente: ¿cómo se puede hablar seriamente de validez jurídica sin hacer referencia a aquellas consideraciones de contenido referidas a los sujetos, quienes necesitan recibir directivas coherentes y practicables de la autoridad para su convivencia, o reconocer el hecho de que las leyes deben cambiar cada cierto tiempo, o que los requerimientos y autorización del derecho deben ser conocidos por los sujetos, o que las disputas deben ser resueltas y que se deben facilitar las transacciones y su efectividad, etcétera? De ahí que se tenga que hablar de una nueva teoría de la validez jurídica que ya no es puramente formal, sino sustancial y, en un sentido más general, de carácter moral.

Otro de los capítulos integrados en el libro es el relativo al "Derecho natural y razonamiento jurídico". Aquí John Finnis ofrece una justificación del derecho natural y del razonamiento jurídico en general (principalmente el judicial), a partir de una explicación muy puntual de aquello que en su propuesta constituye el argumento central de su postura iusfilosófica: los bienes humanos básicos.

Igual que en el resto de los trabajos, son varios los razonamientos que el autor desarrolla en su artículo, pero quiero llamar la atención sobre uno de ellos, sobre todo porque este tema ha tomado una especial fuerza en los últimos años, particularmente en el ámbito de la filosofía del derecho. Me refiero al tema de las emociones. Si tuviera que formularse en términos de un interrogante la relevancia de este tema, quizá la pregunta sería la siguiente: jjuega algún papel el tema de las emociones en la 
justificación del derecho natural?, ¿'los iusnaturalistas han considerado alguna vez el tema de las emociones? En rigor, pareciera que nos estamos preguntando sobre si las emociones ocuparon la atención de los autores más representativos del derecho natural clásico, como Aristóteles o Tomás de Aquino, o si este asunto hoy merecería alguna preocupación académica por parte de Finnis.

Este tema es especialmente significativo para cualquier iusnaturalista y, contra lo que pueda pensarse, el iusnaturalismo clásico ha presentado sólidos argumentos sobre el argumento de las emociones. Finnis, por ejemplo, asiente positivamente a este punto al señalar que todas nuestras acciones tienen una motivación emocional que involucra nuestros sentimientos, así como otros elementos de nuestra corporeidad, pero, aclara, estas acciones son motivadas racionalmente, es decir, tienen también una motivación inteligente, ya que buscan realizar un bien inteligible.

Otro tema igual de controvertido como el anterior es el de la orientación sexual y la respuesta que puede ofrecer el derecho natural a tal cuestionamiento. Lo que Finnis califica como "posición europea predominante" muestra claramente que las políticas de Estado, por ejemplo las de Inglaterra hasta antes de la década de los noventa, específicamente las de orden jurídico, prohibían la exhibición y promoción de actos homosexuales, y aunque se pensara que hoy esto ha cambiado radicalmente, no es del todo así. Hoy también los Estados dejan perfectamente establecido por medio de leyes y políticas públicas que no pueden renunciar a su legítimo interés en la moral pública, y en consecuencia a ofrecer una educación tanto a niños como a jóvenes orientada a lo que es realmente valioso, así como tampoco pueden renunciar a un hecho decisivo de cara a una consideración reflexiva sobre un hecho actual, esto es, "que una vida envuelta en conductas homosexuales es mala".

Casi en la última parte del libro y en una especie de balance conclusivo, Finnis vuelve a tratar varios temas centrales que identifican a la filosofía del derecho de nuestro tiempo y que deja suficientemente en claro para que no se vuelva a incurrir en impre- 
cisiones. Uno es el tema de considerar y aceptar — como lo haría cualquier iusnaturalista - que el derecho es el derecho positivo, o para usar sus propias palabras en el debate iusnaturalismo $v s$. iuspositivismo, que

cada una es una teoría del derecho positivo, es decir, del derecho hecho por o adoptado - impuesto - por una específica comunidad, por personas identificables que pretenden tener la autoridad de hacer o aplicar reglas cuya validez se deriva inmediatamente (si no finalmente) del hecho de que esas personas las han hecho autoritativamente $\mathrm{o}$, al menos, las han determinado.

Sin duda, ésta podría ser una primera conclusión que, como se ve, ofrece una noción de derecho que cualquier jurista, sea iusnaturalista o no, podría suscribir sin ningún reparo.

Es importante poner énfasis en la idea anterior por varias razones. Una es que cuando los iusnaturalistas hablan de derecho natural y explican, por ejemplo, el tema de la naturaleza humana, no están hablando solamente de una naturaleza metafisica. En el caso de Finnis, por ejemplo, claramente establece que hablar de naturaleza humana en el ámbito de la razón práctica es hacer referencia a aquel conjunto de bienes humanos básicos que si son seguidos, ayudan al florecimiento humano en todos sus aspectos básicos.

Los iusnaturalistas han aceptado siempre la tesis de que en la consideración general del derecho, el derecho positivo juega un papel fundamental. Así lo reconoció, entre otros, Aristóteles, quien nos había enseñado que el derecho de la polis es natural y legal, igual que lo comentaría después Tomás de Aquino. En este sentido, Finnis reconoce igualmente que el derecho positivo es también relevante porque a través de él, por ejemplo, se hacen obligatorias acciones que antes de ser establecidas no eran obligatorias. Del mismo modo, el derecho es derecho positivo, porque sin reducir la sanción a la pura coacción penal, el derecho ha de apelar a ella para prohibir con la fuerza las relaciones interpersonales deshonestas o negligentes. 
Después de hacer un repaso por el pensamiento de los más significativos teóricos de la filosofía del derecho contemporánea, Finnis se detiene en Hart para mostrar que a partir de este pensador ya nadie se atreverá a negar la presencia de elementos morales en el derecho y de sus consecuentes juicios de valor. El problema, sin embargo, es cómo tienen presencia esos elementos morales y a qué tipo de moral se refiere.

Este no es el lugar para hacer comentarios laudatorios a los aportes que Hart hizo a la filosofía del derecho, pero sí es importante destacarlos por el papel que tuvieron en la obra de Finnis. Algunos de éstos son: la crítica que hiciera Hart a Austin y a Kelsen con su propuesta de las reglas como razones para la acción, más que como normas para coaccionar; la distinción entre el sentido focal y los sentidos derivados del derecho; la diferenciación entre el punto de vista interno y el punto de vista externo también en el derecho. Todos estos representan, sin duda, significativos aportes de la filosofía analítica del derecho que Finnis consideró en su obra y sin los cuales ésta difícilmente se entendería.

El último capítulo del libro, titulado "Ley natural y derechos naturales, 30 años después", recoge las reflexiones que presentó el profesor de Oxford con ocasión, precisamente, de las tres décadas de la aparición de su libro. En rigor, estos pensamientos son una gran evaluación personal de cómo Finnis observa el panorama actual, no sólo del mundo en general, sino de los logros y alcances de la filosofía del derecho de hoy. Por supuesto que resulta especialmente atractivo el balance que hace el profesor oxoniense porque, desde una mirada crítica y a tres décadas de sus iniciales reflexiones filosóficas, da cuenta de sus alcances y también de sus limitaciones, pero, sobre todo, plantea nuevos interrogantes y líneas de trabajo por donde posiblemente discurran las venideras aventuras iusfilosóficas de la sociedad occidental.

Como se advirtió al inicio de estas líneas, la intención de este prólogo no ha sido otra que tratar de provocar algún tipo de entusiasmo entre el público interesado por la filosofía del derecho 
mexicana para poder acercarse a un estudio serio y riguroso del derecho natural, realizado por quien ya puede ser considerado un clásico de la filosofía del derecho, un pensador que ha sabido entender y exponer, con la mayor rigurosidad intelectual posible, los fundamentos que han sostenido y mantendrán aún viva - suponemos que por mucho tiempo - lo que Robert P. George llamara, siguiendo a I. Berlin, la "tradición central de occidente".

Javier SALDAÑa SERRANO

Santiago de Chile, invierno de 2017 


\section{ESTUDIO PRELIMINAR A JOHN FINNIS: TEORÍA DEL DEREGHO NATURAL}

\section{Dominus illuminatio mea*}

\section{EL AUTOR Y LA OBRA}

Una de las ideas más atrayentes y más difundidas en la filosofía contemporánea es la del carácter tradicional que revisten casi todas las empresas filosóficas. El más notorio difusor y defensor de esta idea es el filósofo escocés residente en los Estados Unidos, Alasdair MacIntyre. ${ }^{1}$ En varios de sus libros, pero en especial en After Virtue ${ }^{2}$ y Three Rival Versions of Moral Inquiry, ${ }^{3}$ el multifacético pensador escocés ha desarrollado la idea de que no es posible pensar - se entiende que pensar con cierta profundidad y provecho - fuera de alguna tradición de pensamiento e investigación. Pero quien ha resumido de modo magistral esta idea de la dependencia-detradiciones ha sido el filósofo italiano Giuseppe Abbà:

ningún filósofo - escribe - comienza a pensar desde cero; antes bien, se encuentra enfrentado a aquellos problemas filosóficos

* Lema de la Universidad de Oxford. John Finnis afirma, en el prefacio de Natural Law and Natural Rights, que este lema debería colocarse en la parte final de ese libro.

1 Sobre MacIntyre, véase Matteini, M., MacIntyre e la rifondazione dell'etica, Roma, Città Nuova Editrice, 1995; y varios autores, Alasdair MacIntyre, ed. M. Murphy, Cambridge, Cambridge University Press, 2005.

2 MacIntyre, A., After Virtue. A Study in Moral Theory, 3a. ed., Notre DameIndiana, University of Notre Dame Press, 2007.

3 MacIntyre, A., Three Rival Versions of Moral Enquiry. Encyclopedia, Genealogy, and Tradition, Notre Dame-Indiana, University of Notre Dame Press, 2006. 
que le resultan planteados por la lectura que él ha hecho de la obra de otros filósofos... Esto, que vale para un filósofo individual, vale también para un conjunto de filósofos que adoptan, en diversos tiempos, la misma figura de filosofía moral elaborada por el fundador de una estirpe o escuela filosófica. Continuando su desarrollo, defendiéndola, corrigiéndola, modificándola bajo la presión de nuevos problemas, de nuevas objeciones, de nuevas críticas, de nuevas figuras, ellos dan vida a lo que se llama una tradición de investigación. ${ }^{4}$

Esta idea de un pensamiento dependiente-de-tradiciones no implica cerrazón a las ideas defendidas por otras tradiciones distintas y competitivas, ni inmovilismo, ni carencia de adaptación a los nuevos problemas y a las nuevas realidades. Antes bien, supone que no es posible pensar filosóficamente con beneficio y rigor sin un diálogo con otras vías de indagación, pero también que no se progresa en el pensamiento sino a partir de un punto de partida sólido y que no se pueden abordar eficazmente los nuevos problemas sin saber a ciencia cierta de dónde se viene y dónde se está parado. ${ }^{5}$ Por otra parte, y como consecuencia de lo anterior, fuera del pensamiento dependiente-de-tradiciones sólo quedan dos alternativas posibles: la originalidad radical de los genios de la filosofía o la esterilidad y pauperización de la especulación filosófica.

En el caso del presente libro, se trata de un conjunto de ensayos de filosofía práctica que se inscriben claramente en una tradición de pensamiento: la del iusnaturalismo clásico. Esta tradición, que fue designada por Isaiah Berlin como la "tradición central de occidente", ${ }^{6}$ tiene sus raíces en el pensamiento griego

4 Abbà, G., Quale impostazione per la filosofía morale?, Roma, LAS, 1996, p. 27.

5 Cfr. Massini-Correas, C. I., "Tradición, universalidad y dialéctica de las filosofias prácticas", en varios autores, Scientia, Fides Ë Sapientia. Escritos dedicados a Gustavo Eloy Ponferrada, La Plata, Argentina, ed. G. Delgado \& M. E. Sacchi, Ediciones Universidad Católica de La Plata, 2002, pp. 373-385.

6 Véase George, R. P., Making Men Moral. Civil Liberties and Public Morality, Oxford, Clarendon Press, 1995, p. 19. 
clásico de Platón y Aristóteles, atraviesa la especulación romana, principalmente con Cicerón, resurge en la baja Edad Media como una de sus corrientes principales, ejerce el cuasi-monopolio del pensamiento práctico en la Edad Moderna y - luego del paréntesis de la hegemonía positivista - resurge en la segunda posguerra como una corriente viva y presente en los debates iusfilosóficos contemporáneos.

Pero los ensayos aquí reunidos reconocen también otra raíz tradicional: la de la Analitic Furisprudence en la que fue formado su autor durante su juventud y que se conforma, por una parte, por el positivismo radical de Jeremy Bentham y John Austin, ${ }^{7}$ y por la otra, por el modo analítico de pensar, centrado en el lenguaje corriente y que tiene sus raíces en George E. Moore y el segundo Wittgenstein. ${ }^{8}$ Para la Analitic Furisprudence, el derecho está constituido exclusivamente por reglas que tienen su fuente en hechos sociales y cuya vía excluyente de acceso cognitivo está dada por el análisis lógico-semántico del lenguaje jurídico que usan corrientemente los operadores del derecho. Para esta perspectiva, al menos en algunos de sus autores centrales, en el derecho no hay casi lugar para valoraciones, ni principios morales, ni bienes humanos; se trata principalmente de mandatos de acción con un objetivo de mera supervivencia o de control social. ${ }^{9}$ El autor de

7 Sobre esta versión del positivismo, véase Hart, H. L. A., "Introduction", en Austin, J., The Province of Jurisprudence Determined, Indianapolis-Cambridge, Hackett Publishing, 1998, pp. vii-xxi; también, Marmor, A., Philosophy of Law, Princeton \& Oxford, Princeton University Press, 2011, pp. 35-59.

8 Acerca de la filosofía analítica, véase Tugendhat, E., Introduzione alla filosofia analítica, Genova, Marietti, 1989; y varios autores, Précis de philosophie analytique, ed. P. Engel, París, PUF, 2000.

9 Sobre la Analytic Furisprudence, véase, entre muchos otros, Shiner, R., Norm and Nature. The Movements of Legal Thought, Oxford, Clarendon Press, 1992, p. 199; Marmor, A., Positive Law and Objective Values, Oxford, Clarendon Press, 2001, pp. 49 y ss.; Bix, B., "Legal Positivism", en varios autores, The Blackwell Guide to the Philosophy of Law and Legal Theory, ed. M. P. Golding \& W.A. Edmundson, Malden-Oxford-Carlton, Blackwell Publishing, 2006, pp. 29-49; Finnis, J., "Legal Philosophy: Roots and Recent Themes", en Collected Essays: IV, Philosophy of Law, Oxford, Oxford University Press, 2011, pp. 157-173. 
estos ensayos adoptó inicialmente esta perspectiva, para abandonarla poco tiempo después y escribir sus trabajos teniéndola como principal oponente; pero no obstante este abandono y esta oposición, siguió conservando la problemática, el lenguaje y el estilo argumentativo de la Analitic Furisprudence.

En este contexto intelectual se inscribe el autor de los ensayos que componen este libro, John Mitchell Finnis, actualmente profesor emérito de Furisprudence (Teoría del Derecho) en la Universidad de Oxford, y docente e investigador en la Universidad de Notre Dame, Indiana, como Biolchini Family Professor of Law. Finnis nació en 1940 en Adelaide, South Australia, donde realizó sus estudios escolares - en la South Australia Church of England School- y universitarios de grado, recibiéndose de Abogado en la University of Adelaide. Cabe destacar que tanto su padre como su abuelo materno eran profesores de filosofía en esa misma universidad. Después de recibido, a los 21 años, ganó la Rhodes Scolarship correspondiente a 1962, para realizar estudios de posgrado en la Universidad de Oxford, donde llevó a cabo sus cursos e investigaciones de doctorado bajo la supervisión del profesor H. L. A. Hart. Estos trabajos culminaron en 1965 con su tesis doctoral sobre The Idea of Fudicial Power, en la que se estudiaba el tema con referencia principal al derecho constitucional federal australiano.

Además de sus estudios doctorales, Finnis leyó con provecho el libro central del jesuita canadiense Bernard Lonergan, Insight, ${ }^{10}$ que lo ayudó a desembarazarse de los prejuicios empiristas adquiridos en su educación formal, y también algunas de las obras del Beato John Henry Newman referidas a la revelación cristiana. Asimismo, ya estando en California, comenzó la lectura de las obras de Germain Grisez, profesor en el Mount St. Mary's University de los Estados Unidos, en especial su conocido artículo "The First Principle of Practical Reason. A Commen-

10 Lonergan, B. J. F., Insight. A Study of Human Understanding, London, Longmans, Green \& Co., 1964 (la primera edición es de 1957). 
tary on the Summa Theologiae 1-2, Question 94, Article 2", ${ }^{11}$ en el que descubrió un nuevo approach a los textos clásicos de la teoría de la ley natural que resultaba inmune a la acusación positivista de incurrir en la denominada "falacia naturalista". Años más tarde, Finnis realizó varios trabajos de filosofía y teología moral en colaboración con Germain Grisez.

Ya doctorado, comenzó una carrera académica que lo llevó a enseñar primero - por recomendación de Hart - en la Universidad de Berkeley en California, entre 1965 y 1966; al finalizar este curso, fue designado tutor en derecho en el University College de la Universidad de Oxford, donde ha enseñado - con algunos breves intervalos - desde 1966 hasta la actualidad. En 1971 tuvo a su cargo un curso en la Universidad de Adelaide, en 1993/94 enseñó en el Boston College de los Estados Unidos, y entre 1976 y 1978 fue docente e investigador en la Universidad de Malawi, un pequeño estado africano, ubicado en el sudeste del continente, entre Zambia y Mozambique, y que tiene al inglés como uno de sus idiomas oficiales. Allí aprovechó para escribir la mayor parte de Natural Law and Natural Rights, que fue su primer libro importante y el que sentó las bases de su vasto renombre en el mundo académico y jurídico. ${ }^{12}$

$\mathrm{Su}$ carrera en la Universidad de Oxford fue especialmente destacada; como ya se dijo, en 1966 fue designado tutor del University College, al que ha pertenecido desde entonces y donde tuvo su despacho por décadas, durante un tiempo ubicado exactamente sobre el que ocupaba Ronald Dworkin. Entre 1972 y 1989 fue Rhodes Reader en el derecho del British Commonwealth y de los Estados Unidos, y desde 1989 ejerció como Professor in Law \& Legal Philosophy, con la máxima categoría docente que se puede alcanzar en esa Universidad. De modo concomitante con lo an-

11 Grisez, G., "The First Principle of Natural Law. A Commentary on the Summa Theologiae, 1-2, Question 92, Article 2", Natural Law Forum, Notre Dame, núm. 10, 1965, pp. 168-196.

12 Véase Orrego, C., "Estudio preliminar", en Finnis, J., Ley naturaly derechos naturales, trad. de C. Orrego, Buenos Aires, Abeledo-Perrot, 2000, pp. 9-32. 
terior, fue designado entre 1986 y 1991 miembro de la Comisión Teológica Internacional de la Santa Sede, y desde 1989 integra la British Academy. Además, Finnis ejerció también la profesión de abogado, asesorando a numerosos estados australianos en materias constitucionales y como abogado miembro del Gray's Inn de la English Bar ante varias cortes de apelaciones. Entretanto, llevaba adelante en la Universidad de Oxford un seminario periódico de filosofía del derecho, junto con Herbert Hart y Joseph Raz, en el que se debatían públicamente los temas más polémicos de la teoría jurídica y de la filosofía práctica.

Por otra parte, John Finnis había sido educado religiosamente - como la mayoría de los niños anglosajones - en el cristianismo anglicano, pero al alcanzar la adolescencia no practicaba la religión que, en general, lo tenía sin demasiado cuidado: a todos los efectos prácticos, era un agnóstico. Pero entonces leyó un libro apologético escrito por un sacerdote poco conocido, pero que le hizo replantearse los problemas del cristianismo y comenzar un proceso de conversión, proceso que culminó con su bautismo como fiel de la Iglesia católica, el 19 de diciembre de 1962, en la iglesia de St. Aloysius de Oxford. Finnis comparte esta religión con su esposa - Carmel McNally, graduada en literatura inglesa - y en la que fueron educados sus seis hijos. ${ }^{13}$ Como intelectual católico, Finnis se ha desempeñado en el Reino Unido como directivo del Linacre Centre for Health Care Ethics (hoy Anscombe Bioethics Centre), como asesor del Catholic Bishops's Joint Comitee on Bioethical Issues (1981-88), y en el Vaticano, como miembro de la Comisión Teológica Internacional (198692), del Consejo Pontificio Justicia y Paz (1990-95) y de la Academia Pontificia Pro Vita, desde 2001 hasta la actualidad.

En lo que respecta a su obra publicada, ya se dijo que su primer libro relevante fue $\mathcal{N}$ atural Law and Natural Rights (en adelante NLNR), publicado en 1980 en la prestigiosa colección de Oxford

13 En este punto, puede verse: wrww.twotlj.org/Finnis.htme, consulta del 16 de abril de 2013. 
University Press, Clarendon Law Series, y que le había sido encargado por uno de los directores de la colección, Herbert Hart, catorce años antes. Este libro fue objeto de numerosas reimpresiones y recientemente se ha editado una segunda edición por Oxford University Press, ${ }^{14}$ la que contiene un extenso Postscript (65 pp.), en el que Finnis aclara varias de sus doctrinas e interpretaciones y responde a algunas de las críticas que se han dirigido al libro. No cabe duda que este libro, algunas de cuyas afirmaciones han sido corregidas, ampliadas y aclaradas por su autor en escritos posteriores, es uno de los textos relevantes de la filosofía del derecho contemporánea. En efecto, son pocos los volúmenes de filosofía jurídica - y, en general, de filosofía práctica - que han sido objeto de más referencias, recensiones, artículos, notas críticas y citas que NLNR.

Sobre este libro, el iusfilósofo positivista Neil Mac Cormick escribió:

pocas veces he leído una obra de filosofía con un mayor sentimiento de excitación y descubrimiento que el que experimenté en la primera recorrida sin aliento a través de la pre-edición de Natural Law... Él [libro] sigue siendo para mí un hito intelectual; uno de esos pocos libros que hacen surgir un cambio permanente en la propia comprensión; una transformación en el propio paradigma personal. ${ }^{15}$

Y por su parte, el pensador iusnaturalista Mark Murphy, que profesa en la universidad de Georgetown, sostiene:

14 Finnis, J., Natural Law and Natural Rights, 2a. ed., Oxford, Oxford University Press, 2011, 494 pp. (en adelante se citará NLNR, haciendo siempre referencia a la segunda edición). También influyó de modo importante en la mutación de las ideas de este autor la lectura del libro central del jesuita canadiense Bernard Lonergan; Lonergan, B. J. F., Insight. A Study of Human Understanding, London, Longmans, Green \& Co., 1964 (la primera edición es de 1957).

15 MacCormick, N., "Natural Law and the Separation of Law and Morals", en varios autores, Natural Law Theory. Contemporary Essays, ed. R. P. George, Oxford, Oxford University Press, pp. 105 y 106. 
es bastante claro que la resurrección contemporánea del punto de vista estricto de la ley natural, en el marco de la iusfilosofía analítica, data del libro de John Finnis de 1980, Natural Law and Natural Rights. Las tesis defendidas por Finnis en esa obra cubren todo el espectro de campos filosóficos en los que las doctrinas de la ley natural han sido defendidas... y esas explicaciones se encuentran, del mismo modo que las ofrecidas por el teorizador paradigmático de la ley natural, Tomás de Aquino, fuerte y adecuadamente integradas. ${ }^{16}$

En ese libro, su autor reformuló la doctrina clásica del derecho natural, presentándola en el lenguaje, las estructuras argumentativas y la temática propias de la teoría jurídica analítica dominante en Gran Bretaña desde mediados del siglo XIX. Finnis conocía muy bien esa tradición, ya que había sido formado en ella, tanto en sus estudios de grado como de posgrado, hasta "el momento - escribe Finnis - en que comencé a sospechar que podría haber algo más que superstición y tinieblas en las doctrinas de la ley natural". ${ }^{17}$ Este nuevo estilo de presentación trastocó completamente la imagen del iusnaturalismo compartida por la gran mayoría de los juristas y pensadores del derecho, según la cual se trataba de una doctrina dogmática, primitiva y basada en fundamentos exclusivamente religiosos. Es más, se referían a él con la etiqueta de "iusnaturalismo teológico" y lo exponían en una síntesis ridícula y caricaturesca, hasta el extremo en que resultaba difícil entender cómo alguien en la historia del pensamiento podía haber sostenido semejante bobería; las varias presentaciones efectuadas por Hans Kelsen del iusnaturalismo resultan muy ilustrativas a ese respecto. ${ }^{18}$

16 Murphy, M., "Natural Law Jurisprudence", Legal Theory, Cambridge, núm. 9, 2003, p. 241.

17 Ibidem, p. vi.

18 Entre otros lugares, véase Kelsen, H., "The Natural Law Doctrine Before the Tribunal of Science", The Western Political Quarterly, Salt Lake City-Utah, vol. II, núm. 4, 1949, pp. 481-513. 
En este sentido, la presentación realizada por Finnis en NLNR obligó a los estudiosos de la teoría jurídica a tener en cuenta al iusnaturalismo como una corriente filosófica razonable y que tenía algo que decir en el debate de las ideas contemporáneas. Según lo resume muy bien Orrego,

Finnis volvió a poner sobre la mesa cuestiones como la inextricable unión de las valoraciones - morales, en último término- y las descripciones en las ciencias sociales; la necesidad de explicar el derecho positivo en el contexto más amplio de la razonabilidad práctica y de los bienes humanos básicos fundantes del orden moral; la teoría de la justicia, de la obligatoriedad del derecho, del bien común, de la autoridad, de los derechos humanos naturales; el problema de la ley injusta, considerado a la vez desde el punto de vista jurídico, político y moral, sin excluirlo de la teoría analítica del derecho, e incluso la cuestión de Dios como fundamento último del orden moral. ${ }^{19}$

Paradojalmente, luego de un momento de desconcierto inicial, el libro fue resistido duramente en los ambientes más conservadores del iusnaturalismo clásico de raíz tomista, que no comprendieron o no tuvieron en cuenta su estructura argumentativa analítica, ni hacia quienes estaba dirigido, ni la índole de la formación intelectual de su autor, ni las ideas de los autores a los que se oponían las principales tesis del libro. En el Postscript de la segunda edición de NLNR, Finnis se refiere a estas incomprensiones diciendo que:

19 Orrego, C., op. cit., p. 14. Sobre el impacto intelectual de NLNR, Fulvio di Blasi ha escrito: "Este libro, en efecto, desde su primera aparición, se ha impuesto a la atención general de los estudiosos de ética, derecho y política como el esfuerzo más imponente y original de retomar críticamente los temas clásicos del derecho natural y de los derechos naturales, que en la filosofía del derecho contemporánea, sobre todo la de matriz analítica, habían caído al presente en un descrédito total"; Di Blasi, F., Dio e la legge naturale. Una rilettura di Tommaso d'Aquino, Pisa, Edizioni ETS, 1999, p. 22. 
quedé desconcertado por la inhabilidad o poca voluntad de los escritores modernos de esa tradición [de la ley natural] para enfrentarse a los estudiantes seculares de nuestros días, tal y como están equipados intelectualmente por sus maestros de colegio y los periodistas con puntos de vista derivados de Hume y Russell $\mathrm{u}$ otras variantes del escepticismo moderno acerca del bien y el mal, lo correcto e incorrecto en la acción humana, y con el determinismo cientista, el materialismo y otras concepciones (e.g., el positivismo lógico) acerca de las limitaciones de la razón. Por ello no debí haberme sorprendido, como lo fui, por la inhabilidad y la poca voluntad de los recensionistas y otros lectores de la tradición más o menos Tomista, para tomar en cuenta el género del libro y la audiencia a la que estaba dirigido primariamente, como parte integral de la Clarendon Law Series... El libro era, pensaron, una capitulación ante Hume y su falacia "Ser y Deber-Ser". ${ }^{20}$

Es cierto que el libro no tenía la estructura expositiva de los manuales clásicos de filosofía tomista y de ius naturae, en los que la explicación de la ley natural era precedida de una larga introducción epistemológica, antropológica y metafísica, y en los que se suponía que la audiencia estaría formada por jóvenes católicos practicantes o simplemente por seminaristas. En este abandono de las formas expositivas y en algunas otras afirmaciones discutibles, los representantes de un tomismo excesivamente estructurado e inmovilista creyeron ver una rendición incondicional ante las ideas del mundo moderno y un abandono de las tesis centrales de la tradición tomista. Buscaron en el libro sólo los puntos en los que se apartaba de la ortodoxia tomista y no sus contribuciones a la mejor comprensión de las tesis iusnaturalistas por parte de los lectores más o menos secularizados. Lamentablemente, se trata de un malentendido que no ha logrado todavía ser superado. ${ }^{21}$

20 NLNR, pp. 415 y 416.

21 En este punto, véase, como ejemplo, entre una bibliografía muy vasta: May, W. E., "Contemporary Perspectives on Thomistic Natural Law", en varios autores, St. Thomas Aquinas \& the Natural Law Tradition. Contemporary Perspectives, 
Después de la publicación de NLNR, Finnis publicó en 1982 Fundamentals of Ethics, que recoge el contenido de las $\mathrm{Ca}^{-}$ rroll Lectures impartidas en la Universidad de Georgetown; en 1987, Nuclear Deterrence, Morality and Realism, en asociación con Germain Grisez y Joseph Boyle; en 1991, Moral Absolutes. Tradition, Revision and Truth, que incluye el contenido de las f. McGivney Lectures ofrecidas en 1988 en la Catholic University of America, y en 1998 Aquinas. Moral, Political, and Legal Theory, que integra la colección Founders of Modern Political and Social Thought, editada por Mark Philp para Oxford University Press. Por otra parte, esa misma editorial publicó, en 2011, cinco volúmenes magníficamente editados de Collected Essays de John Finnis, con los siguientes títulos: Reason in Action, Intention \& Identity, Human Rights E Common Good, Philosophy of Law y Religion \& Public Reasons. Estos volúmenes, que totalizan más de dos mil páginas, incluyen la gran mayoría de los artículos y notas publicadas por Finnis a lo largo de más de cuarenta años de ardua labor y constituyen una fuente invalorable para el conocimiento de la integralidad y de la evolución de su pensamiento.

ed. J. Goyette et al., Washington D. C., The Catholic University of America Press, 2004, pp. 113-156; Long, S. A., "Natural Law or Autonomous Practical Reason: Problems for the New Natural Law Theory", en ibidem, pp. 165-193 (el primer trabajo defiende las ideas de Finnis y sus colegas; el segundo las impugna). Véase, asimismo, Lisska, A. J., Aquinas's Theory of Natural Law. An Analytic Reconstruction, Oxford, Oxford University Press, 1996; George, R. P., In Defense of Natural Law, Oxford, Oxford University Press, 2001; Donnelly, B., A Natural Law Approach to Normativity, Aldershot-Burlington, Ashgate, 2007, pp. 96 y ss.; Westerman, P., The disintegration of Natural Law Theory, Leiden-New York-Köln, Brill, 1998, pp. 231 y ss.; López Martínez, A., El debate anglo-americano sobre la teoría tomista de la ley natural, Roma, Pontificia Universitas Sanctae Crucis, 2006; varios autores, Natural Law \& Moral Inquiry, ed. R. P. George, Washington D. C., Georgetown University Press, 1998; y varios autores, The Revival of Natural Law. Philosophical, theological and ethical responses to the Finnis-Grisez School, ed. N. Biggar \& R. Black, Aldershot, Ashgate, 2000. Puede verse también la bibliografía citada por Orrego, C., op. cit., passim. 


\section{LA TEORÍA FINNISIANA DEL DERECHO: LA PERSPEGTIVA METÓDICA DE ABORDAJE}

Una de las características principales de la empresa intelectual encarada por John Finnis es que su propuesta de teoría del derecho se encuentra enmarcada en el contexto de un sistema completo de filosofía práctica: la suya es una filosofía del derecho que supone una filosofía política y una ética general. En lo que sigue del presente estudio, la investigación se centrará en los aspectos más propios de la teoría del derecho, dando por supuestas o mencionando sólo incidentalmente las doctrinas morales y políticas con las que se encuentra vinculado. En otros lugares, el autor de estas líneas se ha referido in extenso a esos temas y resultaría reiterativo volver a desarrollarlos aquí. ${ }^{22}$ Por ello, se hará un esfuerzo de análisis descompositivo, concentrando el desarrollo de las ideas del profesor oxoniense en sus aspectos más propiamente jurídicos, es decir, en su elaboración de una teoría del derecho iusnaturalista y en las críticas que dirige a algunos de sus principales oponentes: los positivistas jurídicos.

Finnis comienza su teoría del derecho con algunas precisiones metodológicas acerca del modo en que se abordará el estudio de su objeto, y hace especial hincapié en dos de ellas: la primera referida al carácter principalmente práctico de la aproximación y de la explicación acerca de lo jurídico, y la segunda acerca del uso de la llamada analogía de atribución como instrumento para determinar el caso central del derecho y la significación focal del correspondiente término "derecho". Respecto de lo primero,

22 Véase, principalmente, Massini-Correas, C. I., "The New School of Natural Law. Some Approaches”, Rechtstheorie, Berlín, núm. 30-4, 1999, pp. 461478; "Derechos humanos y bienes humanos", en Teoría del derecho y de los derechos humanos, Lima-Perú, ARA Editores, 2011, pp. 23-51; "Sobre ciencia práctica y prudentia. Aproximaciones desde las ideas de John Finnis", Sapientia, Buenos Aires, núms. 227 y 228, 2010, pp. 41-53; "Sobre razón práctica y naturaleza en el iusnaturalismo. Algunas precisiones a partir de las ideas de John Finnis", Rivista Internazionale de Filosofia del Diritto, Milano, núm. 89-4, 2013, pp. 497-517. 
Finnis precisa que "el desarrollo de la teoría del derecho sugiere, y la reflexión sobre la metodología de cualquier ciencia social confirma, que un teórico no puede proporcionar un análisis y descripción teorética de los hechos sociales a menos que también él participe en la tarea de valorar, de comprender qué es realmente bueno para las personas humanas y qué exige realmente la racionalidad práctica", y esto es así, toda vez que "las acciones, prácticas, etc., solamente pueden comprenderse plenamente captando su fin, es decir, su objetivo, su valor, su relevancia o importancia, tal como fueron concebidos por quienes realizaron esas acciones, participaron en esas prácticas, etc.”. ${ }^{23}$

Para Finnis, esta necesidad de atención central al punto de vista práctico se revela claramente en la crítica de Hart a Austin y a Kelsen, en la que el antiguo profesor oxoniense pone de relieve que la doctrina de esos autores no se adecuaba a los hechos pertinentes, aclarando Finnis que

los hechos a los que esa teoría no se adecuaba, según Hart, eran hechos acerca de las funciones... La descripción ("concepto") del derecho de Hart se construye apelando, una y otra vez, al fin práctico de los componentes del concepto. El derecho ha de describirse en términos de reglas para la orientación de funcionarios y de ciudadanos por igual, y no meramente como un conjunto de predicciones de lo que harán los funcionarios... El derecho debe establecer sanciones y un contenido mínimo de reglas primarias con el fin de garantizar la supervivencia de la sociedad o de sus miembros y para darles a éstos una razón práctica para conformarse con él. ${ }^{24}$

Pero además, en su obra posterior, Aquinas. Moral, Political, and Legal Theory, Finnis precisa que

23 NLNR, p. 3.

24 NLNR, pp. 40 y 41. En este punto, véase Covell, Ch., In Defence of Natural Law. A Study on the Ideas of Law and Fustice in the Writings of Lon Fuller, Michael Oakeshott, F.A. Hayek, Ronald Dworkin and John Finnis, London, MacMillan, 1999, pp. 198 y 199. 
lo que es práctico, es acerca de qué cosa hacer... No es acerca de lo que es el caso, tampoco acerca de lo que será el caso. Es acerca de lo que ha de ser hecho, debe ser hecho - una prescripción y no, en cuanto tal, una predicción-. Si uno tiene una intención, el propio conocimiento de esa intención es, primero y principalmente, conocimiento práctico, un conocimiento del fin, del propósito que uno tiene y de los medios de la conducta propositiva. Como conocimiento práctico, es realmente conocimiento, verdadero y, en su propia dimensión, completo, aun cuando la conducta resulte impedida y nunca tenga lugar. ${ }^{25}$

\section{Un poco más adelante precisa que}

una ciencia o teoría es práctica en el sentido más pleno, si ella es acerca de y dirigida hacia aquello que es bueno hacer, tener, obtener y ser... Es práctica en su sentido más pleno cuando es acerca, y prescribe, lo que ha de ser hecho en el campo abierto a fines de la vida humana en su conjunto, por elecciones y actos... y en vista de objetos, fines-bienes que proveen razones para obrar y otorgan sentido a la vida individual o grupal como un todo abierto a fines. ${ }^{26}$

Aquí resulta conveniente recalcar que los autores contra los que escribe John Finnis - los positivistas estrictos - sostienen que el teórico social es un espectador de un espectáculo que puede tener cualquier fin-bien, y que es muy poco lo que puede decirse acerca de la razonabilidad de los fines. Finnis muestra que todo espectador indispensablemente habla del fin de la obra y lo valora, y esto es inevitable porque de lo contrario no se podría describir el espectáculo como tal espectáculo, es decir, saber que esto es un espectáculo y no una matanza, que esto es un espectáculo y no la vida real, etcétera Dicho de otro modo, que un análisis interesante y explicativo de la realidad social implica, de

25 Finnis, J., Aquinas. Moral, Political, and Legal Theory, Oxford, Oxford University Press, 1998, p. 38 (en adelante AQ).

26 Ibidem, p. 41. 
algún modo, el análisis de la razonabilidad de fines y bienes. Esto es así porque cuando nos preguntamos por el derecho nos preguntamos cuál es la decisión razonable, y la respuesta a esta pregunta implica: (i) la existencia de varios fines (y medios) eslabonados que hacen a una decisión razonable (o irrazonable); (ii) la aceptación de que esa cadena puede ser conocida. En esto último quizá resida el núcleo de la perspectiva práctica: al teórico del derecho no le interesa cualquier decisión, sino sólo la justa o razonable. ${ }^{27}$

La adopción de esta perspectiva resulta entonces indispensable para la explicación y comprensión de las realidades prácticas, toda vez que su sentido se revela a partir de los fines-bienes del obrar y sólo al que tiene acceso a esos fines, así como a las realidades vinculadas con ellos: normas, instituciones, facultades de hacer o de no hacer, etcétera. Esto es así, toda vez que la experiencia de la que parte más relevante del conocimiento ético y jurídico es intrínsecamente una experiencia práctica, colmada de valoraciones, directivas, intenciones, praxis intencionales e instituciones, que adquieren su sentido - y por lo tanto pueden ser comprendidas - sólo por referencia a fines-bienes humanos. Este punto de vista ha sido denominado por Giuseppe Abbà la "perspectiva de la primera persona", o "perspectiva del actor", que el autor italiano opone a la "perspectiva del espectador", o de la "tercera persona", que es la adoptada por la gran mayoría de los autores modernos, como Adam Smith en su Teoría de los sentimientos morales, o John Rawls en su Teoría de la justicia. ${ }^{28} \mathrm{Ha}$ escrito en este punto Abbà que "la vida buena, en cuanto vida $a$ conducir por parte de los individuos, es precisamente el tema de la Ética. Debe notarse que ella es considerada desde el punto de vista

27 Debo estas últimas consideraciones a una indicación del profesor Juan Cianciardo.

28 Véase Rawls, J., A Theory of Fustice, Cambridge-Massachusetts, The Belknap Press of Harvard University Press, 1971; Smith, A., La teoría de los sentimientos morales, trad. de C. Rodríguez Braun, Madrid, Alianza, 1997. 
de los agentes, en cuanto este es el fin que ellos realizan, la vida que practican, ejercitando su sabiduría práctica". ${ }^{29}$

Esto ocurre del mismo modo en el caso del derecho, toda vez que resulta imposible saber de qué estamos hablando si se hace abstracción de los fines para los que se sancionaron las normas, de los bienes a alcanzar mediante los actos jurídicos, los valores que presiden su regulación, el sentido propio del sistema jurídico-normativo, etcétera. El derecho - toda la realidad jurídicapertenece al orden práctico, ${ }^{30}$ aquel que la razón pone en las conductas en orden al bien humano. De aquí que la perspectiva adecuada - adecuada a su objeto - para la consideración del derecho sea la propia del agente de praxis, que reflexiona sobre el fin de cada institución jurídica y del derecho como un todo, y sobre los medios para alcanzarlos en la convivencia política. Esto se percibe especialmente en el caso de la interpretación jurídica, donde la desatención del aspecto valorativo-finalista torna imposible la realización de cualquier labor hermenéutica. ${ }^{31}$

\section{LA APROXIMACIÓN "ANALÓGICA”}

Pero esa aproximación práctica tiene otra nota relevante: se trata de un approach "analógico", es decir, que focaliza las consideraciones en el caso central de la realidad estudiada, para después pasar al análisis de aquellas otras concreciones de esa realidad en las que la significación principal del término - y del concepto - de que se trata se da de un modo determinado, o matizado, o imperfecto, o diluido, o parcial, o menguado, o aun desfigurado o pervertido.

29 Abbà, G., Quale impostazione per la filosofía morale?, Roma, LAS, 1996, p. 42. Véase Rhonheimer, M., La perspectiva de la moral. Fundamentos de la ética filosófica, trad. de J. Mardomingo, Madrid, Rialp, 2000, pp. 41 y ss.

30 Véase AQ, pp. 20-42.

31 Véase, entre otros lugares, Massini Correas, C. I., Objetividad jurídica e interpretación del derecho, México, Porrúa, 2008, passim. 
El campo propio de cualquier teoría o ciencia - escribe Finnisincluye propiamente todo lo que está relacionado con un tipo central y las formas relevantes de "relación con el tipo central" incluyen, inter alia, no sólo lo que genera realidades de ese tipo, sino también sus característicos defectos o corrupciones y las causas de esas frustraciones o fallas (breakdowns). Por lo tanto, una versión diluida o corrupta del tipo puede correctamente... ser llamada por el mismo nombre, aunque no exactamente con el mismo significado ("unívocamente", como traduce el Aquinate), ni de modo meramente equívoco, sino por el tipo de relación-enla-diferencia de significado que Tomás de Aquino (cambiando el vocabulario de Aristóteles) llama analogía. ${ }^{32}$

Finnis está haciendo referencia aquí a lo que tradicionalmente se ha denominado "analogía de atribución", figura lógica $-\mathrm{y}$ en definitiva ontológica - según la cual un término se aplica propia y formalmente a una cierta índole de realidades, pero también a otras de modo semejante pero no idéntico; esto es lo que sucede, $v$. gr., con términos como "luz" que se aplica de modo principal y formalmente al agente físico que hace visibles los objetos, pero también se dice de una persona inteligente que es una "luz", de Dios que es la "luz" del mundo, de un autor que dio a "luz" un nuevo libro, y del utensilio que sirve para alumbrar. En todos los últimos casos, la palabra se usa porque la realidad designada tiene una semejanza con el caso central, o porque es su causa o su efecto, o su condición, etcétera. ${ }^{33}$ Otro tanto ocurre en las realidades prácticas, tal como ocurre, v. gr., con la palabra "político", que se aplica con distintos grados de propiedad a un tipo de comunidad, a los grupos que intentan influir en el gobierno de esa comunidad, a un tipo de carácter especialmente dúctil

32 AQ, p. 43.

33 Sobre la noción de analogía, véase McInerny, R., Studies in Analogy, The Hague, Martinus Nijhoff, 1968; Gambra, J. M., La analogía en general, Pamplona, EUNSA, 2002; Montagnes, B., La doctrine de l'analogie de l'être d'aprés Saint Thomas d'Aquin, Louvain-Paris, Publications Universitaires de Louvain-Béatrice-Nauwelaerts, 1963. 
o a una cierta clase de actividades. En estos casos, el significado focal es el que corresponde a cierto tipo de actividad "política", aplicándose analógicamente a la comunidad en la que esa actividad se desarrolla, al tipo de carácter que la facilita y a los grupos que la realizan y promueven.

En este punto, Finnis agrega:

aprovechando la sistemática multiplicidad de significados de los términos teóricos que uno usa, se puede diferenciar lo maduro de lo inmaduro en los asuntos humanos, lo refinado de lo primitivo, lo plenamente realizado de lo corrompido, el buen ejemplar del caso desviado, lo que se dice "con propiedad", "sin restricciones" y "hablando de modo absoluto" (simpliciter), de lo que se dice "en cierto sentido", "por decirlo asín" y "de algún modo" (secundum quid), pero todo esto sin ignorar ni desterrar a otra disciplina los casos de la materia de estudio que sean inmaduros, primitivos, corrompidos, desviados o que de cualquier otra forma sean ejemplos sólo "en un sentido restringido" o bien "en un sentido amplio". ${ }^{34}$

En este lugar, Finnis equipara las nociones analógicas de atribución propia y formal y de atribución secundaria con las de predicación simpliciter y secundum quid, lo que Tomás de Aquino no hace expresamente, pero que - con las debidas precaucionespuede realizarse en ciertos casos.

En el caso de "derecho", Finnis sostiene que el "significado focal" es el que corresponde a "un punto de vista en el que el establecimiento y el mantenimiento de un orden jurídico, en cuanto distinto de uno discrecional o estáticamente consuetudinario, se considera un ideal moral, o bien una apremiante exigencia de justicia, entonces ese punto de vista constituirá el caso central del punto de vista jurídico". ${ }^{35}$ Dicho en otras palabras,

34 NLNR, pp. 10 y 11.

35 NLNR, pp. 14 y 15. En este punto, véase Pereira Sáez, G., La autoridad del derecho. Un diálogo con Fohn M. Finnis, Granada, Comares, 2008, pp. 17-39. 
para el pensador australiano, el significado principal de "derecho" incluye constitutivamente una dimensión ético-valorativa. Por ello es posible distinguir en este significado focal dos dimensiones centrales: (i) la que corresponde al ordenamiento jurídico positivo, que puede denominarse dimensión institucional, autoritativa o social-fáctica, y (ii) la que corresponde a un ideal racional o de justicia, que determina el sentido y la razón de ser del derecho. Ambas dimensiones integran lo que puede llamarse propiamente "derecho", y las atribuciones secundarias se referirán a aquellas realidades que realizan estas dos dimensiones de modo disminuido, parcial o imperfecto.

Esto es lo que un pensador relevante como Robert Alexy denomina el "carácter dual del derecho", 36 a lo que ha aludido recientemente N. E. Simmonds cuando afirma que el derecho consiste también en un "ideal moral", ${ }^{37}$ y que Finnis expone al decir que

durante la centuria que va desde alrededor de 1850 hasta aproximadamente 1950, la perspectiva prevaleciente entendía al derecho como una manifestación de poder, dominio y dirección, por la cual las personas o instituciones soberanas expresaban su voluntad acerca de cómo los miembros de la comunidad debían comportarse, y reforzaban estos imperativos con la amenaza y ejecución de sanciones. El punto de vista prevalente hoy en día no deja de lado la necesidad de sanciones impuestas por la fuerza a los recalcitrantes, pero enfatiza la oportunidad y la responsabilidad de los gobernantes de gobernar para el beneficio, no privado o partidista, sino común y de realizar esto por medios que tiendan

36 Véase Alexy, R., El concepto y la naturaleza del derecho (en adelante CND), trad. de C. Bernal Pulido, Madrid, Marcial Pons, 2008, p. 44. Sobre el pensamiento iusfilosófico de Robert Alexy, puede verse Vigo, R., "La teoría jurídica discursiva no positivista de Robert Alexy", en varios autores, La injusticia extrema no es derecho (de Radbruch a Alexy), ed. R. L. Vigo, Buenos Aires, Universidad de Buenos Aires-La Ley, 2004, pp. 25-71.

37 Véase Simmonds, N. E., Law as a Moral Idea, Oxford, Oxford University Press, 2008. 
a asegurar que todas las decisiones relevantes sean adoptadas en línea con la verdad acerca de los hechos y con transparencia e imparcialidad en los procedimientos legislativos, ejecutivos y judiciales. ${ }^{38}$

Finnis no desarrolla esta doctrina con la claridad que lo hace Alexy, ${ }^{39}$ pero es notorio que para el profesor de Oxford, el derecho, al menos en su "caso central", consta de dos dimensiones, elementos o co-principios: uno de ellos de carácter fáctico-social $y$ autoritativo, que se concreta en un sistema normativo positivo y en instituciones sociales que lo crean y aplican, y otro de índole racional-valorativo, que determina el sentido ético-práctico del sistema normativo y de las realidades jurídica a él vinculadas. Desde esta perspectiva, puede decirse que existen dos dimensiones en la validez del derecho: la fáctico-social y la racional-valorativa; sobre este tema se volverá más adelante.

38 Finnis, J., "Legal Philosophy: Roots and Recent Themes", en Collected Essays-IV (Philosophy of Law), Oxford, Oxford University Press, 2011, p. 157. En NLNR, Finnis sostiene que "todo esto [la positividad del derecho] no debiera oscurecer la medida en que el pensamiento jurídico de hecho sí permite (y razonablemente) que el sistema de reglas sea penetrado por principios de razonabilidad práctica que derivan su autoridad de su conveniencia (según justicia y en favor del bien común) y no, o no solamente, de su origen en algún acto pasado de disposición o en algún uso establecido. El sistema jurídico... es más abierto que lo que el modelo sugiere - es decir, más abierto al flujo ilimitado del razonamiento práctico, en el cual puede juzgarse que una disposición, válida según criterios formales de validez del sistema ("reglas de reconocimiento"), es, o ha llegado a ser, injusta y, por tanto, después de todo, total o parcialmente inaplicable-"; NLNR, p. 356.

39 En op. cit., pp. 44, Robert Alexy escribe: "dos propiedades son esenciales para el derecho: la coerción o fuerza, de un lado, y la corrección o rectitud, del otro. La primera se refiere al elemento central de la eficacia social del derecho; la segunda expresa su dimensión ideal o crítica". Y más adelante precisa que "el derecho implica necesariamente dos dimensiones: una dimensión real o fáctica y una dimensión ideal o crítica... Como consecuencia, qué sea el derecho es algo que depende no sólo de los hechos sociales, sino también de qué es aquello que el derecho debe ser" (p. 73). 
Lo que resulta importante destacar, en lo que se ha explicado hasta ahora, es que desde la perspectiva de John Finnis la aproximación propia del pensamiento acerca del derecho es, a raíz del carácter práctico del conjunto de realidades que se denominan "jurídicas" o "derecho", la perspectiva del agente de praxis, de quien piensa acerca de su obrar en procura del bien humano completo, es decir, del bien ético o bien moral. Dicho de otro modo: existe una clara continuidad en el pensamiento prácticomoral y el práctico-jurídico, y por lo tanto la perspectiva propia para el abordaje de las realidades jurídicas es la práctico-moral, que permite develar el sentido propio de lo jurídico y trascender una mera descripción de hechos sociales, que no podría establecerlos en cuanto jurídicos, ni comprender su sentido normativo. Este punto de vista práctico-moral equivale en varios sentidos - no en todos - al "punto de vista interno" 40 propugnado por Hart y es el que hace posible el desarrollo de una teoría jurídica práctica, ordenada a la comprensión del sentido y a la solución de las cuestiones jurídicas.

Ahora bien, esta perspectiva se enfrenta con una realidad - el derecho - múltiple y variada, compuesta por elementos que pertenecen a distintas categorías, y que no puede por lo tanto ser abordada sino de modo analógico, es decir, distinguiendo entre un caso central de aplicación del nombre, en el que el tipo o índole de esa realidad se da de un modo pleno y completo, y otros casos periféricos, en los cuales las realidades designadas realizan la índole analógica de modo imperfecto, disminuido o defectuoso. El punto de vista práctico permite determinar el caso central de "derecho" y establecer su significación focal, que es — según Finnis - la de un conjunto de normas producidas por una autoridad, dirigidas a resolver razonablemente y para su bien común los problemas de coordinación de la comunidad política. ${ }^{41}$

40 Hart, H. L. A., The Concept of Law, 2a. ed., Oxford, Oxford University Press (Clarendon Law Series), 1997, pp. 255 y passim.

41 NLNR, p. 276. 


\section{LA TEORÍA IUSNATURALISTA DEL DERECHO}

En un extenso artículo publicado en la Stanford Encyclopedia of Philosophy, con el título de "Natural Law Theories", 42 Finnis resume sus ideas respecto a la teoría del derecho que corresponde a una visión iusnaturalista - iusnaturalista clásica - de la realidad jurídica. Comienza aclarando que los iusfilósofos "positivistas" presentan sus planteos como radicalmente opuestos a los del iusnaturalismo, pero que en cambio los pensadores de la Natural Law Theory no hacen ningún esfuerzo por negar la mayoría de las tesis ius-positivistas; al contrario, para los iusnaturalistas,

el derecho puede ser considerado o expuesto tanto como un puro hecho social, cuanto como un conjunto de razones para la acción, que pueden ser y frecuentemente son sólidas en cuanto razones y por lo tanto normativas para la gente razonable a la que se aplican. Este carácter dual del derecho positivo está presupuesto en el eslogan bien conocido "el derecho injusto no es derecho". Entendido correctamente este eslogan indica porqué... la oposición positivista a las teorías del derecho natural es un sinsentido, ya que es redundante: aquello que los positivistas ven característicamente como realidades que deben ser afirmadas, son también afirmadas por la teoría del derecho natural, y aquello que ellos ven como ilusiones que deben ser disipadas, no es parte de la teoría del derecho natural. ${ }^{43}$

Esta es en rigor la tesis central del iusfilósofo australiano respecto de la oposición iuspositivismo-iusnaturalismo: el iusnaturalismo también sostiene las tesis principales propuestas por el iuspositivismo, más otras que completan la comprensión y explicación del fenómeno jurídico y la hacen más adecuada y acabada.

Para estas teorías iusnaturalistas — sostiene Finnis-,

42 Finnis, J., "Natural Law Theories" (en adelante NLT), en Stanford Encyclopedia of Philosophy, http://plato.stanford.edu/entries/natural-law-theories/, consulta del 10 de abril de 2013.

43 NLT, pp. 1 y 2. 
la cuestión central... es la siguiente: ¿cómo y porqué puede el derecho, y su positivación en la legislación, las decisiones judiciales y las costumbres, proporcionar a sus sujetos razones fuertes [es decir, obligatorias] para actuar de acuerdo con él? ¿Cómo puede la validez jurídica ("formal" o "sistémica") de una norma, juicio o institución, o su facticidad o eficacia como fenómeno social..., hacerlas autoritativas en las deliberaciones de sus sujetos. ${ }^{44}$

Para Finnis, la teoría del derecho natural sostiene que las normas "basadas en fuentes sociales" (legislación estatal, jurisprudencia, costumbre jurídica, etcétera) revisten una importancia central en la capacidad del derecho de promover el bien común, tal como lo sostiene Tomás de Aquino en un conocido texto de la Summa Theologiae, I-II, q. 95, a. 1. Todas esas teorías defienden que el derecho tiene también una dimensión moral, de búsqueda del bien humano y de exclusión de los grandes males sociales de la anarquía y la tiranía. ${ }^{45}$

Según Finnis, esta dimensión moral del derecho se descubre al considerar qué cosas ha de perseguir el hombre y qué cosas ha de evitar en su conducta; esta consideración lleva rápidamente a entender y asentir que ciertos estados de cosas, como la salud, el conocimiento, la armonía con los demás, etcétera, son intrínsecamente deseables para el hombre. Esta deseabilidad intrínseca de esos - y otros - estados de cosas se articula normativamente a través de "principios del razonamiento práctico fundacionales y no derivados", que promueven y dirigen hacia esos bienes inteligibles. Ahora bien, estos principios - denominados "principios de derecho natural" - reciben mayor especificidad de dos formas: (i) a través de una inferencia rigurosa que descubre lo que esos principios implican (conclusiones), y (ii) a través de una selección entre alternativas razonables de regulación, selección racional a través de una determinación (determinatio) de aquello que en los principios se encuentra indeterminado. En las comunidades

\footnotetext{
44 Ibidem, p. 3.

45 Ibidem, p. 4.
} 
políticas, "el modo habitual de llevar a cabo esas necesarias determinaciones, es la institución de la autoridad gubernamental, actuando en primera instancia a través de la legislación y de otras formas de generar normas, i. e., actuando como una fuente fáctico-social de derecho positivo". ${ }^{46}$

Aquí resulta conveniente hacer referencia, aunque sea de modo incidental, a las que Finnis denomina características principales del orden jurídico, que permiten distinguir al derecho de la política, las convenciones y usos sociales, la etiqueta, los juegos y de toda otra forma de interacción en comunidad. ${ }^{47}$ La primera de estas características - si bien Finnis la enumera separadamente - es la de ser un orden coactivo, es decir, que prevé ciertas desventajas para quienes incumplen sus imperativos, desventajas "que son parte de la empresa de ordenar jurídicamente a la sociedad, una empresa racionalmente exigida sólo por ese complejo bien de los individuos que denominamos el bien común". La segunda se refiere a que "el derecho introduce definición, precisión, claridad y por tanto previsibilidad en las interacciones humanas, mediante un sistema de reglas e instituciones interrelacionadas de tal manera que las mismas reglas definen, constituyen y regulan las instituciones y las instituciones a su vez crean y administran las reglas y resuelven las cuestiones sobre su existencia, alcance, aplicabilidad y funcionamiento", de modo tal que puede decirse que "el derecho regula su propia creación". ${ }^{48}$

La tercera característica es que cualquier regla o institución jurídica, una vez creada, permanece válida a lo largo del tiempo, hasta que sea derogada válidamente; la cuarta característica se refiere a que "las reglas de derecho regulan no solamente la creación, administración y aplicación de tales reglas, ...sino también las condiciones bajo las cuales un individuo privado puede modificar la extensión o la aplicación de las reglas" ${ }^{49}$ a través de actos jurídicos.

\footnotetext{
46 Ibidem, pp. 4 y 5.

47 Véase NLNR, p. 267.

48 Ibidem, p. 268.

49 Ibidem, pp. 268 y 269.
} 
La quinta se refiere a la cualidad del derecho, según la cual los actos jurídicos — públicos y privados - pasados tienen relevancia continua, es decir, proporcionan ahora razones suficientes y excluyentes para actuar de la manera prevista en su creación. Finalmente, la sexta remite al "postulado operativo" según el cual toda cuestión práctica o problema de coordinación actual ha sido "previsto" en todos sus aspectos por alguno de esos actos jurídicos pasados y, por lo tanto, no hay "lagunas" en el derecho. Finnis sintetiza estos caracteres en dos eslóganes: "el derecho es un orden coactivo" y "el derecho regula su propia creación". ${ }^{50}$

Luego de estas consideraciones acerca de los caracteres "formales" del derecho, Finnis dedica unas páginas - consecuentes con otras distribuidas a lo largo de varias de sus obras - a una defensa en toda la línea del gobierno del derecho (Rule of Law), en una versión de esa idea que no está basada en la mera autonomía, como sucede en el caso de las versiones liberales, sino centralmente en el bien humano común y la dignidad de las personas. Finnis argumenta esa idea a partir del famoso texto aristotélico de Política, III, 15, 1286 a ss., ${ }^{51}$ en el que el Estagirita desarrolla la idea de que - contra el pensamiento del primer Platón - "es mejor que gobierne la ley que cualquiera de los hombres", ${ }^{52}$ aunque se trate del mejor entre ellos. Para Aristóteles, sostiene el profesor de Oxford,

es preferible que el gobierno sea ejercido por o de acuerdo con las leyes, ya que: (i) las leyes son producto de la razón y no de las pasiones; (ii) la soberanía de un gobernante o de una asamblea tiende a la tiranía (i.e., el gobierno en interés de un grupo o facción, no del bien común); (iii) la igualdad demanda que cada persona madura tenga alguna participación en el gobierno; y (iv) la rotación de los cargos y de los que los ejercen es deseable y difícilmente puede ser

50 Ibidem, pp. 269 y 270.

51 Sobre la inteligencia de este texto, véase Castaño, S. R., "Brève analyse de l'empire de la loi chez Aristote", en Archiv für Rechts-und Sozialphilosophie, Stuttgart, núm. 83-4, 1997, pp. 548-554.

52 Aristóteles, Retórica, I, 1, 1354 a 32- b 16. 
manejado sin regulación legal. Por lo tanto - concluye Finnispara Aristóteles el caso central de autoridad práctica es el gobierno de una polis por la ley y por gobernantes reglados legalmente. ${ }^{53}$

Ahora bien, para el autor australiano, la doctrina de Tomás de Aquino es especialmente similar a la de Aristóteles, aunque pone mayor atención a los aspectos formales de la idea del gobierno del derecho. ${ }^{54}$ Por su parte, afirma Finnis, Lon Fuller, en su conocida obra The Morality of Law,

reconociendo el liderazgo del Aquinate en esta discusión de los aspectos formales y procedurales del sistema jurídico, reúne las puntualizaciones dispersas y fragmentarias realizadas en este tópico, en una lista ordenada de ocho elementos del gobierno del derecho... Fuller muestra que esos ocho elementos concuerdan como un conjunto de desiderata (o requerimientos) porque son implicaciones o especificaciones de la aspiración y el deber de tratar a la gente como presuntivamente dotadas de un título - como materia de imparcialidad y de justicia - a ser gobernados como personas libres, fundamentalmente iguales a sus gobernantes, y no como títeres o peones de ajedrez que pueden ser manejados y ordenados a través de la manipulación, la incertidumbre, el miedo, etc. ${ }^{55}$

En este punto, Finnis discute la interpretación de las ideas de Fuller realizada por Hart, Dworkin y Raz, según la cual los desiderata del rule of law propuestos en la obra de Fuller (publicidad, posibilidad y carácter previo de las normas, actividad de los gobernantes de conformidad con ellas, estabilidad y coherencia de

53 NLT, p. 7.

54 Sobre esta doctrina, véase Viola, F., "Legge umana, Rule of Law ed etica delle virtù in Tommaso d'Aquino", en Mangini, Michele \& Viola, Francesco, Diritto naturale e liberalismo. Dialogo o conflitto?, Torino, Giappichelli Editore, 2009, pp. 363.

55 NLT, p. 7. 
esas normas, etcétera $)^{56}$ no revisten carácter propiamente moral, sino que resultan sólo convenientes para el buen funcionamiento del derecho, aun bajo un régimen tiránico. ${ }^{57}$ Por el contrario, para Finnis, los ocho desiderata, pero en especial el que exige que los gobernantes respeten sus propias normas, son especialmente obstructivas y no promotores de los propósitos del tirano. Pero además, "la preocupación primaria de Fuller, así como de la amplia tradición de la teoría de la ley natural, es con una racionalidad y unas implicancias específicas de razonabilidad que sean completas y coherentes: es decir, con un juicio y una elección moralmente razonables". ${ }^{58}$

Esto significa que según Finnis, para Fuller y la completa tradición del derecho natural, para alcanzar la plena vigencia del gobierno del derecho no es suficiente con respetar sus aspectos procedimentales, sino que es necesaria además la presencia de un mínimo de virtud en los gobernantes y una cierta adhesión a los bienes humanos básicos. En este punto, resulta especialmente esclarecedor el trabajo de Francesco Viola citado más arriba. Pero para Finnis,

la teoría jurídica del derecho natural tiene su nota distintiva más característica en su explicación del derecho puramente positivo,

56 Los ocho desiderata del gobierno del derecho son los siguientes: (i) las reglas han de ser prospectivas, no retroactivas; (ii) deben se posibles de cumplir; (iii) tienen que promulgarse adecuadamente; (iv) han de ser claras y comprensibles para la gran mayoría; (v) deben resultar coherentes entre sí; (vi) serán relativamente estables; (vii) la aplicación de las reglas a casos particulares tiene que estar orientada por reglas como las precedentes pero generales; y (viii) las autoridades jurídicas deben aplicar las reglas coherentemente y según su tenor, así como dar cuenta del cumplimiento de esas reglas. NLNR, pp. 270 y 271.

57 La discusión en torno al fundamento y a la finalidad del rule of law ha resurgido últimamente en los trabajos de Matthew H. Kramer y de Nigel Simmonds. La posición del primero puede verse en "Once More into the Fray Challenges for Legal Positivism", 58 University of Toronto Law Fournal, Toronto, núm. 58-1, 2008; la del segundo, en Law as a Moral Idea, Oxford, Oxford University Press, 2007, cap. 3: "Evil regimes and the Rule of Law", pp. 69-111.

58 NLT, p. 8. 
el cual, aunque dependiente para su estatus jurídico del hecho de haber sido puesto por ciertas personas e instituciones, no obstante participa de la característica del derecho de conllevar, al menos presuntivamente y de modo derrotable (defeasibly), una obligación moral de cumplimiento. Acerca de estas normas de un sistema jurídico positivo, Tomás de Aquino dice que, a pesar de que ellas han de ser, y se presume que son, "derivadas del derecho natural", tienen su fuerza jurídica solo por ser parte de un determinado sistema jurídico positivo. ${ }^{59}$

Y cita aquí el conocido texto tomista de la Summa Theologiae, I-II, q. 95, a. 3, que interpreta en el sentido de que la mayor parte del derecho positivo - el obtenido por determinación de los principios del derecho natural - podría razonablemente haber sido de otra manera, pero una vez que ha sido determinado por la autoridad competente y conforme a los procedimientos establecidos, adquiere obligatoriedad moral estricta. "La normatividad moral del principio [de derecho natural] resulta replicada en las normas más específicas creadas por la determinatio, aun cuando la última no sea un inferencia directa de la primera". ${ }^{60}$

Ahora bien, esta obligación moral de obedecer al derecho puramente positivo, desde la perspectiva finnisiana, reviste un carácter presuntivo o prima facie, y se basa en el principio moral que establece que el bien común requiere que la autoridad política actúe para especificar, aplicar y reforzar algunas normas indispensables para la convivencia. Y esta obligación es prima facie, toda vez que, como se verá a continuación, puede ser suspendida, anulada o derrotada en aquellos casos en que la norma resulte gravemente injusta. "Por lo tanto - concluye Finnis - en relación con el derecho positivo establecido, la teoría del derecho natural... comparte la principal tesis de los positivistas jurídicos contemporáneos: que el derecho depende para su existencia y validez de ciertos hechos sociales". ${ }^{61}$

\footnotetext{
59 Ibidem, pp. 9 y 10.

60 Ibidem, p. 10.

61 Ibidem, p. 11.
} 


\section{V. ¿LEX INIUSTA NON EST LEX?}

Ahora bien, la obligatoriedad del derecho puramente positivo deriva fundamentalmente de su carácter autoritativo. ${ }^{62}$ Esto ha sido estudiado y desarrollado por varios autores de la Analytical furisprudence, como Hart y Raz, para quienes el tipo de razones para la acción - llamadas exclusionarias - propuestas a los sujetos actuantes por el derecho positivo se caracterizan por ser independientes de su contenido concreto, y dependientes exclusivamente de la autoridad que las crea y promulga. Estas razones excluyen - de aquí la expresión "exclusionarias" - toda otra razón, particular o de contenido, que pueda tener el sujeto para cumplir con la misma conducta prescrita; en otras palabras: el sujeto obligado debe cumplir con la conducta reglada no porque su contenido sea adecuado o correcto, sino porque está determinada y mandada por la autoridad. Hasta aquí, la teoría del derecho natural es muy similar a la propuesta por el positivismo jurídico analítico contemporáneo. Pero - y ahora comienzan las diferencias-

esta independencia de contenido de las razones autoritativas implica su obligatoriedad presuntiva. La capacidad de ser desplazada que reviste esta presunción [de obligatoriedad] está implicada en la dependencia de su fuerza perentoria... y exclusionaria de esas razones respecto de un trasfondo presupuesto de bienes y necesidades humanas básicas y de principios morales básicos y normas, un trasfondo que supone que si una razón autoritativamente proferida (positiva) entra en conflicto suficientemente claro con esas necesidades, bienes, principios o normas permanentes, su fuerza exclusionaria deviene exhausta o superada y las obligaciones positivas resultan derrotadas. ${ }^{63}$

62 En este punto, véase NLNR, pp. 231-259. Asimismo, véase: "Introduction", en Finnis, J., Collected Essays, vol. IV: Philosophy of Law, Oxford, Oxford University Press, 2011, pp. 1-9.

63 NLT, p. 11. 
Dicho en otras palabras, la obligatoriedad moral presuntiva o prima facie de las determinaciones normativas autoritativas, obligatoriedad que excluye todo otro tipo de razones para obrar, desaparece cuando la norma de que se trata atenta gravemente contra un bien humano básico - un principio del derecho natural- En ese caso, la presunción de obligatoriedad queda eliminada, y resurge la obligación - postergada anteriormente- de obrar por buenas razones morales.

En casos como el precedente, en que la aplicación de una norma resultará en una injusticia grave y evidente, esa norma no sólo pierde su obligatoriedad moral, sino —al menos en ciertos contextos discursivos - ${ }^{64}$ también su validez jurídica. Para Finnis, "si el contexto discursivo hace apropiado puntualizar su falta de normatividad para jueces y ciudadanos, se puede decir que la norma, a despecho de sus vínculos con fuentes social-fácticas, no sólo es moralmente no-directiva, sino también jurídicamente inválida". ${ }^{65}$ Esto supone la aceptación, implícitamente presente en los textos de Finnis, de una doble dimensión de la validez jurídica de las normas positivas: (i) una validez fáctico-social, que proviene del carácter autoritativo de las fuentes sociales, y (ii) una validez racional-moral, vinculada al respeto y adecuación de esas normas a los principios - morales - que prescriben la persecución, promoción, respeto y defensa social de los bienes humanos básicos en la vida social. ${ }^{66}$

Respecto del sentido relevante del principio lex iniusta non est lex ${ }^{67}$ - el derecho injusto no es derecho-, Finnis realiza algu-

64 Véase ibidem, pp. 16 y 17.

65 Ibidem, p. 17.

66 En este punto, véase, para mayores precisiones, Zambrano, P., "El derecho como razón excluyente para la acción. Un aproximación desde la teoría iusnaturalista del derecho de John Finnis", en varios autores, Razón jurídica y razón moral. Estudios sobre la valoración ética en el derecho, coord. J. Cianciardo, México, Porrúa, 2012, pp. 71-115.

67 Sobre los antecedentes y sentido de este principio, puede verse MassiniCorreas, C. I., "La máxima lex iniusta non est lex y algunas opiniones contemporáneas", en varios autores, In umbra intelligentiae. Estudios en homenaje al Prof. 
nas precisiones especialmente importantes; la primera consiste en aclarar que esa expresión es equivalente a la de Hart, "esto es derecho, pero demasiado inicuo para ser obedecido y aplicado", ya que en la primera parte de la frase se habla de "el derecho", lo que significa que la norma pertinente es, en cierto sentido y en principio, "derecho"; y en la segunda se afirma que "desde que la justicia es el verdadero objetivo de tener y respetar el derecho, esta deficiencia particular del derecho respecto de la justicia lo priva del significado decisivo que todo derecho debe tener. Se trata aquí entonces - concluye Finnis - de derecho sólo en el sentido de que ha de ser juzgado... como un sentido no-central, distorsionado o secundario de derecho". ${ }^{6}$

La segunda precisión se refiere a la necesaria aplicación al caso de la dialéctica analógica entre casos centrales (simpliciter) y casos secundarios o desviados de derecho (secundum quid); en efecto, lo que se quiere decir con la expresión analizada es que el derecho gravemente injusto no es pura y simplemente derecho, sino un caso defectivo o hasta pervertido de derecho. Pero no obstante esto, en el caso de no revestir una norma el carácter de derecho simpliciter, se puede hablar a su respecto de "derecho", pero secundum quid, es decir, en un cierto sentido: el sentido formal, correspondiente a su origen en fuentes sociales. ${ }^{69}$ Puede decirse entonces que una norma emanada legítimamente de una fuente social jurídicamente reconocida, pero que contiene prescripciones que conducirían en su aplicación a daños graves e injustificados al bien común, tiene validez social-fáctica, pero no validez racional-normativa, que es casualmente - esta última - la que genera en definitiva el deber moral de obedecer al derecho. Y esto es así, toda vez que si bien el derecho puramente positivo o positivo per $s e,{ }^{70}$ que es el

Juan C. Cruz, ed. A. L. González \& I. Zorroza, Pamplona, EUNSA, 2011, pp. 587-604.

68 NLT, p. 17.

69 Véase Tomás de Aquino, Summa Theologiae, I-II, q. 92, a. 1, ad 4.

70 Véase Casaubón, J. A. et al., Introducción al derecho - 3-Derecho, Buenos Aires, Ariel, 1981, pp. 42 y passim. 
resultado de una determinatio autoritativa, obtiene su carácter obligatorio de su origen en la autoridad, esta última recibe su índole propia, su poder legítimo, de su orientación decisiva al bien común; en definitiva, de un principio moral y no de un hecho social como, por otra parte, no puede ser de otro modo, bajo pena de caer inexorablemente en la falacia ser-deber ser. ${ }^{71}$

La tercera de las precisiones remite a una objeción, articulada originariamente por Hart, y reiterada por numerosos iuspositivistas, según la cual el principio "el derecho injusto no es derecho" tendería a desalentar o confundir la crítica moral del derecho, ya que el derecho injusto pasaría a ser automáticamente un no-derecho, es decir, no sería derecho en ningún sentido posible y por lo tanto no podría ser criticado moralmente en cuanto derecho. ${ }^{72}$ Esto aparece a primera vista como una banalidad, toda vez que una norma injusta podría perfectamente ser criticada moralmente, aunque no se la denominara "derecho". Pero por otra parte, la objeción olvida no sólo la utilización analógica del término "derecho", sino que existe un giro lingüístico habitual según el cual se dice que un profesor que no sabe no es un profesor, o que una madre que no se preocupa por sus hijos no es una madre. En realidad, con estos giros lo que se quiere decir es que no se trata de un profesor o de una madre en sentido propio y completo, sino sólo en sentido defectivo o degradado. ${ }^{73}$

En definitiva, según la interpretación finnisiana del adagio clásico lex iniusta non est lex, interpretación que aparece como la más correcta, lo que se quiere decir es que una norma jurídica grave y notoriamente injusta — no es suficiente con una injusticia leve o problemática - pierde su capacidad de obligar en

71 Véase, en este punto, Massini-Correas, G. I., La falacia de la "falacia naturalista", Mendoza, Argentina, EDIUM, 1995, passim.

72 Véase Hart, H. L. A., The Concept of Law, 2a. ed., Oxford, Oxford University Press (Clarendon Law Series), 1997, p. 209.

73 Sobre este argumento y su crítica, véase Kretzmann, N., "Lex iniusta non est lex. Laws on Trial in Aquinas's Court of Conscience", American fournal of Furisprudence, Notre Dame, núm. 33, 1988, pp. 99-122. 
conciencia, con lo que se frustra lo que se ha denominado validez racional-valorativa. Pero no obstante esto, la norma injusta puede seguir obligando, a través de una "obligación colateral" de respetar las leyes, cuando la desobediencia pueda derivar en un daño grave para el bien común. Aquí podría seguirse hablando de "derecho" respecto de esa norma, aunque sólo en sentido formal o defectivo; en ese caso, bien podría decirse que lex iniusta est (secundum quid) lex. ${ }^{74}$

\section{LA INCOHERENCIA DEL POSITIVISMO JURÍDICO}

Además de haber sistematizado de modo prácticamente completo la teoría del derecho del iusnaturalismo clásico en los términos, modos de argumentar y problemas propios de la teoría analítica del derecho, John Finnis ha dedicado varios trabajos a la crítica de las ideas morales y jurídicas contemporáneas. En esta tarea, ha dedicado numerosas y esclarecedoras páginas a la valoración y crítica del positivismo jurídico, en especial en su versión analítica. Uno de los trabajos que desarrollan esa crítica es el que fuera publicado en la Notre Dame Law Review con el título de "On the Incoherence of Legal Positivism", ${ }^{75}$ y cuya traducción castellana apareció en un volumen colectivo publicado en México en 2006. ${ }^{76}$

En ese trabajo, Finnis comienza definiendo al positivismo jurídico como "la propuesta de que el derecho estatal es, o debería ser sistemáticamente estudiado como si fuera, un conjunto de normas originadas exclusivamente en convenciones, órdenes u otros

74 Véase NLNR, pp. 363-366.

75 Finnis, J., "On the Incoherence of Legal Positivism”, Notre Dame Law Review, Notre Dame, núm. 75, 2000, pp. 1597-1611.

76 Finnis, J., "Sobre la incoherencia del positivismo jurídico" (en adelante IPJ), trad. de C. Pereira Sáez, en varios autores, Humanismo jurídico. Ensayos escogidos, ed. G. Tenorio, México, Porrúa, 2006, pp. 1-18. 
hechos sociales similares". ${ }^{77}$ A esto agrega que "tal y como fue desarrollado por Bentham, Austin y Kelsen, el positivismo jurídico era oficialmente neutral respecto de la cuestión de si hay, fuera del derecho [positivo] criterios morales cuyo carácter directivo en la deliberación (normatividad, autoridad, obligatoriedad) no es completamente explicado por ningún hecho social". ${ }^{78}$ Es decir, el positivismo jurídico consiste, en su núcleo duro y raigal, en la idea de que el derecho positivo de las comunidades políticas existe con total independencia, incompatibilidad y extrañamiento de cualquier tipo de valoración moral, de principios ético-jurídicos o de bienes humanos a perseguir. Y también en su núcleo duro supone, asimismo, el más radical escepticismo ético, ya que sólo ese escepticismo puede justificar radicalmente el extrañamiento entre la moral - que se supone incognoscible y fruto de opciones meramente subjetivas de raíz emotiva - y las normas sociales del derecho. ${ }^{79}$

Pero Finnis reconoce que, en la actualidad,

[el] positivismo jurídico excluyente - defendido hoy por filósofos del derecho como Joseph Raz - es muy diferente. A la vez que afirma que todo el derecho se basa en y es validado por fuentes fáctico-sociales - afirmación que lo constituye en positivismo jurídico excluyente - acepta también que los jueces pueden tener, y no es raro que tengan, la obligación jurídica y moral de incluir en su razonamiento judicial principios y normas que son aplicables porque, aunque no son jurídicamente válidas (porque hasta el momento no han sido puestas por ninguna fuente fáctico-social) son, o el juez en cuestión las considera, moralmente verdaderas. ${ }^{80}$

77 IPJ, p. 2 (énfasis añadido).

78 Idem.

79 En este punto, Finnis coincide con los más acérrimos positivistas: Finnis, J., "Scepticism's Self-Refutation" y "Self-Refutation Revisited", en Collected Essays: I, Reason in Action, Oxford, Oxford University Press, 2011, pp. 62-91; Bulygin, E., El positivismo jurídico, México, Fontamara, 2006, pp. 119 y passim.

80 IPJ, p. 5. 
Esto es así, según el autor australiano, porque

el derecho tiene una doble vida. Una de sus vidas... es (i) su existencia como el puro hecho de que determinadas personas han hecho esto o lo otro en el pasado... Estos hechos proporcionan su explicación del derecho de una comunidad para el "positivismo jurídico excluyente" (nótese sin embargo, que los positivistas jurídicos empiezan a abandonar, con razón, la opinión de que la teoría jurídica debe atender sólo a aquello que está puesto en las fuentes fáctico-sociales...). La otra vida del derecho - continúa Finnis - es (ii) su existencia como criterios directivos para las deliberaciones en conciencia de quienes tienen la responsabilidad de decidir (hacer justicia) según derecho. ${ }^{81}$

Un poco más adelante, luego de considerar a las disputas entre positivistas "incluyentes" y "excluyentes" como "un estéril conflicto de demarcaciones", Finnis reitera su opinión de que el derecho debe considerarse, en general, (i) como un conjunto de hechos complejos relativos a las prácticas de ciertas personas en un momento específico, y (ii) como buenas razones para la acción. ${ }^{82}$

El problema principal de los positivistas jurídicos en este punto es que, como sostiene el profesor de Oxford,

deberían reconocer (pero no lo hacen) [que] ningún hecho o conjunto de hechos, por muy complejo que sea, puede proporcionar por sí mismo una razón para actuar, menos aún un "deber" del tipo de los que podrían tener autoridad por sobre el interés propio del individuo... Ningún deber de un mero ser. Así, el positivismo, en la medida en que se enorgullece de ocuparse sólo de hechos, no puede ofrecer una comprensión adecuada, ni de las razones para la acción (los deberes), ni de la única fuente concebible de estos deberes, es decir, los verdaderos e intrínsecos valores (los bienes humanos y los primeros principios del razonamiento práctico... que nos dirigen hacia esos bienes como al-

81 Ibidem, pp. 7 y 8.

82 Véase ibidem, pp. 8 y 9. 
go-que-ha-de-procurarse, y señalan a los que le perjudica como algo-que-ha-de-evitarse). ${ }^{83}$

Por todo lo anterior, Finnis concluye que el positivismo jurídico incurre no en una, sino en varias incoherencias; la primera radica en su pretensión de justificar la obligatoriedad del derecho y el correspondiente deber moral de obedecerlo sólo a partir de ciertos hechos sociales, denominados habitualmente "fuentes sociales", que pueden ser todo lo complejos que se quiera, pero al fin y al cabo son meros hechos sociales. Finnis repite reiteradamente el principio: ningún deber a partir del [mero] ser, y los positivistas lo aceptan, aplicando el principio - incorrectamente - a las teorías del derecho natural, pero se abstienen de aplicarlo a las propias teorías iuspositivistas a las que ese principio desautoriza decisivamente.

Pero sobre todo, Finnis niega capacidad al iuspositivismo para justificar racionalmente la autoridad del derecho. Aquí el problema radica en que el significado focal de "autoridad" o "autoritativo" es el sentido moral y no meramente técnico-condicional de amenazar con un daño si no se realiza una determinada conducta. En este último sentido se está en presencia de un accionar propio de una banda de gánsteres, que exigen una "contribución" a los comerciantes de la zona bajo la amenaza de colocarle una bomba al negocio. Por el contrario, Finnis reitera varias veces que

la condición de autoritativo del derecho, en el sentido focal de "autoritativo", no es otra cosa que su sentido moral de autoritativo. Repitámoslo: la mayoría de nuestras leyes no tendrían autoridad moral de no ser leyes positivas, jurídicamente válidas. Así que su autoridad moral es también verdadera autoridad jurídica. Las leyes que, por su injusticia, carecen de la condición moral de

83 Ibidem, pp. 14 y 15. 
autoritativas, no son jurídicamente autoritativas en el sentido focal de "autoritativo". ${ }^{84}$

Dicho en otras palabras, al negar el positivismo jurídico el carácter moral del sentido focal de "autoridad", termina aceptando el carácter estrictamente jurídico de normas como las que establecían el apartheid hace pocos años en Sudáfrica, tal como se ven obligados a hacerlo, v. gr., Coleman y Leiter ${ }^{25}$ en un ejemplo citado por Finnis. Para este último autor,

en la filosofía del derecho hay un nombre para la teoría del derecho que se compromete a identificar y debatir, abierta y críticamente, los principios y exigencias morales que responden a las exigencias de las personas que deliberan de que se les muestre por qué una norma jurídica, válidamente promulgada, es obligatoria y autoritativa para ellos precisamente como derecho: este nombre es (para bien o para mal) el de "teoría del derecho natural". ${ }^{86}$

Y esto es así casualmente porque esa teoría reconoce que el sentido radical de "autoridad jurídica" tiene necesariamente una connotación ética, derivada de su ordenación constitutiva al bien humano, al menos en su significación focal. Fuera de esa ordenación, podrán darse formas degradadas de autoridad, como en el caso de los gobiernos despóticos, o corruptos, como en el ejemplo de la banda de gánsteres. Por todo ello,

el positivismo, coherentemente, no llega nunca más que a informar de las actitudes y de la concurrencia de comportamientos... [pero] no tiene nada que decir a los funcionarios o a los ciudadanos particulares que quieren juzgar si, cuándo y porqué, la autoridad y la obligatoriedad pretendidas e impuestas por aquellos que están actuan-

84 Ibidem, p. 16. Véase, además, Finnis, J., "Positivism and «Authority»", en Collected Essays, IV, cit., pp. 74-87.

85 Véase Coleman, J. L. \& Leiter, B., "Legal Positivism", en varios autores, A Companion to Philosophy of Law and Legal Theory, ed. D. Patterson, Oxford, Blackwell, 1996, pp. 241-260.

86 IPJ, p. 16. 
do como funcionarios de un sistema jurídico, y sus directrices, son de verdad razones autoritativas para su propia acción... ${ }^{87}$

Esto es así porque "razones para la acción", en su sentido focal o propio, son sólo las razones morales, ya que son las únicas que pueden propiamente aportar una razón, que no sea meramente hipotético-condicional y que tenga el sentido de ordenar razonablemente hacia el bien humano. En rigor, razones, que son aquellas por las cuales actúan los seres humanos racionales, son las que presentan un bien o dimensión de un bien como la causa final - motivo radical — de esa conducta. El positivismo jurídico está incapacitado para explicar esto coherentemente.

En definitiva, en la exposición finnisiana queda en claro que el positivismo jurídico, respecto al iusnaturalismo, es redundante, ya que reitera una de las partes constitutivas de la teoría del derecho natural: la referida a la dimensión fáctico-social del derecho, concentrándose exclusivamente en ella, y dejando de lado completamente - al menos en el positivismo originario de Bentham, Austin y Kelsen - la dimensión crítico-racional que también integra constitutivamente el derecho. Pero por ello, el positivismo no sólo es redundante respecto de la teoría iusnaturalista, sino que es esencialmente incompleto en cuanto explicación del derecho. El iusfilósofo germano-argentino Werner Goldschmidt sostenía que el positivismo jurídico explicaba sólo el 33,33 por ciento de la realidad jurídica; desde la perspectiva finnisiana explica un poco más: el 50 por ciento, pero siempre resulta radicalmente incompleto en cuanto explicación de la realidad jurídica.

\section{CONCLUSIONES: DERECHO NATURAL Y TEORÍA DEL DERECHO}

Luego de la anterior reseña del pensamiento de John Finnis acerca de los lineamientos generales de una teoría del derecho iusnatura-

87 Ibidem, pp. 17 y 18. 
lista y de la incapacidad constitutiva del positivismo jurídico para explicar de modo completo y coherente el fenómeno jurídico, conviene sintetizar los principales resultados que pueden extraerse de esas ideas. Éstos son los siguientes:

a) El modo de aproximación a la realidad jurídica propuesto por Finnis tiene dos características fundamentales: es práctico y analógico; el approach práctico hace posible la captación del sentido de las realidades humano-prácticas, en especial las jurídicas, en cuanto hace patente los fines, valores y bienes a los que se orienta y que le otorgan justificación racional; sin esta perspectiva, afirma Finnis, no sería siquiera posible distinguir las realidades jurídicas de las que no lo son; y el carácter analógico del conocimiento jurídico hace posible la comprensión integral de una realidad tan compleja como la jurídica, en la que sus diferentes elementos son jurídicos en diferentes grados, existiendo casos centrales y secundarios, deficientes o corruptos; en definitiva, esta perspectiva práctico-analógica es la más adecuada para una comprensión integral y de sentido de la realidad del derecho.

b) En la realidad múltiple y compleja del derecho es posible distinguir dos dimensiones centrales o elementos complementarios que lo constituyen: (i) la dimensión fáctico-social, que incluye las fuentes sociales del derecho, las instituciones autoritativas que lo configuran o aplican, los actos de fuerza que respaldan su cumplimiento, etcétera, y (ii) la dimensión racional-valorativa, que se integra con las deliberaciones, juicios, valoraciones, intenciones, imperativos y calificaciones que ponen en marcha al derecho: lo crean, aplican y justifican racionalmente, proveyendo a los sujetos jurídicos de razones para el obrar, ${ }^{88}$ que es el modo como

88 Sobre la noción de razones para la acción, véase Boyle, J., "Reasons for Action: Evaluative Cognitions that Underlie Motivations", en The American fournal of Furisprudence, Notre Dame-Indiana, núm. 46, 2001, pp. 177-197. 
actúan propiamente seres racionales como los humanos, ${ }^{89}$ esta "naturaleza dual" o "doble vida" del derecho conduce a la postulación de una validez doble para el derecho: (i) la fáctico-social, u originaria, o causal, o fontal, que hace referencia al conjunto de hechos sociales realizados o legitimados por una autoridad, hechos que producen, aplican o ejecutan normas sociales; es decir, se trata de la validez que arraiga en las "fuentes sociales", y (ii) la racional-valorativa, o finalista, o de sentido, que remite a los criterios, valores, bienes y razones que justifican el obrar humano jurídico; sin esta segunda dimensión de la validez, el derecho se reduce a un mero hecho o hecho bruto sin capacidad de generar razones para la acción y regular humanamente a los seres humanos, racionales por definición.

c) La validez racional-valorativa es la que justifica en definitiva el deber de obediencia al derecho positivo, en razón, principalmente, de la necesidad de la coordinación y regulación de las conductas para el logro del bien común social, que no es sino el mejor bien personal de todos los sujetos jurídicos; en este sentido, las normas provenientes de las fuentes sociales generan un deber estricto - deber ético - de conformidad y acatamiento, pero este deber tiene el carácter de prima facie o presuntivo, en razón de que, en caso de injusticia severa y palmaria de una norma, ésta resultará suspendida o anulada - derrotada, les gusta decir a los analíticos - y recobrarán su vigencia inmediata los principios racionales del derecho natural.

d) Es también esta doble validez la que explica el sentido del principio tradicional lex iniusta non est lex, unida al carácter analógico del concepto y del término "derecho"; las normas grave y palmariamente injustas carecen de validez racional-valorativa, y por lo tanto no conviene considerar-

89 En este punto, véase Murphy, M. C., Philosophy of Law, Malden-OxfordCarlton, 2007, pp. 39 y passim; del mismo autor, Natural Law in Furisprudence and Politics, Nueva York, Cambridge University Press, 2009, p. 4 y passim. 
las como derecho en su sentido pleno o significación focal, sino sólo en sentido secundario: en cuanto degradaciones o corrupciones del derecho integral; de este modo, sostiene Finnis, una norma injusta será "derecho" en un cierto sentido, sólo formal o causal-originario, pero no lo será en el sentido propio y formal o focal, de una directiva efectivamente ordenada al bien humano común. ${ }^{90}$

e) El positivismo jurídico, por su parte, resulta — según Finnisradicalmente incompleto e incoherente: incompleto, porque deja sin explicar toda una dimensión - la más radicalmente humana- del fenómeno jurídico: la dimensión racional-valorativa; e incoherente, ya que su explicación de la autoridad del derecho y de las razones para la acción que esta autoridad genera no se refiere propiamente a razones de carácter deóntico, sino sólo a motivos técnico-condicionales para evitar daños previsibles, con lo que el Estado queda reducido estrictamente a una "banda de gánsteres mejor organizada", según el conocido dictum atribuido a Max Weber; y los sujetos jurídicos dejan de ser considerados propiamente como seres humanos que se dirigen racionalmente, para reducirse a animales superiores que reaccionan instintivamente frente a estímulos desagradables; y además, con su pretensión de derivar un deber de obediencia al derecho de meros hechos sociales, incurre claramente en la conocida falacia ser-deber ser, que invalida toda su argumentación; todo esto, por supuesto, se refiere al positivismo en sus versiones clásicas: el neopositivismo, "incluyente" o no, debe ser objeto de otras consideraciones, en especial referidas a si se trata propiamente de un "positivismo".

f) La versión finnisiana de la teoría del derecho iusnaturalista tiene el enorme mérito de haber reformulado, desarrollado y actualizado la teoría clásica del derecho natural, dán-

90 Sobre la noción de bien común, resulta especialmente ilustrativo el libro de Keys, M. M., Aquinas, Aristotle, and the Promise of the Common Good, CambridgeNew York, Cambridge University Press, 2006. 
dole la estructura y el estilo argumentativo de las propuestas contemporáneas - en especial analíticas - de filosofía jurídica; de este modo, el iusnaturalismo pudo entrar nuevamente en el debate iusfilosófico contemporáneo, del que había sido desplazado, en parte por la intolerancia del positivismo, hegemónico durante un siglo, pero también en parte por su propia renuencia a la actualización de su lenguaje y modalidades argumentativas; es cierto que varias de las tesis finnisianas, en especial en el campo de la teoría ética, suponen interpretaciones discutibles de los textos de la tradición de la ley natural: estas tesis deberán discutirse en su sede propia, pero en lo que respecta a la teoría del derecho, su contribución resulta de un valor intelectual notable que enriquece y desarrolla los postulados de la valiosa tradición de la teoría del derecho natural y significa una contribución de especial relevancia para la filosofía jurídica contemporánea.

g) Finalmente, conviene terminar con unas palabras acerca de la filiación tomista de la obra de Finnis acerca del derecho, lo cual es importante, ya que varios autores han negado a este autor toda posibilidad de enraizamiento con la obra del Aquinate, y aun han llegado a decir - el autor de estas líneas lo escuchó personalmente- que no podía considerarse a Finnis como católico; en este punto conviene traer a colación la opinión del mismo Finnis, quien en su trabajo "Practical Reason's Foundations" escribe que

no es cuestión de aceptar la explicación de Tomás de Aquino simplemente porque es la suya, o porque incorpora la de Aristóteles (y Platón), o bien porque se ajusta a algunos de los principales aspectos de los hábitos de pensamiento de los juristas. Todo en ella ha sido cuestionado, y para ser reutilizado (si lo merece y en la medida en que lo merezca), ha de ser analizado a la luz de esos cuestionamientos y críticas. ${ }^{91}$

91 Finnis, J., "Practical Reason's Foundations", en Collected Essays, I: Reason in Action, Oxford, Oxford University Press, 2011, p. 22 (hay traducción castellana: 
Por lo tanto, queda claro que la perspectiva adoptada por Finnis respecto del pensamiento del Aquinate es la de receptarlo a través de $-\mathrm{y}$ teniendo en cuenta - las críticas que se le han efectuado, y buscando los argumentos y reformulaciones que hagan posible superarlas. Esta especial perspectiva de abordaje debe ser especialmente considerada cuando se estudian - y critican - las opiniones del profesor oxoniense.

\author{
Carlos I. MASSINI-CORREAS \\ Universidad de Mendoza-Universidad Austral
}

"Revisando los fundamentos de la razón práctica", en Persona Ë Derecho, trad. de C. I. Massini-Correas, Pamplona, núm. 64, 2011, pp. 15-42). En un sentido similar, Guido Soaje Ramos escribió con acierto que "un tomismo vivo, según entiendo, supone en el nivel de las convicciones fundamentales, que opus philosophicum semper perfectibile y que, en consecuencia, no se trata sólo de poseer, con la mayor fidelidad posible, un rico patrimonio heredado"; Soaje Ramos, G., "Ética y antropología filosófica", en Ethos, Buenos Aires, núms. 16-18, 19881990, pp. 53 y 54. 


\section{¿QUÉ ES LA FILOSOFÍA DEL DEREGHO?*}

Como la ética y la filosofía política, las partes de la filosofía de las cuales depende de manera directa, la filosofía del derecho pertenece a la filosofía de la razón práctica. La razón práctica, y con ello la filosofía de la razón práctica (filosófica porque considera los problemas de la razón práctica en su completa universalidad) procura hacer razonables las deliberaciones y elecciones a través de las cuales las personas dan forma a sus acciones libremente escogidas y de ese modo también se configuran a sí mismas y a sus comunidades. La ética considera tales problemas en la forma en que ellos colocan a todo individuo, sin excepción, ante la situación de elegir una conducta significativa (acción o inacción), elección que, dando forma al mundo, también modelará su propio carácter. La filosofía política (comprendiendo - aunque sin absorberla - a la filosofía de lo doméstico y de lo familiar) considera los problemas que se nos plantean a cada uno de nosotros precisamente en la medida en que necesitamos actuar en conjunto con otros miembros de nuestras comunidades, como miembros o líderes cuyas elecciones son elecciones para la comunidad a cuyas acciones intentamos que nuestras acciones contribuyan. La filosofia del derecho (filosofia jurídica*** amplía y especifica la filosofía política al considerar precisamente en qué medida las elecciones hechas hoy para el futuro de la propia comunidad política deberían estar determinadas o configuradas por elecciones hechas y actos realizados en el pasado, en la forma de contratos, testamentos, Constituciones, actos legislativos, costumbres, decisiones judiciales y cosas por el estilo.

* Traducción de Carlos I. Massini-Correas.

** Finnis utiliza aquí las expresiones philosophy of law (filosofía del derecho) y legal philosophy (filosofía jurídica) como sinónimas. En el texto así las hemos traducido (atribuyendo también la traducción "filosofía jurídica" para la expresión philosophy of laws): $\mathcal{N}$. del $T$. 
Tal cuestión es en sí misma el tema de varios "principios generales del derecho reconocidos por las naciones civilizadas", ${ }^{1}$ principios fundamentales que toman parte directamente en las determinaciones necesarias. La filosofía del derecho identifica los fundamentos para aceptar tales principios como apropiados (justos) y autoritativos, junto con los fundamentos para juzgar

1 Estatuto de la Corte Internacional de Justicia, artículo 38 (1) (d). En $\mathrm{Na}$ tural Law and Natural Rights (1980/2011), [NLNR] yo presento una breve lista:

"Comenzando con... las máximas de segundo orden que favorecen la continuidad en los asuntos humanos - i. e. que favorecen el bien del orden diacrónico, en cuanto distinto del bien de una situación final futura-, podemos encontrar una serie de principios de segundo orden relacionados que incluyen el principio de estabilidad, pero que van cada vez más allá de él para incorporar nuevos principios o valores. En cada caso ellos están disponibles en la forma de primer orden para guiar al legislador. La forma en prosa requiere aquí una exposición lineal que simplifica excesivamente y que disfraza sus interrelaciones: i) la privación forzosa de derechos de propiedad ha de ser compensada por el damnum emergens (daño emergente), si no lo es también por el lucrum cessans (pérdida de beneficios esperados); $i$ ) no hay responsabilidad por daños involuntarios, sin culpa; iii) no hay responsabilidad penal sin mens rea; iv) nemo contra factum proprium venire potest (estoppel o prohibición de ir contra los actos propios); v) no hay protección judicial para quien invoca su propio delito (quien procura equidad debe obrar equitativamente); vi) no hay amparo para el abuso de derecho; vii) el fraude lo destruye todo (fraud unravels everything [frase célebre de Lord Denning, MR., en "Lazarus Estate Limited v. Beasley", 1956, 1 QB 702, $712-\mathcal{N}$. del T.- ]); viii) los beneficios recibidos sin justificación y a expensas de otro deben ser restituidos; $i x$ ) pacta sunt servanda (los contratos deben ser cumplidos); $x$ ) hay relativa libertad para cambiar por acuerdo los modelos (patterns) existentes de relaciones jurídicas; $x i$ ) al determinar los efectos jurídicos de pretendidos actos jurídicos, el débil debe ser protegido de su debilidad; xii) las disputas no han de ser resueltas sin dar a ambas partes una oportunidad de ser oídas; xiii) nadie puede ser juez en causa propia.

Estos "principios generales del derecho" son ciertamente principios. Esto quiere decir que, más que exigir, ellos justifican reglas y determinaciones particulares, y que en su aplicación a las circunstancias concretas están delimitados por otros principios similares. Cualquiera de ellos, además, ocasionalmente puede ser desplazado (lo que no es lo mismo que violado, modificado o derogado) por otros componentes importantes del bien común, otros principios de justicia. Tampoco ha de olvidarse que existen normas de justicia que nunca pueden ser derogadas o desplazadas, y que se corresponden con los derechos humanos absolutos. 
apropiada y autoritativamente los diferentes tipos de actos de creación del derecho privado y público y de afectación de derechos (actos jurídicos) mencionados más arriba. Así como la ética busca la realización (fulfillment) de todas las formas básicas de bien humano, en la medida en que las elecciones y acciones puedan conducir, o ser contrarias, a tal realización, y la filosofía política se ocupa de la incidencia de las elecciones y acciones sobre el bien común de una comunidad política - sobre la realización y los derechos humanos de todos sus miembros-, la filosofía del derecho indaga sobre los fundamentos para aceptar la justicia de los principios básicos del derecho y la autoridad (authoritativeness) de los actos jurídicos privados y públicos en la incidencia de tales principios y actos sobre el bien común. Este bien común se extiende en continuidad significativa desde el pasado en el cual los miembros de la comunidad eligieron aquellos actos (como alternativas opuestas, razonables e irrazonables) hasta el presente, que tales actos pretenden precisamente determinar y que de modo similar pueden ahora determinar (en la debida medida) la futura realización de la misma comunidad históricamente extendida y de sus miembros.

El alcance de la filosofía del derecho es de este modo el alcance de la nomothetike ${ }^{2}$ de Aristóteles y de la legis positio ${ }^{3}$ de Santo Tomás de Aquino, que él entendía como extendiéndose más allá de la filosofía - la ciencia práctica-, cuya verdad filosófica le permite a uno participar en la elaboración de la Constitución y de la legislación, incluyendo también (subordinada al constituyente y al legislador en cuanto tales) el arte y la sabiduría que necesita el juez, para no mencionar asimismo el entendimiento cívico, la obediencia al derecho y la lealtad crítica del buen ciudadano. $^{4}$

2 Nicomachean Ethics [NE], X.14: 1181 b20.

3 Aquinas, In Eth., X.16 nn. 11-17; III Sent. d. 33 q. 3 a. 1 sol. 4c.

4 Aquinas, III Sent. d. 33 q. 3 a. 4 sol. 6c: "la justicia... está en el juez así como también en el que legisla, y está en los otros así como en lo regulado. Mas al juez corresponden dos cosas: una es que se realice la igualdad entre las 
Para su comprensión de los bienes comunes a todas las personas, incluyendo todo lo que pueda ser pensado filosóficamente acerca de la realización humana, la filosofía jurídica apela directamente a la ética. Tal comprensión toma la forma de los primeros principios de la razón práctica, dirigiéndonos a cada uno de nosotros a todos los bienes humanos básicos (cada uno un aspecto irreductible del florecimiento humano), y de los principios específicamente morales que nos dirigen a elegir y actuar razonablemente, enfrentados como lo estamos no con uno sino con muchos bienes, no con una forma de realizar cada bien sino con varias, y no con una persona en el cual esos bienes pueden ser realizados, respetados u ofendidos, sino con muchas. Para su comprensión del bien común de las familias, de otras asociaciones de la sociedad civil y del Estado, la filosofía jurídica se apoya directamente en la filosofía política. Esta comprensión incluye lo que puede decirse en general, sobre la base de una amplia experiencia humana, acerca de las condiciones fácticas de coexistencia y cooperación en la vida política y en la acción colectiva, condiciones que el poder estatal y la legislación necesitan considerar plenamente y que por eso son parte de la materia de la filosofía política y jurídica.

Un ejemplo elemental de tales condiciones es el hecho de que la unanimidad acerca de las formas específicas de la vida en común y de la acción común no resulta prácticamente alcanzable o disponible como fuente de cooperación en la vida de una comunidad política. Ésta, en la práctica, necesita y justifica el concepto y las instituciones de la autoridad, considerada como justificación, si bien presunta y susceptible de ser dejada de lado (defeasible), de la obligación de cumplir con las directivas autoritativas

personas, y para eso existe la ley positiva; otra es castigar a los que ocasionan desigualdad, y para eso es la justicia retributiva" [iustitia... est in iudice sicut in regulante, et est in aliissicut in regulatis. Ad iudicem autem duo pertinent: unum est quod aequalitates in aliis faciat, et ad hoc est legis positiva; aliud est ut inaequalitatem facientes puniat, et ad hoc est vindicativa]. 
(legislativas, judiciales o ejecutivas, etcétera). ${ }^{5} \mathrm{O}$, una vez más, datos elementales acerca de las limitaciones de la previsión humana justifican la institución o práctica que nosotros llamamos equidad (apartamiento de la letra de la ley establecida en interés de sus propósitos subyacentes y de la justicia).

Sobre estas bases, la filosofía del derecho extiende la ética y la filosofía política al campo de lo específicamente jurídico. Tal campo, como he dicho más arriba, se caracteriza porque los fundamentos para las decisiones presentes acerca del futuro se arraigan en hechos del pasado. Esos hechos son las fuentes del derecho, ya sea en legislación escrita o en la práctica y costumbres de los jueces o de otros, o en doctrina disponible de juristas académicos. Las fuentes son entendidas en el sentido de ofrecer un conjunto de proposiciones normativas (acerca de poderes y obligaciones) que a su turno son interpretadas de modo que sean coherentes en un sentido más rico y exigente que la mera evitación de contradicciones directas al momento de su especificación completa como normas de elección y de acción. Cada uno de tales conjuntos de proposiciones — "el sistema jurídico", "la ley del país", "nuestro derecho", etcétera - es considerado aplicable, en principio en su totalidad, a cada persona y hecho dentro de su jurisdicción. Y se considera que la validez de cada proposición en el sistema jurídico es controlada por otras proposiciones más allá del conjunto y es una precondición para su aplicabilidad a las personas y hechos en particular.

Conceptos tales como jurisdicción y validez no son, en su sustancia, desconocidos para la filosofía política; ya están implícitos en la discusión de Aristóteles sobre la deseabilidad (desirability) del Estado de derecho (Rechtsstaat). ${ }^{6}$ Pero ellos quedaron más bien implícitos e inarticulados hasta que la filosofía del derecho los tomó del discurso jurídico. Lo hizo precisamente para explicar

5 Véase "Positivism and "Authority»", ensayo 4 en The Collected Essays of John Finnis, Oxford University Press, 201 1, vol. IV [CEJF, IV]; Natural Law Natural Rights, capítulo IX.

6 Véase especialmente: Politica, III, 16: 1287a. 
por qué cada sistema jurídico desarrolla apropiadamente estos (y otros) conceptos como instrumentos técnicos para asegurar que las reglas e instituciones de un sistema jurídico puedan hacer con relativa frecuencia lo que el razonamiento filosófico y la deliberación política como tales frecuentemente no pueden hacer, es decir, proporcionar una respuesta inequívoca a algunas cuestiones relativamente específicas acerca de cuál será la elección y la conducta correctas en una específica y ciertamente particular situación. La capacidad del derecho positivo - el conjunto de proposiciones de derecho de nuestro sistema jurídico- de proporcionar tales respuestas determinadas es un modo primario a través del cual el mismo conecta pasado, presente y futuro de la comunidad, confiere efecto a las legítimas expectativas o, al menos, a derechos legalmente adquiridos, incluyendo derechos de propiedad, contractuales y cuasicontractuales, fideicomisos, derechos a la compensación y restitución, etcétera, y así hace posible una vasta expansión de la vida económica y cultural, y elecciones familiares e individuales de conducta y vocación relativamente seguras y autónomas. Todo esto es parte de la filosofía política y del arte político, una parte tan extendida y especializada como para merecer su distinto (¡no separado!) lugar y nombre: filosofía del derecho.

\section{JURISPRUDENCIA O FILOSOFÍA DEL DERECHO}

Si seguimos el inequívoco y saludable ejemplo de Tomás de Aquino, no haremos distinción entre lex y ius cuando el último término significa lo que significa en, por ejemplo, las frases ius civile o ius naturale - frases empleadas por Santo Tomás de manera enteramente sinónima de lex civilis y lex naturalis, respectivamente-. ${ }^{7}$ Por eso es que "jurisprudencia" (jurisprudence) y "filosofía del derecho" (philosophy of law) pueden con propiedad ser usadas enteramente

7 Véase Finnis, Aquinas: Moral, Political and Legal Theory, Oxford University Press, 1998 [Aquinas], 135. 
como sinónimas, tal como es usual en los países de habla inglesa. Por supuesto que ambos elementos etimológicos del término "jurisprudencia" ejercen alguna fuerza gravitacional (lejos de ser irresistible) respecto de los relativamente más particularizados, menos universales y con ello menos filosóficos. ${ }^{8}$ Pero así como Tomás de Aquino trata la legis positio para designar no sólo el altamente particular asunto de dictar leyes, sino también el nivel supremo de politica, la teoría/filosofía política, y considera a la política en cuanto filosofía al mismo nivel que la philosophia moralis - más aún, como una rama o especie, con suprema dignidad, de la philosophia moralis - 9 , del mismo modo también podemos considerar correctamente a la jurisprudencia y a la filosofía del derecho como extendiéndose desde la exploración de las técnicas específicamente jurídicas (investigando críticamente aquellas fundamentaciones racionales técnicas según consideraciones de florecimiento humano y corrección moral) hasta los más elevados y amplios principios y demás consideraciones de la teoría moral y política.

\section{TEORÍAS DEL DERECHO NATURAL Y POSITIVISMO}

En tanto que "derecho natural", en el presente contexto, significa lo mismo que "los principios y standards normativos de la ética y la política" (o "filosofía política normativa"), todo lo dicho hasta aquí en este artículo es una pieza de teoría del derecho natural. Tal teoría contiene de manera autónoma, como uno de sus ele-

8 Pero tal fuerza no es irresistible, como lo podemos ver en las frases de apertura (de Ulpiano) de las Institutas de Justiniano, frases que siguen siendo acertadas: "Iustitia est constans et perpetua voluntas ius suum cuique tribuere. Iurisprudentia est divinarum at que humanarum rerum notitia, iusti atque iniusti scientia".

9 In Eth., prol. (I.1 n. 6) y I. 2 nn. 1-12 (en que llama a las otras ramas ética (monástica) y filosofía doméstica (oeconomica); Aquinas, 114-5. Et indeest, quod moralis philosophia in tres partes dividitur. Quarum prima considerat operations unius hominis ordinatas ad finem, quae vocatur monastica. Secunda autem considerat operations multitudinis domesticae, quae vocatur oeconomica. Tertia autem considerat operations multitudinis civilis, qua evocatur politica. 
mentos intrínsecos, la tesis de que las sociedades humanas necesitan el derecho positivo, y una descripción de varias características necesarias del derecho, de los sistemas jurídicos y del Estado de derecho. La teoría del derecho natural, en este contexto, sólo es otro nombre de la filosofía jurídica. Ella es plenamente positivista, si por tal se entiende que, apropiadamente desarrollada, produce una descripción suficiente y completa del concepto, instituciones características y fuentes del derecho positivo y del Estado de derecho. No existe un lugar apropiado para un positivismo fuera de la teoría del derecho natural. ${ }^{10}$

El (ius)positivismo que es autoconcebido como opuesto de algún modo a la teoría del derecho natural es (sólo en la medida en que el mismo sostiene aquella auto-identificación $e$ incluye tesis que difieren de las de la teoría del derecho natural ${ }^{11}$ un conjunto

10 Véase, además, CEJF, IV, ensayos 1, 5 y 7; y Finnis, "Natural Law Theory: Its Past and Its Present", en Marmor (ed.), Routledge Companion to the Philosophy of Law, 2012. Por supuesto que hay lugar para cuidadosas exposiciones doctrinarias histórica y estrictamente descriptivas de sistemas jurídicos particulares. Pero las mismas no tienen el carácter de teoría o filosofía.

11 Obsérvese que no es claro en qué medida estas dos características pueden encontrarse en teorías o posturas teoréticas como las de John Gardner y Leslie Green, o incluso (al menos gran parte del tiempo) de Joseph Raz. Es que estos teóricos, cada uno a su manera, aceptan que la filosofía del derecho contiene legítimamente tesis — quizás numerosas - que no pueden ser llamadas positivistas y son tesis morales y/o de filosofía moral; cada uno considera positivista sólo la restringida tesis de que el derecho positivo sólo se identifica por referencia a las fuentes fácticas sociales, una tesis explícitamente compatible con la posición de que los jueces legítimamente pueden, y con frecuencia deben, razonar "conforme a derecho", un derecho y forma de (dice) "razonamiento jurídico" que incluye (además del derecho positivo identificable a partir de las fuentes fácticas sociales) también principios morales (incluso, según Raz, si no hay derecho positivo que siquiera tácitamente autorice tal recurso judicial a principios morales): véanse los pasajes de Green ya citados (ibidem, p. 247) de su artículo exponiendo y defendiendo el positivismo jurídico:

"El argumento valorativo es, por supuesto, central para la filosofía del derecho en general. Ningún filósofo jurídico puede ser sólo un positivista (legal positivist). Una teoría completa del derecho exige además una exposición de qué clases de cosas podrían posiblemente contar como los méritos de la ley (¿la ley debe ser eficiente o elegante, así como justa?); o de qué rol debería jugar el 
de teorías más o menos confusas y arbitrariamente recortadas, pensadas en algunos casos sobre la base de graves malentendidos $^{12}$ acerca de la tradición de la teoría del derecho natural y de algunos de sus teoremas, y en otros casos simplemente como la expresión del escepticismo moral (negación de que exista alguna proposición verdadera sobre el bien humano y la corrección moral) - y en algunos casos, tal como en Kelsen, sobre ambas bases - Ninguna de estas bases es defendible. Los malentendidos deben ser superados prestando atención a la evidencia y leyendo textos clásicos con algún cuidado y atención. El escepticismo sobre la verdad práctica puede aparecer a primera vista como una base más plausible para el positivismo jurídico. Pero, dejando de lado las respuestas que podrían darse con toda corrección contra las tesis y argumentos escépticos en ética (o "metaética"), ${ }^{13}$ ha de reconocerse que si el escepticismo es correcto, la filosofía del derecho no existe. A lo sumo puede haber exposiciones históricas (siguiendo los relatos de competentes prácticos del derecho) de sistemas normativos - aceptados o impuestos - de comunidades particulares autointerpretados como jurídicos, y de sistemas análogos a aquéllos. La historia o conjunto de historias podría ser complementada con alguna clase de estadística acerca de la frecuencia o "tipicidad". Pero si no puede decirse nada verdadero

derecho en la adjudicación (¿debe aplicarse siempre la ley válida?); o de qué pretensión tiene la ley sobre nuestra obediencia (¿existe un deber de obedecer?); y además, de las cuestiones centrales acerca de qué leyes deberíamos tener y si deberíamos tener alguna ley. El positivismo jurídico no aspira a responder estas cuestiones, a pesar de que su pretensión de que la existencia y contenido de las leyes depende exclusivamente de hechos sociales es lo que les da su forma".

Green, "Legal Positivism", The Stanford Encyclopedia of Philosophy, Spring 2003 edn; http://plato.stanford.edu/archives/spr2003/entries/legal-positivism.

12 Véase, por ejemplo, CEJF, IV, 7-8, 105, 182-6 (las páginas mencionadas en último término son la parte principal del ensayo "The Truth in Legal Positivism"); NLNR, 363-6.

13 Véase v. gr., Finnis, Fundamentals of Ethics, Oxford University Press \& Georgetown University Press, 1983, cap. II; CEJF, I, ensayos 1 a 6; Dworkin, Ronald, Fustice for Hedgehogs, Harvard University Press, 2011. 
acerca del bien humano, no hay nada que pensar o decir sobre normatividad, autoridad, obligación, validez y conceptos similares, pues todos ellos obtienen su sentido a partir de la presuposición de que la razón práctica puede distinguir entre verdadero y falso, buena razón y falta de razón, y así sucesivamente.

En cuanto a la atención a los hechos, que los positivistas creen que es una virtud de su método, ella está plenamente presente y operativa en cualquier filosofía del derecho adecuada (como la teoría del derecho natural), pues la razón práctica avanza en la deliberación hacia la elección (sea en concreto, o más universal y abstractamente, "filosóficamente"), y lo hace así por medio del uso no sólo de premisas normativas sobre el bien y lo correcto, sino también, indispensablemente, de premisas fácticas acerca de las condiciones en las cuales el bien puede ser alcanzado o podría ser dañado. La verdad de tales premisas ha de obtenerse a través de una rigurosa atención a los hechos, la experiencia, lo típico, lo probable, lo física, biológica o psicológicamente posible, etcétera.

En síntesis: la filosofía del derecho se estudia mejor sin dependencia de aquel equívoco calificado como "positivista". ¿Deberíamos rechazar también el rótulo de "teoría del derecho natural"? Cualquier teoría o filosofía del derecho aceptable necesitará atender a dos amplias clases de principio norma y estándar: aquellos aplicables por las personas con razonabilidad práctica sólo porque son estándares elegidos o establecidos fácticamente de otra manera por elecciones pasadas de su comunidad, y aquellos que son aplicables hayan sido o no elegidos o ratificados. Para éstos la historia de nuestra civilización ha adoptado el nombre "derecho natural". La adopción puede ser rastreada hasta la lucha de Platón con la teoría sofista de que la fortaleza y la astucia más o menos egoístas naturalmente - y por así decirlo, correcta y razonablemente - prevalecen en la deliberación humana. La brillante recuperación platónica de lo "correcto por naturaleza" de este error sofístico ${ }^{14}$ ha sido decisiva para nuestro vocabulario,

14 "Natural Law Theory...", n. 10 supra. 
haciendo su camino a través de Aristóteles, los estoicos, Cicerón, San Pablo, Gayo y Tomás de Aquino y sus sucesores hasta la Carta de las Naciones Unidas ${ }^{15}$ y la actualidad. No hay ninguna simetría de inutilidad (unserviceability) entre los rótulos "positivismo" y "teoría del derecho natural", a pesar de que el segundo, seguramente, padece malentendidos tan graves como los de los sofistas, complicados además por una larga secuencia civilizacional de reversiones, crecimientos y desechos cuasi-filosóficos (quasi-philosophical flotsam and jetsam).

\section{LA NORMATIVIDAD JURÍDICA COMO DISTINTA DE LA NORMATIVIDAD MORAL}

Una razón importante para querer introducir el derecho positivo y el Estado de derecho es la de resolver disputas dentro de una comunidad política acerca de lo que la moral (especialmente la justicia) exige, recomienda o permite. Existe así una buena razón para introducir una manera de pensar - llamémosla pensamiento jurídico (legal thinking) - en la cual (dentro de límites indefinidos pero importantes) el mero hecho de que una persona o cuerpo de personas autorizado jurídicamente ("constitucionalmente") haya pronunciado su determinatio ${ }^{16}$ acerca de una cuestión discutida o discutible, es considerado como fundamento suficiente para afirmar la validez jurídica de la determinatio y de su producto proposicional (regla, juicio, etcétera). En esta manera de pensar, las cuestiones de la justicia o injusticia de la determinatio, una vez que ésta ha sido hecha, son empujadas a los márgenes del ámbito del derecho. Sólo cuando los extremos morales son alcanzados, las cuestiones de justicia y moralidad vuelven a ser relevantes. Este hablar de "validez"

15 Artículo 51: "Aucune disposition de la presente Charte ne porte atteinte au droit naturel de légitime defense...". Artículo 111: "La presente Carta, de la cual los textos chino, francés, ruso, inglés y español son igualmente auténticos...”.

16 Véase NLNR, 284-6, 294-5, 380; CEJF, IV en pp. 2, 12, 123, 128, 131-2, 149, 161, 179-83, y ensayo 13. 
puede - en mayor o menor medida - ser enteramente reservado al discurso jurídico intrasistemático (derecho positivo), y adoptado para implicar una obligatoriedad no moral sino jurídica (una obligatoriedad que no ha de ser entendida de manera reduccionista como mera exposición [liability] a pena o castigo). ${ }^{17}$

La teoría del derecho natural no discute - más bien promueve - la distinción o bifurcación entre validez (y obligatoriedad) (jurídica) intrasistemática y validez (y obligatoriedad) en sentido moral. ${ }^{18}$ Por cierto no es irrazonable ver que tal distinción funciona en el famoso dicho "una ley injusta no es derecho". Tal modo de hablar no es autocontradictorio, paradójico o siquiera objetable: "un amigo mentiroso no es un amigo"; "un argumento lógicamente inválido no es ningún argumento"; "una medicina de curandero no es una medicina". Así, también en el famoso dicho o teorema: "ley injusta" (unjust law, lex iniusta) se habla de una regla u orden jurídica intrasistemáticamente válida, ${ }^{19}$ y "no derecho" (not law, non lex) significa que, habiendo sido transgredidos los límites morales, esa misma ley carece de validez (en cuanto ley) en sentido moral (es decir, legitimidad) y así, en cuanto tal, ${ }^{20}$ carece de obligatoriedad moral.

Cambios de significado de este tipo fueron estudiados de cerca por Aristóteles en conexión con su exposición de los tipos de equívoco u homonimia, y de lo que ahora podríamos llamar

17 En tal contexto discursivo, uno podría optar por usar "legitimidad" para significar relevancia moral, fundamentando obligatoriedad moral. Pero "legitimidad" tampoco está libre de ambigüedad, desde que algunos escritores en la teoría jurídica contemporánea parecen tratarla, quizá, como sinónimo de validez (puramente jurídica).

18 NLNR, en pp. 314-20.

19 Por supuesto que el hablante podría alternativamente estar queriendo predicar la injusticia de ciertas creencias y prácticas - observables como hechos sociales de reconocimiento de ciertos actos y hechos como leyes - sin querer postular validez jurídica ni siquiera en un sentido técnico, restringido y amoral.

20 Cumplir con ella en alguna medida puede seguir siendo moralmente obligatorio, a causa de los efectos colaterales del (público) incumplimiento: NLNR, p. 361. 
predicación análoga. Puede decirse que un término es análogo cuando su significado cambia más o menos sistemáticamente según el contexto. El tipo de analogía más relevante en el campo de los asuntos humanos es lo que Aristóteles llamaba homonimia pros hen. Ésta existe cuando los varios significados relevantes de una palabra son todos referibles a un significado (o sentido o uso) focal, un significado que distingue un caso primario o central del tipo de realidad o materia bajo consideración - focal y central en algún contexto de discurso o indagación- Los sentidos no focales y los casos no centrales pueden ser considerados como secundarios por cuanto ellos son casos inmaduros o desviados, o de alguna otra manera son concreciones o aspectos falsificados de la realidad, al menos cuando se los considera desde algún punto de vista adecuado o para algún propósito teórico o práctico apropiado. Todos los teóricos del derecho que se identifican a sí mismos como positivistas - es decir, como contrarios a lo que ellos piensan que es la teoría del derecho natural - han prestado demasiada poca atención a este aspecto de nuestro lenguaje y su compromiso con la realidad (y la realización [fulfillment]). De ese modo, toda la ciencia jurídica de Kelsen será construida sobre suposiciones no examinadas y simplistas acerca de la univocidad de "derecho" y la supuesta necesidad de una única forma de norma que se corresponda una a una con la definición única (single-feature definition) del derecho como un orden social para controlar la conducta a través de la amenaza de la sanción. ${ }^{21} \mathrm{Y}$ la casi universal hostilidad de quienes se autoidentifican como positivistas con el teorema de lex iniusta non est lex pasa por alto la multivocidad de términos tales como "ley" y "validez". Lo que es central en un contexto o para un conjunto de propósitos es secundario en otro contexto o en relación con otros propósitos.

21 Véase Kelsen, Hans, General Theory of Law and State, Harvard University Press, 1945, 19, 45 ("Si la «coerción» en el sentido definido aquí es un elemento esencial del derecho, entonces las normas que conforman un orden jurídico deben ser normas que establecen un acto coercitivo, es decir, una sanción" [non sequitur]). 
Por eso la complejidad de las relaciones entre validez jurídica y legitimidad moral del derecho, y entre obligatoriedad jurídica en un sentido intrasistemático y en un sentido moral, se manifiesta en polos duales de centralidad: el técnico-jurídico y el de lo debido moralmente. Pero dado que los proyectos inmorales o amorales de creación y sostenimiento del derecho son parasitarios de la razonabilidad más plena del derecho moralmente justo, es el segundo polo el que tiene la primacía filosófica, así como primacía en la conciencia del legislador reformista y (con algunas complejidades de responsabilidad añadidas) en la conciencia del auténtico (caso central) juez.

\section{FILOSOFÍA JURÍDICA Y NUEVOS DESAFÍOS ÉTICOS Y POLÍTICOS}

A pesar de que, como se ha dicho ut supra, la filosofía jurídica tiene un espacio y un carácter técnico cuasi-distinto, la idea misma (concepto) del derecho (una idea sin la cual ninguna ley puede ser hecha o sostenida) es tan dependiente de principios más amplios del pensamiento y la filosofía moral y política, que ni el derecho ni su filosofía pueden evitar comprometerse con los problemas éticos y políticos y los desafios de la época. Aspectos particulares del contenido de nuestro derecho (incluyendo sus reglas procedimentales e instituciones) pueden mejorar o, en otros casos, dañar y agravar el bien común de nuestra comunidad. El instrumental jurídico puede, con no poca frecuencia, suministrar una vía fácil para cambios sociales destructivos, tal como el aparato del litigio con derechos humanos (human rights litigation), en muchos lugares, ha provisto de una vía fácil para el aborto, la eutanasia, la inmigración perjudicial y el "matrimonio" del mismo sexo, para la opresión de las críticas de la conducta homosexual y para otros males destructivos. Pero lo que las elites sociales desean puede, con mucha frecuencia, ser alcanzado sin recurrir demasiado a dicho instrumental, o incluso en contradicción con él. 
Me parece que la tarea de la filosofía jurídica es doble hoy en día. Ella debe conservar clara su relación intrínseca con, y su dependencia de, todas las verdades de la filosofía moral y política, en particular por la vía de proveer una crítica constante de cada forma de filosofía jurídica que niegue o distorsione tal relación. Por su dominio y su comprensión explicativa fundacional del instrumental técnico del derecho, debe permanecer en posición de criticar y exponer - en la esperanza de evitar - toda manipulación de ella misma para propósitos destructivos del bien común, un bien que incluye, pero que no se agota por, el sostenimiento de derechos jurídicamente cognoscibles.

De especial importancia en las décadas venideras será una recuperación de la toma de conciencia entre los filósofos del derecho de que la forma paradigmática del derecho, el ius civile, es el derecho de un pueblo ${ }^{22}$ establecido por un acto constituyente (o por una costumbre constituyente) y por continuos actos legislativos de autodeterminación como pueblo, actos que pueden y deberían ser compatibles con sus obligaciones de realizar y respetar derechos (derechos humanos, en cuanto contenidos en el ius naturale) y sus responsabilidades hacia otros pueblos y la autodeterminación, derechos y necesidades de esos otros pueblos. Así como incontables pensadores en los siglos XIX y XX aceptaron demasiado despreocupadamente la justicia de las nociones comunistas de una comunidad sin propiedad, nociones que no atienden adecuadamente a las condiciones de largo plazo para una sustentable, próspera y justa sociedad de personas libres, con el resultado de que incontables millones de personas sufrieron más o menos directamente por la aplicación en sus Estados de esos errores del pensamiento práctico, del mismo modo muchos pensadores de la actualidad aceptan demasiado alegremente (explícita o implícitamente) la justicia de las nociones cuasi-comunistas de una humanidad sin fronteras, nociones incompatibles con las condiciones de largo plazo de un orden político y de un Estado de derecho

22 Véase CEJF, IV.21 sec. V, pp. 430-4, y nota 24 infra. 
sustentablemente justo y civilmente libre. Incluso en el corto plazo, esta clase de error del pensamiento práctico resulta en el tipo de comunidad política crecientemente familiar, cuya interna diversidad multicultural de lealtades supremas de sus pueblos es a la vez promovida y contestada por un aparato de seguridad y vigilancia en permanente crecimiento, una disminución severa de la libertad del discurso político e intelectual, y una explosión de legislación y burocracia regulatoria indiferente al beneficio de lograr una sociedad cuya autodeterminación en gran medida se expresa en aquel compartir expectativas que Ulpiano y Santo Tomás de Aquino ${ }^{23}$ llamaban "costumbre común".

Los que practican la filosofia del derecho pueden ser especialmente susceptibles a este tipo de error, en la medida en que ellos conciban a los sistemas jurídicos simplemente como conjuntos de normas antes que como los principios, normas e instituciones adoptados por un pueblo extendido en límites temporales y territoriales, en cumplimiento más o menos adecuado de su responsabilidad moral de hacerlo así. ${ }^{24}$

23 Véase Summa Theologiae, I-II q. 97 a. 2 (“ddebe siempre modificarse la ley humana cuando existe la oportunidad de hacer una mejora en ella? No").

24 Véase CEJF, IV, en p. 16; CEJF, II ensayos 6 ("Law, Universality and Social Identity") y 7 ("Cosmopolis, Nation States, and Families"), y nota 22, supra. 


\section{SOBRE LA INGOHERENGIA DEL POSITIVISMO JURÍDICO*}

El positivismo jurídico es una empresa intelectual incoherente. Se incapacita a sí mismo para llevar a cabo la tarea explicativa que se propone. En consecuencia, ofrece a quienes lo estudian pretendidas e inválidas derivaciones del deber a partir del ser.

En este breve ensayo apunto varios rasgos del positivismo jurídico y de su historia antes de intentar identificar esta incoherencia esencial. No pretendo renunciar a mi opinión de que la reflexión sobre el derecho y la teoría jurídica se lleva a cabo mejor sin hacer referencia a las inestables y parasitarias categorías académicas o etiquetas tales como "positivismo" (o "liberalismo", o "conservadurismo", etcétera). Uso el término por comodidad, para designar una deslavazada familia de teorías y de pensadores que participan en nuestro diálogo contemporáneo y que han usado el término para describir sus propias teorías, o las teorías jurídicas de los escritores que quieren que admiremos.

La idea de que no hay criterios de conducta salvo aquellos creados - establecidos, puestos - por convenciones, órdenes u otros hechos sociales similares era bien conocida para Platón ${ }^{1}$ y Aristóteles. ${ }^{2}$ El desarrollo de una crítica sostenida de cualquier idea

* Publicado originalmente como "Propter honoris respectum. On the Incoherence of Legal Positivism", Notre Dame Law Review, 2000, 75, pp. 1597-1611. Traducción de C. Pereira Sáez. Supervisión de Carlos I. Massini-Correas.

1 Véase Platón, Las leyes, IV.

2 Véase Aristóteles, Ética a Nicómaco, I, § 13. 
de este tipo fue un objetivo primordial de estos filósofos y, en alguna medida, de sucesores suyos, como Cicerón. ${ }^{3}$ Actualmente, los impulsores de esta clase radical de "positivismo excluyente" son los seguidores, conscientes o inconscientes, de Nietzsche o de otros que, como él, reducen la ética y la teoría normativa política o jurídica a una búsqueda de la "genealogía" de las fuentes históricas (quizá en parte o completamente psicológicas) de los criterios éticos, políticos o jurídicos. Estos autores suponen o declaran que estas fuentes sólo pueden consistir en un ejercicio de voluntad de individuos carismáticos o de grupos que ambicionan el poder, o en los impulsos y compulsiones subracionales de dominación, sumisión, etcétera, supuestamente similares a la voluntad.

El positivismo jurídico es, en principio, una propuesta más modesta: la de que el derecho estatal es, o debería ser, sistemáticamente estudiado como si fuera un conjunto de normas originadas exclusivamente por convenciones, órdenes y otros hechos sociales similares. Tal y como fue desarrollado por Bentham, Austin y Kelsen, el positivismo jurídico era oficialmente neutral respecto de la cuestión de si, fuera del derecho, hay criterios morales cuyo carácter directivo (normatividad, autoridad, obligatoriedad) en la deliberación no es completamente explicado por ningún hecho social. Por supuesto que Bentham y Austin no creían que la obligatoriedad de la moral utilitarista que promovían dependiese de la aprobación de alguna persona o algún grupo, aun cuando Austin sostuviera que todo el contenido de las normas utilitaristas está también ordenado por Dios. La teoría oficial de Kelsen, hasta casi el final de su vida, era - por lo menos cuando estaba haciendo filosofía jurídica - que puede haber verdades morales, pero si las hay, están totalmente fuera del campo visual de la ciencia jurídica o filosofía jurídica. Sin embargo, al final de su vida su postura fue de un completo escepticismo moral ${ }^{4}$ o de un vo-

3 Véase Cicerón, De Finibus, 1-7, 3.20.

4 Véase, e. g., Kelsen, H., General Theory of Norms, trad. de M. Hartney, Oxford University Press, 1990, pp. 226. 
luntarismo moral puro: las normas morales no podrían ser otra cosa que mandatos divinos, si Dios existiese. Estas tesis últimas de Kelsen son la consumación no sólo de la línea voluntarista que recorre todo su pensamiento sobre el derecho positivo, sino también de todas las teorías anteriores que daban por supuesto que el derecho y su obligatoriedad son y deben ser producto de la voluntad y el poder coactivo de un superior.

La generalmente llamada Escuela Moderna del Derecho Natural ejemplifica, en gran parte, esta teoría. Esta tradición surge claramente antes de 1660, año en que Samuel Pufendorf publicó en La Haya su Elementorum jurisprudentiae universalis libri duo. ${ }^{5}$ Aquí, o en el largamente inédito Questions Concerning the Law of Nature ${ }^{6}$ (hacia 1660-1664) de John Locke, pueden estudiarse rasgos característicos de este tipo de teoría del derecho natural. Ambos escritores son claramente deudores de Hugo Grocio en algunas cosas, y de Thomas Hobbes en otras. De manera muy significativa, Pufendorf describe De cive (1642), de Hobbes, donde se anuncian las principales tesis morales y jurídicas de su más famoso Leviathan (1651), como "en su mayor parte sumamente aguda y sólida"?

A partir del influyente De iure belli at pacis (1625) de Grocio, Locke y Pufendorf toman la idea, atractiva pero bastante opaca, de que la moral y los principios básicos del derecho son una cuestión de "conformidad con la naturaleza racional". ${ }^{8}$ Estos autores nunca abordan en serio las preguntas relativas a cómo se conoce esa naturaleza y por qué es prescriptiva para toda persona. Hobbes afronta y contesta tales preguntas fundamentales. Sin embargo, sus respuestas tratan nuestro razonamiento práctico como si

5 Pufendorf, S., Elementorum jurisprudentiae universali libri duo (trad. De W. Abbott Oldfather, Clarendon Press, 1931) 1672.

6 Locke, J., Questions Concerning the Law of Nature (trad. de R. Horwitz et al., Cornell University Press, 1990), 1664.

7 Pufendorf, S., op. cit., xxx.

8 Grocio, H., De Fure Belli at Pacis (trad. de F.W. Kelsey, William S. Hein \& Co., 1995), 1625, libro I, p. 38. 
estuviese por completo al servicio de la motivación de pasiones sub-racionales, como el miedo a la muerte o el deseo de superar a los demás - motivos del mismo tipo que la tradición clásica considera que necesitan ser dirigidos por la captación por la razón de los fines últimos y mejores, de bienes verdaderos e intrínsecos, de razones realmente inteligentes para la acción-.

"[N]inguna ley sin legislador". ${ }^{9}$ Ninguna obligación sin sujeción a la "voluntad de un poder superior". ${ }^{10}$ "La definición formal de la ley es: la declaración de una voluntad superior". ${ }^{11}$ "La norma de nuestras acciones es la voluntad de un poder superior". ${ }^{12}$ La ley sin (la perspectiva de) el castigo es vana. ${ }^{13}$ Los fundadores de la Escuela Moderna de la Ley Natural consideran estas definiciones y axiomas (que son de Locke) aplicables tanto a la ley natural, los principios mismos de la moral, como al derecho positivo de los Estados. ${ }^{14}$ Así, la obligación se está "deduciendo" abiertamente de un hecho, el hecho de que tal o cual cosa ha sido querida por quien tiene poder para infligir un daño. Es cierto que cuando está en juego la ley natural (la moral), se supone que el superior, Dios, es sabio. Pero a la idea de la divina sabiduría no se le da ningún papel positivo en la explicación de por qué los mandatos divinos crean obligaciones para una conciencia racio-

9 Locke, J., op cit., p. 193.

10 Ibidem, p. 167; véase, también, p. 159.

11 Ibidem, p. 103.

12 Ibidem, p. 205.

13 Véase ibidem, p. 193.

14 Véase, e. g., Pufendorf, S., op. cit., p. 89: "Porque, si has excluido a Dios de la función de administrar justicia, toda la eficacia de... los pactos, a cuya observancia una de las partes contratantes no puede obligar por la fuerza a la otra, se extinguirá de inmediato, y cada uno medirá la justicia según su propia ventaja particular. Y, ciertamente, si queremos confesar la verdad, una vez que se ha suprimido el temor a la venganza divina, no parece haber razón suficiente por la que yo debiera estar en absoluto obligado, una vez que las condiciones que determinan mi ventaja hayan cambiado, para proporcionar aquello que me había obligado a proporcionar a la otra parte cuando mis intereses me orientaban en aquella dirección; siempre que, por supuesto, no tenga mal real alguno que temer, por lo menos de ningún hombre, como consecuencia de ese acto”. 
nal. El derecho de Dios a legislar se explica, en cambio, mediante la analogía del puro poder: “¿Quién, en efecto, dirá que el barro no está sujeto a la voluntad del alfarero, y que la vasija no puede ser destruida por la misma mano que la formó?". ${ }^{15}$

Locke, como Hobbes, es incómodo, aunque vagamente consciente de que el "deber" no puede inferirse del "ser" sin algún "deber" ulterior. Es decir, es incómodamente consciente de que el hecho de que una conducta fue querida por un superior, o incluso por una parte de un contrato, no explica por qué esa conducta es obligatoria ahora. Por eso piensa, a veces, en completar su crudo voluntarismo (los deberes se explican por actos de voluntad) con la racionalidad de la coherencia lógica: los principios morales fundamentales son tautologías, normas que sería autocontradictorio negar. ${ }^{16}$ Hobbes había aventurado una explicación similar de la obligatoriedad de los contratos (como su contrato social fundamental de sujeción al soberano). Aun así, su explicación oficial y más importante era del tipo "triunfan bastos" (la voluntad respaldada por una fuerza superior, esto es, por la capacidad de infligir un daño). ${ }^{17}$ Este recurso a la coacción admite tácitamente que el hecho de que alguna otra persona haya querido que haga o me haya ordenado hacer algo no proporciona por sí mismo razones para la acción, ni normatividad o carácter directivo para mis deliberaciones.

Más aún, como argumenta Kelsen, la confianza en la voluntad de un superior para explicar el derecho y su normatividad no deja, al final, lugar a exigencia alguna de consistencia lógica en el derecho, ni a ningún intento de razonar desde una regla general (el asesinato ha de ser castigado) hasta una conclusión obligatoria

15 Locke, J., op. cit., p. 167; véase, también, pp. 164-166: “[P] atet... posse homines a rebus sensibilibus colligere superiorem esse aliquem potentem sapientemque qui in homines ipsos jus habet et imperium. Quis enim negabit lutum figuli voluntati esse subjectum, testamque eadem manu qua formata est" (cursivas añadidas).

16 Véase ibidem, pp. 178 y 179 (este pasaje fue suprimido por Locke en 1664).

17 Véase Finnis, J., Natural Law and Natural Rights, Oxford, Clarendon Press, 1980 , pp. 348 y 349. 
(Smith, habiendo asesinado a Jones, ha de ser castigado). ${ }^{18}$ De ahí la postura final de Kelsen, penosa para muchos que quieren ser positivistas: la única fuente de normatividad y, por tanto, de la normatividad de una norma particular, es la positividad, es decir, la volición real de esa norma por un superior. Desde este presupuesto, ni siquiera la racionalidad del razonamiento jurídico lógico e incontrovertido puede nunca dar lugar a la obligatoriedad: nada, excepto un acto de la voluntad, puede hacerlo. ${ }^{19}$

Las tesis últimas de Kelsen no pueden ser anuladas como excentricidades de interés meramente biográfico. De todas formas, el positivismo jurídico — llamado a veces "positivismo jurídico excluyente"- defendido hoy por filósofos del derecho como Joseph Raz es muy diferente. A la vez que afirma que todo el derecho se basa en y es validado por fuentes fáctico-sociales - afirmación que le hace positivismo jurídico excluyente--, acepta también que los jueces puedan tener, y no es raro que tengan, la obligación jurídica y moral de incluir en su razonamiento judicial principios y normas que son aplicables porque, aunque no son jurídicamente válidas (porque hasta el momento no han sido puestas por ninguna fuente fáctico-social), son o el juez en cuestión las considera moralmente verdaderas. ${ }^{20}$

La teoría clásica de la ley natural no rechaza las tesis de que lo que ha sido puesto es positivo y lo que no ha sido puesto es no positivo (de hecho, el mismo término "derecho positivo" es un término importado a la filosofía por Tomás de Aquino, que fue también el primero en proponer que todo el derecho de una comunidad polí-

18 Véase Kelsen, H., op. cit., pp. 189-193 y 211-251.

19 Véase ibidem, p. 6: "En términos generales: ningún Deber sin una voluntad (aunque sea sólo ficticia)".

20 Véase, e. g., Raz, J., Ethics in the Public Domain, Oxford, Clarendon Press, 1994 , pp. 190 y 191. 
tica puede ser filosóficamente considerado como derecho positivo). ${ }^{21}$ Sin embargo, estas tesis necesitan en gran medida ser aclaradas. ¿Qué significa decir que una regla, principio u otra norma "ha sido puesta por una fuente fáctico-social”? ¿Significa lo que entendió que significaba el último Kelsen, que nada menos que el expreso establecimiento de la norma misma en toda su especificidad - y ningún tipo de mera derivación (inferencia) o posibilidad de derivación - es suficiente? Es virtualmente imposible encontrar algún otro positivista que siga a Kelsen en esto. Pero, si no es así, ¿qué tipo de consistencia-con-lo-que-ha-sido-específicamente-establecido por una fuente fáctico-social es necesaria y suficiente para que una norma merezca ser considerada como "puesta”? ¿Según qué criterios ha de contestarse esta última pregunta teórica?

Está claro, entonces, que los filósofos del derecho tienen escasos motivos para contentarse con idea alguna de que la teoría jurídica debe, simplemente, informar de los hechos sociales relativos a qué ha sido y qué no ha sido expresamente puesto mediante actos reales de expresión deliberada, en esta o aquella comunidad. El mismo Raz va bastante más allá de un proyecto así de limitado cuando afirma que los tribunales tienen, característicamente, el deber jurídico y/o moral de aplicar normas no jurídicas.

Considérese ahora el proceso judicial o jurídico de identificación de una norma moral como norma que cualquiera que decida un caso determinado tiene el deber de aplicar, aun cuando no haya sido (todavía) puesta por el hecho social de la costumbre, la promulgación o la previa decisión judicial. Esta norma moral determinada será, normalmente, una especificación de un principio moral muy general, como la equidad, que rechaza el trato favorable o desfavorable que resulta arbitrario cuando se evalúa según los principios de que los casos iguales deben tratarse de la misma manera y los casos distintos de manera diferente, y de que uno debe hacer por los demás lo que le gustaría que los

21 Véase Finnis, J., "The Truth in Legal Positivism", en George, R. (ed.), The Autonomy of Law, Oxford, Clarendon Press, 1996, pp. 195-214. 
demás hiciesen por él o por las personas a quienes ya favorece. Pero tal especificación - hacer más específico- de un principio moral general no puede tener lugar sin atender cuidadosamente al modo en que ya la ley indiscutidamente puesta trata a las personas, cosas y actividades. Sin esa atención, no puede establecerse qué casos son iguales y qué casos diferentes, ni saber a qué clases de personas, actos o cosas la ley positiva existente favorece o desfavorece. Por lo tanto, sólo quienes conocen el conjunto de leyes relevantes lo bastante bien como para saber qué nueva norma de solución de conflictos realmente se adecúa mejor que otra norma alternativa pueden hacer adecuadamente la elección de la norma moralmente correcta, de la solución moralmente correcta para el caso que se tiene entre manos. Esta elección, cuando es hecha de esta manera por los jueces, es, en cierto modo, crear derecho nuevo. Sin embargo, esta responsabilidad judicial, como los jueces se recuerdan periódicamente a sí mismos (y a los abogados, y a su público), difiere significativamente de la autoridad de los legisladores para promulgar medidas revocatorias generales, para hacer clasificaciones novedosas de las personas, cosas y actos, y trazar líneas claras de distinción que podrían, de forma razonable, haber sido trazadas de otra manera. Puede, razonablemente, señalarse esta significativa diferencia diciendo que la "nueva" norma judicialmente adoptada, al estar tan estrechamente controlada por las contingencias del derecho puesto existente, era $y a$, en un sentido importante, parte del derecho. ${ }^{22} \mathrm{El}$ rechazo del positivismo jurídico excluyente de aceptar este modo de hablar es infundado y está inadecuadamente motivado.

\section{III}

Para un juez, y para un abogado que intenta seguir el razonamiento judicial, el derecho tiene una doble vida.

22 Véase Finnis, J., “The Fairy Tale's Moral”, Law Quartely Reviewe, 115, 1999, pp. 170, 174 y 175. 
Una de sus vidas (por decirlo de alguna manera) es (i) su existencia como el puro hecho de que determinadas personas han hecho esto y lo otro en el pasado, y de que determinadas personas tienen, aquí y ahora, tal y tal otra disposición para decidir y actuar. Estos hechos proporcionan su explicación del derecho de una comunidad al "positivismo jurídico excluyente" (nótese, sin embargo, que los positivistas jurídicos empiezan a abandonar, con razón, la opinión de que la teoría jurídica debe atender sólo a aquello que está puesto en las fuentes fáctico-sociales, al afirmar que el derecho es sistemático: el contenido de lo que se considera "expresamente puesto" es establecido por el contenido de otras reglas y principios del sistema, con el resultado de que incluso si estas otras normas están, cada una de ellas, puestas por hechos sociales, ningún creador del derecho, judicial o de otro tipo, establece, de hecho, o puede establecer por sí mismo el contenido y efecto jurídicos de su acto - el hecho social - de posición).

La otra vida del derecho es (ii) su existencia como criterio directivo para las deliberaciones en conciencia de quienes tienen la responsabilidad de decidir (hacer justicia) según el derecho. Desde este punto de vista "interno", los hechos sociales de posición aportan muy poco y demasiado. Muy poco porque en los casos de desarrollo jurídico del tipo que he esbozado, estos hechos, aunque no son irrelevantes, deben completarse con las normas morales a aplicar por verdaderas. Y demasiado porque, a veces, las fuentes fáctico-sociales producen normas tan viciadas desde el punto de vista moral que incluso los jueces que han jurado seguir el derecho deben rechazarlas en favor de reglas alternativas más coherentes con los principios morales (con la plena conformidad con la razón práctica) y con todas aquellas otras partes del derecho puesto que son coherentes con el principio moral.

Los "positivistas jurídicos incluyentes" son reacios a separar la pregunta “¿cuál es el derecho que rige este caso?” de la pregunta “¿cuál es, según nuestro derecho, mi deber como juez en este caso?". Si el derecho de la comunidad considerado en su 
conjunto, explícita o implícitamente, exige, o incluso autoriza, a los jueces a que se pregunten, en cierto tipo de casos, qué exige la moral en circunstancias de ese tipo, entonces la norma o normas morales que respondan a esa pregunta - o por lo menos las conclusiones morales aplicables en tales circunstancias - tienen autoridad tanto jurídica como moral. La norma o normas morales, en esta medida y por esta razón, han de ser consideradas como parte de nuestro derecho. Están, como dicen algunos, "incluidas" en, o "incorporadas" al derecho de la comunidad. El positivista jurídico excluyente (recordamos) insiste en que tales normas, incluso aunque determinen el deber de los jueces en un caso tal, quedan fuera del derecho, excluidas por su carencia (al menos hasta el momento) de pedigrí fáctico-social.

Las discusiones entre positivistas jurídicos excluyentes e incluyentes son, en mi opinión, un estéril conflicto de demarcaciones, poco más que una disputa acerca de las palabras "derecho" y "sistema jurídico". Es posible, sin duda, considerar el derecho en general, y el derecho de una comunidad particular, pasada o presente, como (i) un hecho complejo relativo a las opiniones y prácticas de un conjunto de personas en un momento dado. Quienes consideran el derecho precisamente de este modo tienden, de manera no irrazonable, a dar prioridad a las creencias y a las prácticas de aquellos miembros de la comunidad que se ocupan del derecho como profesionales, tales como jueces, asesores jurídicos, agentes judiciales, policía, etcétera. Al describir este complejo hecho, bien pueden (como hace Hart) tratar al derecho como una razón para la acción, y describir la ley como un conjunto de razones (de las que algunas autorizan, algunas obligan y algunas hacen ambas cosas) que se sistematizan mediante interrelaciones de derivación, restricción interpretativa y otros tipos de interdependencia, y que pretenden dar una orientación coherente. Aun así, dado que este tipo de teóricos se interesan por los hechos relativos a las creencias y prácticas de un grupo de personas, no necesitan hacer juicios sobre si las normas del sistema son, de hecho, coherentes, o si sus reglas más básicas de vali- 
dación, autorización, creación y reconocimiento explican de manera satisfactoria las otras normas del sistema, o dan a cualquiera una razón verdaderamente razonable y racionalmente suficiente para actuar de una manera específica, sea como juez, ciudadano o de algún otro modo.

Es posible, sin embargo, considerar el derecho, y el derecho de una comunidad particular, precisamente como (ii) buenas razones para la acción. Pero cuando la deliberación sigue su curso, las razones que tenemos para la acción (y para abstenernos de la acción) realmente buenas y las únicas que son de verdad suficientes son razones morales: esto es lo que significa que una razón sea moral a los ojos de cualquiera que procura pensar y actuar con la autonomía, auto-determinación y rectitud de conciencia que la tradición clásica hace centrales. ${ }^{23} \mathrm{Y}$ es obvio que, para los propósitos de este tipo de consideración, nada contará como derecho a no ser que esté de acuerdo con las exigencias de la moral, tanto positivas como negativas. Una moral sólida exige, ciertamente, que nos preocupemos de hacer, aplicar, cumplir y sostener las leyes positivas, basadas en fuentes fáctico-sociales y con pedigrí, y que las mantengamos en coherencia entre sí. Estas leyes positivas añaden algo, mucho en realidad, a las directrices inherentes a la moral. Este algo añadido es específico para la comunidad, el momento y el lugar en cuestión, incluso si es, como sin duda muchas veces debe ser, igual en contenido a las normas de derecho positivo sobre las materias relevantes de otras comunidades particulares.

La teoría clásica de la ley natural se ocupa, principalmente, del segundo tipo de investigación. Pero tiene un absoluto respeto hacia las consideraciones descriptivas, históricas, "sociológicas" del primer tipo, y trata de beneficiarse de ellas. La teoría clásica de la ley natural también ofrece razones ${ }^{24}$ para juzgar que

23 Véase Platón, Gorgias; Aquino, Tomás de, Summa Theologiae, I-II, prólogo, y Finnis, J., Aquinas. Moral, Political, and Legal Theory, Oxford, Oxford University Press, 1998, pp. 20, 124 y 125.

24 Véase Finnis, J., Natural Law..., cit., pp. 3-22. 
las descripciones generales del derecho serán fructíferas sólo si su estructura conceptual básica se deriva, de manera consciente y crítica, de la comprensión de las buenas razones que las investigaciones del segundo tipo tratan de alcanzar mediante el debate abierto y la valoración crítica.

Cualquiera que haga y se adhiera firmemente a esta distinción básica entre (i) las preguntas acerca de lo que es (o era, o es probable) y (ii) las preguntas acerca de lo que debe ser, observará que gran parte del debate entre los positivistas jurídicos surge de, o por lo menos supone, una falta de atención a esta distinción. De hecho, mucha de la literatura iusfilosófica contemporánea parece balancearse sin remedio entre lo rigurosamente descriptivo ("externo" a la conciencia) y lo rigurosamente prescriptivo ("interno" a la conciencia), ofreciendo varias, pero siempre incoherentes, mezclas de los dos. ¿Qué es lo que permite a los positivistas jurídicos "excluyentes" sostener, ni siquiera conceder, que los jueces tienen, a veces, el deber de salir del derecho y aplicar normas morales? ¿Cómo puede un "positivismo" consagrado a (según dicen) los hechos incluir propuestas sobre el deber moral?

Una comprensión rigurosamente descriptiva del derecho de Ruritania no puede hacer más que informar de la más o menos amplia aceptación que existe en Ruritania de que, en determinadas circunstancias, los jueces deban resolver los casos mediante la aplicación de normas que juzgan moralmente verdaderas, aunque no tengan pedigrí - es decir, aunque no estén, hasta el momento, certificadas por alguna fuente fáctico-social del derecho- Supóngase ahora que la regla de reconocimiento referida incluye en sus propios términos la declaración de que cualquier norma sin pedigrí que los jueces estén obligados o autorizados por dicha regla de reconocimiento a aplicar (porque la consideren moralmente verdadera) debe ser entendida y declarada por los jueces parte integral del derecho de la comunidad. ¿Qué razón tienen los positivistas excluyentes para decir que tal regla de reconocimiento es, de alguna manera, infiel a la naturaleza del derecho? 
Supóngase, por otro lado, que la regla de reconocimiento de Ruritania estipula que cuando a los jueces se les exija o se les autorice a aplicar una norma sin pedigrí porque la consideren moralmente verdadera, éstos deben hacerlo tratándola no como parte del derecho de Ruritania, sino más bien como análoga a aquellas reglas de Estados extranjeros que son aplicables en los tribunales de Ruritania en virtud de las reglas de elección-delderecho del derecho de conflictos de leyes de Ruritania (esta estipulación bien podría tener consecuencias jurídicas, como en los casos relativos a la aplicabilidad retroactiva de la norma, o a su uso en la valoración de si ha habido un "error de derecho" para los propósitos de las reglas de limitación de la acción o de restitución). ¿Qué razón tienen los "positivistas jurídicos incluyentes" para sostener que esta regla de reconocimiento es, de alguna manera, infiel a la naturaleza del derecho? Pero si reconocen que no es en modo alguno infiel a la naturaleza del derecho, ¿qué es "positivista" en su postura? Y ¿es posible que una polémica ilusfilosófica entre "ismos" rivales tenga un contenido teórico serio si puede verse afectada por lo que una comunidad determinada declare que es su derecho?

En mi opinión, en la polémica contemporánea entre positivistas jurídicos excluyentes e incluyentes no está en juego de forma sistemática ninguna verdad sobre el derecho. No vale la pena continuar con la discusión principal. Siempre que se sea claro e inequívoco con los lectores, no importa nada que el derecho positivo se defina como (todas y sólo) las normas con pedigrí o, en cambio, como (todas y sólo) las normas aplicables por los jueces cuando actúan como tales. ${ }^{25}$ Cada una de las definiciones tiene sus ventajas y sus inconvenientes. Considerar derecho sólo lo que tiene pedigrí tiene los inconvenientes ya mencionados: (a) la re-

25 Véase un ejemplo de la polémica sobre cuál de estas alternativas es correcta en Dworkin, R., "A Reply by Ronald Dworkin", en Cohen, M. (ed.), Ronald Dworkin and Contemporary Furisprudence, London, Duckworth, 1984, p. 261, y Raz, J., "Legal Principles and the Limits of the Law", en Cohen, M., op. cit., pp. 84 y 85. 
lación entre el deber jurídico y el deber de los tribunales parece caer fuera de la "ciencia" o "filosofia" del derecho, y (b) parece que no hay ninguna manera de especificar con precisión qué se considera "con pedigrí" ("derivado", "derivable", etcétera), excepto la amputación de la mayor parte del método y del pensamiento jurídico - de todo razonamiento de una norma a otra, o a partir de la coherencia sistemática- que hace el último Kelsen en virtud de su exigencia de que haya un acto específico de voluntad que dé pedigrí a todas y cada una de las proposiciones de derecho. Considerar derecho cualesquiera normas que los tribunales tengan el deber judicial de imponer tiene el inconveniente de que no puede hacerse bien - de manera crítica y suficiente - sin asumir precisamente la tarea de la doctrina clásica de la ley natural, y seguir, en lo sustancial, su camino.

\section{IV}

Como he apuntado, la "positividad" del derecho fue expresada, adoptada y explicada por primera vez por los filósofos clásicos de la ley natural. El positivismo jurídico se identifica a sí mismo como un desafío para las teorías del derecho natural. Ha tenido, digamos, 225 años ${ }^{26}$ para hacer inteligible este desafio. La mejor exposición que sus defensores contemporáneos pueden ofrecer de este desafío es "no hay una relación necesaria entre el derecho y la moral". ${ }^{27}$ Pero la filosofía del derecho clásica ha afirmado siempre

26 Esto es, desde Jeremy Bentham. Véase Bentham, J., A Comment on the Commentaries and a Fragment on Government (ed. de J. H. Burns y H. L. A. Hart, Humanities Press, 1977), 1776.

27 Coleman, J. L. y Leiter, B., "Legal Positivism", en Patterson, D. (ed.), A Companion to Philosophy of Law and Legal Theory, Oxford, Blackwell, 1996, pp. 241260. Los autores añaden otra "creencia central" y otro compromiso "ulterior": (i) "qué se considere derecho en una sociedad particular es fundamentalmente una cuestión de hecho social o convención («la tesis social»)" (ibidem). El filósofo iusnaturalista clásico observará que esto es equívoco entre a) la proposición tautológica de que lo que es considerado derecho en una sociedad particular 
este enunciado con entusiasmo. Algunas leyes son completamente injustas, completamente inmorales; el hecho de que las fuentes sociales autorizadas o reconocidas como fuentes de derecho válido declaren o promulguen algo como derecho no implica en modo alguno que sea (ni siquiera que alguien lo considere) moralmente aceptable, ni siquiera que sea relevante a la hora de considerar las responsabilidades morales de alguien (sean verdaderas o correspondan a una concepción convencional o idiosincrásica). Por lo tanto, no hay ninguna relación necesaria entre el derecho y la moral o la responsabilidad moral. La pretensión de que las teorías del derecho natural pasan por alto algunos de los hechos sociales relevantes para el derecho es simplemente, y de manera demostrable, falsa.

De este modo, el enunciado que presuntamente define el positivismo jurídico necesita en gran medida ser aclarado. ${ }^{28} \mathrm{Y}$, lo que es aún más fundamental, no es posible hacer ninguna aclaración seria sin considerar ambos términos de la supuesta disyuntiva: derecho $y$ moral. No es posible afirmar racionalmente que no hay relación necesaria, en ningún sentido relevante de "relación" ni de "necesidad", sin atender de manera crítica y seria a lo que la moral tiene que decir respecto del derecho, ya sea en general, ya sea como el derecho de comunidades determinadas. ¿Qué fundamento hay para sostener, dar a entender o permitir que se crea que los abogados, los jueces y otros ciudadanos o sujetos del de-

es considerado derecho en esa sociedad, y b) la proposición falsa de que lo que las personas completamente razonables (por ejemplo, los jueces completamente razonables) que reflexionan sobre sus responsabilidades consideran derecho es todo y sólo aquello que otras personas de esa sociedad consideran derecho -falso porque ser no implica deber (por ejemplo, el deber de la responsabilidad razonable)-; (ii) "un compromiso con la idea de que los fenómenos que comprenden el ámbito en cuestión (por ejemplo, el derecho...) deben ser accesibles a la inteligencia humana"; la teoría clásica del derecho natural participa plenamente en este compromiso en cuanto define la ley natural como los principios accesibles a la inteligencia humana, y la ley positiva como las reglas diseñadas por las inteligencias humanas.

28 Véase Finnis, J., “The Truth...”, cit., pp. 203 y 204. 
recho no deben o no necesitan atender - precisamente cuando consideran cómo afecta el derecho a sus responsabilidades como abogados, etcétera - a la pregunta de qué tiene la moral que decir sobre el derecho y sobre qué merece ser considerado derecho? Y ¿dónde va a encontrar el estudioso del derecho tal atención crítica y seria a la moral en cuanto afecta al derecho, y a la misma idea de derecho, y a los derechos particulares, que no sea en la investigación que, cualquiera sea su etiqueta, se extiende tanto y tan ambiciosamente como la filosofía clásica de la ley natural?

Considérese el siguiente argumento recientemente ofrecido por Jules Coleman y Brian Leiter:

Ahora puede verse el problema de la explicación de la autoridad del jurista iusnaturalista. Porque, una norma, para ser derecho, debe ser exigida por la moral. La moral tiene autoridad, en el sentido de que el hecho de que una norma sea una exigencia de la moral da al agente una razón (quizá superadora) para cumplirla. Si la moral tiene autoridad, y las normas jurídicas son necesariamente morales, entonces el derecho tiene, también, autoridad.

Sin embargo, este argumento de la autoridad del derecho es, en realidad, fatal para él, porque hace a la autoridad del derecho una repetición de la de la moral... si todas las exigencias jurídicas son también exigencias morales (como creería el jurista iusnaturalista) entonces el hecho de que una norma sea una norma de derecho no proporciona a los ciudadanos una razón adicional para la acción. La teoría del derecho natural es, entonces, insuficiente para explicar la autoridad del derecho. ${ }^{29}$

La crítica que emiten aquí Coleman y Leiter fracasa por completo. Ninguna teoría del derecho iusnaturalista ha pretendido nunca que "una norma, para ser derecho, debe ser exigida por la moral", ni que "todas las exigencias jurídicas son también" - con independencia de haber sido válidamente puestas como derecho- "exigencias morales". Los filósofos iusnaturalistas sos-

29 Coleman, J. y Leiter, B., op. cit., p. 244. 
tienen que el contenido de una regla jurídica justa y válidamente promulgada, como "está prohibido ir a más de 35 m.p.h por ciudad", NO es exigido por la moral mientras no sea válidamente establecido por la autoridad jurídica con competencia (con autoridad jurídica) para hacer una regla tal. El elemento central de la filosofía del derecho iusnaturalista es su explicación de cómo la elaboración del derecho "estrictamente positivo" puede crear obligaciones morales que NO existían hasta el momento de la promulgación.

Lamentablemente, el error de Coleman y Leiter, profundo como es, tiene muchos precedentes. Kelsen, en concreto, solía alegar que, según la filosofía del derecho natural, el derecho positivo es una mera "copia" del derecho natural, y "simplemente reproduce el verdadero derecho, de alguna manera ya existente", 30 afirmación que, según se ha demostrado, es una mera caricatura. ${ }^{31}$ Como Coleman y Leiter, Kelsen no citó ningún texto que apoyase su alegación sobre lo que la filosofía del derecho natural dice, porque (como tuvo todas las oportunidades de saber) ninguno podía ser citado.

Como los cincuenta y cinco años de la teoría del derecho de Kelsen ponen perfectamente de manifiesto, los esfuerzos del positivismo por explicar la autoridad del derecho están condenados al fracaso. Porque, como bien dicen Coleman y Leiter, "una autoridad práctica es una persona o una institución cuyas directrices dan a los individuos una razón para actuar (en cumplimiento de estos dictados)"32 y, podrían haber añadido, una razón que no es una mera réplica, para cada individuo, de las razones "prudenciales" de su propio interés para actuar de esa manera. Sin embargo, como deberían reconocer (pero no lo hacen), ningún

30 Kelsen, H., General Theory of Law and State, trad. de A. Wedberg, Harvard University Press, 1945.

31 Véase Finnis, J., Natural Law..., cit., p. 28.

32 Coleman, J. y Leiter, B., op. cit., p. 243 (cursivas añadidas). Por "dictados" entiéndase directriz o prescripción (ley, sentencia judicial, etcétera). Véase Finnis, J., Aquinas..., cit., p. 256, nota 4. 
hecho o conjunto de hechos, por muy complejo que sea, puede proporcionar por sí mismo una razón para actuar, menos aún un "deber" del tipo de los que podrían tener autoridad sobre el interés propio de un individuo (como se dijo, la "autoridad" que no hace más que seguir el rastro del "quiero" del interés propio es redundante para el individuo a quien se dirige e inútil para la comunidad). Ningún deber a partir de un mero ser. Así, el positivismo, en la medida en que se enorgullece de ocuparse sólo de hechos, no puede ofrecer una comprensión adecuada ni de las razones para la acción (los deberes) ni de la única fuente concebible de estos deberes, es decir, los verdaderos e intrínsecos valores (los bienes humanos básicos y los primeros principios del razonamiento práctico, proposicionales, que nos dirigen hacia esos bienes como algo-que-ha-de-procurarse, y señalan a lo que les perjudica como algo que ha-de-evitarse).

\section{V}

La incoherencia del positivismo jurídico - su incapacidad, inherente y auto-impuesta para llevar a cabo la tarea explicativa que se propone - resulta muy bien ilustrada por el esfuerzo de Coleman y Leiter por explicar "la autoridad de la regla de reconocimiento". ${ }^{3}$ Dado que introducen su explicación con la observación de que "todos reconocemos casos de leyes vinculantes que son moralmente censurables (por ejemplo, las leyes que respaldaban el apartheid en Sudáfrica)", ${ }^{34}$ podemos examinar convenientemente sus explicaciones de esta obligatoriedad, de esta condición autoritativa, preguntando cómo podrían figurar tales explicaciones en las deliberaciones de un funcionario (digamos, Nelson Mandela en la década de los cincuenta) en Sudáfrica en aquellos días. El joven Mandela (imaginemos) pregunta a Coleman y Leiter por qué la regla de reconocimiento sudafricana, que sabe que es el contenido

\footnotetext{
33 Coleman, J. y Leiter, B., op. cit., p. 248.

34 Ibidem, p. 243.
} 
proposicional de las actitudes que acompañan y respaldan el hecho sustancial de la concurrencia del comportamiento oficial en Sudáfrica, le da una razón para la acción de un tipo tal que pueda, razonablemente, juzgar como autoritativa. ¿Cómo, pregunta, puede este hecho de la concurrencia del comportamiento oficial hacer que el derecho sea no simplemente aceptado como jurídicamente autoritativo, sino realmente autoritativo como derecho para él y para cualquier otra persona que reconozca su injusticia?

La explicación de Coleman y Leiter es la siguiente: (1) a menudo, tu propio interés te exige coordinar tu comportamiento con el de estos funcionarios y otras personas que, de hecho, están actuando al igual que ellos (pero Mandela está preguntando por directrices autoritativas, no por las orientaciones del interés propio. El interés propio exige la cooperación con los gángsters locales, pero sus indicaciones no son autoritativas); (2) además, en caso de que creas que aquellos funcionarios están intentando hacer lo que exige la moral, tienes una razón para seguir su ejemplo (Mandela no lo creerá, y con razón); (3) puedes "creer que la regla de reconocimiento proporciona algo así como los criterios correctos para estimar la validez de las normas subordinadas a esta regla"35 (Mandela, con razón, no lo cree); (4) "[A]1 margen de [tus] opiniones relativas a los méritos sustantivos de la regla de reconocimiento en sí misma, la evitación de la confusión y el caos, así como las condiciones de la estabilidad liberal[,] exigen la coordinación entre los funcionarios". ${ }^{36}$

Aquí, por fin, en el punto (4), Coleman y Leiter ofrecen una razón del tipo relevante, una razón sobre la que podría debatirse racionalmente, confrontándola con razones del mismo tipo. La exigencia que se afirma en la frase citada va mucho más allá del "hecho de la concurrencia del comportamiento"; reconoce importantes valoraciones relativas al orden, la paz y la justicia (al "liberalismo"); en realidad, no es sino una exigencia moral. Es po-

35 Ibidem, p. 248.

36 Idem. 
sible explicar la condición autoritativa del derecho sólo si se reconoce que la "tesis de la posibilidad de separación" confunde tesis defendibles e indefendibles, y si se abandona, como el error que es, la interpretación o versión "positivista" que Coleman y Leiter apoyan. En la filosofía del derecho hay un nombre para la teoría del derecho que se compromete a identificar y debatir, abierta y críticamente, los principios y exigencias morales que responden a las peticiones de las personas que deliberan de que se les muestre por qué una norma jurídica, válidamente promulgada, es obligatoria y autoritativa para ellos precisamente como derecho: este nombre es (para bien y para mal) el de "teoría del derecho natural".

Coleman y Leiter podrían replicar que estoy confundiendo la autoridad jurídica con la moral. Pero este tipo de réplica se apoya en la idea equivocada, ya discutida, de que el derecho positivo, tal y como lo entiende la teoría del derecho natural, no añade nada a las exigencias morales pre-existentes. Una vez que reconocemos que muchas exigencias jurídicas (¡no todas!) no serían exigencias morales de no haber sido jurídicamente creadas según los propios criterios de validez jurídica del derecho, podemos ver con facilidad el sentido que tiene decir que la condición de autoritativo del derecho, en el sentido focal de "autoritativo", no es otra cosa que su condición moral de autoritativo. Repitámoslo: la mayoría de nuestras leyes no tendrían autoridad moral de no ser leyes positivas, jurídicamente válidas. Así que su autoridad moral es también verdadera autoridad jurídica. Las leyes que, por su injusticia, carecen de la condición moral de autoritativas, no son jurídicamente autoritativas en el sentido focal de "autoritativo". Su "autoridad" es, en último término, nada más que la "autoridad" de la banda de malhechores, de la gente con poder que puede obligar a cumplir su voluntad so pena de desagradables consecuencias, pero que no puede crear lo que cualquier persona que se respete a sí misma consideraría una auténtica obligación.

La estrategia fundamental de la teoría del derecho natural para explicar la autoridad del derecho apunta a la infra-determinación (muy lejos de la pura indeterminación) de la mayoría, 
si es que no de todas, las exigencias de la razón práctica en el ámbito de la auto-determinación trascendente (no simplemente tecnológica) de las personas y las sociedades. En realidad, cuanto mejores y más inteligentes sean las personas, más esquemas de coordinación social (incluyendo siempre la coordinación "negativa" de la mutua tolerancia) a nivel político — propiedad, moneda, defensa, procedimiento jurídico, etcétera-, buenos pero incompatibles (que no pueden coexistir), propondrán. Así, al ser prácticamente inalcanzable la unanimidad respecto de los méritos de esquemas particulares, pero ser necesaria para el bien común (la justicia, la paz y el bienestar) la coordinación según algún o algunos esquemas, estas buenas personas tienen razón suficiente para reconocer la autoridad, esto es, un procedimiento aceptado y aceptable para elegir esquemas de coordinación particulares con los que, una vez así elegidos, cada miembro razonable de la comunidad está moralmente obligado a cooperar precisamente porque han sido elegidos - es decir, precisamente como jurídicamente obligatorios para la conciencia moralmente correcta-

Este es el origen de la independencia material y la perentoriedad que Hart, con toda razón, reconocía en su obra tardía como características de las razones jurídicas para la acción, y como la esencia de su condición autoritativa. ${ }^{37} \mathrm{Y}$, como muestra la explicación, esta independencia material y esta perentoriedad no son incondicionales ni sin excepción. Un grado suficiente de injusticia material negará la perentoriedad - en-conciencia- Con el debido respeto a Coleman y Leiter, las leyes de Sudáfrica, o algunas de ellas, no eran vinculantes, a pesar de que comúnmente se las considerase y tratase e impusiese como vinculantes.

El positivismo, coherentemente, no llega nunca más que a informar de las actitudes y de la concurrencia del comportamiento (puede que de las actitudes sofisticadas y articuladas que constituyen el conjunto de reglas de reconocimiento, cambio y adjudicación). No tiene nada que decir a los funcionarios o a los

37 Véase Hart, H. L. A., Essays on Bentham: Studies in Furisprudence and Political Theory, Oxford, Clarendon Press, 1982, pp. 243-268. 
ciudadanos particulares que quieren juzgar si, cuándo y por qué, la autoridad y la obligatoriedad pretendidas e impuestas por aquellos que están actuando como funcionarios de un sistema jurídico y por sus directrices son de verdad razones autoritativas para su propia acción en conciencia. El positivismo no hace más que repetir (l) lo que cualquier abogado competente - incluyendo todos los partidarios de la teoría del derecho natural jurídicamente competentes - diría que son (o que no son) leyes intra-sistemáticamente válidas, que imponen "exigencias jurídicas", y (2) lo que cualquier prudente observador de la calle advertiría que son las consecuencias probables del incumplimiento. No puede explicar la condición autoritativa, para la conciencia (el juicio racional último) de un funcionario o de un ciudadano particular, de estas supuestas e impuestas exigencias, ni de su carencia de tal autoridad cuando son radicalmente injustas. El positivismo es, en último análisis, redundante.

A pesar de toda su sofisticación, el positivismo contemporáneo no puede superar la postura adoptada por Austin en su brutal explicación de la condición autoritativa de las leyes inicuas: si digo que las leyes gravemente contrarias a la moral no son vinculantes, "el tribunal de justicia demostrará la falta de carácter convincente de mi razonamiento colgándome, en aplicación de la ley cuya validez he impugnado". ${ }^{38}$ Lo que es más importante es que la explicación de Austin es absurdamente irrelevante para las preguntas más serias que podrían plantearse acerca de la autoridad del derecho, a ninguna de las cuales responde.

38 Austin, J., The Province of Furisprudence Determined (ed. de H. L. A. Hart), New York, Noonday Press, 1954, 1832. Véase, también, Finnis, J., Aquinas..., cit., p. 355. 


\section{LA “TRADICIÓN DE LA LEY NATURAL”*}

No tiene demasiado sentido hablar de una tradición de la ley natural, porque "ley natural" (en el contexto de la ética, la política, el derecho y la jurisprudencia) ${ }^{* *}$ significa simplemente el conjunto de proposiciones verdaderas que identifican los bienes humanos básicos, los requerimientos generales de la elección correcta y las normas morales específicas deducibles de estos requerimientos en cuanto tienen que ver con (o dependen de) los bienes básicos particulares. Pero sí existe una tradición de teoría y de teorización acerca de la ley natural (y la sentencia precedente, una concreción contemporánea de esta teorización, está en la misma línea de los clásicos de esa tradición). Esta "tradición de la teoría de la ley natural" tiene tres caracteres principales:

Primero: crítica y rechazo del escepticismo ético, del dogmatismo y del convencionalismo.

Segundo: esclarecimiento de la metodología de las teorías sociales descriptivas y explicativas (e.g., ciencia política, economía, jurisprudencia...).

Tercero: crítica y rechazo de las concepciones agregativas de lo correcto y lo justo (e.g., consecuencialismo, utilitarismo, de maximización de la riqueza, "proporcionalismo"...).

En el ámbito de la jurisprudencia, los cometidos de la tradición consisten en mostrar:

- cómo una comprensión del derecho presupone una comprensión práctica (i.e., una comprensión del objetivo, del

* Traducción de Carlos I. Massini-Correas.

** En este texto se traduce el término inglés jurisprudence (i. e., saber jurídico profesional, o lo que los juristas continentales llaman "ciencia jurídica") por "jurisprudencia", guardando el sentido que tiene la palabra inglesa $(\mathcal{N}$. del T.). 
bien) de la comunidad, la justicia y los derechos, y la autoridad - como razones de elección y acción-;

- cómo una definición (i. e., un resumen de la propia comprensión) del derecho puede y debe incluir una referencia a las funciones u objetivos morales del derecho (especialmente, pero no sólo, las ideas "procedimentales" del Estado de derecho), sin excluir por ello las normas inmorales de la percepción de los juristas acerca del estudio de la jurisprudencia;

- cómo las normas positivas se derivan de la ley natural (principios morales) en al menos dos formas diferentes;

- cómo las normas injustas, siendo normas, pueden crear a veces una obligación moral, pero carecen siempre de la autoridad moral (y, por lo tanto, parte del carácter) que las normas, en virtud de haber sido establecidas legalmente, tienen de modo característico.

\section{CONTRA EL ESCEPTICISMO ÉTICO, EL DOGMATISMO,} EL CONVENCIONALISMO

(a) Las negaciones escépticas de al menos un bien humano básico (verdad y conocimiento) son auto-refutatorias. La teoría de la ley natural es una teoría que trata de explicar el hecho de que realizarla (o cuestionarla) es algo que vale la pena. Las teorías que no tienen lugar para el hecho de su propia existencia, o para el valor de su misma prosecución, son auto-refutatorias.

(b) La mayoría de los escepticismos contemporáneos acerca de los bienes humanos básicos, y/o de los requerimientos de la razonabilidad práctica, están basados en un deslizamiento lógicamente ilícito (especialmente común en la era actual) desde "ser" a "deber". Por ejemplo:

- Yo tengo un sentimiento de aprobación de X; luego, X es bueno (es valioso... u obligatorio, o...). 
- Yo estoy comprometido, he adoptado, he optado por, he elegido, he decidido acerca de... el principio práctico $\mathrm{X}$...; luego, X debería ser hecho.

- En el pensamiento actual/la sociedad contemporánea, $\mathrm{X}$ es ampliamente visto como (no) bueno/obligatorio; luego, X es (no) bueno/obligatorio.

- X no es universalmente/comúnmente considerado como bueno/obligatorio; luego, X es (no) bueno/obligatorio.

Una teoría explícita de la ley natural fue emprendida por Platón y Aristóteles precisamente como una crítica de non sequiturs, como los anteriormente enunciados. Estos pensadores y sus seguidores, como Tomás de Aquino, respetan la distinción entre ser y deber, hecho y valor, mucho más cuidadosamente que, por ejemplo, David Hume. Las afirmaciones en contrario son mitos o incomprensiones. ${ }^{1}$

La crítica del escepticismo está estrechamente vinculada a la principal estrategia de la jurisprudencia contemporánea: atención, no meramente a la estructura externa, prácticas o aun sentimientos, sino más bien a las razones características que la gente tiene para actuar de aquellos modos que conduzcan a la constitución de fenómenos sociales específicos (como el derecho). La jurisprudencia se ocupa de los tipos de justificación para las decisiones.

Nota: estando interesada en la verdad, la teoría de la ley natural es completamente distinta de los movimientos políticos, ya sean conservadores, liberales, radicales, o los que sean.

\section{SOBRE LA METODOLOGÍA DE LAS CIENCIAS SOCIALES}

Puede ser mostrado conclusivamente que la "jurisprudencia analítica" o la "sociología descriptiva del derecho", emprendida por

1 Para la verificación textual de las dos últimas afirmaciones, véase Finnis, John, Natural Law and Natural Rights, Oxford \& New York, 1980, 330-38, 470-78, 53-55. 
Bentham, y desarrollada por Austin, Kelsen, Weber, Hart, Raz y otros, escapa de la arbitrariedad metodológica sólo presuponiendo ciertas valoraciones en su selección y/o formación de los conceptos a usar en sus análisis, descripciones y desarrollos. Pero ella tiende hacia la arbitrariedad en la medida en que (en el caso de Bentham, Austin y Kelsen) renuncia o suprime estas valoraciones, o bien (en el caso de Weber y Hart), las asumen como indiscutibles opciones o presupuestos. ${ }^{2}$

La teoría de la ley natural reconoce plenamente el lugar de las ciencias sociales descriptivas/explicativas (de las cuales la mayor parte de la Política de Aristóteles es un modelo temprano), muy distinto del razonamiento práctico crítico-justificatorio acerca de lo bueno y lo correcto en los agrupamientos sociales. Pero la teoría de la ley natural sostiene que la formación y selección de conceptos para las descripciones y explicaciones sociales está y debe estar (salvo que haya de permanecer pueblerina) guiada por las evaluaciones que una reflexión crítica sobre la situación humana muestre como críticamente justificadas.

En resumen, la teoría de la ley natural trata de realizar abiertamente, críticamente y a través de la discusión, aquello que la mayoría de los demás pensadores analíticos y descriptivos realizan de modo encubierto y dogmático. Una vez que se reconoce el método de definición utilizado por Aristóteles (entre casos centrales y casos secundarios, tal como son juzgados por personas de razonabilidad práctica), se puede ver que su metodología de las ciencias sociales (en cuanto distinta de algunas de sus historiográficamente primitivas aplicaciones) es enormemente más sofisticada y más abierta a los datos frescos y a la mejor comprensión que muchas de las obras más modernas en esos campos.

2 Véase Finnis, supra nota 1, capítulo I; y Finnis, John, "On «Positivism» and «Legal Rational Authority»”, 5 Oxford F. Legal St., 1985, 74-90. 


\section{GRÍTICAS A LAS TEORÍAS AGREGATIVAS}

DEL DERECHO

Más importante (para la ética, la teoría política y la jurisprudencia) que la consideración de los bienes humanos básicos, es la explicación del segundo nivel de reflexión ética, que identifica los "requerimientos de razonabilidad práctica" o "modos de responsabilidad". La mayoría del pensamiento ético y jurídico moderno asume acríticamente que la razonabilidad requiere la agregación de bienes o valores. Pero más allá de los contextos establecidos por objetivos simples (proyectos, o la realización de compromisos sencillos), no hay, en situaciones de elección moral o política significativas, un bien netamente superior o un mal menor susceptibles de ser identificados por cálculos o evaluaciones agregativas. Esto es, la convicción de que esto no es solamente quimérico prácticamente, sino incompatible con la libre elección e incoherente.

Los derechos humanos, e instituciones como el Estado de derecho, revisten justificadamente la configuración que tienen en la medida en que los métodos ético/políticos agregativos son injustificables. Los principios kantianos de imparcialidad y respeto por la "humanidad" son mucho más razonables que los varios utilitarismos, pero estos principios necesitan (y pueden alcanzar) el sustento de la descripción de la naturaleza humana ("humanidad") —y de los principios prácticos básicos - provista por la comprensión de los bienes humanos básicos.

$\mathrm{Al}$ ir más profundamente que las teorías contractualistas de la autoridad, o que las teorías voluntaristas del contrato, una teoría de la ley natural puede dar una mejor explicación de los problemas tradicionales de la jurisprudencia, tales como la formación de las costumbres obligatorias (como en el derecho internacional), la continuidad del derecho a través de las revoluciones, la autoridad de los gobiernos de facto, las relaciones entre las contractuales y otro tipo de obligaciones, las relaciones entre la responsabilidad extracontractual y otros esquemas para reparar pérdidas, etcétera. 


\section{UNA NOTA SOBRE LA ENSEÑANZA \\ DE LA JURISPRUDENCIA}

La jurisprudencia, me parece, puede muy bien ser introducida en los cursos de Introducción al Derecho:

- Para mostrar cómo los estándares procedural/constitucionales del Estado de derecho (bien expuestos en Fuller, The Morality of Law, caps. II y VI) relacionan al derecho (y a nuestro derecho) con la teoría política (y con las creencias y compromisos de nuestra política), y resultan en normas jurídicas e instituciones altamente específicas y problemáticas;

- Para mostrar cómo las instituciones del derecho privado, como la responsabilidad extracontractual, los contratos o la quiebra, representan concepciones morales elaboradas en parte por la aplicación, en parte por la determinación (constructiva, no-deductiva, y en ese sentido "libre", implementación o especificación de nociones generales) y en parte por consideraciones de consistencia que son al menos parcialmente deductivas. ${ }^{3}$

Los cursos dedicados a la "jurisprudencia" necesitan abordar frontalmente las cuestiones metodológicas sugeridas más arriba como el marco para una reflexión fructífera sobre el trabajo de juristas específicos (importa bastante menos cuál de los juristas sustanciales, vivos o muertos). Reflexionar sobre estas cuestiones es reflexionar sobre la "teoría de la ley natural"; por supuesto, ello es así (cualesquiera sean las etiquetas que se favorezcan $h a-$ ciendo teoría de la ley natural) salvo que se esté determinado de antemano a que las respuestas hayan de resultar a favor del escepticismo, o del "convencionalismo de personas modernas", o del provincianismo metodológico, o de alguna teoría de la justicia meramente agregativa.

3 Véase, e.g., las reflexiones sobre el derecho de quiebras en Finnis, supra nota 1 , pp. 188-93. 


\section{ARISTÓTELES, SANTO TOMÁS Y LOS ABSOLUTOS MORALES}

En la mitad exacta de su Natural Right and History, entre las páginas 160 y 162 de las 323 que tiene el libro en las ediciones originales inglesa y norteamericana, y en el núcleo de su discusión sobre el tipo central (el aristotélico) de los "tres tipos de doctrinas clásicas de derecho natural", ${ }^{1}$ Leo Strauss ha propuesto una enseñanza centrada en su propio pensamiento e influencia.

Su desarrollo comienza como si estuviera explicando a Aristóteles, pero, manifiestamente, va más allá de ese pensamiento hacia el suyo propio:

Toda acción está relacionada con situaciones particulares. En consecuencia, la justicia y el derecho natural residen, por decirlo así, más en las decisiones concretas que en las reglas generales... En cada conflicto humano existe la posibilidad de una decisión justa basada en la completa consideración de todas las circunstancias, decisión requerida por la situación. El derecho natural, así comprendido, es obviamente mutable. Más aún, difícilmente se puede negar que en todas las decisiones concretas, los principios generales están implícitos y presupuestos. Aristóteles reconoce la

* Traducción de Carlos I. Massini-Correas, Universidad de Mendoza, Argentina. Publicado originalmente en Persona y Derecho, Pamplona, núm. 28, 1993.

1 Strauss, Leo, Natural Rights and History (una extensa versión de las conferencias Charles R. Walgreen, dadas en octubre de 1949), University of Chicago Press, 1953, p. 146. Ésta y las páginas que serán citadas pertenecen al capítulo central del libro, cuando consideramos la introducción y las dos mitades de los capítulos V y VI, respectivamente. 
existencia de tales principios, por ejemplo: de justicia "conmutativa" y "distributiva"... El bien común consiste normalmente en lo que es requerido por la justicia conmutativa y distributiva o por otros principios morales de esta especie o en lo que es compatible con estos requerimientos. Porque, por supuesto, el bien común abarca la mera existencia, la mera supervivencia, la mera independencia de la comunidad política en cuestión. Llamemos "situación extrema" a una situación en que está comprometida la verdadera existencia o la independencia de una sociedad. En situaciones extremas puede haber conflictos entre lo que requiere la propia preservación de la sociedad y los requerimientos de la justicia conmutativa y distributiva. En tales situaciones, y solamente en tales situaciones, se puede decir justamente que la seguridad pública es la ley suprema. Una sociedad decente no irá a la guerra excepto por una causa justa. Pero lo que haga durante la guerra dependerá, hasta cierto punto, de lo que el enemigo - probablemente un enemigo absolutamente inescrupuloso y salvaje- lo fuerce a hacer. No hay límites asignables a lo que pudieran llegar a ser represalias justas. Pero la guerra arroja su sombra sobre la paz... Las sociedades están amenazadas no solamente desde afuera. Las consideraciones que se aplican a los enemigos extranjeros pueden ser muy bien aplicadas a los elementos subversivos dentro de la sociedad. Dejemos estas tristes exigencias cubiertas con el velo con que justamente están cubiertas. Es suficiente repetir que, en situaciones extremas, las reglas normalmente válidas del derecho natural quedan justamente cambiadas en concordancia con el derecho natural; las excepciones son tan justas como las reglas. ${ }^{2}$

La conclusión es que Platón y Aristóteles lograron evitar tanto la scylla del "absolutismo" como el Carybdis del "relativismo", ${ }^{3}$ pero no así Santo Tomás.

Strauss anticipa así notablemente los principales temas de la crítica que, en los cuarenta años siguientes, iba a ser dirigida por ciertos católicos contra las enseñanzas de la moral cristiana que el Aquinate ayudó a transmitir. Estos son los temas: el juicio

\footnotetext{
2 Ibidem, pp. 159 y 160.

3 Idem.
} 
moral tiene su verdad solamente en y para "situaciones particulares"; en situaciones de "conflicto" se podría hablar de un "bien común" particular que relativiza los principios de justicia y suspende ciertas "reglas de derecho natural"; no hay una sola regla (moral)... que no esté sujeta a excepción; ${ }^{4}$ lo que importa últimamente no es lo que se hace, sino que se haga con una cierta "actitud", por ejemplo: de "renuncia". Cualquiera que sea el éxito de Strauss en articular el espíritu de "los clásicos", ciertamente transmite algunos elementos del espíritu de la mitad y fin del siglo veinte.

Además, este pasaje de Strauss debe ser tomado como una estudiada defensa de la "guerra total", política practicada por los aliados en la guerra que terminó solamente cuatro años antes de las conferencias de Strauss y que fue extendida a la seguridad política de posguerra en Occidente. La disuasión nuclear trata a la "situación extrema", en un aspecto decisivo, como lo simplemente "normal". ${ }^{5}$ En realidad, lo que Strauss está enseñando es que una sociedad cuya "mera independencia" está amenazada por un enemigo injusto está justificada si ejecuta represalias ilimitadas y otros actos admitidamente contrarios a la justicia conmutativa. Para el Aquinate (que inventó el uso de "conmutativo"), la justicia conmutativa es aquella justicia cuyo verdadero primer componente es la absoluta exclusión de matar intencionadamente inocentes. ${ }^{6}$ Pero Strauss es en rigor un representante de los

\footnotetext{
4 Ibidem, p. 161.

5 Crosey, Joseph y Strauss (eds.), The History of Political Philosophy, y discípulo relacionado con la edición de los Festschrift para el 65 cumpleaños de Strauss, publicó en 1961, "The moral Basis of International Action" (en su Political Philosophy and the Issues of Politics, University of Chicago Press, 1977, pp. 172-188, esp. 184-5), una justificación de la disuasión nuclear sobre una base que, en la literatura académica, parece estar más cerca de apoyarse simplemente en el eslogan "antes muerto que rojo", sin olvidar la esencia de la política que él defiende: "Si tenemos que morir en manos de los rojos, no será sin una represalia ilimitada y sin trabas".

6 Summa Theologiae, II-II, q. 64, a. 2, ad 3; a 6. La q. 64 es la primera de las quince cuestiones y sesenta y cinco artículos dedicados a la justicia conmutativa.
} 
modernos, que dan por sentado que el principio de Caifás es el correcto: es mejor que un hombre - o unos pocos hombresmueran injustamente a que perezca todo el pueblo. Frente a esta cuestión moral decisiva, las diferencias entre Strauss y Voegelin, o Arendt, o Rawls, o Nagel, o Dworkin u otros incontables, simplemente desaparecen. Todos rechazan los absolutos morales a los que nuestra civilización rendía hasta ayer acatamiento, por lo menos de labios para afuera.

Strauss proclama que esta enseñanza, representativa de la modernidad, es también el punto de vista de Aristóteles y un camino medio seguro entre los extremos del convencionalismo de Averroes y el absolutismo tomista. ${ }^{7}$ Pero, ¿qué es lo que de hecho pensaba Aristóteles? Strauss se apoya en un solo texto, en una o dos líneas, más bien coyunturales, de la Ética a Nicómaco, V, 7: "aunque lo justo sea, por naturaleza, aquello que en cualquier parte tiene la misma fuerza" es "completamente mudable".

Ahora bien, se encuentran en el Aquinate afirmaciones parecidas, aparentemente universales u omniabarcantes. Me referiré a dos ejemplos importantes. El primero es que los principios morales comunes primarios son verdaderos para todos en cualquier parte, pero las "conclusiones particulares" son verdaderas sólo para la "mayor parte" de los casos (ut in pluribus), con excepciones (ut in paucioribus), porque cuanto más se acerca uno a lo particular,

7 Los lectores cuidadosos no tomarán este discurso de vía medía demasiado seriamente porque el propio punto de vista de Strauss coincide exactamente con lo que atribuye a los averroístas (incluyendo a los aristotélicos islámicos y judíos): las reglas morales presentadas por la sociedad como universalmente válidas son, en verdad, sólo generalmente válidas, de modo que presentadas sin cualificaciones ni excepciones son falsas, y por ello no naturales sino convencionales. 
con lo que toda acción está relacionada, tanto más los principios generales se vuelven inadecuados. ${ }^{8}$

Pero esta afirmación es en sí misma sólo una generalización. Se aplica a la mayoría de los principios morales y normas, ya que la mayoría son indicaciones afirmativas que especifican la responsabilidad "de hacer algo", tal como devolver lo que se ha pedido prestado. Pero no se aplica a las pocas pero vitales normas morales negativas, de las que en cada situación se requiere una, por ejemplo "no elegir matar al inocente", "no mentir o cometer adulterio o sodomía". Estos preceptos obligan siempre y en cada situación (semper et ad semper). Nunca es posible cometer un robo o un adulterio. Pero los preceptos afirmativos, aunque siempre obligan, no lo hacen en cada situación, sino que sólo en relación al tiempo y lugar (semper sed non ad semper, sed pro loco et tempore) $;{ }^{9}$ así, no se debería devolver lo que uno ha pedido prestado si se tratara de un arma mortal y quien la prestó se hubiera vuelto loco o traidor. ${ }^{10}$ Para repetirlo una vez más, la afirmación "las reglas morales son una generalización, no universalmente verdadera" es sólo una generalización, no universalmente verdadera.

Hay un segundo conjunto de afirmaciones en las que el Aquinate parece tratar a todas las normas morales específicas como sujetas a excepciones. Efectivamente, lo encontramos diciendo que los mandamientos de la segunda tabla del Decálogo (por ejemplo: no matar, no cometer adulterio, no robar) están sujetos a la dispensa divina, en aquellos casos excepcionales en que Dios milagrosamente comunica su voluntad para permitir matar, adulterar, y así sucesivamente. ${ }^{11}$

8 S. Th., I-II, q. 94 a. 4c; en el ad. 2, el Aquinate agrega que lo afirmado en Et. Nic., V, 7, sobre que el derecho natural es "mudable" significa justamente eso.

9 Aquino, Tomás de, Ad Rom., a. 13, lect, 2; también III Sent, d. 25, a. 1 b ad.3; IV Sent, d. 17, q. 3, a. 1 d, ad. 3; Q. D. de Virt. III, a. 1 c y ad. 4; De Malo, q. 7, a. 1 ad. 8; S. Th., II-II, q. 33, a. 2c.

10 S. Th., I-II, q. 94, a. 4c. Ese es el ejemplo dado para ilustrar el ut in pluribus, carácter de (la mayoría de) las normas morales.

11 I Sent., d. 47, q. 1, a. 4; II Sent., d. 33, q. 1, a. 2; De Malo, q. 3, a. 1, ad. 17. 
Algunos teólogos quieren hacer de estos pasajes el fundamento para tomar el "camino medio" de Strauss. Pero la enseñanza del Aquinate es diferente. Siempre que él considera, directa y formalmente, si Dios puede dispensar del Decálogo, la respuesta del Aquinate es clara: no puede haber dispensa para ninguno de los últimos siete mandamientos. ${ }^{12}$

Esto no supone una contradicción. En el conjunto de pasajes mencionados primero, donde incidentalmente cita la dispensa divina, el Aquinate está considerando el "comportamiento físico" involucrado en los actos humanos de matar, tener relaciones sexuales o tomar la propiedad ajena; si los mandamientos son considerados como simplemente recayendo sobre comportamientos de ese tipo o sobre alguna descripción "convencional" de ellos, entonces el comportamiento que normalmente (o bajo una descripción convencional) está prohibido puede ser y excepcionalmente ha sido divinamente permitido. Pero la moralidad, hablando estrictamente, no tiene nada que ver con el comportamiento físico como tal (ni con sus descripciones, meramente convencionales), sino con el comportamiento físico en cuanto "humanamente elegido e intentado", es decir, con "actos humanos". ${ }^{13}$ Considerados en tanto pesan sobre los actos humanos, los mandamientos no tienen excepciones y no pueden ser dispensados ni aun por Dios (porque la bondad de Dios y su santidad son incompatibles con que pueda querer ningún mal). Aquellas ocasiones en que - en la exégesis aceptada por Santo Tomás - Dios parece hacer una excepción a los mandamientos son en realidad situaciones en las que Dios cambia de tal modo las condiciones o las circunstancias del comportamiento, que lo que es humanamente deseado, elegido o intentado, no es una acción de matar al inocente, sino de efectuar la justicia divina sobre los culpables; no una acción de tener relaciones sexuales con

12 III Sent., d. 37, q. un. a. 4c y ad. 1; S. Th., I-II, q. 100, a. 8.

13 I Sent., d. 36, q. un, a. 5, ad. 5; d. 40, q. un, a. 1, ad. 4; a. 2c y ad. 3; IV Sent., d. 16, q. 3, a. lb, ad. 2; De Malo, q. 2, a. 4c y ad. 9; S. Th., I-II, q. 1, a. 3, ad. 3 ; q. 20, a. 2c. 
una mujer que no es su esposa, sino relaciones con una mujer hecha esposa divinamente por Dios, y no un acto de robo, sino de tomar posesión de lo que Dios había hecho ya su propiedad personal. ${ }^{14}$

De esta manera, las afirmaciones "puede haber dispensas al Decálogo", así como "las normas específicas pueden tener excepciones", son sostenidas por el Aquinate sólo con una cualificación tácita. Así, "el Derecho Natural es totalmente mudable" de Aristóteles tal vez esté pensado para ser tomado igualmente con una inexpresada cualificación.

En la Ética a Nicómaco, II, 6, al definir las acciones, las pasiones y las disposiciones correctas como intermedias entre los excesos, Aristóteles añade:

Pero no cada acción ni cada pasión admite un medio, porque algunas tienen nombres que ya implican maldad, por ej.: rencor, desvergüenza, envidia y, en el caso de las acciones, adulterio, robo, asesinato ...No es posible, entonces, estar nunca en lo correcto con respecto a ellas; se está siempre en el mal.

La bondad o la maldad, con respecto a tales cosas, no dependen de cometer adulterio con la mujer correcta, en el tiempo correcto y en la forma correcta, sino que simplemente hacer cualquiera de estas cosas es hacer el mal [Et. Nic., II, 6; 1107 a 9-17].

La interpretación académica realizada por W. F. R. Hardie sobre este pasaje, característica de la mitad del siglo veinte, asegura que Aristóteles está realizando

una precisión puramente lógica, que surge del hecho que ciertas palabras son usadas... como implicando, como parte del significado de la palabra, que son excesivas o defectivas y por lo tanto erróneas...; no tiene sentido preguntar cuándo un asesinato es bueno, porque llamar "asesinato" a matar es decir que está mal.... Esto y no otra cosa es lo que Aristóteles quiere decir. ${ }^{15}$

14 Cfr. P. Lee, "Permanence of the Ten Commandments: St. Thomas and his modern commentators", Theological Studies, 42, 1981, 422-43.

15 W. F. R. Hardie, Aristotle's Ethical Theory, Oxford, 1968, 137. 
Esto es como si Aristóteles se anticipara a los teólogos que dicen que el Decálogo meramente nos exhorta a través de formulaciones formales y tautológicas a abstenernos de cualquier cosa que sabemos que, de cualquier manera, está mal: no matar malignamente, no tener relaciones con la persona que no corresponde o en la ocasión no indicada. Para estos teólogos, la protesta de San Pablo en contra de hacer el mal en favor del bien (Rom. 3, 8) significa meramente "no hagas el mal moral en favor del bien no moral”; o, en su lenguaje moral, "¡no elijas, en consideración a un bien globalmente mayor, un bien globalmente menor!".

Hardie no ofrece ningún argumento y permanece en silencio sobre las palabras "la bondad o la maldad, con relación a tales cosas, no dependen de cometer adulterio con la mujer correcta, en el tiempo correcto y en la forma correcta". Nos permite suponer que Aristóteles estaría de acuerdo con que uno puede, por supuesto, en las circunstancias correctas (tal vez excepcionales), tener relaciones con alguien que no sea su esposa. Si ello es así, Aristóteles eligió ciertamente un camino equivocado para expresarse. El pasaje paralelo de la Ética a Eudemo, no mencionado por Hardie, parece aún menos "puramente lógico"; "un hombre no es un adúltero por tener relaciones con mujeres casadas más de lo que debiera (no hay tal cosa); eso es siempre un vicio". ${ }^{16} \mathrm{Y}$ en el mismo texto, Aristóteles anota que la gente acusada de adulterio admitirá haber tenido relaciones sexuales con una mujer casada, pero negará que haya sido adulterio, alegando que fueron forzados por razones de necesidad.

La compulsión o la necesidad (Aristóteles los trata como sinónimos) es el tema de otro pasaje que aparentemente se refiere a los absolutos morales (Et. Nic., III, 1). Está discutiendo "involuntariamente" las pasiones y las acciones y se pregunta si hay involuntariedad cuando se hace "algo ruin" (aischron, en latín, turpe), por temor a males mayores o por un noble fin; por ejemplo, "si un tirano le ordena a alguien hacer algo ruin, teniendo a sus

16 Ética a Eudemo, II, 3, 1221b, 20-22. 
padres o hijos en su poder, bajo la amenaza de que si él hiciera la acción, éstos serían salvados, pero de otra manera se les daría muerte ..." (1110 a 4-7).

¿Cuáles son los actos ruines que Aristóteles acepta que se pueden elegir laudablemente por un objeto noble y grande? Aspaso, uno de los primeros comentaristas de Aristóteles (c. 200 a. C.), abre la línea de interpretación adoptada, independientemente, por el Aquinate. Lo que Aristóteles tenía en mente en esta ocasión, dicen ellos, no eran actos moralmente malos, sino meramente "ignominiosos". ${ }^{17}$ Así, dice Aspaso, sería recomendable obedecer a un tirano que amenazara con destruir la propia ciudad y familia a menos que el mandato fuese de llevar públicamente ropas del otro sexo. ${ }^{18}$

Pero el anónimo Viejo Escoliasta (¿200 a. C.?) ofrecía una interpretación que, todavía más que el texto de Aristóteles, forzaba a los cristianos del medioevo a aclarar su propia enseñanza moral, ya clara a pesar de la incapacidad de comprensión de los revisionistas del siglo veinte. El Viejo Escoliasta ofrece un ejemplo de "actos ruines" dignos de alabanza: tener relaciones sexuales con la esposa de otro con el fin de derribar a un tirano. El mal moral, añade, reside no en los actos, sino en sus "intenciones". Así, podríamos establecer su punto de vista en que el fin justifica los medios. ${ }^{19}$

Roberto Grosseteste, arzobispo de Lincoln, introdujo al Viejo Escoliasta en la cristiandad latina. En este punto del comentario, intercaló una de sus infrecuentes notas personales:

La religión cristiana declara y sostiene que el pecado no debe ser cometido ni por perseguir algún bien (utilitas) ni para evitar la ignominia. De esta manera, ya que es pecado mentir y pecado tener relaciones sexuales con la esposa de otro (alienae uxori misceri),

17 Aquino, Tomás de, In Ethicorum, N. 393 y 394.

18 Aspasius, en Heylbut (ed.), Commentaria in Aristotelem Graeca, Berlín, 1889, vol. 20,61 .

19 Heylbut (ed.), Commentaria in Aristolelem Graeca, Berlín, vol. 20, 1892, 142. 
esto no debe hacerse por ningún motivo. De esta manera, la enseñanza dada más arriba no es una doctrina sino un error por los ejemplos que propone. Porque (y aquí se hace eco de la Vulgata de San Pablo en Romanos 3, 8) los males del pecado no deben ser hechos para alcanzar otros bienes. Por otra parte, los males del sufrimiento o del castigo (poena) aunque sean verdaderamente vergonzosos (turpia), teniendo en cuenta que no son pecaminosos, se pueden hacer y tolerar por causa de otros bienes. ${ }^{20}$

Tomás de Aquino, escribiendo casi treinta años después, fue terminante y bien conciso; él expone el siguiente argumento, destinado a demostrar que el sexo, fuera del matrimonio, no puede ser sino intrínsecamente malo (pecata ex genere, o secundum se): "lo que es pecaminoso no debe hacerse por ningún motivo, aunque sea bueno, como Pablo dice en Romanos 3, 8... Pero dice el Comentador en la Ética: un hombre recto comete adulterio con la esposa de un tirano para que el tirano pueda ser muerto y el país liberado. Por lo tanto, el adulterio no es intrínsecamente malo; mucho menos cualquier otro acto de fornicación" (De Malo, q. 15, a. 1, arg. 4).

\section{¿La respuesta del Aquinate?}

"El Comentador no debe ser apoyado en este punto: porque no se puede cometer adulterio por causa de ningún bien (pro nulla enim utilitate debet aliquis adulterium commitere), lo mismo que no se puede decir una mentira para obtener alguna ventaja (propter utilitatem aliquam), como dice Agustín en su Contra Mendacium". ${ }^{21}$

20 Mercken, H. Paul F. (ed.), Corpus Latinum Commentarium in Aristotelem Graecorum, Brill, Leiden, 1973, VI, 1, 239 y también para una nota similar de Grosseteste sobre 1110 a. 1.

21 De Malo, q. 15, a. 1, ad. 4. La opinión del comentador (y del viejo escoliasta) es rebatida en términos similares por San Alberto, Super Ethica Commentum et Quaestiones (c. 1250-1252), Opera Omnia, SIV (I) (ed. W. Kuebel, Aschendorff, 1968), p. 125 (ad 1107 a 8-32), p. 380 (ad 1136 b 151137 a 30), citando a $R_{0}$ - 
Por lo tanto, desde Agustín en el siglo IV (por supuesto, desde antes de él, ya que en medio de la controversia Agustín trata esto como algo incontrovertido) hasta 1964, los términos como "adulterio" no fueron definidos por los grandes filósofos y teólogos como un uso inicuo del sexo. Más bien, al haber sido definido como, por ejemplo, el sexo que involucra a una persona casada con quien no está casada, será juzgado siempre como malo, en cualquier circunstancia, aun en el caso en que, por ejemplo, el "bien común" o la salus populi estuviesen comprometidos.

Y lo mismo sucede con el asesinato. El Aquinate lo define, en efecto, como la muerte intencional del inocente y argumenta que está completamente excluido por el quinto mandamiento y que es un acto intrínsecamente malo (secundum se malo). Tales actos, anota él, "no deben hacerse ni por un buen fin, tal como Agustín y Aristóteles lo aclaran". ${ }^{22}$ Porque su opinión acerca de Aristóteles está basada en aquel pasaje de la Ética, II, 6, que una interpretación moderna lee como exento de contenido ético. Para mí, el texto de Aristóteles no es lo suficientemente claro como para decidirse de modo definitivo entre las interpretaciones medievales y modernas. Pero al mencionar a Aristóteles junto a Agustín, sugiere el Aquinate que la no excepcionalidad de las normas morales absolutas es accesible al pensamiento filosófico y a la razón práctica reflexiva, aun sin ayuda de la divina revelación.

¿Es esto asi?

Aunque no lo haya negado claramente, Aristóteles no afirma nunca la no excepcionalidad de las normas morales. Y esto no

manos, 3, 8 y Contra Mendacium, c. 9, y p. 142 (ad N.E., III, 1). El argumento de Agustín sobre los absolutos morales en el Contra Mendacium llegó a ser modelo general por medio de las Sentencias de Pedro Lombardo, II, d. 40.

22 S. Th.,II-II, q. 64, a. 2, obj. 3 y ad. 5. 
es sorprendente. Salvo que se hayan realizado ciertas aclaraciones, afirmarla significa estar afirmando que hay situaciones en las que uno se enfrenta a un verdadero "conflicto de deberes", queda estrictamente perplejo y no puede dejar de obrar mal. Las aclaraciones necesarias para evitar este absurdo moral son las siguientes: i) dentro del complejo representado por el comportamiento, los resultados y las causas de la propia elección, se puede ser capaz de distinguir qué es lo elegido, es decir, intentado (ya sea como medio o como fin), y qué es lo que está previsto, causado y aceptado, pero no intentado; ii se debe notar que las acciones excluidas por las normas morales absolutas están descritas en términos de lo que se intenta como fin o como medios, no en términos de fracciones de comportamiento físico como tal ni en términos de otros resultados previstos (pero no intentados); iii) se debe estar capacitado para decir por qué la exclusión de ciertas intenciones, de fines o de medios y las acciones físicas que ejecutan esas intenciones, es moralmente importante. Para hacer esto se necesitará, a la vez, iv) una estimación de los bienes humanos que proveen las razones últimas para las elecciones, y v) una concepción de la libre elección como el compromiso propio con fines y medios identificados en una propuesta que se adopta para sí sin estar determinado, además, por ningún factor, cualquiera que éste sea (ya sea la razón o el deseo).

Aunque ninguno de estos desiderata es negado por Aristóteles, y los elementos de cada uno de ellos están diseminados en sus obras, ninguno es claramente afirmado. En el Aquinate, por el contrario, cada uno de ellos está afirmado y, de alguna manera, explicado y justificado. Pero no están presentados conjuntamente en una relación, ordenada y accesible, del sentido y de la fuerza racional de los absolutos morales. Tampoco los seguidores del Aquinate suplieron esta sistematización ausente. Por ello, ha llegado a ser común proclamar que los absolutos morales, incluyendo el asesinato, el adulterio, el robo, etcétera, están intuidos como principios absolutamente básicos, primarios e inderivados, en ese hábito de los primeros principios que el Aquinate llama synderesis. 
Nadie puede, por lo tanto, condenar a Strauss por adjudicar este punto de vista al Aquinate. Pero, ciertamente, no es el punto de vista de Tomás de Aquino, porque el Aquinate establece muy claramente que las normas morales de la forma y contenido del Decálogo no son principios primarios no-derivados o per se nota, sino más bien conclusiones de verdaderos principios previos, no derivados o per se nota. ${ }^{23}$ Pero si esto es así, necesitamos una explicación del primer principio moral (o principios morales) de los que están derivadas estas conclusiones.

Ofrecer esa explicación, en un esfuerzo filosófico libre, apto para ser juzgado en su propio nivel, es el intento del núcleo de la teoría ética ensayada en estos últimos veinticinco años por Germain Grisez, Joseph Boyle, yo mismo y otros. Nuestra teoría, tal como permanecía en 1986, está sintetizada en los capítulos 10 y 11 de nuestra obra Nuclear Deterrence, Morality and Realism (Oxford U. P., 1987). Aquí mencionaré solamente unos pocos puntos clave.

La acción es inmoral cuando va contra la razón. Ahora bien, la elección de la acción será contra la razón si es que hay una razón en contra de realizar esa acción y no hay una razón racionalmente preferible para realizarla. Entre las diferentes razones posibles contra una elección, una puede ser la siguiente: que la opción implique el propósito de perjudicar o impedir alguna determinación de un bien humano básico (no-instrumental o intrínseco), algún aspecto irreductible del bienestar de una persona humana, tales como la vida del cuerpo, el conocimiento de la verdad, la armonía con las demás personas y otras por el estilo. Ahora bien, en cualquier situación en que tal acción pueda ser elegida, ninguna "razón" para elegirla puede ser racionalmente preferible a la razón en contra de esa elección.

23 P. ej.: S. Th., I-II, q. 95, a. 2c; q. 100 a. lc, 3c. y ad. 1, 6c, llc y ad. 1; también q. 94, a. 6c. Véase Finnis, J., "Natural Inclination and Natural Rights: Dcriving «Ought» from «is» According to Aquinas", en Elders y Hedwig (eds.), Lex et Libertas: Freedom and Law according to St. Thomas Aquinas, Vatican City, 1987, 43-45 a 52-3. 
Porque si hubiera una razón (para hacer $\mathrm{x}$ ) que un método racional de comparación identificara como preferible (antes del juicio moral), la razón alternativa (en contra de hacer x), así identificada como racionalmente inferior, cesaría de ser racionalmente aprobable, al menos con respecto a esa situación de elección. La razón así identificada como preferible y la opción favorecida por esa razón quedarían sin oposición racional. No quedaría la posibilidad de una elección racionalmente motivada y moralmente significativa entre opciones alternativas. Porque es posible una elección racionalmente motivada justamente donde se tienen realmente razones para las opciones alternativas; entonces la elección es moralmente significativa porque es libre, no siendo un factor cualquiera, sino la elección en sí misma, la que establece qué alternativa es la elegida.

Así, la razón por la que hay elecciones moralmente significativas es, precisamente, porque antes del juicio moral no existe un método racional de identificación de las razones para las opciones alternativas como racionalmente superiores o inferiores. Porque las concreciones de los bienes humanos básicos, concreciones consideradas precisamente como razones para el juicio y la acción moral, son inconmensurables unas respecto a otras. Y esto no debe sorprender, porque esas concreciones no son otra cosa que aspectos de las personas humanas, presentes y futuras, y las personas humanas no pueden ser sopesadas ni balanceadas.

Entre los factores que componen esta inconmensurabilidad racional, pre-moral, de las opciones moralmente significativas, está la reflexividad de la libre elección en sí misma. Las elecciones, al no estar determinadas por ninguna otra cosa salvo el acto de elección del que elige reflexivamente, forman el carácter del que elige, su personalidad, su alma. Las elecciones, de hecho, perduran; persisten en el elector hasta que, si esto sucede, son revertidas por una elección contraria. ¿Cómo se podría valorar sensatamente el total neto del valor pre-moral y del disvalor de ese cambio y de los cambios de actitud, hechos y prácticas que resultan a menudo de una sola elección? Esta especie de consecuencia no puede, 
simplemente, ser mensurada con las otras consecuencias de la elección.

Por otra parte, el Aquinate nunca busca resolver una cuestión moral identificando una opción como un mal menor. Él rechaza, donde quiera que sea, el intento de resolver los problemas morales por medio de ese principio, que el final del siglo veinte, incluyendo sus epígonos teológicos, trata como el autoevidente mayor principio de la moralidad (o al menos, como el principio moral patrón en "situaciones conflictivas"): jelige el mal menor! Aunque nunca discute el tema, el Aquinate parece dejar en claro que es imposible - no meramente inmoral sino imposibleguiar un juicio moral en una situación de elección moralmente significativa, identificando una opción como si involucrara mayor bien o menor daño que las opciones alternativas. ${ }^{24}$

Muchos usos de "mayor bien" y del "menor mal" son legítimos y no presuponen que pueda hacerse lo imposible: $\imath$ ) en el razonamiento técnico, en el que se gradúan las razones por su instrumentalidad y su utilidad relativas a una meta definida; ii) en la ordenación contemplativa de los distintos aspectos del universo, sobre la base de alguna jerarquía de dignidad o excelencia; iii) al expresar juicios morales ya efectuados, o iv) al expresar alguna clasificación que no se haya encontrado por medio de la razón, sino que haya sido "hecha" para corresponder con los propios sentimientos y emociones. ${ }^{25}$ Ninguna de las legítimas

24 El Aquinate lo rechaza en IV Sent., 6, 1, 1, ad 4; 9, 1, 5, 1 ad. 3.; S. Th., II-II, q. 110, a. 3 ad 4; III, q. 68, a. 11, ad 3; q. 80, a. 6, ad 2. Su única apelación está en un análisis de la inconstancia y la precipitación, en donde no parece haber ninguna cuestión moral a resolver.

25 Toda acción moral se hace posible por medio de sentimientos y emociones, y las preferencias y prioridades participadas por el sentimiento son muy comunes; toma muchas formas legales, políticas y culturales y a menudo son "razonables", en el sentido que no están en contra de ninguna razón: ellas no implican ninguna elección de destruir o dañar un bien humano básico, ni una parcialidad irrazonable entre las personas, y no expresan un deseo opuesto a la apertura a la realización integral humana - el bien de todas las personas y comunidades - sino meramente un deseo emocional: aversión, hostilidad o 
jerarquizaciones del hablar común dan a "mayor bien" o a "mal menor" el sentido exigido por aquellos que, desde la Ilustración, han buscado asumir el rol de la divina providencia, tratando de guiar el juicio moral por medio de estimaciones racionales de todos los bienes y males premorales involucrados en las opciones y en sus consecuencias.

Un absoluto moral sustantivo (no meramente formal) es una norma en la que un acto humano está descrito en términos que, aunque no sean morales, nos capacitan para afirmar que ningún acto de esa descripción precisa puede ser elegido sin preferir una emoción a la razón, es decir, sin seguir ciertas preferencias emocionales a expensas del tipo de razón constituido por una determinación de un bien humano básico, por ejemplo: la vida humana (en el caso de asesinato directo), la verdad en la comunicación (como en el caso de la mentira, propiamente definida), la armonía interpersonal (como en el caso de la esclavitud, comprendida más precisamente de lo que Aristóteles o el Aquinate lo hicieron; o de la manipulación de seres humanos), o el complejo de los bienes básicos de la vida y la armonía interpersonal e intrapersonal involucrados en la relación conyugal, sexualmente expresada, de amistad procreadora (como en el caso del adulterio).

Las normas morales absolutas de esta especie son solamente un fragmento de la moralidad. Son solamente la manifestación de los principios básicos de la moral: se debería elegir siempre y también desear aquellas y solamente aquellas posibilidades cuyo deseo es compatible con la realización humana integral: el bien de todas las personas y comunidades, considerado no como la meta definitiva de un plan para unos millones de años, sino como un ideal modélico y crítico. Este principio no es otra cosa que una expresión de la captación práctica inteligente de la directivi-

inercia. No obstante, al ser preferencias basadas en el sentimiento, no revelan una preferencia racional, con la que podría dar una razón para elegir, lo que es una razón para no elegir: una razón no basada en el sentimiento, sino constituida por (la inmediatez del propio deseo de) alguna concreción de un bien humano básico. 
dad integral de los bienes humanos básicos, como razones finalizadamente abiertas para la acción - como han de serlo todas las razones para la acción-.

La vida, la verdad y la armonía interpersonal como tales son todos bienes humanos básicos que brindan razones para fomentar y respetar a la comunidad, no solamente al nivel de relaciones conyugales o de vecindad inmediata, sino al nivel de la política, del Estado. La emoción más común y más fácilmente encubierta es aquella que incita a absolutizar la propia política concreta, al hacer de su propio destino, más que la realización integral humana como tal, el horizonte de la propia deliberación y elección. Tal vez sólo el horizonte de la fe cristiana y de la escatología, no asequible a Aristóteles, hace posible sobrepasar esa absolutización de horizontes emocionalmente determinados.

Una emoción de este tipo es la que fundamenta la política implícitamente defendida por Strauss y, virtualmente, por todo filósofo político de nuestra generación: la que busca asegurar el futuro de nuestra comunidad (con todos sus indudables y verdaderos bienes, incluyendo su justicia), conformando y haciendo pública la intención, condicional pero real, de imponer directamente sobre los inocentes de un Estado agresor, e indirectamente sobre los inocentes de varios o de todos los demás Estados, la destrucción del cuerpo y la muerte, conjuntamente con la ruina de todo bien humano que ellos valoren como su propio bien.

Todos los argumentos acerca de que esta política es una exigencia racional del "bien común" son demostradamente falaces, como sostenemos en los capítulos 7 y 9 de Nuclear Deterrence. Igualmente falaces, como sostenemos en los capítulos 8 y 9, son los argumentos de que la política involucra "el mayor mal" (premoral). La falla inevitable de todos estos argumentos consecuencialistas abre el camino a un método más adecuado para guiar una elección moralmente significativa. También abre el camino a una concepción de la política en la que el asegurar y respetar el bien común no incluye ni la injusticia de estar preparado a llevar a cabo, "si fuera necesario", grandes masacres de inocentes como 
represalia, ni el absurdo de estar dispuesto y de desear llevar a cabo tales represalias, "si fuera necesario", después de la entera destrucción de nuestra propia comunidad, con su demasiado estrechamente concebido y demasiado técnicamente perseguido "bien común". 


\section{TEORÍA DE LA LEY NATURAL*}

Este trabajo considera la teoría de la ley natural sólo en cuanto teoría del derecho. Esto no quiere decir que la teoría jurídica pueda ser adecuadamente identificada y elaborada independientemente de la teoría moral o política. Tampoco significa negar que existan teorías valiosas de la ley natural concentradas mucho más en los problemas fundamentales de la ética y la teoría política que con el derecho o con la teoría del derecho. Un modelo de estas teorías más amplias y fundacionales es el libro Aquinas’ Moral, Political, and Legal Philosophy (Finnis, 2005/2011). En el presente trabajo, la expresión "teoría del derecho natural" va a ser usada en lugar (shorthand) de "teoría de la ley natural", en la medida en que se refiere al derecho y es una teoría del o acerca del derecho. Esta focalización tiene el importante efecto incidental de que muchas de las diferencias históricamente importantes entre los teóricos de la ley natural pueden ser omitidas, diferencias que pertenecen más a los fundamentos de la normatividad que a la naturaleza y funciones (o "el concepto") del derecho positivo.

Los teóricos del derecho que presentan o entienden sus teorías como "positivistas", o como concreciones del "positivismo jurídico", toman a sus teorías como opuestas a, o por lo menos como claramente distintas de, la teoría de la ley natural. Por otra parte, los teóricos de la ley natural no conciben sus teorías simplemente como opuestas a, o como distintas de, el positivismo jurídico (en contra, Soper, 1992: 2395). La expresión “derecho

* El presente trabajo se publicó originalmente con el título de "Natural Law Theories", en The Stanford Encyclopedia of Philosofy, Fall 2011 Edition, Zalta, Edward N. (ed.), http://plato.stanford.edu/entries/natural-law-theories. Traducción de Carlos I. Massini-Correas. 
positivo" o "ley positiva" fue puesta en amplia circulación filosófica por Tomás de Aquino, y las teorías de la ley natural que lo siguen comparten, o al menos no hacen esfuerzo en negar, varias o virtualmente todas las tesis "positivistas" - excepto por supuesto la simple tesis de que las teorías de la ley natural están equivocadas - Las teorías de la ley natural aceptan que el derecho puede ser considerado o expuesto tanto como un puro hecho social de poder y práctica, como un conjunto de razones para la acción, que pueden ser y frecuentemente son sólidas en cuanto razones y por lo tanto normativas para la gente razonable a la que se aplican. Este carácter dual del derecho positivo está presupuesto en el eslogan bien conocido "el derecho injusto no es derecho". Entendido correctamente, este eslogan indica por qué - salvo que se base sobre la negación escéptica de la existencia de algunas razones sólidas para la acción (una negación que puede ser dejada de lado, ya que su defensa es auto-refutatoria) - la oposición positivista a las teorías del derecho natural es un sinsentido, ya que es redundante: aquello que los positivistas ven característicamente como realidades que deben ser afirmadas son también afirmadas por la teoría del derecho natural, y lo que ellos ven característicamente como ilusiones que deben ser disipadas, no es parte de la teoría del derecho natural. Pero en razón de que las teorías concebidas por sus autores como positivistas son, en general, dominantes en el ambiente de aquellos que probablemente leerán este trabajo, parece conveniente referirse a esas teorías a lo largo de este artículo con la esperanza de superar algunos malos entendidos que (así como estimulan ciertas clarificaciones y mejoras en la teorización del derecho natural) han generado algunos debates innecesarios.

La indicación realizada en el parágrafo precedente ha sido realizada de otro modo por Cristóbal Orrego (2007). Cuando las explicaciones de la aplicación y del razonamiento judicial propuestas por la corriente central de las teorías jurídicas se agregan a las explicaciones acerca del (concepto de) derecho realizadas por esas teorías, resulta claro que, en el nivel de las proposiciones 
(como distinto del correspondiente a los nombres, palabras y formulaciones), esas teorías comparten (aunque no siempre sin auto-contradicción) las principales tesis acerca del derecho que proponen los teóricos del derecho natural, como Tomás de Aquino: (i) que la ley establece razones para la acción, (ii) que las normas pueden y presuntivamente (defeasibily) crean obligaciones morales que, en cuanto tales, no existían previamente al establecimiento de esas normas, (iii) que ese tipo de obligación jurídico-moral resulta vencido o derrotado por la grave inmoralidad (injusticia) de la norma positiva, y (iv) que la deliberación, razonamiento y decisión judicial, así como cualquier otra paradigmáticamente jurídica, incluye, concurrentemente, tanto al derecho natural (moral), como al derecho (puramente) positivo. La indicación de Orrego parece resultar confirmada, e. g., el artículo sobre el positivismo jurídico de la Stanford Encyclopedia of Philosophy (Green, 2003). Pareciera, por lo tanto, que las teorías "positivistas" contemporáneas son teorías del derecho natural que se distinguen del cuerpo principal de la teoría del derecho natural: (a) por su negativa de que la teoría del derecho (en cuanto distinta de la teoría o teorías de la aplicación, del deber judicial, de la obligación jurídica de los ciudadanos, etcétera) necesaria o apropiadamente comprenda los temas relacionados recientemente enumerados y, de acuerdo a esto, (b) por el carácter incompleto de sus teorías del derecho, es decir, por la ausencia en éstas (y usualmente, aunque no siempre, en sus explicaciones de los asuntos relacionados) de una sistemática atención crítica a los fundamentos de los reclamos normativos, morales o de otro tipo, que sus teorías realizan o presuponen.

En síntesis: una teoría del derecho natural acerca de (la naturaleza del) derecho procura tanto dar una explicación de la facticidad del derecho como responder a las cuestiones que resultan centrales para la comprensión del derecho. Tal como han sido enumeradas por Green (2003) (después de haber observado que "ninguna filosofía jurídica puede ser sólo positivista"), estas cuestiones ulteriores (que "el positivismo jurídico no aspira a 
responder”) son: ¿qué tipo de realidades pueden plausiblemente contarse como méritos del derecho?, ¿qué papel han de jugar en la aplicación del derecho?, ¿qué reclamo tiene el derecho a nuestra obediencia?, ¿qué leyes hemos de tener?, y ¿hemos de tener derecho en definitiva? Todas estas cuestiones, aunque organizadas y articuladas de modo un poco diferente, serán tratadas en el presente trabajo.

\section{POSIBILITANDO LA POSITIVIDAD: LOS HECHOS SOCIALES GENERAN RAZONES PARA LA ACGIÓN}

El punto de apoyo y cuestión central de las teorías del derecho natural es la siguiente: ¿cómo y por qué puede el derecho, y su positivación en la legislación, las decisiones judiciales y las costumbres, proporcionar a sus sujetos razones fuertes para actuar de acuerdo con él? ¿Cómo puede la validez jurídica ("formal”, "sistémica”) de una norma, juicio o institución, o su facticidad o eficacia como fenómeno social (e.g., de una práctica oficial), hacerlas autoritativas en las deliberaciones de sus sujetos?

El sentido y fuerza de estas preguntas, y los caracteres principales de los tipos de respuestas dados por las teorías del derecho natural, ameritan una indicación preliminar. Por un lado, las teorías de la ley natural sostienen que el carácter "basado en fuentes" del derecho - su dependencia de hechos sociales, tales como la legislación, la costumbre o los precedentes establecidos judicialmente - es un elemento fundamental y primario en "la capacidad del derecho de promover el bien común, asegurar los derechos humanos, o gobernar con integridad" (cfr. Green, 2003). Por otro lado (otra vez cfr. Green, 2003), la cuestión de "si el derecho es por su propia naturaleza moralmente problemático" ha sido desde el principio objeto de consideración por los líderes de la tradición iusnaturalista (la primer cuestión que presenta Tomás de Aquino acerca de la ley humana en el núcleo de su discusión sobre el derecho, Summa Theologiae, I-II, q. 95, a. 1, es si la ley humana [derecho positivo] es beneficiosa - ¿no se 
harían las cosas mejor con exhortaciones y advertencias, o con jueces designados simplemente para "hacer justicia", o con líderes sabios gobernando como lo considerasen mejor - [véase abajo I.3]). Los textos clásicos y los principales entre los contemporáneos de la teoría del derecho natural tratan al derecho como moralmente problemático, entendiéndolo como un instrumento indispensable para un gran bien, pero que rápidamente deviene un instrumento de un gran mal, salvo que sus autores, de modo vigilante y firme, lo realicen bien, reconociendo y cumpliendo sus deberes morales de hacerlo, tanto fijando el contenido de sus normas y principios como en los procedimientos e instituciones mediante las cuales lo producen y administran. Todas las teorías del derecho natural entienden al derecho como un remedio contra los grandes males de, por un lado, la anarquía, y, por el otro, la tiranía. Una de las formas características de la tiranía es la cooptación del derecho como una máscara para decisiones fundamentalmente ilegítimas, ocultas bajo las formas del derecho y la legalidad.

\section{Razones básicas para la acción y la necesidad de la autoridad gubernamental}

Si se piensa cuidadosa y perceptivamente acerca de qué cosas perseguir (o evitar) y hacer (o abstenerse), se puede rápidamente entender y asentir a afirmaciones prácticas, tales como que la vida y la salud, el conocimiento y la armonía con los demás, son deseables para nosotros y cualquier otro. La deseabilidad intrínseca de estados de cosas como la propia realización (flourishing) en vida y salud, en el conocimiento y en las relaciones amistosas con los demás, se articula a través de principios del razonamiento práctico fundacionales y no-derivados (razonando hacia la elección y la acción). Estos principios del razonamiento práctico conducen hacia acciones, disposiciones y acuerdos que promueven esos bienes inteligibles, y ese carácter directivo o normativo se expresa a través de expresiones como "yo he de..." o 
"yo debo...", en sentidos que, no obstante realmente normativos, son sólo incipientemente morales.

Una teoría moral de la ley natural dará una explicación acerca del modo en el cual los primeros principios de la razón práctica toman su fuerza moral al ser considerados no individualmente, sino en su normatividad integral y única. Este carácter directivo integral se torna específico (aunque todavía en gran medida general) en principios tales como el mandamiento de amar a los demás como a nosotros mismos; o en la regla de oro de hacer a los demás lo que quisiéramos que nos hicieran a nosotros, o de no hacer a los otros lo que no quisiéramos que nos hicieran a nosotros; o en los "imperativos categóricos" de respetar, y tratar como intrínsecamente valiosos a la humanidad (los aspectos básicos de la realización humana) en uno mismo y en los otros, de modo tal que cada una de nuestras comunidades sea tratada como un reino de fines - de personas consideradas cada una como un fin en sí mismo-.

A estos principios, de alto nivel pero no sin contenido, puede dárseles mayor especificidad en dos formas: (1) identificando aquello que, dados ciertos caracteres estables de la realidad humana, ellos implican (véase I.2-4), y (2) a través de una selección - racional, pero no estrictamente deductiva - entre especificaciones alternativas, una selección denominada por el Aquinate determinatio (en plural, determinationes) (véase I.5). Las comunidades políticas son un tipo de instituciones cuyo estatus racional como un objetivo normalmente deseable y obligatorio para, y como el contexto de, una acción (y tolerancia) colaborativa, puede ser fácilmente visto como implicado por los principios prácticos y morales fundacionales. En estas comunidades, el modo normal de llevar a cabo las necesarias determinationes es la institución de la autoridad gubernamental, actuando en primera instancia a través de la legislación y de otras formas de generar normas, i. e., actuando como una fuente fáctico-social de derecho positivo (puesto).

La parte teorético-política de la teoría del derecho natural explica y elabora los fundamentos y formas adecuadas de la au- 
toridad gubernamental. Explica las diferencias y similitudes entre la autoridad práctica de los gobernantes (incluidos los electores democráticos actuando como selectores de representantes o como decidores plebiscitarios) y la autoridad teorética de los expertos y personas de juicio sensato. Explica las bases para instituir y aceptar la autoridad práctica como un medio casi necesariamente invariable para prevenir formas de daño y descuido, las cuales, por resultar contrarias a los principios morales de mayor nivel (al menos en cuanto se refieren a relaciones entre personas), envuelven o suponen injusticia. La teoría política subsume, como una de sus ramas, a la teoría jurídica. En cuanto teoría del derecho, la teoría política explica el normal deseo de que la autoridad gubernamental en las comunidades políticas sea ejercido dentro del marco de (en el eslogan clásico) un "gobierno de la ley y no de los hombres" (I.3).

\section{¿Por qué derecho "natural"? ¿Falacia naturalista?}

¿Qué intenta la corriente central de la teoría del derecho natural al usar la palabra "natural" en el nombre de esa teoría? La respuesta más breve y precisa es que intenta significar "de razón", como en las expresiones "la ley de la razón” o "los requerimientos de la razón". Tomás de Aquino es particularmente claro y explícito al decir que, en este contexto, "natural" se predica de algo (como una ley o una virtud) sólo cuando y en razón de que aquello de lo que es predicada se encuentra en línea con la razón, con la razón práctica, o con los requerimientos de la razón práctica (véase Finnis, 1980: 35-6). Más todavía, él emplea, a lo largo de todas sus obras, un axioma metodológico: la naturaleza de $\mathrm{X}$ se aprehende comprendiendo las capacidades de $\mathrm{X}$, las que a su vez son comprendidas entendiendo sus ac[tua]ciones, las que en definitiva son comprendidas por el entendimiento de sus objetos. Pero los objetos de los actos electivos son los bienes intrínsecos e inteligibles (aspectos del perfeccionamiento humano) hacia los que estamos dirigidos por los primeros principios de la razón 
práctica. De este modo, la ecuación, en este contexto, entre "natural" y "racional" y sus términos vinculados, no es una mera confusión, sino que está basada en una distinción entre epistemología y ontología: en el orden del ser, lo que es bueno y razonable para nosotros es el resultante de lo que es fundacional: nuestra naturaleza dada; pero en el orden del llegar a ser conocido, el conocimiento de nuestra naturaleza es, en una parte significativa, el resultante de nuestra comprensión de cuáles tipos de posibles objetos de elección son buenos.

Aunque el núcleo de la corriente central de la teoría clásica de la ley natural no resulta contaminada por ninguna "falacia naturalista" (Finnis, 2005, 2.4.2), el conocimiento no-práctico de los hechos cuenta, en esa teoría, de varios modos. El conocimiento de la posibilidad fáctica de (digamos) adquirir conocimiento, o de perder o salvar la vida, es un dato (no necesariamente una premisa) para la comprensión de que esas posibilidades son asimismo oportunidades - que actualizando la posibilidad podrían ser bienes para uno mismo y para otros-. Otros tipos de hechos relevantes incluyen los hechos acerca de ciertas capacidades humanas radicales y de su ausencia en ciertos animales - estos hechos son los datos para la penetración en el sentido y límites de la clase (personas, seres humanos) de los "otros", en la frase "bueno para uno mismo y para otros"- - O también, hechos acerca de la provisión limitada de recursos y de la limitada fuerza de la voluntad humana (la necesidad de incentivos, etcétera) que hacen a la apropiación de recursos por propietarios particulares (I.5) un requerimiento normal de la justicia, tanto para los no-propietarios como para los propietarios.

\section{La autoridad politica como remedio para la anarquía, la injusticia y la pobreza}

Los textos primeros (e.g., el platónico o pseudo-platónico $M i$ nos: Lewis, 2006) y más fundacionales (e. g., Gorgias, La República 
y Las leyes, de Platón, y La política de Aristóteles) de la tradición de la teoría de la ley natural recuerdan a sus lectores los males evidentes de la anarquía: un estado de cosas en el cual ninguna persona o conjunto de personas reclama eficazmente o es aceptado ampliamente como teniendo autoridad para restringir el uso de la violencia, el robo y el fraude, y en el que cualquier norma convencional de conducta se transforma en vacía, en razón de las disputas irresolubles acerca de su contenido y/o su aplicación. En una situación como esa, el más fuerte, artero y rudo se aprovecha de los más débiles; la educación de los niños (que necesita de recursos fuera de la familia) es difícil de realizar, y la actividad económica resulta atrofiada por la inseguridad de las propiedades y la falta de confianza de los emprendimientos. Aquí es evidente la necesidad de personas que articulen y refuercen estándares de conducta que tiendan a promover el bien común de la seguridad corporal, el acceso estable a los recursos, la cooperación en las actividades económicas y educacionales, y la rectificación (a través de la punición, la compensación o la restitución) de al menos las más graves injurias interpersonales, sean de comisión o de descuido. Para articular esa necesidad, hay que exponer las razones para instituir y mantener la autoridad política, especialmente el gobierno y la legislación estatal, con la condición de que esas instituciones lleven adelante sus actividades legislativas, ejecutivas y judiciales, sustancialmente para el bien común de los habitantes del territorio relevante, más que para los intereses de un segmento de la población injustamente indiferente u hostil a los intereses y el bienestar de los otros segmentos.

\section{El gobierno de la ley como remedio para los peligros de tener normas}

Aristóteles (Política, III.15.1286 a - IV 41292 a) debate vigorosamente la cuestión de si la autoridad política es mejor ejercida a través del "gobierno [primacía, supremacía] de la ley" o el 
"gobierno de los hombres", sea el de la mejor persona, o de una asamblea democrática, o por supuesto el de una corte de justicia (Retórica, I, 1, 1354 a 32 - b 16). Él ordena sus argumentos para sugerir la respuesta de que en casi todas las sociedades, en casi todas las ocasiones y asuntos, es preferible que el gobierno sea ejercido por o de acuerdo con las leyes, ya que: (i) las leyes son producto de la(s) razón(es) y no de las pasiones, (ii) la soberanía de un gobernante o asamblea tiende a la tiranía (i. e., gobierno en interés de un grupo, no del bien común), (iii) la igualdad demanda que cada persona madura tenga alguna participación en el gobierno, y (iv) la rotación de los cargos y de los que los ejercen es deseable y difícilmente puede ser manejado sin regulación legal. Por lo tanto, para Aristóteles, el caso central de autoridad práctica es el gobierno de una polis por la ley y por gobernantes reglados legalmente.

La explicación de Tomás de Aquino de la ley humana positiva trata el caso central del gobierno como el auto-gobierno de un pueblo libre, por los gobernantes e instituciones que ese pueblo ha designado para ese propósito, y el caso central del derecho es el de la coordinación por la ley de sujetos voluntarios, ley que, por su carácter público (promulgación), claridad, generalidad, estabilidad y carácter práctico, trata a esos sujetos como participantes en la razón pública (Summa Theologiae, I-II, q. 90, a. 4 c; q. 95, a. 3 c; q. 96, a. 1; q. 97, a. 2). Porque define las leyes como proposiciones prácticas universales (en el sentido lógico de "universales") concebidas en la razón del gobernante, y comunicadas a la razón del gobernado de tal modo que éste pueda tratar esas proposiciones, al menos presuntivamente, como razones para la acción - razones tan decisivas para cada uno de ellos como si hubieran sido concebidas por cada cual y adoptadas por ellos mismos a través de un juicio y elección personal-.

Lon Fuller (1969) reconociendo el liderazgo del Aquinate en esta discusión de los aspectos formales y procedurales del sistema jurídico, reúne las dispersas y fragmentarias puntualizaciones realizadas en este tópico, en una lista ordenada de ocho elemen- 
tos del gobierno de la ley (rule of law), es decir, de la primauté du droit, del sistema jurídico, del Rechtsstaat. Fuller muestra que esos ocho elementos concuerdan como un conjunto de desiderata (o requerimientos) porque son implicaciones o especificaciones de la aspiración y el deber de tratar a la gente como presuntivamente dotadas de un título - como materia de imparcialidad y de justicia - a ser gobernadas como personas libres, fundamentalmente iguales a sus gobernantes, no como títeres o peones de ajedrez que pueden ser manejados y ordenados a través de la manipulación, la incertidumbre, el miedo, etcétera. El resultado normal de esa imparcialidad en los procedimientos para elaborar y mantener el derecho será también el de fortalecer la eficacia del derecho.

Lamentablemente, la superficie del texto de Fuller da más prominencia a la efectividad que a la imparcialidad, y varios críticos (e. g., Hart, Dworkin) pasan por alto las connotaciones morales de las alusiones de Fuller a la reciprocidad entre gobernantes y gobernados, considerando al título de su libro, The Morality of Law, una denominación impropia. Esta tesis ha sido elaborada más cuidadosamente sobre diferentes bases por Raz (1979) y Kramer (2004a y 2004b): a pesar de que el gobierno de la ley (y su cumplimiento) puede ser moralmente importante y aun una virtud moral (en cuanto normalmente necesaria para un completo gobierno justo en una sociedad justa, y especialmente para disminuir los peligros que se siguen de la existencia de la autoridad política, así como de la ley misma), resulta no obstante moralmente neutral, desde que (en Estados que emplean las formas del derecho) ese modo de gobierno sería normalmente necesario aun para gobernantes profundamente injustos para realizar sus propósitos inmorales. Sería como un cuchillo filoso, cuyo filo lo hace apto para una cirugía que puede salvar una vida, pero también para la acción de asesinos furtivos y crueles (Raz, 1979: 224-6).

Finnis (1980/2011) y Simmonds (2004, 2005, 2006, 2007) han desafiado el reclamo cuasi-empírico de que aun los tiranos viciosos necesitan o encuentran apto, para la eficacia de su do- 
minación, cumplir con los requerimientos del gobierno de la ley. El octavo de los requerimientos propuestos por Fuller para el gobierno de la ley, es decir, la adhesión de los gobernantes, en su conducta en cuanto tales, a sus propias normas, es especialmente obstructiva, más que promotora, de los propósitos del tirano. Pero el foco del interés de Fuller y el más fructífero ámbito de debate no se encuentra tanto en los fenómenos históricos o sociológicos, sino en las razones prácticas "internas" que están en juego. Si los gobernantes no respetan en algún aspecto los derechos e intereses de algunos de sus sujetos, en relación con cuestiones sustantivas (vida, seguridad corporal, libertad, propiedad, y así sucesivamente), ¿por qué tendrán los gobernantes que respetar esos derechos - qué razón tienen para hacerlo - en las cuestiones de procedimiento involucradas en el gobierno de la ley (dándoles información imparcial acerca de lo que se espera de ellos y adhiriendo como gobernantes al derecho promulgado cuando valoran su conducta, así como en otros tratos gubernamentales con esos sujetos)? Una más o menos inconsistente voluntad de los gobernantes de atar sus manos por una adherencia escrupulosa a la justicia procedimental, mientras son sustantivamente injustos, es por supuesto psicológicamente posible. Pero la preocupación primaria de Fuller, así como la de la amplia tradición de la teoría de la ley natural, es con una racionalidad y unas implicancias específicas de la razonabilidad que sean completas y coherentes: es decir, con el juicio y la elección moralmente razonables.

\section{Ius Gentium - ius cogens - mala in se - derechos humanos: normas jurídicas y derechos establecidos en cuanto elementos moralmente necesarios de cualquier sistema jurídico}

Fuller ofrece una teoría de la ley natural meramente procedimental, aunque no niega que una teoría de la ley natural sustantiva sea posible y apropiada. Y por supuesto no hay razón suficiente para seguirlo en su restricción del alcance de la reflexión 
teórico-práctica acerca de lo que es necesario para una sociedad política que valora las auto-restricciones y la aceptación de las responsabilidades que el derecho requiere a aquellos a quienes se aplica. Porque resulta claro que los procedimientos e instituciones del derecho están al servicio de propósitos sustantivos: la restricción de la violencia, el robo y el fraude, la devolución de las cosas desapropiadas a sus propietarios legítimos o poseedores y de las pérdidas incorrectamente impuestas, la protección de los bienes intangibles, como la reputación contra la difamación injustificada, así como de los inmaduros, los mentalmente inhábiles y otras personas vulnerables, contra la explotación sexual o de otro tipo, y así sucesivamente. Aquella porción de nuestro derecho positivo que consiste en principios jurídicos o normas que efectivizan propósitos como los recientemente enumerados son habitualmente denominados, por las teorías del derecho natural, ius [o jus] gentium.

Acuñada por los juristas del derecho romano clásico, como Gayo (c. 165 AD), esta expresión - literalmente "la ley de los pueblos" - alude al conjunto de normas y principios que se encuentran de modo similar, aunque no idéntico, en virtualmente todos los sistemas jurídicos. La razón de su ubicuidad es, generalmente hablando, que cualquier consideración razonable de aquello indispensable para que los individuos, las familias y otras asociaciones puedan vivir juntos tolerablemente bien en la sociedad política, identificará estos principios y normas como necesarias. En el derecho moderno, éstas son designadas, en principio, por nombres tales como "los principios generales del derecho reconocidos por las naciones civilizadas" (Estatuto de la Corte Internacional de Justicia, artículo 38), ius cogens erga homnes (literalmente "derecho que es vinculante [sin acuerdo o promulgación u otras formas de adopción] en relación con todos", "derecho superior", o "derechos humanos fundamentales".

En la teoría del derecho de Tomás de Aquino, ellas son designadas como conclusiones (implicaciones) de los principios de nivel más elevado, de los principios morales más generales. En la tra- 
dición del derecho natural, las incorrecciones recogidas por esos principios son denominadas mala in se, como distintas de los mala prohibita - cosas que son incorrectas en sí mismas, como distintas de aquellas que son incorrectas sólo porque están prohibidas por el derecho (positivo) - y esta distinción permanece en uso, por buenas razones, en el razonamiento judicial.

Algunas teorías jurídicas hablan de estos principios y reglas como pertenecientes al derecho en razón de una necesidad de tipo conceptual. Hart (1961) puede ser leído de este modo. Pero aun la explicación de Hart, examinada más de cerca, identifica la necesidad relevante no como conceptual o lingüística, sino como una concreción de la necesidad racional de medios indispensables para asegurar objetivos que no son opcionales. Es por esta razón que Hart se refiere a ellos como constituyendo "los contenidos mínimos del derecho natural”. Podría haber expresado más perspicuamente este significado si hubiera hablado del “contenido mínimo del derecho positivo, el conjunto mínimo de principios que, en razón de resultar racionalmente necesarios - dados ciertos «truismos» fundamentales sobre la naturaleza humana y las necesidades humanas - para asegurar propósitos compartidos por todas las sociedades humanas capaces de sobrevivir, pueden ser llamados derecho natural". El hecho es que estos elementos de nuestro derecho son tanto positivos (realizados por y formando parte de la práctica oficial) como naturales (requeridos racionalmente al menos por el mínimo de realización humana). Estas cuestiones son discutidas más extensamente más abajo en la sección III.

5. "Derecho puramente positivo": las determinationes y su autoridad jurídico-moral para ciudadanos y jueces (los hechos generan razones para la acción)

La teoría jurídica del derecho natural tiene su característica más distintiva en su explicación del derecho puramente positivo, 
el cual, aunque enteramente dependiente para su estatus jurídico del hecho de haber sido puesto por ciertas personas o instituciones, no obstante participa de la característica del derecho de conllevar, al menos presuntivamente y de modo derrotable (defeasibly), ** una obligación moral de cumplimiento. Acerca de estas normas de un sistema jurídico positivo, Tomás de Aquino dice que a pesar de que ellas han de ser, y se presume que son, "derivadas del derecho natural", tienen su fuerza jurídica sólo por ser parte de un determinado sistema positivo (ex sola lege humana vigorem habent: ST, q. 95, a. 3).

$\mathrm{Su}$ explicación, ligeramente actualizada, sería la siguiente: esta gran parte (positiva) de nuestro derecho podría razonablemente haber sido diferente, en el sentido en que cada detalle de un hospital maternal podría haber sido de algún modo diferente, y gran parte de su diseño podría haber sido muy diverso, aunque ciertos caracteres (e.g., que las puertas y los techos tengan más de un metro de altura) están supuestos en la comisión de construir un hospital maternal, y cada característica de la obra tiene alguna conexión racional con la comisión. Este tipo de conexión racional que se mantiene aun cuando el arquitecto tiene una amplia libertad de elección entre alternativas infinitamente diferentes, es llamado por Tomás de Aquino una determinatio de los principios - un tipo de concretización de lo general, una particularización que une la necesidad racional del principio con la libertad (del legislador) de elegir entre concretizaciones alternativas, una libertad que incluye elementos de (en el buen sentido) arbitrariedad-.

Una vez que la determinatio es realizada válidamente, cumpliendo los criterios de validez provistos por el derecho constitu-

** Cabe consignar que las palabras "derrotable", "derrotablemente" y "derrotabilidad" no figuran en el Diccionario de la Real Academia Española (consulta informática del 26 de enero de 2013), y por lo tanto no podrían, al menos en principio, ser utilizadas en la lengua española. No obstante, como han sido aceptadas ampliamente en la literatura científico-jurídica, se emplearán varias veces en la presente traducción. 
cional del sistema jurídico relevante, ésta modifica el estado preexistente del derecho, introduciendo una norma o proposición de derecho nueva o corregida. La norma de derecho nueva o enmendada proporciona a los jueces, otros oficiales y a los ciudadanos, nuevas o enmendadas razones para la acción (o para la abstención). El hecho de que la norma nueva o corregida dependa de una fuente social-fáctica, constituida o empleada por el acto de determinatio, no implica que una razón normativa (un "deber") sea ilógicamente derivada de un mero hecho (un "es"). Más bien, la norma nueva o enmendada es normativa, directiva y (cuando ese es su sentido normativo) obligatoria, porque ese hecho social puede ser la segunda premisa en un silogismo práctico cuya primera premisa es normativa: "debe haber un hospital maternal en esta ciudad", "la gente debe ser protegida contra los atentados homicidas", "la gente debe ser requerida para contribuir a los gastos públicos de las funciones gubernamentales apropiadas", "las víctimas de asalto, robo, ruptura de contratos, negligencia, etcétera, deben ser compensadas", "el tráfico vial debe ser regulado para reducir los daños por colisiones", y así sucesivamente. La normatividad moral del principio resulta replicada en las normas más específicas creadas por la determinatio, aun cuando la última no sea una inferencia directa de la primera.

Esto quiere decir que la norma concretizada es (tanto moral como jurídicamente) normativa, en razón de que esa normatividad está (presuntivamente y prima facie) implicada por el principio (moral) de que el bien común (cuyo contenido fundamental es dado por los principios fundacionales de la razón práctica: I.1) requiere que las instituciones autoritativas actúen para especificar, aplicar y reforzar algunas normas en las materias relevantes. Los hechos sociales transforman a una norma positiva en razón para la acción porque la deseabilidad de la autoridad como medio para asegurar el bien común, y la deseabilidad del "gobierno de las leyes y no de los hombres", son razones potentes y permanentes para el reconocimiento de esos hechos como instancias de legislación válida que dan presuntivamente razón suficiente para 
su cumplimiento. El derecho puramente positivo que es jurídicamente válido es (presumible y derrotablemente) también moralmente válido y vinculante - tiene la forma moral o el significado de la obligatoriedad jurídica - cuando y en razón de que ocupa su lugar en un esquema de razonamiento práctico cuyo más próximo punto de partida es la necesidad moral de justicia y paz, y cuyo punto de partida más fundamental es la gama de formas básicas en las que el bienestar humano puede ser promovido y protegido, del modo recogido en los primeros principios de la razón práctica.

Por lo tanto, en relación con el derecho positivo establecido, la teoría del derecho natural - tal como es reconocido por un buen número de positivistas jurídicos, e. g., Raz, 1980: 213; Gardner, 2001: 227- comparte la principal tesis de los positivistas jurídicos contemporáneos: que el derecho depende para su existencia y validez de hechos sociales.

\section{Obligatoriedad "presuntiva" y prima facie}

La obligación u obligatoriedad jurídico-moral de una norma jurídica es la contraparte de la autoridad o autoritatividad de su autor (el que la promulga) o de otra fuente. La idea de autoridad ha sido clarificada por teóricos jurídicos contemporáneos, como Raz y Hart, a través de la reflexión sobre los tipos de razones para la acción intencionalmente propuestas a los sujetos potencialmente actuantes por un ejercicio de la autoridad práctica. Los tipos relevantes de razón práctica han sido llamados indistintamente exclusionarios, perentorios o pre-emptivas, e independientes de su contenido. La idea central es que los sujetos son instruidos para tratar la razón proferida (es decir, la previsión normativa, o la orden judicial), en sus deliberaciones para la elección o la acción, como una razón que no simplemente se agrega a las otras razones que él ya tiene para actuar en un sentido y no en otro, sino que más bien las excluye y toma el lugar de algunas de esas razones. 
Y esta fuerza exclusionaria, perentoria o pre-emptiva es debida no al atractivo inherente para la razón del contenido de la razón proferida, sino al estatus de su autor —o de otra fuenteen cuanto titulada - por ejemplo, por su papel en un esquema constitucional de gobierno para la solución de los problemas de coordinación de una comunidad política - para ser obedecida, cumplidos sus mandatos, tratada como autoritativa (véase e. g., Raz, 1986: 35-69). Esta independencia de contenido de las razones autoritativas implica su obligatoriedad presuntiva. La capacidad de ser desplazada que reviste esta presunción está implicada en la dependencia de la fuerza perentoria, pre-emptiva o exclusionaria de esas razones respecto de un trasfondo presupuesto de bienes y necesidades humanas básicas, y de principios morales básicos y normas, un trasfondo que supone que si una razón autoritativamente proferida (positiva) entra en conflicto suficientemente claro con esas necesidades, bienes, principios o normas permanentes, su fuerza exclusionaria deviene exhausta o superada, y las obligaciones positivas resultan derrotadas.

Dicho de un modo menos abstracto, tanto la efectividad del derecho, como solución a los problemas de coordinación y promotor del bien común, como la imparcialidad de demandar adhesión a ese derecho, resultan dependientes de su ser tratados, tanto por los sujetos como por los administradores del sistema jurídico, como jurídica y moralmente titulados, precisamente en cuanto derecho válidamente elaborado, para prevalecer frente a todas las otras razones, salvo las razones morales competitivas de mayor fuerza. Es esta titulación la que es negada por la injusticia grave de una norma o de un sistema jurídico. Véase III y IV más abajo.

\section{LAS PERSONAS HUMANAS NO SON CREAGIONES} DEL DERECHO SINO SU RAZÓN DE SER

Hablar de aspectos del bienestar o del florecimiento humano y de los principios de la razón práctica no ha de distraer la aten- 
ción de una verdad importante, implícita tanto en el tratamiento filosófico y jurídico clásico de griegos y romanos acerca de la justicia como en la atribución jurídica moderna de los derechos humanos. Por supuesto, la Declaración Universal de Derechos Humanos (1948) vincula las dos tradiciones de discurso al colocar a la cabeza de su articulación de los derechos humanos el núcleo ("todos los seres humanos han nacido libres e iguales en dignidad y derechos") del dicho jurídico romano (Institutas, 1.2.2) acerca de que "por naturaleza, desde el comienzo, todos los seres humanos han nacido libres e iguales", un dicho acerca de la iustitia, la justicia como fundamento y estándar para el ius, el derecho. Los mismos textos del derecho romano, promulgados como derecho permanente por Justiniano en 533-535 d. C., sostienen más de una vez que el objetivo del derecho (su causa "final" o razón explicativa) son las personas humanas en razón de las cuales es elaborado, es decir, todas las personas humanas, hasta los tiempos en los que el ius gentium, la ley común de los pueblos, fue distorsionado por las guerras y la esclavitud. El derecho, establecido para asumir un lugar directivo en el razonamiento práctico hacia un juicio moral ajustado, existe en razón de las personas humanas: todos los miembros de la comunidad regulada por ese derecho y todas las otras personas incluidas en el ámbito del derecho.

Esa tesis cae juntamente con aquellas partes de la teoría jurídica que son reconocidas pero no exploradas demasiado por los positivistas jurídicos contemporáneos. Fue ignorada y hasta negada por las primeras formas del positivismo jurídico, dotadas de mayor ambición de cubrir la totalidad de la filosofía jurídica, e. g., la de Hans Kelsen. Kelsen negaba que las personas fueran reconocidas por el derecho o bien por una adecuada teoría del derecho o ciencia jurídica, excepto en la medida en que resultaran el sujeto de una norma jurídica positiva. Pero contra esa restricción, que ha desviado a algunos tribunales que han adoptado la ciencia jurídica kelseniana como guía del razonamiento judicial, es posible sostener (Finnis, 2000) que la igualdad y dignidad fundamental de los seres humanos ha de ser defendida como 
parte de un concepto o una comprensión racionalmente sólida del derecho.

Esta defensa requiere una explicación de la diferencia entre las capacidades que están activas aquí y ahora, o están más o menos listas para ser activadas, y las capacidades radicales tal como existen en los primordiales epigenéticos de los seres humanos, aun los muy jóvenes, y en la constitución genética y somática aun de los gravemente discapacitados. Aunque esa explicación hace posible la defensa de la igualdad fundamental de los seres humanos, y por lo tanto una teoría jurídica humanista, el objetivo de la explicación no es privilegiar una especie biológica en cuanto tal, sino afirmar el significado jurídico del estatus de personas - sustancias de naturaleza racional- como inherentemente titulares (sujetos) de derechos de un tipo diferente, y merecedores de mayor respeto y valor finalista que los derechos que son muchas veces, como medios técnicos, atribuidos por el derecho a los animales, a ídolos, barcos u otros objetos de los procedimientos jurídicos.

\section{PRINCIPIOS JURÍDICOS PARA REMEDIAR EL DEREGHO POSITIVO DEFECTIVO}

\section{La adjudicación entre el positivismo inclusivo y exclusivo}

La tesis positivista de que todo derecho depende para su existencia, validez y obligatoriedad de sus fuentes fáctico-sociales está muchas veces acompañada, tal como en el "positivismo jurídico excluyente" (Raz, 1980: 212-24; Raz, 1985), por la tesis de que los jueces, como "instituciones primarias de aplicación del derecho", tienen un deber (no sólo moral, sino también jurídico) de decidir cierto tipo de casos (e. g., casos en los que la norma jurídica existente produciría injusticia), mediante la aplicación de principios o normas morales que suponen el abandono o la rectificación de parte del derecho existente. Los positivistas jurídicos "incluyentes" atemperan esto sosteniendo que el deber judicial y la autorización 
de apartarse del derecho existente a través de la aplicación de principios o normas morales está restringido a aquellas clases de casos en los que una regla de derecho con una fuente jurídica socialfáctica dirige al tribunal a hacerlo; el efecto de esa directiva, sostienen, es el de incluir en el sistema jurídico las normas o principios morales indicados (si es que hay alguno).

La teoría de la ley natural coincide con Raz y Gardner en rechazar la restricción inclusivista como infundada, pero disiente de ellos al sostener (como también lo hace Dworkin, 1978: 47) que cualquier norma o principio que un tribunal está obligado o autorizado a aplicar, precisamente como tribunal, puede razonablemente ser reconocido y contar como derecho, $i$. e., como norma o principio que ha de ser considerado ya como parte de nuestro derecho. En contra de los positivistas en general, esa teoría sostiene que (i) poco o nada interesa que los principios morales que obligan a los tribunales en cuanto tales sean considerados o no parte de nuestro derecho; pero (ii) si algo importa en el nombre - si, por ejemplo, es reclamado que las cortes no pueden "tomar noticia judicial" de cualquier norma o principio que no "sea parte de nuestro derecho" (y por lo tanto, como en el caso de las normas de derecho extranjero, debe recibir pruebas de la existencia de esas normas y de su contenido) - es más sensato decir que las normas o principios judicialmente aplicables (no como en el caso de la ley extranjera aplicable) son ipso iure (i. e., precisamente en cuanto jurídica y moralmente aplicables) normas de derecho. Esas normas pertenecen a la porción de nuestro derecho correspondiente al ius gentium.

¿Equivale esto a un reconocimiento de que la teoría de la ley natural está significativamente menos interesada que las teorías positivistas contemporáneas en establecer los límites precisos y el contenido del derecho de fuentes social-fácticas (puesto, puramente positivo) de nuestra comunidad? No realmente. Porque (i) las teorías positivistas contemporáneas han abandonado la tesis de los iuspositivistas "clásicos", como Bentham, en el sentido de que tanto los jueces como los ciudadanos han de cumplir (como ob- 
jeto de una obligación político-moral) con la ley positiva de su comunidad: sus tratados o ensayos de teoría jurídica implícita o explícitamente recomiendan a los jueces y a los ciudadanos la afirmación hartiana: "Esto es derecho; pero es demasiado inicuo como para ser aplicado u obedecido" (Hart, 1961: 203; 1994: 208), mejor que la benthamita "Bajo un gobierno de leyes... obedecer puntualmente y... criticar libremente" (Bentham, 1776); de este modo, su interés en distinguir la ley positiva de otros estándares para una segura y legitimada adjudicación aparece, en último análisis (y a pesar de las apariencias), como siendo meramente provisional.

Por otra parte, (ii) las teorías de la ley natural sostienen tan fuertemente como cualquier teoría positivista que una adjudicación segura y legitimada da prioridad a una atención consciente y experta a las fuentes social-fácticas y a las reglas y principios enraizados en esas fuentes, poniendo éstas aparte sólo si son, y en la extensión en que lo sean, "demasiado injustas para ser aplicadas", y adaptan la nueva regla resultante para que resulte coherente todo lo que sea posible con las restantes (y no tan injustas) doctrinas, normas y principios del sistema jurídico particular en que el juez ejerce su jurisdicción.

\section{Un caso testigo: la cuestión Nüremberg}

Las personas reconocidas como los mayores criminales de guerra alemanes fueron juzgadas en 1945 por delitos especificados en un acuerdo (The London Agreement and Charter of 8 August 1945) suscrito entre los Estados que gobernaban Alemania después de su rendición. Los jueces sostuvieron que los acusados habían estado, en todas las ocasiones relevantes, obligados por (y en varios casos habían actuado en violación de) los principios y normas especificados en la Carta de Londres, obligaciones derivadas no - por supuesto - del acuerdo (que se había realizado después de los actos en cuestión), sino más bien, como algunos 
de los crímenes imputados, del derecho internacional, así como en el caso de los imputados por "crímenes contra la humanidad", de los "dictados elementales de la humanidad". Considerar a los acusados responsables de la violación de estas normas y dictámenes, y rechazar cualquier argumento acerca de que la adecuación de sus actos a la ley alemana podía hacerlos legítimos, no significó (y así lo estableció el tribunal) violar el principio de derecho y de justicia de que nadie puede ser castigado salvo por violación del derecho.

El resultado de estos fallos puede ser explicado por (i) el positivismo excluyente: el tribunal estaba moralmente autorizado para aplicar normas morales, a pesar de que las normas así aplicadas no eran normas de derecho, ni al tiempo de comisión de los crímenes ni al tiempo de la acusación. Pero los términos de esas sentencias pueden ser explicados por (ii) el positivismo incluyente: la Carta de Londres era derecho positivo para el tribunal y lo mandaba aplicar normas morales que, en virtud de esa directiva jurídica, eran también normas jurídicas. Todavía, (iii) la explicación de la teoría del derecho natural aparece como la más explicativa: las normas morales aplicadas eran también normas del "derecho superior", aplicable en todos los tiempos y lugares (y por lo tanto en Alemania y sus territorios, antes y después de la Carta) como fuente de argumentación y de juicio "de acuerdo con el derecho" cuando las fuentes social-fácticas, que son las normalmente dominantes y cuasi-exclusivas fuentes del derecho, eran en justicia, guías insuficientes e inadecuadas para cumplir obligaciones como la obligación judicial de hacer justicia conforme a derecho, o la obligación de todos de comportarse con una humanidad elemental, aun bajo órdenes de no hacerlo. Esto es así aun cuando esas órdenes tuvieran validez jurídica intra-sistémica, de acuerdo con los criterios formales o social-fácticos de algún sistema jurídico existente. Y si alguien tiene dudas acerca de la justicia de los vencedores, esas dudas pueden, asimismo, remitirse a los principios del mismo derecho superior, ius gentium, o derecho de la razón o de la humanidad. 


\section{El derecho natural y el derecho (puramente) positivo} como dimensiones concurrentes del razonamiento jurídico

La teoría de la ley natural se encuentra, a este respecto, próxima a la explicación de Ronald Dworkin del derecho y de la adjudicación, no sólo en situaciones fronterizas como la de Nüremberg, sino también en el trabajo cotidiano de un sistema jurídico sofisticado. La adjudicación normal y el razonamiento judicial tienen dos dimensiones o criterios para distinguir la corrección de la incorrección en los juicios. Una dimensión comprende las fuentes social-fácticas (leyes, precedentes, prácticas, etcétera), llamados por Dworkin "materiales jurídicos". La otra dimensión abarca los estándares morales, presumiblemente aquellos prevalecientes en la comunidad a la que pertenece el juez, pero en último análisis, sólo aquellos estándares que el juez puede aceptar como en verdad moralmente irrebatibles.

Una interpretación de nuestro derecho que sea moralmente la más adecuada será jurídicamente correcta aun cuando se ajuste menos a los materiales jurídicos que otras interpretaciones alternativas, supuesto que se ajuste "lo suficiente" a las fuentes social-fácticas. Los estándares morales así aplicados, que Dworkin (en la misma línea que la teoría del derecho natural) trata como susceptibles de ser moralmente objetivos y verdaderos, funcionan por lo tanto como fuentes directas de derecho y, en cierto sentido, como siendo ya derecho, excepto cuando su ajuste con el conjunto completo de las fuentes social-fácticas sea tan débil que sería más correcto (según Dworkin) decir que los jueces que los aplican están aplicando moral y no derecho (y por lo tanto, si ellos afirman que están aplicando derecho, se estarían equivocando o mintiendo - una mentira que Dworkin considera a veces encomiable-) (Dworkin, 1978: 326-7, 340).

Una teoría del derecho que, a diferencia de la de Dworkin, se coloque a sí misma directamente en la tradición de la teorización del derecho natural, probablemente se apartará de estas posiciones de dos maneras. (i) No aceptará la tesis de Dworkin de que 
aun en los casos muy difíciles existe sólo una respuesta correcta en derecho; negará su asunción de que existe una sola medida correcta y racionalmente identificable acerca de cuánto ajuste con los materiales jurídicos existentes (fuentes social-fácticas) es "suficiente" (necesario y suficiente) como para habilitar el uso de estándares morales para identificar la interpretación jurídicamente correcta del derecho. En ausencia de esa única medida, el razonamiento jurídico deberá a menudo - y en los casos muy difíciles, usualmente - contentarse con mostrar que dos o tres interpretaciones alternativas se distinguen de un número indefinido de otras interpretaciones por ser correctas, es decir, no erróneas (aunque no las únicamente correctas). (ii) Cuando los jueces, en orden a evitar una grave injusticia, se apartan de la comprensión del derecho ya establecida (y quizá de los términos claros de un decreto) y aplican una interpretación alternativa, moralmente imperada, considerándose autorizados para hacerlo por la ley superior de la razón, la naturaleza y la humanidad, no estarán mintiendo si afirman que, haciéndolo, están tanto rectificando como aplicando el derecho (de su Estado). Véase IV, más abajo.

\section{Implicaciones del gobierno de la ley necesarias para la positividad}

En la misma línea de la explicación de dos dimensiones propuesta por Dworkin (así cualificada), la teoría del derecho natural asentirá a la tesis que Green considera característica del positivismo jurídico:

[1] el hecho de que una política sea justa, sabia, eficiente o prudente, nunca es una razón suficiente para pensar que sea realmente derecho, y [2] el hecho de que [un derecho] sea injusto, insensato, ineficiente o imprudente, nunca es una razón suficiente para dudar [de que sea derecho].

Porque en referencia a [1]: lo que el gobierno del derecho y no de los hombres requiere es la institución de un sistema jurídico, 
un corpus iuris, y de este modo lo que un principio de la moralidad (derecho natural) o ius gentium implica que sería un apropiado gobierno del derecho es, sin embargo, no todavía una parte de nuestro derecho - menos aún es una mera "política" hecha derecho al ser "prudente" o "eficiente" -, salvo que su contenido, conceptualización y forma estén de tal modo informados, ya sea en el pensamiento judicial u otro saber jurídico o en los juicios o la legislación, como para cohesionar con las restantes partes (especialmente las partes más vecinas) de nuestro derecho.

Y en referencia a [2]: una teoría del derecho natural, consciente del carácter deseable del gobierno del derecho y no de los meros jueces (véase I.3), puede muy bien ser más cautelosa que el mismo Dworkin al apartarse del derecho establecido (basado en fuentes social-fácticas). En aquellas ocasiones en que este apartamiento está moralmente justificado, la teoría sugerirá que el juez está autorizado a proceder de acuerdo con el derecho superior y perenne de la humanidad, el ius gentium o conjunto de principios universales de derecho y justicia comunes a todos los pueblos civilizados, que priva al derecho establecido - más precisamente, al que ha sido aceptado en una determinada jurisdicción como derecho establecido - de su carácter directivo tanto para los sujetos como para los jueces. ¿Esta autorización moral es también "jurídica" y "conforme a derecho"? ¿El derecho establecido, que el juez está moralmente autorizado a dejar de lado, ha de ser tratado, aun antes de que el juez dicte sentencia, como no-derecho? La sección siguiente argumenta que la cuestión ha de ser respondida tanto con un "sí" como con un "no".

\section{IV. ¿"LEX INIUSTA NON EST LEX”? ¿LAS NORMAS SERIAMENTE INJUSTAS OBLIGAN? ¿OBLIGAN JURÍDICAMENTE?}

En esos casos, el derecho establecido por fuentes social-fácticas, al perder su carácter directivo para jueces y ciudadanos, ¿pierde también su validez jurídica? La respuesta depende del contexto 
discursivo en el que se plantea la cuestión. Si un curso de pensamiento y reflexión hace apropiado reconocer el carácter de "establecido" o "puesto" de las normas como cognoscible con referencia a las fuentes social-fácticas, se puede decir que son jurídicamente válidas, pero demasiado injustas como para ser obedecidas y aplicadas. Pero si, en cambio, el contexto discursivo hace apropiado puntualizar su falta de normatividad para jueces y ciudadanos, se puede decir que la norma, a despecho de sus vínculos con fuentes social-fácticas, es no sólo moralmente no-directiva, sino también jurídicamente inválida. Cada modo de hablar dice una parte importante de la verdad, o mejor aún, dice la verdad con un énfasis que difiere del que corresponde al otro.

El significado de "un derecho injusto no es derecho" es esencialmente idéntico al de la frase de Hart, "esto es derecho, pero demasiado inicuo para ser obedecido y aplicado" (o alegable como defensa). La excitación y la hostilidad surgidas entre los teóricos jurídicos modernos (especialmente Hart) por el primer modo de hablar resultan injustificadas. Nadie tiene dificultad para comprender locuciones tales como "un argumento inválido no es un argumento", "un amigo desleal no es un amigo", "una medicina de curandero no es una medicina", y así sucesivamente. Lex iniusta non est lex tiene la misma lógica: reconoce, en sus palabras iniciales, que lo que está en cuestión es, en ciertos aspectos importantes - quizá normalmente y presuntivamente decisivos - derecho, pero luego, en su retractación o negación de ese predicado, afirma que, desde que la justicia es el verdadero objetivo de tener y respetar el derecho, esta deficiencia particular del derecho respecto de la justicia lo priva del significado decisivo que todo derecho pretende tener. Se trata aquí entonces de derecho sólo en el sentido de que ha de ser juzgado - especialmente cuando el derecho es considerado, como por el mismo Hart, como un tipo de razón o pretendida razón para el obrar - como un sentido no-central, distorsionado o secundario de derecho. 
Nota: La teoría política clásica, tal como fue expuesta por Platón, Aristóteles y Tomás de Aquino, hace un uso regular de esta distinción entre instancias centrales e instancias pervertidas o de algún modo marginales de un mismo concepto o término analógico, y de este modo el Aquinate nunca dice pura y simplemente "el derecho injusto no es derecho", sino más bien "el derecho injusto no es pura y simplemente [simpliciter] derecho" o afirmaciones similares. Además, él dice en varios lugares que "un juicio injusto [de un tribunal] no es un juicio" y parece claro que puede haber utilizado la locución simplificada, en forma de eslogan, como abreviatura.

Todo esto parece haber sido pasado por alto por Hart en su polémica (Hart, 1961: 204-7; 1994: 208-12) en contra del adagio lex iniusta non est lex. El argumento de Hart de que el uso del eslogan podría tender a desalentar o confundir la crítica moral del derecho, aparece como histórica y lógicamente indefendible. El eslogan es ininteligible salvo como una expresión y una incitación a comprometerse en ese tipo de crítica, y no puede ser rechazado sin antes haberlo citado equivocadamente, tal como lo hacen invariablemente Hart y todos aquellos que utilizan su argumento, apartando la atención del primer predicado del eslogan y de su aserción implícita: que la norma injusta en cuestión es una regla de derecho.

Algunas teorías han adoptado ciertas afirmaciones de la teoría del derecho natural, y afirman ser teorías del derecho natural, pero han sostenido que aun las normas más injustas crean una obligación de obedecer, obligación que es a la vez jurídica y moral. La de Kant (véase Alexy, 2002: 117-121) es una de esas teorías: un sistema jurídico puede estar integrado enteramente de derecho positivo, pero debe ser "precedido por un derecho natural que establezca la autoridad del legislador... a obligar a los demás simplemente por su acción arbitraria”. Pero esta pretendida norma básica de derecho natural mira no a la justicia de los contenidos de las normas jurídicas positivas, sino exclusivamente a la necesidad de certeza jurídica y de paz cívica, que Kant adop- 
ta para excluir todo derecho de resistencia a las leyes injustas, así como cualquier negativa de que son plenamente jurídicas. Alexy ha puesto de relieve las confusiones e inconsistencias de las tentativas de Kant de evadir la posición clásica acerca de que las normas cuya injusticia es lo suficientemente grave, pueden y deben considerarse desprovistas del carácter jurídico predicable de las normas de derecho, y que los ciudadanos y los tribunales, en tanto que tribunales, están jurídica y moralmente titulados para considerarlas como - o tratar como si fueran - no-derecho. En éste, como en varios otros aspectos, los desarrollos filosóficos de los siglos dieciocho y diecinueve (así como sus homólogos de los siglos veinte y veintiuno) han sido no tanto progresos como retrocesos.

\section{V. ¿PUEDen las teorías generales \\ DEL DERECHO SER LIBRES DE VALORACIONES? ¿DE VALORACIONES MORALES?}

Las descripciones de las valoraciones realizadas por personas particulares o sociedades pueden por supuesto ser libres de valoración. Sin duda, el historiador, el detective u otros observadores piensan que existe algún valor en realizar su investigación y la descripción resultante, pero esa valoración no necesita de ningún modo entrar en la descripción misma. Todavía menos necesita la descripción aprobar o desaprobar las valoraciones que ella reporta. Pero la situación es distinta si a lo que se aspira es a ofrecer una explicación general de instituciones o prácticas humanas, como el derecho, la amistad, las constituciones, y así sucesivamente. Aquí se confronta la necesidad de seleccionar y priorizar no sólo la investigación en sí misma, sino más bien un conjunto de conceptos (y sus términos correspondientes) de entre (o arriba o abajo) el conjunto de términos y conceptos empleados en la auto-comprensión de los individuos o grupos bajo (o disponibles para) estudio. 
Donde el sujeto o materia de la explicación general proyectada es alguna práctica o institución ideada por (más o menos adecuados ejercicios de) la razón, y dirigida a la deliberación racional de individuos o grupos, normalmente no habrá una buena razón para no priorizar aquellas formas de esa práctica que son más racionales, más razonables, más receptivos a razones, que otras formas de las "mismas" o análogas prácticas o instituciones. El estándar para asignar razonabilidad a este propósito teorético es, en último análisis, el conjunto de criterios de razonabilidad que el teórico descriptivo usaría al tratar con problemas prácticos similares en su propia vida.

Esta necesidad de una selección de conceptos y términos cargados de valor para su uso en una teoría general de realidades sociales como el derecho, ha sido puesto en evidencia en la obra de Max Weber, profeta de la ciencia "libre de valoraciones". Por ejemplo, en su consideración de las formas de dominación ( $H e^{-}$ rrlichkeit) identifica tres tipos puros, centrales, característicos (ideal Typen): carismático, tradicional y racional (burocrático, jurídico). Pero las explicaciones de los dos primeros tipos son enteramente en términos de cómo ambos difieren del tipo racional, cuya racionalidad es auto-evidente para Weber y sus lectores sobre la base de su propio conocimiento de los bienes humanos (aspectos básicos del bienestar humano) y de las verdades prácticas a ellos relacionadas (véase Finnis, 1985: 170-72). La teoría del derecho natural, tal como fue practicada ya en la Ética y la Política de Aristóteles, hace estas valoraciones del teórico de modo abierto y explícito (no oculto y embarazoso), y las somete a debate y escrutinio racional.

Raz, Dickson y otros aceptan que ciertas valoraciones son necesarias, pero niegan que ellas sean morales (Dickson, 2001). Pero una vez que comenzamos a reflexionar sobre razones, ¿pueden contar otras razones salvo las buenas razones? Si una razón moral no es nada más que la razón práctica en su máxima expresión, totalmente crítica y adecuada como razón, las razones morales tendrán un lugar decisivo en la formación de los con- 
ceptos de la ciencia moral, incluyendo los de una teoría general descriptiva del derecho. Y esto parece no haber tenido el efecto temido por Hart, es decir, el remitir el estudio de las leyes e instituciones perversas a otra disciplina distinta (Hart, 1961: 205; 1994: 209). Por el contrario, ellas son el objeto de viva atención en la teoría del derecho, precisamente por su oposición a los sistemas jurídicos (sustantiva y procedimentalmente) moralmente buenos. La Política de Aristóteles, si bien en definitiva es metodológicamente imperfecta, es un primer testimonio de este tipo de reconocimiento clarividente y de la descripción de formas, prácticas e instituciones sociales irrazonables en el marco de una teoría descriptiva orientada por los juicios morales del teórico social.

Por otra parte, la teoría social descriptiva es sólo un aspecto subordinado de las teorías del derecho natural. Su enfoque principal es típicamente el de identificar las condiciones bajo las cuales el derecho está justificado, tanto en el sentido de que el derecho puede y ha de ser preferible a la tiranía o a la anarquía o aun al más benevolente "gobierno de los hombres", como en el sentido de que tal o cual principio jurídico, institución o norma pueden ser juzgados como preferibles a razones alternativas o a pretendidas razones para la acción. Como dice Green (2006):

Los argumentos valorativos son, por supuesto, centrales a la filosofía del derecho genéricamente considerada. Ningún filósofo del derecho puede ser solamente un positivista jurídico. Una teoría del derecho completa requiere también una explicación de qué tipo de cosas pueden considerarse como méritos del derecho (¿puede el derecho ser eficiente o elegante tanto como justo?); cuál es el papel que el derecho ha de jugar en la adjudicación (¿las normas válidas deben ser siempre aplicadas?); qué título tiene el derecho a nuestra obediencia (¿existe un deber de obediencia?); o también de cuestiones centrales como qué normas debemos tener o si hemos de tener leyes pura y simplemente. El positivismo jurídico no aspira a responder estas cuestiones, a pesar de que su reclamo de que la existencia y contenido del derecho depende sólo de hechos sociales sí les da forma. 
No sería mejor decir: ¿ningún filósofo del derecho necesita, o habría de, ser un positivista jurídico? Porque la dependencia del derecho de los hechos sociales es totalmente reconocida, e inclusive explicada, por las teorías del derecho natural. Y esto no es una "concesión" de parte de los teóricos del derecho natural, ya que sus posiciones principales fueron articuladas por Tomás de Aquino varios siglos antes de que emergiera el positivismo jurídico con su desafío a (lo que tomaron por ser) la teoría del derecho natural. La críticas positivistas a la teoría de la ley natural, cuando no descansan sobre el escepticismo acerca de la posibilidad de juicios morales, un escepticismo explícitamente confutado $(d i$ savowed) en el pasaje anterior, descansa sobre malos entendidos de ciertos pasajes de las obras de teóricos del derecho natural. Sobre estos malentendidos, véase Finnis, 1980: 23-55; Soper, 1992.

Una vez más: ¿cómo pueden cuestiones fundamentales como "¿hemos de tener derecho en definitiva?" ser "informadas" por la tesis positivista de que la existencia y contenido del derecho depende sólo de hechos sociales? La propuesta de Green ¿no invierte el orden razonable de indagación y reflexión? Las necesidades sociales básicas y las circunstancias sugieren fuertemente a la gente, virtualmente en todos los tiempos y lugares, que deben elaborar y conservar ciertas normas del tipo de las que llamamos derecho, normas que dependen directamente y en su mayor parte de hechos sociales, como la costumbre, la legislación autoritativa y la adjudicación. La filosofía jurídica reformula y clarifica críticamente ese razonamiento práctico elemental, algo que Hart hizo en su libro de 1961, donde construyó una consideración descriptiva y explicativa del derecho (es decir, que refina su y nuestro concepto o comprensión del derecho) a través de la explicación de cómo las normas difieren de los hábitos, de cómo los poderes tienen diferentes funciones y diverso valor social que las obligaciones, y de ese modo no son aptos para reducirse a obligaciones, y cómo las reglas "primarias" que condenan la violencia extrema, el robo y el fraude necesitan, en razón de su falta de movilidad, y de certeza en su contenido y su aplicación, ser suplementa- 
das por reglas "secundarias" de reconocimiento, adjudicación y cambio, el suplemento remedial que incluye a una sociedad en el dominio del gobierno del derecho y de un sistema jurídico.

¿No pueden estos elementos del libro de Hart ser tomados como una instancia de una teoría del derecho natural, realizada de modo primariamente descriptivo (más que primariamente justificatorio), y con una indagación incompleta de los recursos de la razón práctica, recursos a los que se echa mano (draw upon) en una completa descripción explicativa general del derecho? ¿No es que la descripción de Hart, a pesar de no ser completa, funciona tan bien como lo hace precisamente porque exhuma algunas justificaciones elementales concebidas y puestas en uso por la gente cuyas actividades proveen el material para las descripciones? ¿No comparte él la metodología profunda de Aristóteles y de la tradición del derecho natural (Finnis, 2003b) al hacer que la identificación de qué es el derecho (del "concepto de derecho") dependa de su explicación de por qué el derecho es una respuesta racional a las comunes necesidades humanas?

Nada de esto significa decir que una teoría jurídica sólida (sound), del tipo de la explicada en este trabajo, necesite ser llamada "teoría del derecho natural". Como toda filosofía, debe ser hecha considerando proposiciones, no etiquetas.

\section{OTROS ELEMENTOS DE LA TEORÍA DEL DERECHO NATURAL}

Pensada como parte de una teoría comprehensiva de la razón práctica, que está ordenada a dirigirnos al bien común de cada una de nuestras comunidades y de sus miembros, cualquier teoría jurídica del derecho natural aporta al derecho todas las tesis propuestas y defendidas por las partes política y moral de la teoría del derecho natural y en una comprensión profunda de la formación humana y de las características durables de nuestras circunstancias. Por ello, además de las cuestiones enumeradas por Green, tal 
como fue citado en la sección 5 más arriba, cuestiones como las tres que siguen (véanse otras en Finnis, 2002) son abordadas por la teoría del derecho natural como integrantes de la ciencia jurídica, de la teoría y de la filosofía del derecho.

\section{La intención en la acción y la expresión}

Las normas jurídicas son proposiciones de la razón práctica aptas para ser tomadas como directivas en las deliberaciones de los sujetos jurídicos individuales en vistas al juicio, la elección (decisión) y la acción (incluyendo la tolerancia elegida). Por ello, una teoría del derecho sólida tendrá una comprensión integrada y crítica de la estructura de la acción electiva, especialmente de las relaciones entre la intención de los fines, la adopción de los medios, el carácter dual de casi todos los fines que son también medios, y de casi todos los medios que son también fines, y de la necesidad y posibilidad normal de elegir libremente entre opciones que suponen o prometen beneficios y desventajas inconmensurables (o incompletamente conmensurables) (Finnis, 1997) con los beneficios y desventajas de las opciones alternativas. Una comprensión como esa clarificará las muchas veces rudimentarias explicaciones dadas en la dogmática jurídico-criminal (tanto en los casos judiciales como en los libro de texto) sobre el actus reus y el mens rea, explicaciones que muchas veces fallan al distinguir entre la acción como una porción de conducta física y convencionalmente demarcado, y la acción como la realización de la elección de una opción, es decir, de una proposición formada, y por lo tanto dotada de una descripción privilegiada, en las deliberaciones del sujeto actuante.

La diferencia entre los medios (o fines) intentados o elegidos y los efectos previsibles o completamente previstos ("efectos colaterales"), así como la consecuente diferencia entre los estándares morales y los presuntivamente jurídicos, aplicables respectivamente a efectos queridos y no-queridos, es psicológica y mo- 
ralmente real. Pero esto es muchas veces distorsionado por una dogmática jurídica simplista, muy opuesta al riesgo (muy real) de que los acusados recurran a evasivas o mentiras acerca de lo que tienen en mente. Lo que cuenta y puede frecuentemente ser inferido a pesar de las evasivas o mentiras, es la descripción del acto bajo la cual el comportamiento elegido es atractivo para el acusado en sus deliberaciones reales (como distintas de las descripciones racionalizadas del acto, adoptadas para presentar esa motivación bajo una mejor luz).

La realidad de la intención en el distinto pero relacionado campo de la comunicación de sentido será también explorada y defendida por una teoría jurídica del derecho natural. Esto no implica un originalismo simple y no-cualificado en la interpretación constitucional, o una simple negación de la insistencia, característica de la dogmática jurídica, sobre que la intención de las partes al realizar declaraciones o acuerdos ha de ser establecida "objetivamente (no subjetivamente)", es decir, con referencia a lo que un observador razonable habría tomado como el significado de la declaración en cuestión. Porque un observador de este tipo (y por lo tanto, el punto de vista "objetivo") dará presuntivamente primacía en esta interpretación a lo que (en la medida en que el observador lo puede discernir en las circunstancias de la declaración realizada [=afirmación]) la declaración del autor ("subjetivamente") realmente significa (=intenta expresar o establecer).

\section{Responsabilidad y castigo}

La responsabilidad criminal (culpa) se da primariamente por acciones y consecuencias intentadas por el acusado. La responsabilidad por negligencia es relativamente excepcional en el derecho criminal moderno, aunque es la forma predominante de responsabilidad en el actual derecho de las compensaciones (“derecho civil") (los deberes y estándares de cuidado usados para atribuir responsabilidad por daños (tort)/delictual/civil son 
en parte directamente morales y en parte convencionales - en ninguna parte son sólo basados en fuentes sociales, en el sentido de fuentes dotadas por el positivismo jurídico de una primacía incondicional-).

La enunciación jurídica de las normas del derecho criminal/ penal (mayormente prohibiciones) tiene como su principal objetivo la eliminación o al menos el desaliento de las formas de acción (u omisión) especificadas. En esta fase de la institución jurídica del derecho criminal y del castigo, el objetivo puede ser llamado disuasión (deterrence). El hecho de que este objetivo funcione en parte forzosamente por aplicación de la sanción amenazada en el caso de violación y condena, no supone, por supuesto, que la disuasión sea el fin primario o formativo del castigo. Por supuesto, la institución del castigo tiene su principal sentido y justificación no en la disuasión, sino en la restauración de ese balance presuntamente equitativo de cargas y beneficios que los culpables destruyeron, precisamente al optar por elegir sus propios propósitos y ventajas en lugar de refrenar su conducta para evitar la violación del derecho. Al escoger esa opción preferencial, los culpables se otorgaron a sí mismos una ventaja sobre todos aquellos que refrenaron su conducta de modo de respetar el derecho.

De ese modo, los infractores disturbaron el balance presuntivamente equitativo de ventajas y desventajas entre ellos y los respetuosos del derecho. Por lo tanto, el propósito primario del castigo es el de restaurar razonablemente ese balance disturbado, privando a los infractores condenados de su ventaja injustamente obtenida - excesiva libertad de acción - imponiéndoles medidas, castigos, cuyo propósito preciso es restringir su libertad de acción, sea por multas o prisión, proporcionalmente al grado en el cual ellos satisficieron su auto-preferencia. En este sentido, el castigo busca asegurar que, en el periodo de tiempo que va desde antes del delito hasta el del castigo, nadie gane delinquiendo una ventaja sobre sus conciudadanos.

Por ello, mientras la compensación del derecho civil (daño, delito, etcétera) rectifica el balance roto de ventajas y desventajas 
entre los damnificados y los perpetradores del daño, el castigo en el derecho criminal (penal) rectifica la relación entre los delincuentes y los miembros de la comunidad respetuosos del derecho. La justificación retributiva (propósito general justificatorio) del castigo explica por qué la competencia mental y el dolo o mente criminal (mens rea) son pre-condiciones estándar de la culpabilidad criminal y del merecimiento del castigo. Esta justificación es compatible con objetivos concurrentes como la disuasión, protección o reforma, que aparecen como efectos colaterales suplementarios de la sentencia retributiva, y con propósitos organizativos de medidas específicas y de caracteres, e. g., del régimen de prisión. Ambos presuponen y refuerzan la realidad de que la comunidad política en cuestión se presenta frente a los delincuentes y los respetuosos del derecho como siendo nuestra comunidad.

\section{Cada sistema jurídico es de y para una comunidad política particular}

El examen de (i) cómo un sistema jurídico deviene independiente de otro mediante un proceso legítimo y (ii) cómo partes de un sistema jurídico (e. g., su Constitución o sus normas para identificar a los agentes públicos) son reemplazadas por el ilegítimo proceso de un coup d'état o revolución, demuestra (véase Raz, 1979: 100-109) que la identidad de un sistema jurídico subsistente como uno y el mismo sistema de normas jurídicas no puede ser explicado (o coherentemente descrito) por una explicación que se refiera sólo a las normas y a sus interrelaciones como normas validadas y normas validantes. La identidad no-simultánea de un sistema jurídico es una función de la identidad subsistente de la comunidad de la que es su sistema jurídico.

La teoría jurídica está sub-alternada a la comprensión histórica (incluida la auto-comprensión) de una comunidad y de sus miembros de ser esta comunidad - paradigmáticamente este Estado-nación - más que una secuencia accidental o aglome- 
ración de personas o eventos, y esta comprensión deberá ser en cierta medida sustancial no-dependiente de las normas jurídicas que la comunidad tuvo éxito en constituir para sí misma y sus miembros. Sin lugar a dudas, el propósito compartido de vivir juntos bajo el gobierno del derecho y la memoria compartida del reconocimiento compartido de ese derecho como nuestro derecho son normalmente componentes importantes de esa comprensión compartida de la identidad político-comunal y jurídica. Pero otros propósitos compartidos, recuerdos y disposiciones para actuar deben estar también sustancialmente presentes si el fenómeno de la legítima independencia y del cambio constitucional revolucionario han de ser como lo son.

El realismo crítico de la teoría del derecho natural, evidenciada en su aproximación a la realidad de la intención, como distinta de la previsión y la inatención, y de la elección autopreferencial y de las diferentes relaciones entre (i) criminal y respetuoso del derecho, y (ii) causante del daño y víctima, la habilita de modo similar a emprender una reflexión crítica, en el marco de la teoría jurídica ampliamente entendida, acerca de los tipos de comunidad capaces de sostener y ser ordenadas, al menos en parte, por los sistemas jurídicos. 


\section{REVISANDO LOS FUNDAMENTOS DE LA RAZÓN PRÁCTICA*}

Nuestras investigaciones, reflexiones y comunicaciones son acciones. A veces son meramente espontáneas, pero con mucha frecuencia, como sucede con otros tipos de acción, suponen una deliberación, elección y esfuerzo continuo, todo lo cual hace perceptible la propia capacidad de respuesta a las oportunidades. Este trabajo trata una vez más sobre algunos de los principales elementos de esa capacidad de respuesta.

Hacer derecho nos sumerge tanto en actividades de razón práctica, al tener que pensar qué elegir o hacer, cuanto en cierta reflexión sobre el contenido y estructura de ese pensamiento. Como dice el Aquinate, las leyes, sean extremadamente generales o muy específicas, son todas "proposiciones universales de la razón práctica". ${ }^{1}$ Desde que se comienzan los estudios jurídicos, especialmente en el ámbito del common law, trabajamos para identificar las proposiciones jurídicas que son correctas en ese ámbito (digamos, válidas). Para uno mismo y para otros, mostramos tanto el contenido como la corrección de esas proposiciones por referencia a otras proposiciones anteriores, escogiendo condiciones para la validez

* Publicado originalmente como "Foundations of practical reason revisited", American Fournal uf Furisprudence, South Bend, núm. 50, 2005, pp. 109-131. Publicado en castellano en Persona y Derecho, Pamplona, núm. 64, 2011. Traducido por Carlos I. Massini-Correas. Colaboración idiomática de Ángeles Massini Pontis. Revisado por la redacción de la revista.

1 Summa Theologiae, I-II, q. 90, a. 1, ad 2. 
de una proposición jurídica, algunas de las cuales son denominadas por los juristas "fuentes del derecho" (de esta jurisdicción) y otras "principios de interpretación". Algunas teorías jurídicas de los siglos XIX y XX, como las de John Austin y Hans Kelsen, podrían interpretarse en el sentido de que todas las condiciones de validez jurídica se refieren a la forma y al hecho originante: formas de transacción o procedimiento, como que la promulgación pueda datarse en una legislatura en particular. Esta postura tiene un atractivo inicial para los juristas, acostumbrados como están a buscar el "origen del título" (root of títle) en forma de transacción datable, como venta, traspaso, inscripción en el registro, u otras por el estilo. Pero ha resultado ser tan equivocada como autodestructiva, al negar que los criterios o premisas para juzgar la validez o corrección de las proposiciones jurídicas deban hacer referencia también al contenido, esto es, al tipo de conducta que la proposición cuya validez está en cuestión busca imponer o autorizar, así como a las vías a través de las cuales otras proposiciones jurídicas imponen o autorizan esas conductas.

Las teorías que lo niegan se equivocan al suponer que pueda explicarse la validez del derecho, tanto en el pensamiento como en la práctica jurídica, sin que se reconozca la centralidad en ambos niveles, de criterios de contenido tales como: (i) que las proposiciones de derecho supuestamente válidas no deben contradecir o ser inconsistentes entre sí en la práctica; (ii) que las proposiciones validadas por transacciones jurídicas particulares y datables continúan siendo válidas salvo y hasta que se produzca algún acontecimiento invalidante, y (iii) que las transacciones posteriores y sus consecuencias normativas prevalecen sobre las transacciones precedentes de la misma índole. Ninguno de estos criterios se asienta sobre ninguna proposición fáctica o evento originante y ninguno es un requisito lógico, ya que ningún requisito lógico excluye la posibilidad de que cierta comunidad, y por ende cada uno de sus miembros, esté simplemente confundido y/o que sus gobernantes emitan reglas contradictorias para confundir a los gobernados. 
Las teorías que buscan excluir de la "ciencia jurídica" todos los criterios no-formales de validez fracasan en sus propósitos explicativo-descriptivos. En cualquier comunidad, los criterios de determinación de la validez empleados en su derecho hacen referencia a consideraciones de contenido, tales como que los sujetos de derecho necesitan recibir directivas coherentes y practicables, que la ley debe cambiar cada cierto tiempo, que los requerimientos y autorizaciones del derecho deben ser conocidos previamente por los sujetos, que las disputas deben ser resueltas, que se deben facilitar las transacciones y su efectividad, que las incorrecciones deben ser rectificadas, las expectativas razonables respetadas, el fraude desincentivado, y así sucesivamente. Los criterios de contenido, como los principios generales del derecho que acabo de mencionar, son llamados a veces, y razonablemente, principios de interpretación. Dan forma al modo en que cualquier jurista entiende las declaraciones u otros acontecimientos originantes que pretendan dar validez a proposiciones jurídicas en una jurisdicción particular, y también dan forma a cualquier afirmación jurídica de esa supuesta validez. Todos estos criterios generales, y aun las más específicas instituciones y las reglas que las hacen efectivas en las distintas comunidades, asumen presupuestos acerca de lo que sería bueno para esa comunidad, y qué sería dañoso (inestabilidad, inseguridad, disputas irresolubles, dificultad para llegar a acuerdos que eviten conflictos futuros, falta de respuesta a las nuevas amenazas y oportunidades, etcétera).

Dicho brevemente: las fuentes del derecho incluyen no sólo sentencias relevantes de los más altos tribunales, leyes aplicables y documentos constitucionales, escritos de juristas y principios y estructuras de la lógica, sino también principios que articulan lo que en el pensamiento jurídico de cada uno se nos aparece (como se lo ha parecido a muchos otros) como requerimientos de una conducta civilizada, decente y humana. E incluso, comprender un sistema jurídico, y por supuesto participar en su mantenimiento, aplicación y desarrollo, supone comprometerse con la razón práctica de un modo que invita a ser conscientes de (y da 
la oportunidad de reflexionar sobre) su estructura, forma, procedimiento, criterios y lógica, como un conjunto de razones para la acción que cuentan como razones jurídicas, en razón de su función de escoger en el sistema bienes posibles y maneras de alcanzarlos, así como daños posibles y modos de evitarlos. A veces, sin duda, esta referencia a bienes y daños es inmediata, pero pienso que más comúnmente ha de ser discernida "remontándose" desde la proposición jurídica específica hasta los principios de los cuales "deriva"; principios que articulan esa referencia como parte del proceso racional de interpretación y validación, por el cual, como buenos juristas, podemos justificar la afirmación de que determinada proposición ("p", y es parte de nuestro derecho que "p") es una proposición de derecho válida o verdadera (al menos del derecho de esta jurisdicción).

De este modo, un jurista, particularmente en la tradición jurídica del common law, ${ }^{2}$ puede encontrar atractiva una explicación de la

2 Los juristas de la tradición romanística moderna se inclinan a llamar al objeto de su disciplina droit, o derecho, o diritto, Recht, ius, "right", términos que su tradición de teoría interpretativa opone a lex y sus derivados loi, ley, "law". Indudablemente, lo que es justo entre las personas en una materia dada concierne directamente a la ley. Pero esas relaciones no son tan fundamentales que no puedan ser explicadas y mostradas como just(ificadas) por referencia a los principios de la razón práctica (las proposiciones más universales acerca de lo que ha de ser realizado u omitido). Desafortunadamente, aun la tradición inglesa de traducción e interpretación de Tomás de Aquino se corrompió en este punto, como muestra la muy discutible traducción dominicana de la afirmación del Aquinate de que lex is aliqualis ratio iuris, como "law is an expression of right", cuando la traducción obvia y correcta es algo así como "law is (in the nature of) a foundation of or informing idea behind right(s)" justamente, como explican las afirmaciones precedentes del Aquinate, del modo en que la ratio de un edificio es lo que preexiste en la mente del constructor y regula (provee la "regla" para) la labor de construcción. Como se dice en la Summa Theologiae, II-II q. 57, a. 1, ad 2: "sicut eorum quae per artem exterius fiunt quedam ratio in mente artificis praeexistit quae dicitur regula artis, ita etiam illius operis iusti quod 
razón práctica como la que el Aquinate ofrece en su argumentación acerca del derecho, en la que trata cada ley positiva como una proposición derivada de los primeros principios de la razón práctica, ya sea a modo de "conclusión", o bien, mucho más comúnmente, por la especificación, racional pero no deductiva, que él llama determinatio. ${ }^{3}$

Pero no es cuestión de aceptar la explicación de Tomás de Aquino simplemente porque es la suya, o porque incorpora la de Aristóteles (y Platón), o bien porque se ajusta a algunos de los principales aspectos de los hábitos de pensamiento de los juristas. Todo en ella ha sido cuestionado y para ser reutilizado (si lo merece y en la medida en que lo merezca) ha de ser analizado a la luz de esos cuestionamientos y críticas.

Se supone comúnmente que el modo fácil de mostrar qué se quiere decir con "razón práctica" o "racionalmente exigido", es señalar los casos en los que optando por, y haciendo o realizando $\mathrm{X}$, se va a alcanzar lo que se quiere (se va a satisfacer el propio deseo, o el deseo dominante aquí y ahora). La necesidad de medios para lograr un fin establecido por el propio deseo, se toma paradigmáticamente como necesidad, racionalidad y normatividad prácticas ("práctica", al menos entendida como distinta de, por ejemplo, la normatividad lógica). Estas afirmaciones pueden calificarse como humeanas, o neo-humeanas, y efectivamente lo

ratio determinat quedam ratio praeexistit in mente, quasi quedam prudentiae regula; ideo lex non est ipsum ius, proprie loquendo, sed aliqualis ratio iuris". La frase reemplazada aquí por elipsis obscurece las aguas recurriendo al sentido (específico del derecho romano) de ley como algo escrito, pero el argumento es claro en general, y debería presidir cualquier traducción de ratio iuris.

3 Sobre la determination, véase Summa Theologiae, I-II, q. 96, a. 4c; Finnis, J., Natural Law \& Natural Rights, pp. 282-290, 295-296; "On «the Critical Legal Studies Movement»", American Fournal of Furisprudence, 1985, 30, pp. 21-42; también en Oxford Essays in Furisprudence, ed. John Bell \& John Eekelaar, tercera serie, Oxford, Clarendon Press, 1987, pp. 145-165; "Natural Law \& Legal Reasoning", George, R. P. (ed.), Natural Law Theory: Contemporary Essays, Oxford, Clarendon Press, 1992, pp. 134-157; "The Truth in Legal Positivism", George, R. P. (ed.), The Autonomy of Law: Essays in Legal Positivism, Oxford, Clarendon Press, 1996, pp. 195-214. 
son, ${ }^{4}$ pero el mismo Hume da una versión desconcertante de la idea de razón práctica:

Entiendo que no es contrario a la razón preferir la destrucción de todo el mundo a un arañazo en mi dedo. $\mathrm{Ni}$ es contrario a la razón elegir mi ruina total para evitar la mínima incomodidad a una persona de la India completamente desconocida para mí. Tampoco es contrario a la razón preferir un bien pequeño pero conocido a uno mayor, y tener un afecto más ardiente por el primero que por el segundo. Un bien trivial puede, en ciertas circunstancias, producir un deseo superior del que produce el más grande y más valioso disfrute. ${ }^{5}$

Esta afirmación de Hume me impresionó hace tiempo como una admisión de lo que implica su explicación de la razón. Esto es, que no es contrario a la razón que el deseo de un bien trivial me desvíe de hacer lo que es necesario para alcanzar el más grande y valioso disfrute propio, o para salvar a cada uno (o al mundo entero) de la destrucción. Es decir, que la "prudencia", en su estrecho sentido moderno de auto-interés, no es más requisito racional (ni siquiera motivo racional) que la moralidad, tomada en el estrecho sentido moderno que establece su contenido por un contraste implícito con el autointerés.

No se trata aquí de que Hume se haya dejado llevar por el amor a la paradoja o al efecto retórico. No es más que una de las formas en las que Hume niega, o se ve obligado a negar, la existencia de la razón práctica, a favor de un cuadro en el que

4 En realidad son más que neo-humeanas, tan importantes han sido tanto sus fuentes como su influencia; acerca de los elementos neo-kantianos y weberianos (por no mencionar los nietzscheanos) en la "moderna distinción hechosvalores" y la llamada "positividad de los valores", véanse mis reflexiones sobre el Max Weber de Anthony Kronman (Stanford, Stanford University Press, 1983), en "On «Positivism» and «Legal Rational Authority»", Oxford Fournal of Legal Studies, 5, 1985, pp. 74-90.

5 Hume, D., A Treatise on Human Nature, ed. L. A. Selby-Bigge, rev. P.H. Nidditch, Oxford, Oxford University Press, 1997, p. 416 (la cursiva es del autor). 
simplemente hacemos lo que hacemos, y en el que lo que de hecho hacemos, en cada situación, muestra qué es lo que deseamos (queremos) más; muestra cuál es nuestro fin (dominante) y los medios que creemos disponibles y eficaces. En un cuadro como éste, simplemente no hay lugar para la normatividad, para ser conducido o impelido a adoptar ciertos medios (en razón de su eficacia para el propio fin (o fines) que, no obstante, uno podría (irracional o al menos irrazonablemente) no adoptar. Lo que cuenta es el deseo dominante de cada uno en cada momento, que puede muy bien ser el deseo de evitar las cargas y/o los efectos negativos colaterales de los medios necesarios para alcanzar lo que fue, hasta hace muy poco, el propio deseo dominante. El es de "es lo que en este momento más deseo", así como el es de "es aquello que yo más deseaba hasta hace un momento" (y, también, el es de "mi inteligencia es del tipo que encuentra medios para conseguir fines"), no proveen de fundamento para un debe. De este modo, la mecánica del deseo (finalmente reducible a algo tan crudo como Hobbes lo pinta) ha eliminado todo el espacio conceptual que podría haber sido ocupado por la razón práctica. Una razón que es esclava del deseo puede indicar modos astutos para satisfacer alguno de los propios deseos, pero no proporciona razones para el obrar.

Estas implicaciones de la posición humeana han sido metódica y eficazmente revisadas por Christine Korsgaard (1997) en su crítica a los presupuestos estándar sobre la normatividad de la razón instrumental, y más particularmente sobre la normatividad o racionalidad práctica de la prudencia (auto-interesada). ${ }^{6}$ Allí llega a una conclusión, pienso yo, fuerte pero justificada. No puede haber (sostiene) racionalidad práctica en absoluto (ni tampoco imperativos hipotéticos, ni medios racionalmente exigidos) salvo que existan "algunos principios racionales que determi-

6 Korsgaard, C., "The Normativity of Instrumental Reason", en Ethics \& Practical Reason, Garrett Cullity \& Berys Gaut, Oxford, Oxford University Press, 1997, pp. 214-254. 
nen qué fines son merecedores de preferencia o persecución", "principios normativos que impongan la adopción de fines", "algo que otorgue estatus normativo a nuestros fines", ${ }^{8}$ proporcionando "razones incondicionales para tener ciertos fines, así como principios incondicionales de los cuales se derivan esas razones"9 (esto se puede expresar del siguiente modo: si no se llevan las razones hasta el final, no hay manera de que puedan entrar imperativamente en nuestras deliberaciones, porque "salvo que algo agregue normatividad a nuestros fines, no podrá exigirse la adopción de los medios que conducen a ellos". ${ }^{10}$ Más aún, esos fines han de ser "buenos en un sentido que vaya más allá de lo deseable en un caso particular". ${ }^{11}$ Porque "yo debo tener algo que decirme a mi mismo acerca de por qué estoy [queriendo un fin, y estando comprometido y permaneciendo comprometido con él, aun frente a deseos que podrían distraerme y debilitarme, que pudieran disuadirme]; algo mejor [que decirme a mí mismo] que el hecho de que esto sea lo que quise ayer" 12 [o hace un momento; o incluso, si hay sentimientos encontrados, en este preciso momento]).

Podemos resumir las observaciones de Korsgaard diciendo que las razones básicas para querer (para elegir y realizar la propia elección) establecen qué es bueno en aquello que la acción procura, y bueno de tal modo que pueda decirse que proporciona una

7 Ibidem, p. 230.

8 Ibidem, p. 250.

9 Ibidem, p. 252.

10 lbidem, p. 251.

11 Ibidem, pp. 250 y 251. Korsgaard, en las páginas 251 y 252, está tentada de retractarse de esto para aceptar como "acto heroico existencialista", "simplemente tomar la propia voluntad en un cierto momento como normativa, y comprometerse uno mismo para siempre con el fin seleccionado en ese momento", "sin otra razón que la que uno lo quiere así". Pero entonces debería de conceder que, salvo que una persona así considere que hay algo de valioso haciendo eso, algún bien o razón para hacer eso, ese "acto de compromiso" y de subsiguiente "tomarlo como normativo" no es racional sino irracional.

12 Ibidem, p. 250. 
razón incondicional para actuar en persecución de ese bien(es), o al menos para evitar lo que podría negar ese bien(es). Esas razones que identifican bienes son incondicionales; interpreto a la autora no en el sentido de que sean "categóricos" o "morales", sino en el de que son no-dependientes, no necesitan una justificación o validación (son primarios, intrínsecos, básicos).

\section{III}

Ahora bien, Korsgaard (por lo que sé), como otros filósofos contemporáneos, se abstiene de formular y responder a la cuestión de si podemos especificar las razones básicas para querer y hacer, y considerarlas coordinadamente como un conjunto. En su caso, esta abstención puede estar relacionada con la tradición filosófica en la que explícitamente se sitúa. La influencia de esta tradición (tan importante si queremos entender también gran parte de la teología moderna) puede verse cuando, en sus Oxford Lectures de 2002, al abordar la cuestión de si (tal como ella lo formula) "los deseos y las inclinaciones son meras respuestas a las propiedades benéficas de los objetos, y sólo tenemos que hablar de esas propiedades benéficas cuando hablamos de nuestras razones, y no de los deseos o las inclinaciones en sí mismos". Su respuesta es: "como kantiana, no estoy de acuerdo" y desarrolla ese argumento de dos maneras. Primero:

en Kant, [i] los caracteres de los objetos que deseamos y que mencionamos cuando explicamos por qué valoramos esos objetos, no les darían valor si no fuera por el modo en que esos objetos están relacionados con la fisiología y la psicología humanas. [ii] En la base de cualquier deseo o inclinación, no importa lo argumentativamente que lo defendamos, existe una adecuacióna-nosotros básica, que es cuestión de naturaleza y no de razón. [iii] El valor es relacional y con lo que está relacionado es con nuestra naturaleza. 
Con respecto a este primer modo de desacuerdo, quisiera remarcar que las tres proposiciones que ella identifica aquí como kantianas, tal como están establecidas, me parecen sólidas, salvo por el contraste implícito en "de naturaleza y no de razón"; y ninguna de ellas proporciona suficientes razones como para dudar de que los deseos e inclinaciones inteligentes sean respuestas a las propiedades benéficas de los posibles objetos de deseo, deliberación y elección.

En cuanto al segundo modo, apela de nuevo directamente a esa específica tradición y a su maestro: "Como kantiana, creo que son nuestras elecciones las que en última instancia confieren valor a los objetos, aun cuando nuestras elecciones respondan a ciertos caracteres de esos objetos".

Interfiero en esta cita para sugerir que parte del problema que se hace Korsgaard procede de la ambigüedad de la palabra "objeto". En efecto, en la antigua tradición que el pensamiento kantiano (o al menos el de Kant) pretende tanto sostener como criticar, los objetos de nuestra elección son (i) nuestras acciones, (ii) los estados de cosas que las acciones pueden realizar o al menos ocasionar y (iii) la consiguiente plenitud (al menos en parte, si no completamente) de las personas, que es el último objetivo de las acciones y de los efectos que persiguen. En este modo de entender el término "objeto", no cabe el pensamiento de que nuestras elecciones, respondiendo a cierta característica de un objeto, le confieran valor a ese objeto. Menos plausible aún sería si se entiende que el término "objeto" incluye a una persona que podría ser beneficiada o dañada por mi elección y mi acción. Pero para volver al segundo punto de Korsgaard:

$\mathrm{Al}$ elegir objetos, al conferir valor a las cosas que responden a nuestra naturaleza según modos aceptables, un agente afirma su propio valor. Hace que lo que le importa importe absolutamente y, de ese modo, lo hace merecedor de su elección.

[Volveremos en seguida a estas cuestionables afirmaciones, después de dejar que Korsgaard agregue sus propias y bien calculadas salvedades]. 
Pero incluso aunque el mismo agente crea esta teoría kantiana, de ahí no se sigue que deba pensar de sí misma que elige objetos simplemente porque quiere o le gustan. Aún puede hablarse, a sí misma y a otros, acerca de qué es lo que le gusta en estos objetos y por qué. Por ello a pesar de que puede deducirse de lo que digo que elegimos cosas "porque las queremos", de donde la inclinación proveería a la razón, de aquí no se sigue que cuando alguien nos pregunta

[y ese alguien puede ser muy bien "el mismo agente", tal como la misma Korsgaard ha señalado anteriormente sobre ese mismo punto: "yo debo tener algo que decirme a mí mismo"]

(cuando alguien nos pregunta) por qué escogemos algo (no se sigue de aquí que) la respuesta correcta sea "porque lo quería"... (C)uando explicamos los propios valores a otra persona, es muy poco informativo mencionar, como base del valor, el hecho de que uno tenga una inclinación hacia el objeto. El otro lo sabe... (Q)uiere conocer nuestra inclinación, qué es lo que nos conduce al objeto. Y lo especificamos describiendo el incentivo, en la medida de lo posible,

[es decir, proporcionando una representación cargada de motivaciones del objeto, presentándolo como deseable o repugnante de algún modo específico]. ${ }^{13}$

Tomando este pasaje en su conjunto, y dando todo su peso a sus bien calculadas salvedades, en las que se extiende tras los tres primeros postulados, me pregunto si no nos encontramos ante otra manifestación de las sombras de la Ilustración: Hume fundando todo lo referente a la razón práctica (o lo que inocentemente pensamos como tal) en los deseos que están constituidos en nuestra naturaleza, en nuestra "fisiología y psicología humana"; Kant negando que eso pueda justificar la fuerza racional, la normatividad (el carácter prescriptivo o directivo) de cualquier razón para la acción y adscribiendo esa normatividad a la au-

13 Korsgaard, C., Self-Constitution: Action, Identity, and Integrity (The Fohn Locke Lectures, 2002), Lecture Four, "Expulsion from the Garden: the Transition to Humanity", 4.4.4, with 4.1.1, http://wrew.people.fas.harvard.edu/korsgaar/Korsgaard. LL4.pdf. 
to-legislación de la razón; Korsgaard tomando todo esto como "un compromiso de uno mismo" con fines, pero con un Kant incapaz de proveer explicación fundamental alguna acerca de con qué fines resulta racional e inteligente comprometerse. Y en todo ese tiempo, los aristotélicos del momento (como algunos todavía hoy) han sido incapaces de proveer la ayuda que intuimos en la idea de Korsgaard de un "ajustado-a-nosotros básico que es cuestión de naturaleza", porque también ellos lo tratan "como asunto de la naturaleza y no de la razón", ${ }^{14}$ habiendo perdido conexión con la comprensión epistemológica fundacional de Aristóteles y el Aquinate que lamento no haber argumentado como tal en Natural Law and Natural Rights: una naturaleza como la nuestra se conoce entendiendo los objetos que dan sentido a los actos a través de los cuales se realizan las capacidades de un ente de esa naturaleza. ${ }^{15}$

14 Para una afirmación complementaria sobre algunas deficiencias en la tradición neo-aristotélica, véase mi Fundamentals of Ethics, Oxford, Clarendon Press, 1983, p. 32, donde, habiendo mostrado que el punto de vista de Anthony Kenny es que hay "algunos deseos que están más allá de toda pregunta, que simplemente existen como «hechos naturales» acerca de mí mismo o de todos, y que hacen posible el razonamiento y la razonabilidad práctica, sin ser ellos mismos objeto de razón o comprensión", yo continué: "Aquí obviamente hemos unido a Hobbes con Hume. Pero no sólo a Hobbes y a Hume. Una escuela completa de intérpretes de Aristóteles ha afirmado que, cuando Aristóteles decía «la deliberación es acerca de los medios, no de los fines», quería acercarse a aquellos que sostienen que los fines básicos de nuestra acción son provistos, no por nuestra captación inteligente de ciertos objetivos como verdaderamente buenos, sino más bien por los deseos con los que la naturaleza nos ha equipado, o que simplemente tenemos. Y esa escuela de intérpretes ha encontrado apoyo en los muchos neo-escolásticos que piensan que están siguiendo al Aquinate cuando afirman que la prudencia concierne a los medios y no a los fines, y que la sindéresis (el otro aspecto de la razón mencionada por el Aquinate en conexión con este punto) no es una cuestión de comprensión de los fines, sino de intuición de las verdades morales acerca de lo adecuado o lo obligatorio, es decir, acerca de ciertas condiciones para la persecución de los fines (supuesto que los fines de la acción humana son provistos por «inclinaciones» subracionales)" [cursivas en el original].

15 Véase, Fundamentals of Ethics, pp. 20-22; Aquinas: Moral, Political and Legal Theory, Oxford, Oxford University Press, 1998, pp. 29-34, 90-94,102. 
La confusión ilustrada que de aquí se deriva se ve claramente en la oscilación, en este pasaje de Korsgaard, entre (a) la idea de "conferir valor a las cosas que responden convenientemente a nuestra naturaleza", (b) la idea contraria según la cual la respuesta de esas cosas a nuestra naturaleza las hace valiosas previamente a nuestra elección, y convierte esta última en inteligente y (en principio) razonable, y (c) la idea de que como agentes tenemos un valor propio que ha de ser "afirmado", lo que puede significar simplemente "alegado" (libremente afirmado y, por lo tanto, también libremente rechazable), pero que es más natural entender como que es realmente un valor.

¿Qué hacer con la propuesta de que en la acción uno está "afirmando su propio valor"? Primero: tal como creo que ella presumirá, sería irrazonable de mi parte afirmar simplemente, sin razón, que yo tengo mi propio valor, y que lo que me importa a mí importa "absolutamente y es, en consecuencia, digno de mi elección", aunque usted y cualquier otro no tenga ese mismo tipo de valor, y lo que le importe a usted y a otros no importe de la misma manera. Por lo tanto, si no fuera evidente (susceptible de ser afirmado de modo autoevidente) que los otros, al menos algunos de ellos, y lo que a ellos les importa, es valioso de un modo que me da razones incondicionales (si no categóricas u obligatorias) para actuar a favor de ellos, el pensamiento de que yo y mis asuntos tienen ese valor no tendría asidero. Segundo: los sólidos argumentos de Korsgaard contra la interpretación de Hume (y consiguiente negación, buscada o no) de la razón práctica muestran suficientemente bien que mi mero deseo o determinación de tratarme a mi mismo y lo que me importa como dotado de un valor o dignidad inherente (absoluto), provee una razón para hacerlo así. Tercero: decir (o pensar) que tanto yo como lo que es objeto de mi elección tienen valor exige ver si en esa proposición hay algo de interés, algo digno de ser creído, sin que haya que introducir condiciones y exclusiones. Para ser dignos de elección, los objetos de mis elecciones, ¿no deben tener un valor distinto del que se atribuye al objeto perseguido por un borracho que 
busca una farola para una serenata, o bien (para cambiar la naturaleza de la duda) al del objeto de un estafador crudamente egoísta y cruel, que adula para engañar, violar, robar y matar por el sólo deseo de hacerlo? ¿Y puede mi valor contar algo en una deliberación o en una reflexión, a menos que sea diferente del de agentes tales como un cáncer vigoroso, o el de un cocodrilo zambulléndose en su guarida con su presa aún viva, el niño de alguien, entre sus fauces? De modo más pertinente aún, ¿¿no es claro que los pensamientos acerca del valor de los propios objetivos, y de la identidad que uno inevitablemente adquiere al perseguirlos, no pueden ser afirmados razonablemente a menos que en algunos casos pudieran equivocarse? Que pueden hacerlo es algo que hemos aprendido todos (al menos por experiencia) desde el comienzo de la edad de la razón, a los seis o siete años, o cuando haya sido.

\section{IV}

Siguiendo al Aquinate, y la reformulación de su pensamiento por Germain Grisez, así como la evidencia de (inter alia) la antropología empírica, Natural Law E Natural Rights ofrece una lista de razones básicas para querer (desear inteligentemente) y hacer. Las discusiones de la ciencia jurídica acerca del libro han tendido a focalizarse demasiado exclusivamente en esa lista, como si las respuestas a todas las cuestiones decisivas estuvieran allí. Los filósofos, por el contrario, han tendido a ignorarlas; muchos de ellos quizá porque asumen que una enumeración tan directa y sencilla no puede ser una respuesta verdadera a los problemas estudiados por Hobbes, Hume, Kant o Nietzsche, aunque otros como Martha Nussbaum y Amartya Sen han rechazado esa suposición y propuesto su propia lista, también breve y sustantiva. ${ }^{16}$ En 1995-7,

16 Véase la amplia y documentada discusión de sus listas (y de la mía) en Alkire, S., Valuing Freedoms: Sen's Capability Approach and Poverty Reduction, Oxford, Oxford University Press, 2002. 
Sabina Alkire sometió estas listas, que en parte se solapan, a un test de conformidad con la auto-comprensión de las mujeres en la villa de Arabsolangi, en el lejano interior de Afganistán, tal como lo describe en su libro doctoral Valuing Freedom.

Tomás de Aquino pensó en estas razones básicas como los primeros principios prácticos o principios de la razón práctica; "principios" tanto como proposiciones de la mayor generalidad y comprehensividad, cuanto como fuentes de todo pensamiento inteligente acerca de qué hacer. Son los "principios de la ley natural o del derecho natural" que los juristas andan buscando. Pero a pesar de que son pensados precisamente como una situación final en una búsqueda jurídico-práctica de las raíces de las exigencias del derecho, lo que quiero subrayar en el resto de este trabajo es que identificarlos y afirmarlos es sólo un comienzo.

¿Cuáles son las cualidades de pensamiento y de respuesta que están involucradas en el trayecto desde los primeros principios hasta los juicios relativamente específicos aptos para ser leyes en una comunidad política justa? Algunas de las cuestiones que rodean a esta pregunta han sido exploradas recientemente por Terence Irwin en "The Scope of Deliberation: A Conflict in Aquinas" (1990) ${ }^{17}$ y "Practical Reason Divided: Aquinas and his Critics" (1997). ${ }^{18}$ El primer artículo sugería que el Aquinate sostiene incoherentemente estas dos afirmaciones: (A) que la deliberación es siempre acerca de los medios, no de los fines, y que la virtud intelectual del buen deliberar (prudentia) no tiene papel alguno en la identificación (y adopción) por la persona virtuosa del fin o fines correctos, que sería más bien asunto de esa captación no-deliberativa de los fines básicos y de los primeros principios prácticos que el Aquinate denomina sindéresis y que afirma que es participada del mismo modo por los viciosos y los virtuosos; y al mismo tiempo (B), que la prudentia tiene (necesariamente) un papel en esa identificación (y adopción) del fin o fines correctos

17 Review of Metaphysics, 44, 1990, pp. 21-42.

18 En Cullity \& Gaut, Ethics \& Practical Reason, pp. 189-214. 
que distingue a la persona virtuosa de la viciosa. En su segundo artículo, Irwin abandona tácitamente esta afirmación acerca de la inconsistencia de Tomás de Aquino, y encuentra la necesaria conciliación en la idea de que existe una "macro-prudencia", la virtud gubernativa del buen deliberar acerca de todo lo relacionado con lo que constituye, por así decirlo, la felicidad en general (206); la sindéresis, que comparten tanto los viciosos como los virtuosos, nos dice nada más ni nada menos (según la tesis de Irwin), que para todos y cada uno de nosotros hay un "fin universal" (203-204), "el bien final de los seres humanos con la naturaleza que les es propia" (202); corresponde a la macro-prudencia colocarnos en el camino de la acción correcta, determinando ese fin universal y ese bien final.

Pero no es esa, pienso, la manera correcta de sintetizar las afirmaciones del Aquinate (cuya inconsistencia [en el nivel de las afirmaciones] ha interesado a sus seguidores durante siglos $)^{19}$ en un conjunto coherente de proposiciones acerca del papel de las virtudes intelectuales (no menos morales; sumariamente, la prudentia) en el establecimiento del contenido de la razón práctica (y por lo tanto de la ética y de una buena política). ${ }^{20} \mathrm{El}$ "primero de los primeros principios de la ley natural" (202) no articula, ni siquiera genéricamente, el concepto de un fin universal o bien final de los seres de nuestra naturaleza. ${ }^{21}$ La vigorosa indagación

19 Véase el comentario de Cayetano a la Summa Theologiae, I-II, q. 66, a. 3, ad 3 (Aquino, Tomás de, Opera Omnia [edición Leonina], VI, p. 433). Yo mismo he tratado de mostrar en algunas reflexiones todavía inéditas sobre los pasajes relevantes en el Aquinate cómo pueden y deberían ser sintetizadas: "A Problem about Practical Reasonableness in Aquinas" (presentada, con un comentario de Irwin, en Chapel Hill, North Carolina, en 1998).

20 Irwin muestra bien cómo "un agente virtuoso debe entender (quizá sin formularlo) el tipo de consideraciones que conciernen al teórico" (210).

21 Después de haber citado la parte central de la I-II, q. 94, a. 2, acerca de los primeros principios de la razón práctica, Irwin afirma: "En este pasaje Tomás de Aquino se refiere a su previa discusión sobre el bien último (I-II, qq. 1-5)" (202). Pero yo no veo en la q. 94, a. 2 ninguna referencia, ni siquiera implícita, a esa discusión acerca del "bien último". La conexión que hace la q. 94, 
del Aquinate acerca de ese fin último, al comienzo de la Prima Secundae (indagación guiada tanto por preocupaciones y premisas específicamente teológicas, cuanto por el modelo de la Ética de Aristóteles) producen poco o ningún fruto para una ética filosófica, más allá de la noción paradójica de que existe una imperfecta beatitudo, una "total realización" incompleta, que consiste en vivir de acuerdo con las virtudes. En qué consiste tener esas virtudes, y de qué modo la propia comprensión receptiva puede avanzar desde los primeros principios captados en la sindéresis hasta la distinción entre lo moralmente bueno y malo, y entre elecciones virtuosas y viciosas, queda en las primeras secciones de la Prima Secundae en tanta oscuridad como en Aristóteles en su discusión sobre la eudaimonía en los capítulos I y X de la Ética tras iluminar la virtud de justicia en el capítulo $\mathrm{V}$.

No, el "primero de los primeros principios de la ley natural", que ocupa la misma posición en el pensamiento práctico que el principio de no contradicción en todo el pensamiento, ${ }^{22}$ impone sólo que actuemos hacia algún objetivo inteligible, y los primeros

a. 2, entre bien y propósito no es, desde luego, "ni tautológica, ni trivialmente analítica", pero esto no es porque al afirmar la conexión el Aquinate "sostenga que los agentes racionales, al actuar en razón del bien, buscan alcanzar una estructura racional en sus objetivos" (o al menos él no está aquí haciendo, ni necesita hacer) una afirmación sobre la "estructura racional en sus objetivos", bajo la descripción de un orden racional de objetivos hacia un único objetivo final. El hecho de que qq. 1-5 parezcan argüir que cualquiera que tiene racionalidad no puede por menos que tener un único objetivo final de ese tipo, es importante para el Aquinate, pero no, pienso, para la q. 94, a. 2, ni tampoco para su desarrollo en la estructura de los principios secundarios de la razón práctica, que son la razón (ratio) de las virtudes morales y los principios más generales del derecho positivo. La vinculación afirmada en la q. 94, a. 2, se mueve entre los conceptos de lo deseable (apetecible) y lo perfectivo (aquello que hace mejor y por lo tanto constituye una oportunidad); el estrecho vínculo entre ellos está expuesto con la mayor claridad en la Summa Theologiae en I, q. 5, a. 1 (véase Natural Law and Natural Rights, pp. 78 y 79).

22 Summa Theologiae, I-II, q. 94, a. 2c ("Hoc est ergo primum principium legis, quod bonum est faciendum et prosequendum, et malum vitandum"); Finnis, J., Aquinas, pp. 79, 80, 86 y 87. 
principios sustantivos son imperativos precisamente al y por elegir los tipos de objetivo (fin, bien, valor) que tienen la inteligibilidad requerida; son inteligibles en cuanto que deseables por ser beneficiosos para alguien: vida, matrimonio, conocimiento, amistad, razonabilidad práctica, así como semejanza y armonía (incluso assimilatio) con la fuente trascendente de toda realidad y valor. ${ }^{23}$

Cualquiera que parta de un conocimiento básico de la causa y el efecto y de lo que es posible (e. g., que las preguntas se pueden responder, y que las respuestas unidas resultan ámbitos de conocimiento) puede comprender tanto el contenido como la imperatividad de las proposiciones que escogen y nos imponen seguir estos bienes humanos básicos. Pero no se puede responder en concreto a esa imperatividad sin considerar esos fines tanto en su relación mutua como en relación con lo que puede realizarlos y/o hacerlos efectivos de modo inteligente. Porque no podemos perseguir ningún tipo de fin, por más que sea último o "macro", sin ponerlo en relación con los medios (con algo que promueva o realice y concrete un fin de ese tipo: Summa Theologiae, I-II, q. 12, a. 4). Por lo tanto, todo lo referente al modo en que estos bienes humanos básicos inteligibles son coherentes entre sí y son realizables sensatamente (razonablemente) es asunto de la racionabilidad práctica, es decir, de la prudencia. ${ }^{24}$ No hay una "facul-

23 Aquí ajusto levemente la lista que propone el Aquinate en ST, q. 94, arts. 2 y 3, cambiando "conocimiento de Dios", para acomodar la estrecha relación que él ve entre la deseabilidad del conocimiento de Dios y la deseabilidad de, conociéndolo, ser como él; Summa contra Gentiles, III, c. 25, n. 1; Finnis, J., Aquinas, pp. 308-315.

24 Cuando Philippa Foot se liberó del neo-humeanismo que apunté como fundamental a su pensamiento moral en mi "Reason, Authority and Friendship in Law and Morals", fowett Papers, 1968-1969, ed. B.Y. Khanbhai, R.S. Katz, \& R.A. Pineau (Oxford, Basil Blackwell,1970), pp. 101, 24 (y véase su comentario en la p. 25), y Finnis, J., Fundamentals of Ethics, pp. 28, 29, 62, una parte importante de esa liberación provino de ver el error de sostener, tal como tantos lo han hecho y lo hacen, que "primero llegamos a la teoría de la acción racional, y después tratamos, lo mejor que podemos, de encajar la racionalidad de los actos de justicia y caridad"; "Does Moral Subjectivism Rest on a Mistake?" [su Hart 
tad especial" llamada sindéresis. ${ }^{25}$ En realidad, de un fin a otro de la razón(amiento) práctica, sólo hay el propio entendimiento (intellectus, intelligere) con sus orígenes o raíces o fundamentos en actos no-deductivos de profundización en, de entendimiento de, los datos de la experiencia, y después el esfuerzo y la disciplina del juicio razonable, como es propio de una "persona de buen juicio". "Juicio" 26 es sin duda la expresión inglesa práctica para indicar prudentia, que en sí misma no es más que la prolongación de la propia inteligencia a la conformación (informando y dirigiendo, con la inteligibilidad integral de los bienes básicos) de las propias deliberaciones, juicios, elecciones y a la transformación de las propias elecciones en acciones, y en el cumplimiento posible según las circunstancias propias y de aquellos a quienes beneficia nuestra acción.

Estoy de acuerdo con Irwin (y con Aristóteles y Tomás de Aquino) en que los principios elegidos por una ética filosófica y que informan esa teoría ética y toda teoría política y jurídica dignas de ese nombre, no pueden ser otra cosa que una reflexiva, auto-consciente y convenientemente extensa, versión de la prudencia, de un pensamiento sensato acerca de lo que hay que hacer con la propia vida, incluyendo la vida como ciudadanos.

Lecture de 1994 en Oxford], Oxford Fournal of Legal Studies, 15, 1995, pp. 1-14, en pp. 4 y 5. Acerca del error que Sidgwick denominó y defendió como "el punto de vista ético moderno", véase por ejemplo mis comentarios en Aquinas, 111, sobre las teorías "construidas para exponer la racionalidad y/o primacía natural de la «prudencia» egoísta, y explorar la cuestión de cómo podemos «trazar un puente» entre esa prudencia (de una orilla) y moralidad (en la costa más lejana)". Cfr. Finnis, J., Natural Law and Natural Rights, p. 134.

25 La primera afirmación del Aquinate sobre la sindéresis es que no es una potencia (sino más bien un habitus). ST, I, q. 79, a. 12c; cfr. Irwin, p. 201.

26 "Mis días de inexperiencia. Cuando mi juicio aún estaba verde", Anthony \& Cleopatra, 1.5.607; véase también 1.4.555: “jóvenes, que siendo maduros en conocimiento, empeñan su experiencia en su placer presente, y así se rebelan contra el juicio"; asimismo, 2.2.754, 3.13.2279, y otros lugares incontables en las reflexiones de Shakespeare sobre los caracteres y las acciones. No importa, en definitiva, que Cleopatra esté equivocada, o coqueteando, al decir que ahora es menos inmadura, menos falta de razonabilidad práctica. 
Menciono esto aquí porque la idea de que no se puede hacer bien teoría ético-política sin poseer la virtud moral (e intelectual) de la razonabilidad práctica puede parecer arrogante, pero en realidad es un reconocimiento de que en este tipo de teorización se tiene una vulnerabilidad especial e inevitable al error teórico, concretamente al que es consecuencia de algún lamentable defecto en nuestro carácter, que supone cierta falta de prudentia. Por supuesto, se puede ser, para decirlo "académicamente", partidario de buscar el propio camino en el marco de un sistema ético que se acepta en proposiciones ya articuladas por otros, ya sea por un magister individual o por una comunidad, "escuela" o tradición, y más aún si se trata de un sistema jurídico (como nosotros hoy podríamos ser partidarios, por ejemplo, de la esclavitud tal como se daba en el derecho romano. Esto no necesita una razonabilidad práctica muy desarrollada, ni prudentia ni otras virtudes. Pero no se trata de una teoría, propiamente hablando).

No obstante, de aquí no se sigue que todos los errores o debilidades que se cometen al teorizar deban ser atribuidos a las propias imperfecciones morales. Los descuidos y errores en el juicio teórico pueden estar motivados por no reflexionar con precisión en nuestras deliberaciones y disposiciones, y/o no razonar correcta y enérgicamente a partir de esas reflexiones. La explicación de la ética propuesta en Natural Law and Natural Rights se equivoca al identificar lo que valida y unifica la inteligibilidad de los ocho o nueve principios sobre los cuales versa su capítulo sobre los "requerimientos metodológicos de la razonabilidad práctica". Debería haber explicado estos principios proto-éticos como especificaciones del principio maestro de la moral, según el cual debemos permanecer abiertos, en todo nuestro deliberar y querer, a la realización completa (que ni es la propia ni indiferente a la propia, sino que radica en la realización de todas las personas humanas en todas sus comunidades). Estas especificaciones aportan algo verdaderamente decisivo que "decirnos a nosotros mismos" (tal como lo dice Korsgaard) frente a las motivaciones emocionales que pueden desviarnos de (en la medida 
en que son distintas de las que nos mantienen en ello) responder con razonabilidad integral a las directivas de las razones básicas. $\mathrm{Y}$ de este modo nos movemos a partir de la comprensión, en sí misma pre-moral, ${ }^{27}$ de los bienes humanos básicos, las razones prácticas básicas, en pos de distinciones y razones morales (desde, por ejemplo, bienes como "vida-saludable", o integridad racional-emocional, con sus correlativos males o daños corporales o psicosomática, falta de armonía y sufrimiento, hasta la distinción moral entre la crueldad y la acción benéfica de infligir un sufrimiento como un efecto colateral de, por ejemplo, curar o auxiliar).

\section{$\mathrm{V}$}

Este trabajo se mantiene en los fundamentos y no va más adelante, ni hacia los principios intermedios que estructuran el pensamiento específicamente moral (y en realidad el jurídico) ni hacia dialécticas de método ético, tales como utilitarismo, consecuencialismo o proporcionalismo y sus contrincantes teórico-jurídicos. ${ }^{28}$ El tema del trabajo son los primeros principios prácticos en su contenido progresivamente desvelado. Un motivo para mantenerse aquí es subrayar la unidad de la propia razón. Si bien la razón

27 "Pre-moral" no significa "no-moral”; véase Aquinas, 87: "El sentido moral de «debe, entendido de modo crítico, no meramente convencional, se alcanza... cuando se sigue la relación del (absolutamente) primer principio práctico con todos los otros primeros principios, conforme a una razonabilidad que no es restringida ni desviada por ningún factor subrracional, como puede ser una emoción distractiva. En ese sentido, el «debe» de los primeros principios es «incipientemente» o «virtualmente», pero todavía no actualmente, moral en su normatividad o carácter directivo".

28 Véase Natural Law and Natural Rights, pp. 111-124; Fundamentals of Ethics, pp. 80-135; Nuclear Deterrence, Morality and Realism, Oxford, Clarendon Press, 1987, pp. 177-272; Moral Absolutes, pp. 13-83; "Commensuration and Public Reason", in Incommensurability, Incomparability, and Practical Reason, ed. Ruth Chang, Cambridge-Mass., Harvard University Press, 1997, pp. 215-233, 285-289. 
encaminada a la deliberación y a la elección tiene sus primeros principios, verdaderamente primeros y no deducibles, la razón teórica o especulativa y la razón práctica no son de ningún modo dos potencias diferentes. Cuando pensamos seriamente acerca de qué sería bueno hacer, alcanzar, o llegar a ser, nos basamos en lo que creemos acerca de lo que puede ser, es, ha sido, o es probable. Y comprender verdades básicas, tales como que "el conocimiento es bueno y deseable y ha de ser valorado y buscado" (accesible aun para aquellos que no lo hacen), presupone una conciencia (podríamos decir "teorética") de la posibilidad (accesibilidad) de superar la ignorancia, una conciencia que es complementada con el nuevo conocimiento "práctico", original y no derivado lógicamente (no-deducido), articulado en esa misma proposición práctica. Igualmente, cuando pensamos seriamente acerca de qué índole de ser somos los seres humanos, nos basamos en ese conjunto de principios prácticos originales y primarios que son no sólo la fuente (principium) de la normatividad ${ }^{29}$ articulada en el pensamiento jurídico ${ }^{30}$ y moral, sino también una fuente de nuestro conocimiento de la naturaleza humana. Porque, repito, conocemos la naturaleza de una realidad dinámica como la nuestra conociendo las capacidades de ese tipo de ser que somos, y a su vez conocemos las capacidades conociendo las actividades de las cuales esos seres son capaces, y sólo comprendemos esas actividades conociendo su objetivo - que es precisamente lo que encontramos al identificar cada una de las formas básicas de bien humano-.

29 Hay otras fuentes de normatividad, lógicas, técnicas o naturales. Pero en tanto el pensamiento propio en lógica, tecnología y arte, así como en ciencias naturales y en el ámbito ético y jurídico, es una acción sujeta a las propias elecciones, la dirección real del pensamiento y la argumentación depende siempre, al menos en parte, de la normatividad práctica que implica la bondad y la prosecución del valor propias del conocimiento.

30 Por supuesto, existe mucho pensamiento jurídico que, de hecho, meramente imita sin participar en el reconocimiento de la normatividad moral que da su mejor sentido a la existencia del derecho; pero este pensamiento jurídico no es central, por más frecuente que sea. 
"Identificar" es, no obstante, un término poco adecuado. De lo que estamos hablando es de un entender cada uno de esos aspectos o modos deseables de ser persona o una comunidad humanas. Tal como vengo diciendo, ese entender es igualmente una percepción, es ser consciente, de la normatividad que, una vez desarrollados su contenido y su fuerza, llamamos moral; es ser consciente tanto del contenido como de la fuerza racional (normatividad, imperatividad) de las proposiciones morales. Lo más específico y propio de las normas morales no será más que una especificación de lo que estaba (está) genéricamente contenido como imperativo en los principios que expresan las formas básicas de la oportunidad/perfección humana. Por lo tanto: lo que estos principios básicos contienen, lo que son verdaderamente estas formas básicas de bienestar humano, ha de ser indagado con celo y cuidado (con esfuerzo) y con todos los recursos de la reflexión, incluyendo aquello que vagamente denominamos ficción (por ejemplo, El rey Lear).

Lo que llamamos voluntad es esencialmente nuestra capacidad de respuesta a la propia comprensión de esas oportunidades (si la enseñanza de Hume acerca de la incapacidad de la razón para motivar fue el resultado de su equivocada comprensión del comprender, o más bien de su equivocada comprensión de los múltiples estratos de los apetitos humanos, poco interesa: esa enseñanza es completamente equivocada). ${ }^{31}$ Cuando tratamos de expandir nuestra comprensión de las formas básicas de oportunidad que se nos abren, respondemos (con ese tipo de interés genérico o actitud proactiva que el Aquinate llama voluntas simplex) a la bondad inteligible de cualquier tipo de bien que sea en ese momento el objeto de nuestra indagación, pero también respondemos con algo más concreto y cercano a la elección, esto es, con

31 A las críticas de Korsgaard, resumidas en el apartado III, hay que agregar, por ejemplo, George, R. P., "A Defense of the New Natural Law Theory", en In Defense of Natural Law, Oxford, Oxford University Press, 1999, pp. 17-30; Boyle, J., "Reasons for Actions: Evaluative Cognitions that Underlie Motivations", American Fournal of Furisprudence, 46, 2001, pp. 177-197. 
la intención, hacia el bien inteligible del conocimiento, y hacia el bonum rationis, el bien del influjo motivador que proviene de la razón y su normatividad en nuestra propia vida, más existencial que meramente proposicional (en nuestro deliberar, elegir y hacer). ${ }^{32}$

En los últimos veinticinco años, varios de los que estamos comprometidos en tareas de reflexión práctica (Natural Law \& Natural Rights es una manifestación), hemos ensayado diferentes explicaciones de los bienes humanos básicos. Por ejemplo, el matrimonio no fue identificado propiamente en NLNR, donde la vida, la transmisión de la vida y la amistad quedaron en una posición incierta. ${ }^{33}$ Creo que un buen ejemplo es la reflexión sobre la complementariedad de los dos sexos, y acerca del modo en que, en los actos maritales, la pareja puede actualizar, expresar y tener experiencia de su compromiso con el matrimonio como forma de amistad orientada y apropiada a la procreación. ${ }^{34}$ Después está ese bien que podemos llamar armonía entre las personas, o amistad, sociabilidad, o incluso justicia. La igualdad radical (fundacional) entre las personas que es en realidad su verdadero núcleo, se puede entender al reflexionar sobre situaciones extremas, como, por ejemplo, si una represalia contra los habitantes de una ciudad enemiga, o un ataque bélico estratégico contra los habitantes de una ciudad o región, o la producción de seres hu-

32 Sobre el bonum rationis, ampliamente descuidado en las explicaciones e intentos de recreación de la teoría moral del Aquinate, aun cuando es el bien al cual la prudentia es la respuesta adecuada, véase Summa Theologiae, I-II, q. 94, aa. 3 \& 4; asimismo, q. 91, a. 2c, q. 93, a. 6c; Aquinas, pp. 83-85, 98 y 99.

33 Véase, Natural Law and Natural Rights, pp. 86 y 87. Los editores y traductores de las consideraciones del Aquinate acerca de los principios básicos en la Summa Theologiae, I-II, q. 94, a. 2c, han mostrado una falla similar en la comprensión de este asunto: véase, Finnis, J., Aquinas, pp. 82, 97 y 98.

34 Véase, por ejemplo, Grisez, G., The Way of the Lord Jesus, vol. 3: Living a Chistian Life, Quincy-Illinois, Franciscan Press, 1993, cap. 9, especialmente la sección E; Finnis, J., "The Good of Marriage and the Morality of Sexual Relations: Some Philosophical and Historical Observations", American fournal of Furisprudence, 42, 1997, pp. 97-134. En cierta medida se trata de un redescubrimiento por parte de la filosofía de algo ampliamente alcanzado en otros dominios del pensamiento. 
manos a través de la manipulación técnica, son oportunidades o meras tentaciones.

El bien que tenemos quizá mayor posibilidad de considerar de cerca es el de la vida humana misma. Desde su comienzo a su fin, es nada menos que la existencia real de la persona, del ser humano. El Aquinate, precisamente cuando presenta su lista de los bienes humanos básicos, completa, aunque no exhaustiva, dice que este bien es, como la existencia, uno que compartimos con todas las otras creaturas, cualesquiera que éstas sean. ${ }^{35}$ Si bien esto es verdadero, sería muy engañoso si impide que percibamos las grandes diferencias entre la existencia de una molécula (o un lago) de agua, la vida de una zanahoria, la vida de un gato y la vida de un ser humano. Porque la vida humana es la existencia de un ente con las capacidades radicales (reales en su orientación a la acción aun cuando se encuentren impedidas en su actuación por inmadurez, sueño, enfermedad o vejez) para vivir con santidad, heroísmo, vergüenza o culpa.

Pero estas son categorías morales (si no también jurídicas) del carácter humano, por lo que restringiré mi exposición de este punto a categorías más fundamentales, tales como significado, verdad y libertad. Nuestra naturaleza en cuanto creaturas humanas, la matriz de las capacidades radicales que todos tenemos desde el comienzo, viene ejemplificada por cómo hacemos cosas con palabras. Ciertos sonidos o señales, puramente físicos, aun cuando permanezcan en la imaginación y la memoria como estados cerebrales, transmiten, a través de cierta forma de corporización, tanto comprensión como intención (voluntad de comunicar esto y no aquello o no esto $)^{36}$ entre personas completamente separadas en todas las dimensiones físicas. Esta comunicación muestra, de modo análogo a como el efecto muestra la causa,

35 ST, I-II, q. 94, a. 2c.

36 Este sentido dual de "significado" (meaning) es una de las realidades sutilmente evocadas en The Tempest, 1.2.496-499: "When thou didst not, savage / Know thine owne meaning; but wouldst gabble like / A thing most brutish, I endow'd thy purposes / With words that made them known". 
cómo el ser, constitución y existencia de sus autores humanos, su materialidad o corporeidad (física, química, biológica o psicosomática) está unida con algo tan inmaterial como un significado que se puede compartir a través del espacio o del tiempo (o en la mesa del comedor o en la sala de un tribunal). Según argumenta el Aquinate, esta unidad se ve al hablar del alma como la forma y act(ualización) del cuerpo, de modo que puede decirse que "contiene" al cuerpo y es su misma base. ${ }^{37}$ Así llegamos al fundamento metafísico de la igualdad humana, que implica la no-igualdad de todo el resto de las creaturas de las que tenemos experiencia; de todas ellas puede decirse no que son no-humanas, sino sub-humanas, o carentes de la dignidad de los humanos porque les falta nuestra capacidad radical fundacional. ${ }^{38}$

En el pensamiento práctico, la metafísica de la persona humana (que acabo de exponer esquemáticamente) normalmente queda fuera del foco de atención. En su lugar queda, en primer lugar, la idea, intrínseca a la captación inicial de los primeros principios prácticos, según la cual bienes básicos, como el conocimiento, la vida y la amistad, son buenos no sólo para mí o para ti, sino para "cualquiera", y en segundo lugar, la conciencia o asunción de que nuestras elecciones, y por lo tanto nuestras acciones, importan, y de que somos responsables en los cuatro sentidos que distinguió Hart: ${ }^{39}$ causamos efectos, tenemos al menos la

37 Véase Finnis, J., Aquinas, pp. 177-179; “«The Thing I am»: Personal Identity in Aquinas and Shakespeare", Social Philosophy and Policy, 22, 2005, pp. 250-282, especialmente pp. 253-257; también en Personal Identity, ed. Ellen Frankel Paul et al., Cambridge-New York, Cambridge University Press, 2005, pp. 250-280, especialmente pp. 253-257.

38 Sobre la "capacidad radical", véase mis "A Philosophical Case Against Euthanasia", "The Fragile Case for Euthanasia: a Reply to John Harris", y "Misunderstanding the Case Against Euthanasia: Response to Harris's first Reply", en Euthanasia: Ethical, Legal and Clinical Perspectives, ed. John Keown, Cambridge, Cambridge University Press, 1995, pp. 23-35, 46-55, 62-71, especialmente pp. 30, 31, 68-70.

39 Hart, H. L. A., Punishment and Responsibility, Oxford, Oxford University Press, 1968, capítulo 10. 
capacidad de preocuparnos y de elegir, podemos tener roles y deberes de cuidado y dirección y, consecuentemente, responsabilidad por la que ser elogiados o reprobados, por mérito o culpa, lo que no tiene sentido salvo que nuestras elecciones libres no corregidas permanezcan en nosotros como la dimensión intransitiva, auto-conformadora, constitutiva de identidad, de las acciones $\mathrm{u}$ omisiones elegidas.

Nuestro interés en esa atribución de responsabilidad múltiplemente fundada implica una intuición práctica-y-teórica de que nuestra existencia es la de entes que hoy importan debido a nuestras identidades subsistentes e individuales, cada una con un pasado, así como con un futuro. Esta trascendencia de lo material, tanto en los beneficios que prevemos cuanto en las personas que sabemos abiertas a recibirlos, es parte de lo que justifica el pensamiento de que cada uno de nosotros importa; importa en vida o muerte, en salud o enfermedad, en conocimiento o ignorancia, en razonabilidad o irrazonabilidad, en amistad o egoísmo. Es parte de lo que justificaba Elizabeth Anscombe al referirse, filosóficamente, al "valor místico del ser humano". ${ }^{40} \mathrm{~A}$ pesar de que ella trataba la palabra "mística" del mismo modo que trataba la expresión de Aristóteles acerca del florecer del rostro de los jóvenes para explicar la relación entre el placer y el objetivo de una elección razonable (ella lo llamaba "balbuceo"), creo que es una palabra más adecuada para expresar el valor de la existencia de cada ser humano que la palabra "absoluto", que alguien podría reconocer en la exposición de Korsgaard.

Necesitamos una conciencia de ese tipo del valor de lo humano si tenemos que dar sentido a la fuerza normativa, al carácter imperativo de los principios de la razón práctica, carácter que tienen cuando se toman, no uno tras otro, separadamente de los demás, sino en su imperatividad integral, bajo la imperatividad regulativa del bien de la racionalidad práctica misma (es

40 Human Life, Action and Ethics: Essays by G.E.M. Anscombe (St. Andrews Studies in Philosophy \& Public Affairs), ed. Mary Geach and Luke Gormally, London, Reutledge, 2005, p. 260. 
decir, cuando se toma como moralmente normativa). Algunas veces la muerte de alguien que conocemos refuerza en nosotros esa conciencia. Shakespeare, que representa incomparablemente la actualidad, la total vitalidad de las vidas humanas, pero cuyas intenciones eran al mismo tiempo más filosóficas de lo que a menudo se reconoce, tomó la muerte real de algunos individuos como ocasión para mostrar (¡entre otras cosas!) la dependencia entre la razón práctica y su imperatividad y una conciencia receptiva del valor que los seres humanos tienen y que pueden aumentar o disminuir por su receptividad hacia él. En un poema enigmático y sin paralelo, publicado originalmente en 1601 y conocido comúnmente como El fénix y la tórtola (Phoenix and Turtle), inmortaliza, como Patrick Martin y yo hemos tratado de mostrar, ${ }^{41}$ el matrimonio y muerte de una joven viuda poco después de su ejecución pública por razones religiosas en los últimos días de febrero de 1601; celebra, por decirlo así, no sólo la unión entre esposa y esposo (fénix y tórtola) a lo largo de años de separación a causa del exilio del esposo por causas religiosas, sino también su fidelidad a través de los años después de su muerte. La palabra utilizada en el poema para plasmar constancia y fidelidad al compromiso es, tal como era entonces el uso común de las palabras, "verdadero" y "verdad". A pesar de la extrema abstracción de su "himno" central, ya su riguroso acomodamiento a las formalidades del razonamiento y de la religión, lo que el poema expresa principalmente es la pena, que parece ser sin duda la del autor mismo, y una especie de admiración ante la costosa y activa lealtad de los esposos entre sí (así como hacia lo que ellos defienden como lo más querido, conservado en común, y por causa de lo cual cada uno murió en soledad). La cercanía y constancia en el amor de esta pareja, especialmente mientras estuvieron separados por el exilio, es celebrada, a lo largo de siete estrofas, a través de una serie de paradojas virtuosas, cuasi-matemáticas, cuasi-metafísicas, que culminan en la estructura causa-y-efecto, evidencia-

41 "Shakespeare Intercession for Love's Martyr", Times Litterary Supplement, 18.05.2003, pp. 12-14; véase, asimismo, "The Thing I Am”, pp. 267-270. 
e-inferencia, antecedente-y-consecuente, que se introduce junto con el cuasi-personal y último sujeto del poema, la razón misma:

Reason, in itself confounded, Saw Division grow together, To themselves yet either neither,

Simple were so well compounded. That it cried, how true a twaine, Seemeth this concordant one,

Love hath Reason, Reason none,

If what parts, can so remaine. ${ }^{42}$

"El amor tiene razón" se presenta aquí con el mayor cuidado como expresión del propio juicio autocomprensivo de la razón. Cualquiera que acepte una posición como la que he venido sosteniendo o re-presentando en este trabajo, querrá tomar esta

42 Líneas 41-48. El himno del poema comienza en la línea 22 con "Love and constancy is dead", y su lamento ("Threnos") alcanzará su conclusión no del todo final en la línea 64 con "Truth and beauty buried be". Ese lamento comienza en la línea 53 con "Beauty, truth and rarity, / Grace in all simplicity, / Here enclos'd cinders lie", y termina (líneas 65-68) "To this urn let those repair / That are either true or fair: / For these dead birds sigh a prayer" - afirmando así que la muerte de esta pareja ejemplar no es ni el olvido ni la exterminación - Nota del traductor: no he traducido por mí mismo el verso de Shakespeare porque no me considero con la capacidad necesaria para hacerlo; como dijera hace ya varios años mi padre, quien tradujo a Píndaro, Gerard de Nerval, Alfred de Musset, Charles Maurras y varios otros poetas, la traducción de la poesía requiere de una habilidad y un entrenamiento especial, y no es suficiente con el buen conocimiento de la lengua (Massini Correas, C., "Confesión de un traductor", Revista de Estudios Franceses, Mendoza, Facultad de Filosofía y Letras, núms. 4 y 5, 1949, pp. 177-195). Por otra parte, algunas de las traducciones al español de este verso que he podido consultar, en especial las de Luis Astrana Marín y Ramón García González, han sacrificado ostensiblemente la literalidad y el contenido filosófico del poema en homenaje a la rima y a la métrica, con un resultado claramente decepcionante. Transcribo aquí entonces la traducción de Edison Simons de los versos citados, que me parece la más fiel al texto shakespeariano: "La razón, en sí misma confundida, / Vio junta crecer la división, / Ante sí mismos ni uno ni otro empero / Tan bien compuestos estaban los simples, / Que ella gritó: ¡cuán verdadero par / Parece este uno concordante! / Amor tiene razón, razón ninguna, / Si así pueden quedar las partes". En Shakespeare, W., El tórtolo y fénix, ed. Nicole d'Amonville, Barcelona, Herder, 1997, p. 107. 
afirmación en un sentido que corresponda no al humeano-weberiano "el deseo crea la razón" y "confiere valor a sus objetos", ni tampoco al pascaliano "el corazón tiene sus razones, que la razón no conoce". ¿No podría ser que este "el amor tiene Razón” del poeta fuera compatible con (o quizá incluso confirmara) la proposición de que el amor de las personas, de cada una hacia su propio bien, contiene las razones que señalan los primeros principios prácticos, los bienes humanos hacia los que esos principios nos encaminan, siendo cada uno de esos bienes un aspecto del valor (en privación o realización) de cada ser humano?

Los primeros principios de la razón práctica son, por así decirlo, transparentes para las personas que pueden realizarse según la dirección en que estos principios nos encaminan; tan transparentes que, en verdad, respondemos a través de esas personas cuando respondemos a la llamada de esas razones. Un amor de ese tipo va desde el omniabarcante "Ama a tu prójimo como a ti mismo", hasta un compromiso particular con otro ${ }^{43}$ (por ejemplo, el único compromiso exclusivo que es el amor marital) y está en la esencia de toda la normatividad práctica que llamamos moral y, en ciertos casos, jurídica. Y para reincidentes como nosotros, las relativamente pocas personas de virtud heroica pueden ser un recordatorio, inspirador más que deprimente, de que si no es por nuestra propia respuesta (nuestro "amor" y "voluntad") a lo que esas razones exigen de nosotros, la capacidad racional podría no ser y no será para cada uno de nosotros nada más que

43 Véase Finnis, J., Aquinas, p. 127: “«Debemos amar a nuestros prójimos». Pero amar a una persona voluntariamente (no sólo emocionalmente) es querer el bien de esa persona. Por tanto, amar a nuestro prójimo es querer su propio bien —y no solo éste o aquel bien, sino el bien, de algún modo, integral—; y nada inconsistente con el todo armonioso que incluye el propio bien (del mismo modo integrado en sí mismo y con los bienes de otros). Así, el principio del amor al prójimo tiende a unificar los propios objetivos. Más aún, el amor al prójimo requerido por este principio no necesita ser una amistad concreta $(\mathrm{FN}$ : El amor involucrado en una amistad concreta (amor amicitiae) ha de tener en su núcleo, no obstante, la propia voluntad en cuanto amigo de tratar al amigo como uno se trata a sí mismo - amans se habet ad amatum, in amore amicitiae, ut ad seipsum - :ST, II-II, q. 28, a. 1, ad 2)". 
lo que Hume pretendía que debía ser para todos: una esclava de las pasiones, que por lo tanto es, no da ni tiene "ninguna razón". Si el poeta, que fue un maestro de juicio (aunque buscara no parecerlo), y cuya capacidad artística alcanza su fuerza más profunda en representaciones de reconciliación y amistad, niega que el más alto y el más profundo imperium pertenezcan al ciego deseo o aversión, entonces tenemos un testigo elocuente o un abogado (aunque no precisamente un argumento); pero que esa interpretación sea adecuada o no es una quaestio disputabilis para otro día. En cada caso puede haber quien encuentre más persuasiva la resonancia de los principios argumentados en la experiencia viva, en las aspiraciones y esfuerzos, y no me refiero solamente a los pobres provincianos de tierra adentro.

\section{Postscriptum}

\section{A. Inclinaciones naturales y primeros principios prácticos}

Patrick Lee me pide que sea más explícito o preciso acerca de lo que he llamado la dependencia de la razón práctica y de su imperatividad de una conciencia receptiva al valor que tienen los seres humanos y que puede incrementar o disminuir a través de su propia receptividad a ese valor. Esto está vinculado (desde mi punto de vista) con la cuestión de si Lee está en lo correcto al decir que, de acuerdo con el Aquinate, nuestras intuiciones de los bienes humanos, las intuiciones que se articulan en los primeros principios prácticos, se orientan "hacia nuestras inclinaciones naturales", inclinaciones que son "datos para la percepción práctica”. Ése no es el modo en que leo al Aquinate, pero tampoco, y eso es más importante, creo que sea el modo en que las cosas (hasta donde puedo ver) realmente son. En realidad, pienso que la intuición práctica, por ejemplo, de que el conocimiento es bueno y digno de ser perseguido, toma como punto de partida (al que la intuición agregará algo nuevo) la conciencia, no sólo del 
impulso (inclinación) a preguntar y de la experiencia de satisfacción cuando se responde a la pregunta, sino también la intuición "teorética" de que es posible el conocimiento. A la experiencia de una pregunta que obtiene una respuesta, de otra pregunta que también obtiene una respuesta, y así sucesivamente, esta intuición no-práctica agrega el original (nuevo) entendimiento de que hay un horizonte completo de posibilidades (que se puede llamar verdad y conocimiento) del cual las respuestas particulares a preguntas particulares son sólo concreciones. Sólo entonces la intuición práctica agrega el entendimiento práctico posterior de que ese campo de posibilidades es también un campo de oportunidades, beneficios, perfecciones, etcétera. Cuando se sigue esta segunda intuición práctica, al elegir comprometerse con el estudio, la reflexión, la investigación, y así sucesivamente, la propia comprensión original, tanto de las posibilidades del conocimiento como de su valor, es ampliada y profundizada en gran medida.

Pienso que este reforzamiento mutuo de las intuiciones teorética y práctica es penetrante. A través de él, la inicialmente infantil intuición de la verdad práctica que ve las oportunidades como oportunidades para mí y para cualquiera como yo, o el ser amigo, como el valorar y desear el bien de otro u otros por su propio bien, resulta reforzado por el conocimiento de mi propia capacidad y la de otros de hacer los esfuerzos, asumir los compromisos, estar disponible para los demás, etcétera, propios de la amistad, pero también de desarrollar racionalizaciones retorcidas y evasiones traicioneras, y así sucesivamente. A través de esta profundización sobreviene el entendimiento práctico del valor de la persona para la cual o por la cual esos actos de voluntad y de comunicación son posibles.

B. Razón y amor

El comentario de Terence Irwin en nuestra conferencia dio lugar a algunas cuestiones inquisitivas acerca de la amistad y la 
realización o eudaimonía. Él recogió mi explicación de "El amor tiene razón, la razón ninguna" y dijo: "Entiendo que Finnis quiere decir que el amor a las personas por su propio bien ayuda a explicar de qué modo los hechos acerca de la realización humana constituyen razones que guían nuestra acción, y de ese modo ayudan a explicar la normatividad". Y más tarde dijo que "tal y como yo entiendo la visión shakesperiana de Finnis, él asigna una suerte de prioridad al amor en la generación de las razones".

Pero quiero mantener, y sugiero que el poema mantiene la prioridad de la intuición y de la comprensión de los bienes por encima de toda respuesta de la voluntad, incluyendo el tipo de respuesta totalizante propio de la amistad o del amor amicitiae.

La razón que es presentada en el poema es al principio la razón teorética, la que queda confundida por las paradojas de la unidad y la diferencia, cuasi-paradojas conceptuales como que el uno no es un número y así sucesivamente (y también queda desconcertada por la unidad de la amistad, una unidad que es, pienso, aprehendida no demasiado bien por la noción aristotélica del amigo como "otro yo", como por la también noción aristotélica de que en la amistad está en juego un verdadero bien común no reducible a mi bien o tu bien, y completamente ajena a una palabra o frase como "auto-interés".

Y finalmente, lo que la razón encuentra desconcertante es la constancia de la pareja del poema en su compromiso con el otro y con el bien de la verdad que cada uno está buscando más allá de ellos mismos. Lo que asombra a la razón en el poema es (tal y como dice) que su unidad pueda sobrevivir a lo que los separó (tal como el poema no dice explícitamente, pero al descifrarlo sus lectores pueden saberlo: el exilio, la pobreza y finalmente la muerte).

Por ello entiendo que el poema dice no que el amor proporciona motivos desconocidos para la razón, motivos que actúan en lugar de la razón, sino más bien (i) que el amor ejemplificado en la literalmente ejemplar pareja tiene las razones verdaderas (completamente cognoscibles por la razón) que vienen dadas por 
el valor de las personas involucradas, su verdadera capacidad de ser amados, pero (ii) que para vivir de acuerdo a esto hace falta más que la inteligibilidad de los bienes amables concretados en estas personas amables; hace falta la respuesta incondicional de estas personas, y (iii) que observar por ejemplo esa respuesta devota, constante, "verdadera", nos habilita para profundizar y reforzar el propio entendimiento de los bienes del conocimiento, la amistad, y la razonabilidad práctica, y así también el propio entendimiento del bien/valor de las personas cuyas vidas concretan y ejemplifican esos bienes de modo tan asombroso. El amor tiene razones, pero podrían quedarse en "no razón" si se mantuvieran como meras inteligibilidades sostenidas por la razón, y no se encarnaran, más allá de la fungibilidad de bienes que pueden ser y son capaces de concreción en incontables personas, en el compromiso a esta persona particular (algo parecido a este problema surge en el patriotismo y en otras formas de lealtad). 


\section{DEREGHO NATURAL Y RAZONAMIENTO JURÍDICO*}

El razonamiento moral, el razonamiento jurídico y sus interrelaciones no pueden ser comprendidos reflexivamente sin atender a dos causas diferentes de ambigüedad. Estas causas son, en cada caso, bien conocidas: 1) la distinción entre las razones y los sentimientos, y 2) la distinción entre la acción (formación de la propia existencia por medio de las propias elecciones) y el hacer (ejercicio de la técnica por medio de la actividad sobre cierta forma de objeto o método cultural). Pero esas distinciones no son bien comprendidas en general y las trampas que ellas establecen para el análisis de la moralidad y la adjudicación son generalmente descuidadas.

Nosotros somos animales, pero inteligentes. Nuestras acciones tienen todas una motivación emocional; involucran nuestros sentimientos, nuestra imaginación y otros aspectos de nuestra corporeidad, y pueden ser observadas íntegramente (aunque sea en algunos casos por introspección) como partes del comportamiento. Pero las acciones, racionalmente motivadas, tienen también una motivación inteligente - buscan realizar (proteger, promover) un bien inteligible-.

Así, nuestros propósitos, los estados de cosas que típicamente buscamos realizar, tienen un doble aspecto: la meta que imaginamos y que compromete nuestros sentimientos y el beneficio inteligible que apela a nuestra racionalidad por la promesa de realizar, ya sea inmediatamente o instrumentalmente, algún bien

* Traducción de Carlos I. Massini-Correas. Publicado originalmente en Persona y Derecho, Pamplona, núm. 33, 1995. 
humano básico. Mientras que algunos de los propósitos con que empleamos la inteligencia para perseguir algo pueden ser motivados, en su esencia, solamente por el sentimiento, otros propósitos están motivados en su esencia por una comprensión de un bien humano básico. El modo de hablar en que la "razón" se refiere a los propósitos, "la razón por la que él hizo eso", equivalente a su "propósito de hacer eso", falla al establecer la distinción. Pero ninguno de los términos relacionados —"propósito", "meta", "intención" - está libre de la misma ambigüedad. Por ello, especifico que cuando hablo de "razones" en este capítulo me refiero (excepto cuando discuto las razones técnicas) a las razones que dan fundamento a la acción inteligente, motivada en esencia por un bien humano básico (más precisamente por el beneficio inteligible prometido por la realización de un bien básico). ${ }^{1}$

Una descripción de las razones básicas para la acción no debería ser racionalista. El florecimiento humano no debe estar referido solamente en términos de ejercer capacidades para razonar. Como los animales, somos substancias orgánicas, parte de cuyo bienestar es la vida corporal, mantenida con salud, el vigor y la seguridad, y transmitida a nuevos seres humanos. Considerar a la vida humana como una razón básica para la acción, es comprenderla como un bien, en el que infinitos seres pueden participar de muchas maneras, yendo más allá de cualquier meta o propósito que cualquiera pudiera visualizar y perseguir, pero dando sentido a muchos propósitos y proporcionando apoyo racional a muchas e indefinidas metas. ${ }^{2}$

Este sentido de razón (básica) para la acción es válido para los demás bienes humanos básicos: el conocimiento de la realidad

1 Para el uso que aquí hago de las palabras "intención”, "meta", "sentimiento", "beneficio", "motivados" y "bien humano básico", véase Grisez, Germaine et al., "Practical Principles, Moral Truth and Ultimate Ends", American Journal of Furisprudence, 32, 1987, 99-110.

2 Véase Finnis, John et al., Nuclear Deterrence, Oxford, Oxford University Press, 1987, 274-8; Finnis, John, Natural Law and Natural Rights, Oxford, Clarendon Press, 1980, 84-5, 100. 
(incluyendo su apreciación estética); la excelencia en el trabajo y el juego, donde se transforman las realidades naturales para expresar significados y servir a propósitos; la armonía entre los individuos y los grupos de personas (paz, buena vecindad y amistad); la armonía entre los propios sentimientos y los propios juicios y elecciones (paz interior); la armonía entre las propias elecciones y juicios y el comportamiento (la paz de la conciencia y la autenticidad, en el sentido de correspondencia entre uno mismo y su expresión) y la armonía entre uno mismo y las más amplias expresiones de la realidad, incluyendo la realidad constituida por la dependencia del mundo de una fuente de significado y valor, más que humana.

Tal afirmación de los bienes humanos básicos involucra una descripción de la naturaleza humana. ${ }^{3}$ Pero no presupone esa descripción. No es una tentativa de deducir las razones para la acción de algunas concepciones teóricas preexistentes de la naturaleza humana. Tales tentativas desafiarían vanamente la verdad lógica (bien respetada por los antiguos) ${ }^{4}$ de que el "debe" no puede ser deducido del "es": la conclusión de un silogismo no puede contener lo que no está en sus premisas. Más bien, una completa relación de la naturaleza humana sólo puede ser elaborada por alguien que comprende prácticamente los bienes humanos, es decir, como razones para la elección y la acción, como razones que dan completo sentido a los sentimientos y espontaneidades subyacentes. Una descripción del razonamiento práctico puede ser llamada teoría de la "ley natural" porque los primeros princi-

3 Véase Finnis, John, Fundamentals of Ethics, Oxford, Oxford University Press, 2983, 20-2; Finnis, "Natural Inclinations and Natural Rights...”, en L. Elders y K. Hedwing (eds.), Lex et Libertas (Studi Tomistici, 30, Librería Editrice Vaticana, 1987), 43-49.

4 Así, el principal tratado de Aristóteles sobre la naturaleza humana es su Ethica, que es una tentativa de identificar el bien humano y es, de acuerdo con su autor y desde el principio hasta el fin, un esfuerzo de comprensión práctica en oposición a la teórica (véase, por ejemplo, Nicomachean Ethics, 1, 1, 1094 a 26 - b 12, con el comentario del Aquinate); Finnis, Fundamentals of Ethics, 24. La "ética" de Aristóteles no está derivada de ningún tratado anterior sobre la naturaleza humana, ni siquiera de su De Anima. 
pios del razonamiento práctico son aquellas razones básicas que identifican a los bienes humanos básicos como razones últimas para la elección y la acción; razones para la acción que concretarán y expresarán la naturaleza humana, precisamente porque participan en estos bienes, es decir, concretando (actualizando y realizando) aquellos aspectos últimos del desarrollo humano. ${ }^{5}$

En la medida en que el razonamiento jurídico deriva y participa en la razonabilidad práctica, una teoría completa del razonamiento jurídico debe diferenciarse de algunas teorías corrientes hoy en día. En el núcleo de los "Critical Legal Studies", por ejemplo, hay una negación de la existencia de cualquier bien humano objetivo. De las cuatro razones (todas malas) que Roberto Unger ofrece para negar que haya bienes humanos objetivos, creo que el argumento más cercano a su núcleo es que al afirmar que existen esos bienes "se niega toda significación a una elección que no sea la pasiva aceptación o rechazo de verdades independientes y no atiende la significación de la elección como expresión de la personalidad". 6

Pero, en realidad, es la diversidad de los bienes humanos $r a^{-}$ cionalmente atrayentes lo que hace la libre elección a la vez posible y frecuentemente necesaria. Como cualquier otro término que concierne a la actividad humana, "elección" está afectado, en el lenguaje usual, por ambigüedades originadas particularmente ${ }^{7}$

5 En Aristóteles, "natural" (como en "derecho natural" o "derecho por naturaleza") también connota objetividad o verdad: véase Fundamentals of Ethics, 24.

6 Mangabeira Unger, Roberto, Knowledge and Politics, Nueva York, Free Press, 1975, 77. Sobre éste y otros argumentos, véase Finnis, "On the Critical Legal Studies Movement”, en J. Eckelaar y J. Bella (eds.), Oxford Essays in Furisprudence: Third Series, Oxford, Oxford U. P., 1987, 144-165; o en American fournal of Jurisprudence, 30, 1985, 21-42.

7 Pero no exclusivamente; las ambigüedades surgen aquí de varias fuentes, fenomenales y culturales; de esa manera, se puede decir que los movimientos 
en la distinción entre razón y sentimiento. En su sentido central, fuerte, la elección libre es la adopción de una entre dos o más opciones alternativas, racionalmente atractivas e incompatibles, tales que sólo la elección misma determina cuál opción es elegida y perseguida. ${ }^{8}$ Muchos aspectos de la vida social e individual y muchas obligaciones individuales y sociales están estructuradas por la elección entre opciones racionalmente atractivas, cuyo atractivo racional puede ser explicado, esencialmente, en términos de oportunidades humanas básicas, entendidas como objetivamente buenas (aunque realizables de diferente manera). Ningún sentido completo de "objetividad" y de "verdad" puede ser atribuido, aquí o en cualquier parte, de otra manera que en términos de juicios racionales abiertos a todas las cuestiones pertinentes.

Pero si los bienes humanos básicos, por su objetividad y verdad, hacen tan accesible la libre elección ¿cuáles pueden ser las bases para identificar las elecciones que, aunque racionales, deben ser rechazadas porque son irrazonables, incorrectas o inmorales?

El pensamiento moral es simplemente pensamiento racional en su máxima extensión, que integra las emociones y los sentimientos, pero sin someterse a ellos. El principio fundamental de la racionalidad práctica es "toma como premisa al menos una de las razones básicas para la acción y síguela hasta el punto en que, de alguna manera, des lugar a la concreción de este bien en la acción. No actúes sin sentido". El principio fundamental del pensamiento moral es, simplemente, la exigencia de ser completamente racional; en tanto cuanto esté en tu poder, no admitas nada más que las razones básicas para la acción, para dar forma a tu pensamiento práctico en tanto encuentras, desarrollas y utilizas las oportunidades para lograr el desarrollo humano a

son "elegidos" y "libres" en tanto no son objeto de compulsiones físicas o compulsiones "externas" o sociales, y así sucesivamente.

8 Sobre la libre elección y sus condiciones, véase, por ejemplo, Finnis et al., Nuclear Deterrence, 256-60; Boyle, Joseph et al., A Self-Referential Arguments, Notre Dame, Ind, Notre Dame U. P., 1976; Aquino, Tomás de, De Malo, q. 6, a. um. 
través de acciones elegidas. Sé enteramente razonable. ${ }^{9}$ La frase de Aristóteles orthos logos y de sus posteriores seguidores recta ratio, recta razón, debería simplemente ser comprendida como "razón destrabada", razón no desviada por las emociones y los sentimientos. De este modo, la razón no desviada y la voluntad moralmente buena están guiadas por el primer principio moral: que se debe elegir (o de otra manera, querer) aquellas y solamente aquellas posibilidades cuyo quererlas es compatible con una voluntad dirigida hacia el desarrollo completo de todas las personas humanas, en todos sus bienes básicos hacia el ideal de la realización humana integral".

Tomemos una forma paradigmática de inmoralidad. La emoción puede hacer que uno desee destruir o dañar lo bueno de la vida en alguien que uno odia; o lo bueno del conocimiento; así, uno mata o injuria o engaña a aquella persona sólo por sentimiento de aversión. Ello es inmoral, porque aquí hay un principio moral general, por decir así, metodológico, intermedio entre los principios más básicos de la razón práctica (los bienes básicos o las razones para la acción y el primer principio moral) y las normas morales particulares contra la muerte o la mentira. Este principio moral intermedio, que algunos llaman un "modo de responsabilidad", 10 excluirá el pagar la injuria con la injuria o responder a la propia debilidad o contrariedades con la propia destrucción.

Tal vez más inmediatamente apropiado a la teoría política y jurídica es el principio moral intermedio que requiere que uno actúe imparcialmente: que uno no limite su interés por los bienes humanos básicos simplemente a los propios sentimientos de autopreferencia o de preferencia por aquellos que están cerca y son queridos. La imparcialidad (y su paradigmática formulación en la regla de oro) no excluye el tratar a personas diferentes en forma

9 Véase Grisez et al., Nuclear Deterrence, 119-25.

10 Cfr. Nuclear Deterrence, en 284-7; en Natural Law, 100-13, los llamo "requerimientos básicos de la razonabilidad práctica", y en Fundamentals of Ethics, 69, 70, 74-6, los llamo "principios morales intermedios". 
diferente; requiere solamente que el tratamiento diferencial esté justificado, ya sea por los límites inevitables del propio accionar o por los requerimientos inteligibles de los bienes básicos. Diré algo más (VII en adelante) sobre el rol legítimo de los sentimientos al efectuar elecciones imparciales en las que uno prioriza bienes (o concreciones de los bienes básicos) por los propios sentimientos, sin priorizar a las personas simplemente por sentimientos.

Hay otros principios morales intermedios. Es muy importante, para la estructuración del pensamiento jurídico, el principio que excluye el actuar contra una razón básica, al elegir la destrucción o el daño de algún bien básico, en cualquiera de sus concreciones en la persona humana (VI en adelante). Un bien humano básico siempre es una razón para la acción y siempre proporciona una "razón" para no elegir, destruir, dañar o impedir alguna concreción de ese bien; pero desde que las concreciones del bien humano comprometidas en alguna elección moralmente significativa no son conmensurables por la razón antes de la elección, nunca puede haber una razón suficiente para no tomar esa razón negativa como decisiva para la elección. Solamente los factores emocionales, tales como el deseo o la aversión, podrían motivar una elección que lo rechazara.

Sin duda, las razones básicas para la acción, como la frase lo sugiere, presentan muchas razones para la elección y para la acción; muchas razones para... Y desde que uno es finito, la propia elección de algún propósito, aunque sea de largo alcance, inevitablemente tendrá como efecto lateral algún impacto negativo (al menos, la no realización de) sobre otras concreciones posibles de éste o de otros bienes básicos. En este sentido, cada elección está "en contra de alguna razón básica", pero sólo como efecto lateral. En las elecciones que están excluidas por el principio moral intermedio ahora en cuestión, el daño o el perjuicio o el impedimento de la concreción de un bien básico (el daño de algún aspecto básico de la existencia y el bienestar de alguien) es elegido como medio, es decir, "como parte" de la descripción de la opción adoptada por la elección. Mientras que el primer principio 
intermedio excluye hacer de tal daño o destrucción el propio fin, este principio excluye hacerlo el propio medio. Los conceptos de fin y medios (que definen una opción) vienen juntos en una concepción tan fundamental a nuestro derecho: la intención. ${ }^{11}$

\section{III}

Aun en un bosquejo tan rápido, empieza a hacerse claro que una teoría del derecho natural, que es primariamente una teoría de los bienes humanos como principios del razonamiento práctico, debe acomodarse en su exposición - como el mismo razonamiento práctico debe tomarlas en cuenta- a ciertas características de nuestro mundo.

Entre estas características están: la realidad de la libre elección y la significación de las elecciones como perdurables en el carácter del que elige, más allá del tiempo del comportamiento que las ejecuta; y la distinción entre lo que es elegido como fin o como medio (es decir, como intentado) y lo que está previsto y aceptado como efecto lateral (es decir como un efecto no intencional).

De nuevo, hay ciertos hechos básicos, como aquel que Robert Nozick pasa por alto al declarar que (virtualmente) todo llega al mundo ya asignado a alguien que tiene un derecho sobre él, siendo la realidad que, por el contrario, los recursos naturales, de los que todo lo hecho ha sido hecho, preexisten a todos los derechos y no vienen al mundo asignados a nadie en particular; los recursos del mundo son fundamentalmente comunes y ninguna teoría de los derechos puede, adecuadamente, asignar un recurso

11 Sobre la noción de intención, véase Finnis, "Intention and SideEffects", en Frey, R. G. y Morris, Christofer (eds.), Liability and Responsability: Essays in Law and Morals, Cambridge, Cambridge University Press, 1991, 32-64; para la relación entre el análisis de la acción aquí bosquejado y la forma de responsabilidad que excluye la elección de destruir, dañar o impedir cualquier determinación de todo bien humano básico, véase Nuclear Deterrence, 286-90. 
a una persona tan absolutamente como para negar esa comunidad original de las existencias del mundo. ${ }^{12}$

Una característica adicional del mundo, que ha de ser tenida en cuenta por una teoría completa del derecho natural, es la distinción entre los órdenes de la realidad con los que la razón humana está relacionada. Atendiendo a este conjunto de distinciones, veremos la segunda de las dos fuentes de ambigüedad que mencioné al principio.

Casi todos los estados de cosas humanas interesantes concretizan los cuatro órdenes de la realidad con que la razón humana está relacionada. Consideremos, por ejemplo, una conferencia: 1) uno oye los sonidos producidos por las cuerdas vocales del orador: hay un orden de la naturaleza que de ninguna manera establecemos por medio de nuestro entendimiento, pero que podemos investigar por medio de nuestro entendimiento como en las ciencias naturales o (como ahora) en la metafísica; 2) uno oye al orador exposiciones, argumentos, explicaciones y colocamos al propio entendimiento en sintonía con ellos (aunque sea solamente hasta el punto necesario para rechazarlos como equivocados); hay un orden que se puede dar a las propias investigaciones, comprehensiones y razonamientos; es el orden estudiado por la lógica, la metodología y la epistemología; 3) uno oye al conferenciante, quien (como la audiencia) está libremente comprometido en una actividad y, por lo tanto, participa en una relación humana; hay un orden que se puede poner en las propias disposiciones, eleccio-

12 Nozick, Robert, Anarchy, State and Utopia, Oxford, Blackwell, 1974, 160; Finnis, Natural Law, 187. Cfr. el principio del dominio eminente, o la forma en que las leyes de insolvencia, aun cuando son razonablemente variables entre país y país, están estructuradas todas alrededor de algún principio de igualdad entre los grupos de acreedores. Pero la implicación más obvia es el principio de que, en condiciones de gran escasez y privación, los bienes se vuelven de nuevo comunes, justo en la medida necesaria para permitir a aquellos que están en peligro, apropiarse de lo que necesitan para prevenir, por ejemplo, la hambruna; este principio moral puede calificar aun la definición legal del robo, ya sea directamente o por vía del concepto de (des)honestidad; véase Smith, J. C., Fustification and Excuse in the Criminal Law, Londres, Stevens, 1989, 50-2. 
nes y acciones - la propia "praxis", el propio hacer, la propia existenz-, el "orden existencial" estudiado por la biografía y la historia de los asuntos humanos y por la filosofía moral y política; 4) uno oye el idioma de la conferencia y las aseveraciones ordenadas por medio de una técnica retórica y expositiva, haciendo y descifrando los símbolos formalizados de un lenguaje, así como los menos formalizados, pero símbolos también convencionales, y las expresivas rutinas de una forma cultural y de una técnica: el orden que uno puede poner inteligentemente en la materia que está sujeta a nuestro poder, como para hacer objetos tales como fonemas, palabras, poemas, botes, software, misiles balísticos y sus trayectorias programadas - el orden de la "poiesis", del hacer, de la cultura - estudiado en las artes y las tecnologías, y en la lingüística y la retórica ${ }^{13}$ (correspondientes a estos cuatro órdenes hay cuatro sentidos de "oír", irreductibles y distintos).

Casi toda forma de deformación reduccionista en teoría social (digamos, política) y muchas incomprensiones destructivas en casi todos los aspectos de la teoría jurídica pueden ser rastreadas como un descuido de las complejidades y ambigüedades creadas por la irreductible distinción entre esos cuatro órdenes, cuya irreductibilidad de unos respecto de los otros está escondida por el hecho de que cada uno, en cierto modo, incluye a los demás.

La distinción particularmente relevante en teoría jurídica es la que existe entre el tercer orden (existencial, moral) y el cuarto orden (cultural, técnico). Pocas elecciones moralmente significativas pueden ser llevadas a cabo sin emplear alguna técnica formada culturalmente; y ninguna técnica puede ser habilitada para uso humano sin alguna elección moralmente significativa. Pero cada técnica tiene una integral inteligibilidad del cuarto

13 Para una explicación elemental (diferentemente enumerada), véase $\mathcal{N a}$ tural Law, 136-8; 157; para la exposición profunda, explicación y reflexión concerniente a los cuatro órdenes, véase Grisez, Germain, Beyond the New Theism: A Philosophy of Religion, Notre Dame, Ind, Notre Dame University Press, 1975, 230-40. 
orden, que puede ser totalmente explicada sin referencia a las elecciones moralmente significativas por las que pueden ser puestas en obra, así como a los principios morales del razonamiento práctico pertinentes a tales elecciones.

Entre las ambigüedades creadas por las distinciones entre el tercer y cuarto orden, está la ambigüedad del término "elección racional". Éste tiene, por lo menos, tres importantes sentidos diferentes:

1) una elección que es totalmente razonable se aviene a todos los requerimientos del razonamiento práctico y por eso es moralmente recta;

2) una elección que es racionalmente motivada en el sentido de que su objeto ha sido formado por la inteligencia práctica y tiene un atractivo racional, aun si está, en algunos aspectos, motivada esencialmente por el sentimiento más que por la razón; sentimientos que tienen, en alguna medida, restringida e instrumentalizada a la razón y esta elección es, por lo tanto, irrazonable e inmoral aunque sea racional;

3) una decisión y acción que es técnicamente (tecnológicamente) correcta, es decir, identificable de acuerdo con algún arte o técnica como la más efectiva para alcanzar el objetivo técnico relevante; típicamente la decisión por la cual existe, dentro de esta técnica (por ejemplo, este juego), una razón dominante que puede ser proporcionada a las razones en favor de las opciones alternativas y que incluye todo lo que éstas ofrecen y algunas más.

El sentido 3 es el único en el que los economistas y los exponentes de la teoría de los "juegos" o de la "decisión" usan comúnmente la frase "elección racional". Yo he usado los términos "racional" (y sus afines) y "elección", en la sección II, en el sentido 2 (o en los sentidos 1 y 2), pero nunca en el sentido 3. Aquí se da una oportunidad para malas interpretaciones. ${ }^{14}$ En los senti-

14 Véase Finnis, "Concluding Reflections", Cleveland State Law Rev., 38, 1990, 235-8. 
dos 1 y 2, lo que hace necesaria la elección racional es la inconmensurabilidad de los bienes y males inteligibles involucrados en las opciones alternativas; si las opciones fueran completamente conmensurables, las alternativas podrían ser identificadas como lisa y llanamente superiores e inferiores, y la inferior perdería su atracción racional, caería fuera de la deliberación racional; la elección racional sería innecesaria y, en un sentido significativo, imposible (VI más abajo). Pero en el sentido 3, la elección racional es posible sólo cuando una opción puede ser identificada como lisa y llanamente superior.

\section{IV}

El razonamiento y la racionalidad jurídica tienen, sugiero, su carácter distintivo y su peculiar evasividad, porque al servicio de un propósito del tercer orden, el existencial y moral de vivir juntos en un justo orden de relaciones imparciales y correctas, existe y se está construyendo un objeto del cuarto orden: "la ley" (como en "la ley de Inglaterra"). Ésta es un objeto cultural, bastante complejo, que comprende un vocabulario con muchos significados artificiosamente consignados, reglas que identifican decisiones y argumentos permitidos y excluidos y, correspondientemente, muchas rutinas técnicas o procesos (tales como alegatos, juicios, escrituras, etcétera), constituidos y regulados de acuerdo a ciertas fórmulas, significados asignados y reglas de argumentación y decisión.

Este objeto cultural, construido o (como se dice) establecido por elecciones humanas creativas, es un instrumento, una técnica adoptada para un propósito moral y adoptada porque no hay otra forma disponible de estar de acuerdo sobre los lapsos significativos de tiempo acerca de, precisamente, cómo perseguir bien el proyecto moral.

La autoridad política, en todas sus manifestaciones, incluyendo las instituciones jurídicas, es una técnica para obrar sin unanimidad al hacer elecciones sociales — donde la unanimidad 
sería, casi siempre, inasequible o temporaria - en orden a asegurar la prácticamente (casi) unanimidad sobre cómo coordinar las acciones (incluyendo las abstenciones) de los miembros de la sociedad. ${ }^{15}$

El razonamiento jurídico es, entonces (por lo menos en gran parte), un razonamiento técnico, no moral. Como todo razonamiento técnico, está ordenado a conseguir un propósito particular, un estado definido de cosas alcanzable por medio de la disposición eficiente de los medios hacia el fin. El fin particular es aquí la resolución de las disputas (y otras imputaciones de inconducta), por medio de la provisión de una directiva, suficientemente definida y específica, para identificar a una parte como correcta (en-lo-correcto) y a la otra como incorrecta (noen-lo-correcto).

De aquí los diferentes artificios de la ley: los términos definitorios y las reglas especificatorias con la suficiente y necesariamente artificial claridad y definición como para establecer las "líneas claras" que hacen de tantas cuestiones jurídicas de la vida real, "cuestiones fáciles". Las definiciones jurídicas y las reglas están para proveer al ciudadano, al asesor legal y al juez de un algoritmo (cálculo) para decidir en tantas cuestiones como sea posible - en principio, cada cuestión - si (o no) este curso de acción podría (o no) ser legítimo: este arreglo es válido; ese contrato está por terminar; estas pérdidas son compensables por los daños y aquéllas no lo son, y así sucesivamente. Tanto como es posible, la ley está para proveer los recursos de razonamiento - leyes y reglas basadas en las leyes, reglas de la ley común y costumbres - capacitadas para catalogar (conmensurar) resoluciones alternativas a las disputas como correctas o incorrectas y, por lo tanto, como mejores o peores.

15 Véase, además, Finnis, Natural Law, 231-7; Finnis, "The Authority of Law in the Predicament of Contemporary Social Theory", Notre Dame Fournal of Law, Ethics and Public Policy, 1984, 115-37; Finnis, "Law as Coordination", Ratio furis, 2, 1989, 97-104. 
Las herramientas de los abogados, su habilidad para encontrar y usar los recursos autoritativos, son medios al servicio de un propósito lo suficientemente definido como para constituir una técnica, una forma de razonamiento técnico. El propósito, otra vez, es la resolución inequívoca de cada disputa (otra cuestión es la decisión justa) que pueda ser, de alguna manera, prevista y realizada. Más aún, esta búsqueda de la certeza por medio de un conjunto completo de respuestas, unívocamente correctas, está en sí misma al servicio de un bien más amplio que, como todos los bienes humanos básicos, no es reducible a una meta definida, sino que más bien es un bien abierto, ilimitado, en el que las personas y sus comunidades pueden participar, sin capturar nunca, o exhaustivar, el bien de la justa armonía. Este bien es un bien moral en tanto es promovido por sí mismo y respetado como un aspecto del desarrollo integral humano ideal. Como bien moral, sus implicaciones están especificadas por todos los principios morales que le están vinculados.

Así emerge la tensión acerca de la cual discurre la obra de Ronald Dworkin sobre el razonamiento jurídico.

Dworkin busca resolver la tensión entre el carácter del razonamiento jurídico, como técnica culturalmente especificada para alcanzar respuestas predecibles a los problemas de coordinación social, y su carácter en cuanto, en cada uno de sus decisivos momentos judiciales, legislativos y ejecutivos, acto moral que participa de la justicia (o injusticia). Pienso que la resolución que intenta falla al captar la real naturaleza y las implicaciones de esa tensión.

En el razonamiento judicial, tal como está descrito por Dworkin, dos criterios de juicio son utilizados; como veremos, hay entre estos dos criterios una especie de inconmensurabilidad, análoga a la inconmensurabilidad entre los bienes humanos involucrados en las elecciones significativa y racionalmente 
motivadas. Uno de estos criterios o dimensiones pertenece a lo que he llamado el tercer orden o racionalidad (moral); y el otro, al cuarto orden (técnico). La primera dimensión es la que Dworkin llama "ajuste" (fit): coherencia con los "materiales" jurídicos existentes, creados por decisiones políticas pasadas, es decir, con la legislación y con la decisión judicial autoritativa (precedente). A la segunda dimensión la llama "justificación". ${ }^{16} \mathrm{Y}$ trata de demostrar que una única respuesta correcta ("lo recto") está disponible en la "mayoría" de los casos difíciles.

Se puede negar esta última tesis sin comprometerse con ningún tipo de escepticismo sobre la objetividad de los bienes humanos o sobre los juicios correctos acerca de lo bueno y lo malo. No necesita nuestra negativa estar referida al argumento popular que Dworkin está directamente comprometido a despreciar y demoler: el argumento de que el desacuerdo es endémico e inerradicable (porque el no estar de acuerdo es un mero hecho entre las personas y es lógicamente irrelevante para los méritos de cualquier práctica o reclamo interpretativo). No es necesario para negar la tesis de Dworkin sobre una-respuesta-correcta basarse en el hecho de que nadie tiene los poderes "sobrehumanos" del juez imaginario de Dworkin.

Aun un juez ideal, con poderes sobrehumanos, no podría buscar sensiblemente una única respuesta correcta para un caso

16 Véase Dworkin, Ronald, Law's Empire, Cambridge, Mass., Harvard University Press, 1986, 255. Este término parece confuso, ya que ambas dimensiones son, en esta explicación, necesarias para justificar una decisión judicial. $\mathrm{Su}$ nombre previo para la segunda dimensión (inherente y sustantivamente moral), "rectitud", era mejor; véase Dworkin, Taking Rights Seriously, Cambridge, Mass., Harvard University Press, 1978, 340-1. Además, los rótulos adoptados por Dworkin tienen el mérito de hacer claro este ajuste, precisamente porque una condición necesaria para asegurar ciertos bienes y requerimientos morales y políticos, tales como comunidad e integridad, es una cuestión de hechos históricos, es decir, hechos sobre cuáles juicios y decisiones han sido efectuados por las instituciones pertinentes en una sociedad dada, en un lapso de tiempo dado y la extensión en la cual el juicio o decisión actual o hipotética corresponde en contenido a previos juicios y decisiones. 
difícil (tal como los abogados, en los sistemas jurídicos sofisticados, usan el término "caso difícil"). Porque en tal caso la búsqueda de una respuesta correcta es prácticamente incoherente y sin sentido, de la misma manera que una investigación acerca de la novela inglesa que fuera "más romántica y corta" (o "más divertida y mejor" o "más inglesa y más profunda").

$\mathrm{Al}$ asumir con Dworkin que hay dos "dimensiones" o criterios de evaluación judicial, podemos decir que un caso es dificil para la decisión judicial (no meramente original), cuando no sólo hay más de una respuesta que no está en evidente violación de una regla aplicable, sino también que las respuestas que están disponibles pueden ser catalogadas en diferentes órdenes en razón de cada uno de los criterios de evaluación pertinentes: para las novelas, su brevedad y su idiosincrasia inglesa (o humor, o profundidad, o... ); para los juicios jurídicos, su adaptación a la legislación previa y al precedente y, déjesenos convenir (no conceder) con Dworkin, su inherente profundidad moral. ${ }^{17}$ En ese caso se encuentra lo que los teóricos de la "elección racional" (en el sentido 3) llaman "intransitividad", un fenómeno que esas teorías reconocen no poder manejar realmente: ${ }^{18}$ la solución A es mejor

17 A lo largo de toda esta discusión sobre las dimensiones de la valoración en Dworkin, daré por aceptada su aseveración de que la "moralidad y la salud moral" se refieren a una "dimensión de valoración" que puede estar, a veces, rectamente (en un cierto sentido de "recto" relevante a la deuda judicial) subordinada a algún otro criterio o criterios (tales como "ajuste"). Pero la verdad aquí es diferente, aunque no simple; la moralidad siempre triunfa sobre cualquier otro criterio de elección, aunque no de tal manera como para hacer irracional la elección inmoral; pero las condiciones verdaderas de cualquier verdad(es) moral relevante para un juez, incluyen hechos sobre el ajuste; si los hechos sobre el ajuste no pueden (en estándares de juicio moral) ser reconciliados con la moralidad, uno está, de hecho, en una situación de lex injusta, para lo cual véase Finnis, Natural Law, cap. 12.

18 En la "teoría del juego" - un vasto y sofisticado cuerpo de razonamiento sobre las situaciones de la vida ordinaria (por ejemplo, el "regateo"), y concebido como si aquellas tuvieran la simple, de objetivo unitario, autointeresada estructura de un juego competitivo-, el primer axioma es el de la transitividad: si "a" es mejor que "b"y "b" es mejor que "c", entonces "a” debe ser mejor que 
que la solución $\mathrm{B}$, en la escala del ajuste jurídico, y la $\mathrm{B}$ que la C, pero la $\mathrm{C}$ es mejor que la A en la escala de la "fuerza moral"; así es que no hay suficiente razón para declarar a $\mathrm{A}$ o a $\mathrm{B}$, o a $\mathrm{C}$ como la absolutamente mejor decisión judicial. Si el orden de calificación fue el mismo en ambas dimensiones, por supuesto el caso no fue un caso difícil, y el sistema legal ya tenía lo que siempre se desea de él: una única respuesta correcta.

En sus obras anteriores a Law's Empire, Dworkin trató de superar esa inconmensurabilidad de las dimensiones o criterios de evaluación, al proponer una especie de orden lexicográfico (en la terminología de Rawls: "lexical"). Los candidatos para el "mejor informe" sobre el derecho de Inglaterra en 1980 debían fijar adecuadamente el material legal inglés entonces existente y, entre los que satisfacen este criterio umbral, aquel que se sitúa más alto en el otro criterio (fuerza moral), sería sobre todo y absolutamente "el mejor", aunque se sitúe como menos ajustado que los demás. ${ }^{19}$ Pero esta solución era vacía, ya que no identificaba ningún criterio, aunque sea en esbozo o "en principio", para especificar

“c”; si "x" es peor que “y” e “y” que "z", entonces "x" es peor que “z”, etcétera, y de modo similar para los predicados comparativos diversos de "es mejor que", o "es peor que", por ejemplo "es preferible a"... Véase H. D. Luce y H. Raiffa, Games and Decisions, New York, Wiley, 1957, cap. 1. Maestros inteligentes de la teoría del juego reconocen que, en la vida real, las intransitividades abundan: "a" es mejor que "b" en un aspecto (por ejemplo la proximidad de la escuela), y "b" es mejor que "c", en otro aspecto (por ejemplo los entretenimientos físicos), pero ya que las dos bases de comparación (proximidad y entretenimientos) no son conmensurables unas con otras, no se sigue que "a" sea mejor que "c" en cualquier aspecto, incalificadamente. De esta manera, Luce y Raiffa están obligados a decir: "Podemos decir que nos referimos solamente al comportamiento que es transitivo", agregando esperanzadamente que "creemos que esto no necesita ser siempre un estudio vacuo" (ibidem, 25). En la misma página, reconocen la causa típica y el efecto de las intransitividades: un tópico o una situación fuerzan "elecciones entre alternativas inherentemente incomparables". La idea es que cada alternativa invoca "respuestas" sobre muchas escalas de "atributos" diferentes y eso, aunque cada escala pueda ser transitiva en sí misma, su amalgamamiento no necesariamente lo es.

19 Véase, por ejemplo, Dworkin, Taking Rights Seriously, 340-2. 
cuándo es adecuado "el ajustamiento", es decir, para situar el umbral (del ajuste) más allá de cuál criterio de la fuerza moral pudiera prevalecer (es como si a uno le dijeran que buscara, para la novela más divertida, entre aquellas que son "bastante cortas"). Presumiblemente, los candidatos para la respuesta correcta a la pregunta “¿Cuándo es adecuado el ajustamiento?” estarían catalogados en términos tanto de ajuste como de profundidad. Una regresión al infinito, de la viciosa clase que anula las explicaciones racionales, estaba en marcha.

En Law's Empire, Dworkin abandona la descripción de una simple ordenación lexical entre esos dos criterios. Nos hemos quedado con poco menos que una metáfora: "balance" como en "balance general de las virtudes políticas", incluidas en las interpretaciones competitivas o descripciones de la ley [de Inglaterra (en 1990)]. Pero, en ausencia de algún baremo que pudiera conmensurar los diferentes criterios, las instrucciones para el balance (o mejor para sopesar) pueden legítimamente significar poco más que: "tenga en mente, conscientemente, todos los hechos relevantes y elija". O en la esfera jurídica: "Oiga los argumentos, sentado en la más Alta Corte y luego vote".

$\mathrm{Al}$ comprender la racionalidad práctica en todas sus formas, se puede apreciar una característica de la experiencia de la elección. Después que uno ha elegido, los factores que favorecen la opción elegida parecerán, generalmente, sobrepasar o sobrebalancear aquellos que favorecen las opciones alternativas rechazadas. La opción elegida - hacer " $\mathrm{x}$ ", adoptar la regla o la interpretación "y" - parecerá generalmente (a la persona que eligió aunque no a los observadores) tener una supremacía, una única rectitud. Pero este sentido de supremacía, de la corrección de una opción (la elegida), no alterará la verdad de que la elección no estaba racionalmente determinada, es decir, no estaba guiada por la identificación de una opción o respuesta como "la correcta" (y esto no significa que fuera irracional; estaba entre las opciones racionalmente atractivas). Más bien, la elección estableció la respuesta "correcta", es decir, la establecida, en última instan- 
cia, por referencia a las disposiciones y sentimientos del elector. ${ }^{20}$ Cuando la elección en un caso difícil está hecha por (la mayoría) de la más alta corte (un mero asunto fáctico), la única rectitud de la respuesta está establecida no solamente por la actitud de aquellos que la han elegido, sino también para el sistema jurídico o la comunidad para la cual ha sido autoritativamente decidido y establecido como en una regla.

\section{VI}

La inconmensurabilidad de las dos dimensiones o criterios de Dworkin para el juicio judicial tiene significativas similitudes con la inconmensurabilidad de los bienes (y razones) comprometidos en las opciones alternativas disponibles para la elección moralmente significativa, en cualquier contexto. La racionalidad moral y política que sostiene (aunque no agota) la racionalidad jurídica, no puede ser entendida sin una comprensión de la inconmensurabilidad.

La inconmensurabilidad, la ausencia de cualquier baremo racionalmente identificable para medir, o de una escala para sopesar los bienes y los males en debate, es mucho más penetrante e intensa de lo que se podría imaginar de la simple descripción dworkiniana del razonamiento jurídico, a lo largo de las dos dimensiones de adecuación o ajuste legal y solidez moral. Uno encuentra la inconmensurabilidad en contextos sencillos, tales como tener que elegir entre ir a una conferencia, leer un buen libro, ir al cine y hablar con los amigos. Uno la encuentra en relación con las grandes elecciones sociales, como rechazar o repudiar la disuación nuclear: ${ }^{21}$ explorando tal elección se ilustrará ampliamente la impotencia de todas las formas de razonamiento

20 Véase Grisez, "Against Consequentialism", American Fournal of Furisprudence, 23, 1978, 46-7.

21 Véase Finnis et al., Nuclear Deterrence, Morality and Realism, 207-72; Raz, Joseph, The Morality of Freedom, Oxford, Oxford University Press, 1986, 321-66, explora la inconmensurabilidad con algunas conclusiones similares. 
agregativo para una elección moralmente significativa, elección aparte de la tarea puramente técnica o tecnológica de identificar los más costo-eficientes medios para una única meta limitada.

El razonamiento más característico de la racionalidad técnica es el "análisis del costo-beneficio", que compara los costos de las opciones alternativas con los beneficios probables. ${ }^{22}$ Esto puede ser llevado a cabo, con entera racionalidad, cuando: a) las metas están bien definidas, $b$ ) los costos pueden ser comparados con algunas unidades definidas (por ejemplo el dinero), c) los beneficios pueden ser también cuantificados, de forma que resulten conmensurables unos con otros, y d) las diferencias entre los medios, además de su eficiencia, los costos mensurables y beneficios mensurables, no son considerados como significativos. Ninguna de estas condiciones se cumple en el razonamiento moral.

Por supuesto, la elección moralmente significativa sería innecesaria y, con una cualificación, ${ }^{23}$ imposible, si una opción pu-

22 Hay otras formas de razonamiento en el cuarto orden, el cultural, por ejemplo el estético. Aquí los artífices no están guiados por una meta adecuadamente identificable independientemente de los medios eficaces que ellos puedan calcular y adoptar para alcanzarlo; la creación artística, de esta manera, excede a la técnica. En cambio, tales artífices, respondiendo a la sensible particularidad del asunto sobre o con el cual trabajan, están, cada uno, guiados por un "sentido" del objeto, un sentido que no puede ser articulado de otra manera que por la producción del objeto, el cual sirve para medir la adecuación de cualquier intento particular. Hay una interacción entre el proceso de creación y esa "concepción" o "anticipación" imaginativa del objeto; la anticipación puede ser perfeccionada o alterada, aun radicalmente, sin desaparecer durante el proceso. Valorar lo artístico, el valor estético (bondad o maldad) del producto final, involucra una apreciación estética de la unidad entre "lo que la obra está tratando de decir" y "cómo lo está diciendo"; la comprensión estética no viene a descansar en cada extremo, ni tampoco usa un criterio completamente anterior y externo a la composición misma. Supuesto que una composición tiene una especie de unidad interior, claridad e integridad, puede tener un valor estético que puede gobernar y reformar, más bien que ser gobernada por modelos preexistentes que generalizan los caracteres de objetos estéticos previos que, por su propia unidad interior, claridad e integridad, establezcan por ellos mismos su valor artístico.

23 La cualificación: puede haber elección (digamos) entre dos opciones, una de las cuales está racionalmente motivada, pero la otra, aunque formada en 
diera ser demostrada como la mejor, en una sola escala que como todo razonamiento agregativo, jerarquizara las opciones en un único orden transitivo. Si hubiera una razón (para hacer " $\mathrm{x}$ ") que algún método racional de comparación (por ejemplo la suma de los bienes y de los males en un análisis completo del costobeneficio), identificara como racionalmente preferible, la razón alternativa (contra hacer "x"), al estar así identificada como racionalmente inferior, cesaría de ser racionalmente atractiva, al menos en esa situación de elección. La razón así identificada como dominante, como incualificadamente preferible y la opción favorecida por esa razón, sería racionalmente carente de oposición. Allí no cabría ninguna elección, del tipo que esas teorías morales buscan guiar, porque las elecciones moralmente significativas que las teorías morales buscan orientar se dan entre opciones alternativas que poseen un requerimiento racional.

Identificar ciertas opciones como moralmente incorrectas no supone identificar una opción como (moralmente) la única correcta. Por supuesto, aun cuando una opción pueda ser juzgada como la única opción (moralmente) correcta para una persona dada (un juicio moral que solamente los principales compromisos de esa persona y sus disposiciones harán posible), esto implica solamente que las opciones inmorales alternativas no son totalmente racionales. Eso no implica, de ninguna manera, que esas opciones alternativas sean irracionales, es decir, carentes de atractivo racional en términos de bienes humanos, genuinos e inteligibles, que serían asegurados por las opciones inmorales y sacrificados por la opción moralmente recta. Racionalmente motivada de esta manera, la elección moralmente significativa resulta posible - por supuesto, es característica de la situación humana - aun en el caso, quizá relativamente poco común, de "una respuesta (opción) moral correcta".

su estructura de medios por la inteligencia, está motivada, en última instancia, sólo por el sentimiento. Pero ésta no es la clase de elección que concierne al razonamiento moral, aunque la lucha contra las tentaciones que surgen de las motivaciones emocionales tiene innegablemente significación moral. 
Pero cuando los razonamientos técnicos identifican a una opción como la únicamente correcta, es decir, como dominante, lo hacen demostrando que ella ofrece todo lo que las otras opciones ofrecen y algo más; ella es incalificadamente mejor. Las otras opciones, entonces, carecen de atractivo racional. Tal deliberación no termina en una elección - en el sentido más rico y central de este término ambiguo - sino en la comprensión, la "decisión" (no en la elección sino en el juicio racionalmente formado) y la acción.

Uno de los principios de la moralidad, ya lo he dicho (II más arriba), excluye el actuar contra una razón básica al elegir la destrucción o el daño de cualquier bien humano básico, en cualquiera de sus determinaciones. Porque esas determinaciones no son sino aspectos de las personas humanas, presentes y futuras, y las personas humanas no pueden ser racionalmente reducidas a factores conmensurables captados por el razonamiento técnico. Estas concreciones del bien humano constituyen razones en contra de cualquier opción que involucre la elección (intención) de destruir o dañar cualquiera de ellas. La significación de la inconmensurabilidad de los bienes involucrados en tales opciones moralmente significativas está en que ninguna razón para tal opción puede ser racionalmente preferible a esa razón en contra. Y lo mismo es verdadero para la razón en contra de una opción que esté constituida por la parcialidad de tal opción.

Se puede preguntar ¿cuáles son las razones para regular la propia elección, de acuerdo a una razón-contra, más bien que por cualquier razón-para? De nuevo, ellas no pueden ser establecidas sin referencia a algunas características de nuestro mundo, el contexto fundamental de toda elección humana. Las opciones que son razones para mi elección son infinitas en número. Siendo finito, simplemente no puedo hacer todo, no puedo elegir cada opción para la que existan razones. Pero puedo abstenerme de hacer algo, puedo respetar cada seria razón en su contra. Así es que un deber afirmativo incondicional o absoluto (deber de...), impondría un peso imposible y sería irracional; pero los absolutos morales negativos (deberes de no...), si están correctamente 
establecidos, en atención a la distinción entre intención y efectos colaterales, pueden ser siempre impuestos, en cualquiera o en todas las circunstancias.

Además, muchos bienes humanos (por ejemplo las vidas de los demás) son regalos, dones, que podemos destruir o dañar, pero que no podemos crear. Aquí también hay un fundamento de la asimetría inteligible entre las razones-para y las razones-contra. Tampoco la prioridad, dentro de su ámbito, de las razones-contra otorga a la moralidad como un todo un carácter negativo o eleva a la pureza moral al rango de una meta suprema. El primer elemento del primer principio de la razón práctica sigue siendo que el bien humano tiene que ser hecho y perseguido. El segundo elemento es que el mal tiene que ser evitado. Pero un completo respeto y una adhesión a los deberes absolutos de evitar el mal deja un campo abierto para (más numerosas) responsabilidades positivas, individuales y sociales.

\section{VII}

Los absolutos morales dan al razonamiento legal su esqueleto: la exclusión del asesinato intencional; de la injuria intencional hacia la persona y aun de los intereses económicos de la persona; del fraude deliberado, ${ }^{24}$ en vista a asegurar los resultados deseados;

24 La ley inglesa declara no reconocer el principio de que el intento de dañar es suficiente para hacer ilegal una acción legal. Bradford Corporation versus Pickles (1895) A. C. 587; Allen versus Flood (1898) A. C. 1. Pero la significación de esta declaración está reducida considerablemente por (i) la doctrina establecida en Quinn versus Leathem (1901) A. C. 495, y Crofter Hand Woven Harris Tweed versus Veitch (1942) A. C. 435, de que un acuerdo para actuar que dañe al demandante con la intención predominante de perjudicarlo es un agravio aun si los actos en sí mismos son de otra manera legales, y por (ii) las siguientes doctrinas que transforman acciones en agravios para aquellos que están dañados por un acto incorrecto, por ejemplo de fraude, induciendo o amenazando la ruptura de un contrato, etcétera, cuando ese acto está intentando dañarlos, aun cuando ellos no tuvieran de otro modo acción con respecto al fraude, la intimidación o la ruptura o interferencia del contrato; véase, por ejemplo, Lonrho plc versus Fayed 
de la esclavitud, que trata a la persona humana como a un objeto de bajo rango, de ser más bien que como un sujeto humano autónomo. Estos absolutos morales que "son racionalmente determinados y esencialmente determinables constituyen los derechos humanos más básicos; y los fundamentos de la ley criminal y de las leyes de daños intencionales o delitos, para no mencionar todas las leyes, principios y doctrinas que penalizan el fraude intencional, retirándole todo apoyo legal directo y excluyéndolo del proceso legal".

La racionalidad de todas estas normas, morales y jurídicas, depende de la inconmensurabilidad de los bienes y males humanos en juego en opciones para elección moralmente significativas. Esta inconmensurabilidad tiene ulteriores implicaciones de importancia para el razonamiento jurídico.

El centro de la norma moral de imparcialidad es la regla de oro: "haz a los demás lo que desearías que te hicieran a ti; no im-

(1991) 3 AH E. R. 303 (HL). Además, el carácter fundacional de la doctrina en Bradford Corporation versus Pickles y Allen versus Flood está cuestionado por el hecho que, en América, ella ha sido rechazada: véase Barr Ames, James, "Hasta qué punto un acto puede ser una injuria debido al injusto móvil del actor", 18 (1905), 411-22, y Prosser on Torts, sect. 130. Además, la adopción, por la Cámara de los Lores, en 1890, del principio de que el móvil solo no puede hacer ilegal un acto individual, fue profundamente confundido, por un análisis imperfecto de la acción y de la intención. (1) Hubo una falla fundamental al distinguir sentimientos de razones para la acción, por ejemplo Lord Watson expresó ese principio de esta manera: "Cuando el acto dado es legal, aparte de los sentimientos que lo impulsan, la ley civil tendría que no tomar conocimiento de su móvil" [(1898) A. C. a. 94]. (2) Correspondientemente, hubo una falla para ver que los actos deberían ser descritos, identificados, en términos de los fines y de los medios identificados en las deliberaciones que formulan las opciones entre las que el actor elige y así se debe distinguir claramente entre fines, medios y efectos laterales; el argumento que los lores rechazaron en 1898 incluía junto a la "malicia" un propósito de "beneficiarse a expensas de su vecino", lo que confunde el caso donde la pérdida para el vecino es el objeto (y el beneficio financiero para sí no es más que un efecto lateral bienvenido), con el caso en donde el beneficio financiero para sí mismo es el objeto (y la pérdida para el vecino nada más que prevista, tal vez un efecto lateral bienvenido); los lores rechazaron el argumento sin identificar esta radical ambigüedad. 
pongas a los demás lo que no quieres que te obliguen a aceptar". Esto tiene dos aspectos. Primero: la racionalidad práctica, fuera del limitado contexto técnico de los juegos competitivos, incluye una norma racional de imparcialidad. Esta norma no excluye todas las formas y sentimientos de preferencia por sí mismo y por aquellos que están cerca y son queridos, sino más bien todas aquellas formas de preferencia que están motivadas solamente por deseos, aversiones u hostilidades que no corresponden a los aspectos inteligibles de las razones reales para la acción: los bienes humanos básicos realizables en las vidas de otros seres humanos, así como en la vida de uno mismo y de aquellos que están cerca de nuestro corazón.

El segundo aspecto de la regla de oro es este: aunque la imparcialidad sea una norma racional que requiere trascender todos nuestros sentimientos no integrados racionalmente, su aplicación concreta en la vida personal presupone una conmensuración de los beneficios y de las cargas que la razón es impotente para conmensurar. Porque para aplicar la regla de oro se debe saber qué cargas se consideran demasiado grandes para aceptarlas. Y este conocimiento, que constituye una conmensuración pre-moral, no puede serlo por una conmensuración racional. Por lo tanto, sólo puede ser la propia conciencia intuitiva el propio discernimiento de los propios "sentimientos" hacia varios bienes y males, como concretamente recordados, experimentados o imaginados. Esto, lo repito, no es una conmensuración racional y objetiva de los bienes y de los males; pero una vez establecidos en nuestros sentimientos e identificados en nuestra conciencia, capacitan para medir nuestras opciones por medio de un estándar objetivo y racional de imparcialidad interpersonal.

Analógicamente, en la vida de una comunidad, la conmensuración preliminar de los factores racionalmente inconmensurables se cumple no por juicios racionalmente determinados, sino por "decisiones" (elecciones). ¿Es justo imponer a los demás los riesgos inherentes a conducir a más de 10 millas por hora? En nuestra comunidad sí, ya que nuestra comunidad ha decidido, 
por costumbre y por ley, tratar esos riesgos y daños como no demasiado grandes. ¿Tenemos una crítica racional para una comunidad que decidiera limitar el tráfico en las rutas a 10 millas por hora y aceptar todos los costos económicos y de otra clase de tal decisión? ¿O no tener la institución de los trusts o de trusts inmobiliarios? No, no tenemos ninguna crítica racional para tal comunidad. Pero sí tenemos una crítica racional para alguien que conduce a 60 millas por hora, pero que, cuando es chocado por otro, se queja y alega que el mero hecho de que la velocidad del otro excediera las 10 millas por hora establece la negligencia del otro. $\mathrm{O}$ de aquellos que desean recibir los beneficios de los trusts (por ejemplo beneficios en las tasas), pero no quieren aceptar la distinción de la ley entre trust y contrato en el caso de quiebra.

En general, tenemos una crítica racional para alguien que acepta los beneficios de estas u otras decisiones generales, pero rechaza las cargas cuando pesan sobre él y sobre aquellos por los que se siente interesado. En definitiva, la decisión de permitir al tráfico de las rutas circular a más de 10 millas por hora, o de definir los trusts tal como lo hace la ley inglesa, era racionalmente indeterminada. ${ }^{25}$ Esto no significa que no esté completamente guiada por la razón; el bien de la vida corporal humana y de la integridad es una razón genuina, siempre prácticamente relevante, y la demanda racional de consistencia con nuestra tolerancia individual y común o intolerancia para con otras amenazas - no del tráfico - a ese bien, provee de cierto criterio racional para la decisión. Y, similarmente, para con los trusts, cuya racionalidad desafió mu-

25 Por supuesto, esto no significa que fuera "indeterminado", en el sentido fuerte de la palabra, que el Movimiento de Estudios Crítico-Jurídicos usa tan vagamente y no rigurosamente, por ejemplo indeterminado en el sentido de estar completamente sin la guía de la razón (véase Finnis, "On the Critical Legal Studies Movement", 147, 157-61). Porque el bien de la vida corporal y la integridad es una razón genuina, prácticamente relevante, y un criterio racional adicional para la decisión está proporcionado por los hechos acerca de los tiempos de reacción humanos y la susceptibilidad a los impactos, y por la demanda racional de compatibilidad con nuestra tolerancia, o la intolerancia individual y colectiva de otras - no del tráfico - amenazas a ese bien. 
chos intentos legislativos, durante centurias, para suprimir esta peculiar doble propiedad. Sin embargo, aunque racionalmente indeterminada, la decisión de permitir un movimiento más rápido del tráfico, una vez hecha, provee un modelo racional, completamente determinado, para tratar a aquellos acusados de incorrección o a los que infligen incorrectamente un daño. Tal como sucede con los trusts en bancarrota.

En el desarrollo del proceso jurídico, mucho gira sobre el principio - principio de imparcialidad - de que los litigantes (y otros involucrados en el proceso) deberían ser tratados por los jueces (y por otros con poder de decisión) imparcialmente, en el sentido de que deberán ser tratados, en tanto como sea posible, por cada juez tal como debieran ser tratados por cualquier otro juez. Creo que, sobre todo, es esto lo que conduce al derecho hacia lo artificial, la racionalidad de establecer y perseguir un conjunto de normas positivas, identificables, en tanto sea posible, simplemente por sus "fuentes" (por ejemplo por el hecho de su promulgación u otro suceso constitutivo) y aplicadas, tanto como sea posible, de acuerdo con su significado estipulado públicamente; dilucidado éste con la menor referencia posible a las consideraciones que, porque no están controladas por los hechos referidos a las fuentes (acontecimientos constitutivos), es probable que sean traídas a colación diferentemente por los diferentes jueces. Esta orientación al aislamiento de lo jurídico respecto del razonamiento moral no puede jamás ser completa.

La inconmensurabilidad tiene ulteriores implicaciones vinculadas al razonamiento jurídico. Ella descarta la técnica propuesta para el razonamiento jurídico conocida como "análisis económico del derecho". Porque es central en esa técnica que cada pegunta seria acerca del orden social pueda ser resuelta por la agregación del bien total neto prometido por las opciones alternativas, en términos de un factor simple conmensurante (o maximizador), a saber, la riqueza medida en términos del dinero que los actores sociales relevantes estarían deseosos y fueran capaces de pagar para asegurar su opción preferida. Igualmente impor- 
tante para el análisis económico es la concepción o tesis de que no hay diferencia de principio entre comprar el derecho de infligir intencionalmente un daño y comprar el derecho de no tomar precauciones que eliminarían un número equivalente de daños causados accidentalmente. ${ }^{26}$ Una posición crítica del análisis económico del derecho enfocará estas dos características suyas. Críticas menos fundamentales, como las de Dworkin (provechosas y que valen la pena), ${ }^{27}$ dejan a estas características intactas. Por supuesto, la propia distinción de Dworkin entre los derechos y las metas colectivas (estas últimas propuestas por Dworkin como legítimo ámbito de las legislaturas) es una distinción que supone acríticamente que las metas colectivas pueden ser racionalmente identificadas y preferidas a las alternativas por agregación de valor, sin hacer caso a los principios de imparcialidad distributiva y otros aspectos de la justicia, principios que en sí mismos constituyen derechos y que no pueden ser negociados de acuerdo con ninguna metodología racional, contra las mensurables cantidades de valor. ${ }^{28}$

\section{VIII}

En suma, gran parte de la teoría académica sobre el razonamiento judicial exagera grandemente el alcance con el cual la razón puede establecer cuál es el mayor bien y el menor mal. Al mismo tiempo, tal teoría minimiza la necesidad de fuentes autoritativas. Tales fuentes, en tanto que son claras y respetan los pocos derechos y deberes morales absolutos, tienen que ser respetadas como las únicas bases razonables para el razonamiento y decisión judi-

26 Véase Finnis, "Allocating Risks and Suffering", Cleveland State Law Review, 38, 1990, 200.

27 Dworkin, A Matter of Principle, Cambridge, Mass, Harvard University Press, 1985, pt. IV.

28 Véase Finnis, "A Bill of Rights for Britan? The Moral of Contemporary Jurisprudence", Proc. Brit. Acad., 71, 1985, 318-22. 
cial, en relación con aquellos incontables puntos de disputa que no involucran directamente derechos y deberes absolutos. Una teoría del derecho natural de la tradición clásica no pretende que la razón natural puede identificar la respuesta correcta a las incontables preguntas que surgen para el juez cuando encuentra las fuentes poco claras.

Desde el punto de vista clásico, expresado por Tomás de Aquino con una clara deuda hacia Aristóteles, ${ }^{29}$ hay muchas formas de andar mal y actuar mal; pero en muchas, tal vez en la mayoría de las situaciones de la vida personal y social, hay un buen número de opciones "correctas" (es decir, no malas) incompatibles. Las principales elecciones personales o las decisiones sociales autoritativas pueden reducir grandemente esta variedad de opciones para la persona que ha hecho este compromiso o para la comunidad que acepta tal autoridad. Todavía, esas elecciones y decisiones, aun cuando razonables y racionales, son en la mayoría de los casos no requeridas por la razón. No están precedidas por ningún juicio racional acerca de que esta opción es la respuesta correcta o la mejor solución.

29 Véase Aquino, Tomás de, Summa Theologiae, Ia-IIae, q. 95, a. 2; Aristóteles, Nicomachean Ethics, 5, 10, $1134^{\mathrm{b}}$ 19-1135 6; Finnis, "Natural Law", 28190, 294-5. 


\section{DEREGHO, MORAL Y "ORIENTACIÓN SEXUAL"*}

I. Durante los últimos treinta años, ha surgido en Europa un patrón común para reglamentar legalmente la conducta sexual. Este patrón o plan, al que llamaré "posición [europea] moderna predominante", es aceptado por la Corte Europea de Derechos Humanos y la Comisión Europea de Derechos Humanos (las dos instituciones judiciales y cuasi-judiciales supranacionales de la Convención Europea para la Protección de los Derechos Humanos y las Libertades Fundamentales [1950], a la cual pertenece la gran mayoría de los Estados europeos, miembros o no de la Comunidad [Económica] Europea, ahora conocida como Unión Europea). La posición europea moderna predominante tiene dos puntos de apoyo. Por una parte, el Estado no está autorizado a tipificar como delito (y de hecho no lo hace) al acto sexual inmoral (por ejemplo, al acto homosexual), privado, entre personas adultas que hubieran prestado su consentimiento. Por otra parte, los Estados sí tienen autoridad para desalentar, digamos, la conducta y la "orientación" homosexual (esto es, el deseo abiertamente manifiesto de intervenir en una conducta homosexual). Y por lo común, aunque no universalmente, lo hacen. Es decir, los Estados mantienen leyes y políticas criminales y administrativas que tienen entre sus fines desalentar tal conducta. Muchas de estas leyes, reglamentaciones y políticas discriminan (distinguen) entre la conducta heterosexual y homosexual de manera adversa para esta última.

En Inglaterra, por ejemplo, tiempo después de que el Parlamento desincriminara la conducta privada del homosexual adulto

* Traducción de "Law, morality and sexual orientation", Notre Dame Law Review, vol. 69, t. 5, 1994, a cargo de Jorge Ignacio Oría. Publicado originalmente en Persona y Derecho, Pamplona, núm. 41, 1999. 
por medio del Acta de Ofensas Sexuales de 1967, la Cámara de los Lores (House of Lords), cumpliendo su función de tribunal superior, reafirmó que un jurado puede legalmente imputar el cargo de conspiración para corromper la moral pública, en el caso de la oferta publicitaria por personas, de su disponibilidad (nocomercial) para actos homosexuales. ${ }^{1}$ La Corte de Apelaciones ha reafirmado de manera constante, particularmente en 1977, 1981 y $1990,{ }^{2}$ que las solicitudes públicas de hombres adultos por otros hombres adultos caen dentro de la prohibición estatutaria de "importunar con fines inmorales en un lugar público". ${ }^{3} \mathrm{El}$ Parlamento ha aceptado pacíficamente ambas interpretaciones judiciales acerca de la posición de la ley constitucional, estatutaria y del common law. También ha votado más de una vez, con el objeto de mantener la posición legal por la que se sostiene que la edad del consentimiento para las relaciones sexuales aceptadas por la ley es de 21 años para las homosexuales y de 16 para el trato heterosexua 1;4 en febrero de 1994, la Cámara de los Comunes (House of Commons) votó para establecer la edad del consentimiento homosexual a los 18 años, lo que reduciría - pero a la vez mantendría - la diferencia entre la conducta homosexual y la heterosexual. ${ }^{5}$ En 1988, el Parlamento prohibió específicamente a los gobiernos locales de Inglaterra hacer cualquier cosa dirigida a "promover intencionalmente la homosexualidad" o que "promoviese la enseñanza, en escuelas oficiales, de que la homosexualidad es aceptable como una pretendida relación familiar". ${ }^{6}$

1 Knuller (Publishing, Printing and Promotions) Ltd. v. Director of Pub. Prosecutions, [1973] A.C 435 (1972).

2 Regina v. Goddard, Crim App. R 185 (1990); Regina v. Gray, 74 Crim App. R 324 (1981); Regina v. Ford, 66 Crim App. R 46 (1977).

3 Sexual Offences Act, 1956, 4 \& 5 Eliz., 2, ch. 69 y 32 (Inglaterra).

4 lbidem, § 6 (1) (actos heterosexuales: edad de consentimiento 16 años); Sexual Offences Act, 1967, cap. 60, § 1 (1) (Inglaterra) (actos homosexuales: edad de consentimiento 21 años).

5 El proyecto de ley debe, aún, ser aprobado por la Cámara de los Lores.

6 El estatuto establece:

“2A (1) Una autoridad local no podrá: 
Las provisiones de la ley inglesa relativas al matrimonio y a la adopción manifiestan, de manera similar, un propósito, o al menos un deseo, de desalentar la conducta homosexual e impedir su promoción por cualquier forma de actividad que invite a ella, salvo la de los adultos que hubieran prestado su consentimiento, y en un ambiente completamente privado.

La posición inglesa descrita supra guarda total conformidad con la posición sustentada por las instituciones europeas de derechos humanos. Cuando la Corte Europea de Derechos Humanos, en 1981, adoptó (y reafirmó en 1988) la posición que el Parlamento de Inglaterra había tomado en 1967, determinó que la prohibición penal de la actividad homosexual privada entre adultos no era necesaria para asegurar el legítimo objetivo del Estado de tutelar la moral. ${ }^{7}$ Con esto, la Corte dejó expresamente incólume, y en principio, confirmada, la decisión de la Comisión Europea de Derechos Humanos del 13 de marzo de 1980 (y de la Comisión del 12 de octubre de 1978 y del Consejo de Ministros, por resolución DH [79] 5 del 12 de junio de 1979) de que los Estados pueden prohibir actos homosexuales consensuales que involucren a un hombre menor de 21 años, no obstante el derecho de no discriminación en la protección legal de los derechos reconocidos en la Convención, y a pesar de que la ley inglesa a la que nos referimos establece que la "edad para el consentimiento" será de 16 años para la relación heterosexual (y de 18 para otros propósitos).

(a) promover intencionalmente la homosexualidad o publicar materiales con intención de promover la homosexualidad;

(b) promover la enseñanza, en cualquier escuela mantenida, de la aceptación de la homosexualidad como una pretendida relación familiar".

Local Government Act, 1986, cap. 1O, § 2A (Inglaterra), insertado por el Local Government Act, 1988, cap. 9, § 28 (Inglaterra).

Una "escuela mantenida" es cualquier escuela cuyos fondos provienen de una autoridad gubernamental local, lo que incluye a la mayoría de las escuelas de Inglaterra.

7 Dudgeon v. United Kingdom, 45 Eur. Ct .H.R. 21 (ser.A) (1981); Norris v. Ireland, 142 Eur. Ct. H.R. 20 (ser.A) (1988). 
Posteriormente, la Comisión reafirmó esa decisión y declaró inaudibles ("inadmisible" para procesos jurídicos posteriores) las quejas formuladas bajo las cláusulas antidiscriminatorias de la Convención, contra la ley suiza, de larga data, que considera acto criminal a la prostitución homosexual (hombres o mujeres) pero no a la prostitución heterosexual. ${ }^{8}$

II. La posición [europea] moderna predominante está de acuerdo con quienes opinan que (tal vez con excepción de algunos casos y contextos especiales) sería injusto que A impusiera cualquier desventaja sobre B, simplemente porque A cree (a lo mejor correctamente) que B tiene inclinaciones sexuales (sobre las que puede o no actuar) hacia personas del mismo sexo (casos especiales suelen surgir más comúnmente, por ejemplo, donde la inclinación de B es hacia un "amor de hombre a niño", es decir, pederastia). La posición no da a B la más amplia protección legal concebible contra tan injusta discriminación (como tampoco la da contra actos privados innecesarios de discriminación en la locación para vivienda o empleo de personas con opiniones políticas poco populares o excéntricas). Pero la posición en sí no fomenta, patrocina o impone semejante carga injusta (y está acompañada de muchas protecciones legales para personas homosexuales en lo que respecta a asaltos, amenazas, discriminación irrazonable por instituciones u oficiales públicos, etcétera).

El interés de la posición moderna predominante, en sí misma, no es en inclinaciones, sino solamente en ciertas decisiones de expresar o manifestar la deliberada promoción de - o el ánimo de involucrarse en - actividades o conductas homosexuales, incluyendo la promoción de formas de vida (por ejemplo la cohabitación alegadamente marital), que a su vez incitan a tales actividades y las presentan como una alternativa válida o aceptable a la unión heterosexual, que el Estado reconoce como matrimonio. Las leyes estaduales y las políticas estaduales que ya he señalado, suje-

8 Solicitud 11680/85, decisión del 10 de marzo de 1988, inédita; véase Delmas-Marty, Mireille, The European Convention for the protection of Human Rights: International protection versus National restrictions, 1992, 253-54. 
tas solamente al requisito constitucional (explícito o implícito) de libertad para la discusión de ideas, pretenden desalentar decisiones deliberadamente orientadas hacia la conducta homosexual y manifestadas públicamente.

La posición moderna predominante difiere de la posición a la que ha reemplazado, la cual considera a la sodomía consensual entre adultos, y actos semejantes, crímenes per se. Los Estados que se adhieren a la posición moderna predominante dejan claro por medio de leyes y políticas, como aquellas a las que he hecho referencia, que el Estado de ninguna manera ha renunciado a su legítimo interés en la moral pública y en la educación tanto de los niños como de los jóvenes, orientada hacia lo que es realmente valioso y contra las formas de conducta y de vida tentadoras pero malas. Ni han renunciado dichos Estados al juicio de que una vida envuelta en conductas homosexuales es mala, incluso para quien haya sido tan desafortunado como para tener inclinaciones innatas o cuasi-innatas hacia la homosexualidad.

La diferencia entre la posición moderna predominante y la posición a la que ha reemplazado se puede expresar de la siguiente manera. La posición moderna predominante considera que la responsabilidad del Estado de sostener los verdaderos valores (moralidad) es una responsabilidad subsidiaria (auxiliar) a la responsabilidad primaria de los padres y de las asociaciones voluntarias, no políticas. El papel subsidiario del gobierno está ampliamente enfatizado y cada vez más aceptado, por lo menos en principio, en la política europea contemporánea (fue, por ejemplo, una de las piedras angulares del Tratado de Maastricht de 1992). Esta concepción del rol gubernamental ha sido tomada para excluir al Estado de la asunción de un rol directamente paternalista y disciplinario, sobre adultos capaces de prestar su propio consentimiento. Ese era el rol que la teoría y praxis política atribuía anteriormente al Estado en la convicción de que surgía por una necesidad lógica, de la realidad de que el Estado debía estimular los verdaderos valores y desalentar la inmoralidad. Esta 
convicción se juzga ahora equivocada (juicio que defenderé en la parte final de este ensayo).

De esta manera, la teoría y práctica moderna traza una distinción que no aparece en las anteriores disposiciones legales, una distinción entre: a) la supervisión de la conducta verdaderamente privada de los adultos, y b) la supervisión del dominio o ámbito público. La importancia de este último incluye las siguientes consideraciones: (1) éste es el ámbito o dominio público en que la juventud (de cualquier inclinación sexual) es educada; (2) es el contexto en el que y por el que todos los que tienen responsabilidad sobre el bienestar de la gente joven son ayudados o impedidos de asistirlos para que eviten formas de vida malas; (3) es el medio en el cual y por el cual todos los ciudadanos son alentados y ayudados, o desalentados y socavados, en su propia resistencia a ser atraídos por tentaciones que los alejan de sus aspiraciones a ser personas de carácter íntegro y a ser personas autónomas, capaces de controlarse, en lugar de esclavos del impulso y la gratificación por los sentidos.

Mientras que el tipo (a) de supervisión de las conductas verdaderamente privadas de los adultos es considerada fuera del rol normalmente propio del Estado (con excepción del daño sobre el cuerpo en el sado-masoquismo y la asistencia en el suicidio), el tipo (b) de supervisión del ambiente moral-cultural-educacional se mantiene como parte muy importante de la justificación del Estado para exigir legítimamente la fidelidad de sus ciudadanos decentes.

III. La posición moderna predominante es parte de un orden político-legal que sistemáticamente proscribe muchas formas de discriminación. Es así como la Convención Europea sobre Derechos Humanos (modelo para docenas de Constituciones promulgadas en los últimos treinta y cinco años por las autoridades británicas, para las naciones que obtenían su independencia) estipula que la protección de los derechos que ella establece debe ser aprovechada sin discriminación de ninguna índole, como son "sexo, raza, color, lengua, religión, opinión política o de otra ín- 
dole, origen nacional o social, asociación con una minoría nacional, propiedad, nacimiento u otro status".

Pero la posición moderna predominante deliberadamente rechaza propuestas de incluir en dichas listas el ítem "orientación sexual". La explicación dada comúnmente (correcta en mi opinión) es ésta: la frase "orientación sexual" es radicalmente equívoca. Particularmente, cuando es utilizada por los promotores de los "derechos de los gays", la frase ambiguamente asimila dos cosas que la posición moderna predominante distingue cuidadosamente: (I) una disposición psicológica o psicosomática que orienta interiormente hacia la actividad homosexual; (II) la deliberada decisión de orientar el propio comportamiento público para expresar o manifestar el propio interés activo y el respaldo de la conducta homosexual y/o formas de vida que presumiblemente involucran dicha conducta.

Se ha observado que las leyes y proyectos que proscriben "la discriminación basada en la orientación sexual" son interpretadas por los movimientos "pro-derechos de los gays" en forma más amplia que la discriminación consistente en la mera creencia de A en que B es atraído sexualmente por personas del mismo sexo. En ocasiones (se ha observado), los movimientos de "derechos de los gays" lo interpretan como una protección legal extendida a las actividades públicas con intenciones específicas de promover, procurar y facilitar la conducta homosexual.

En círculos públicos europeos se ha notado que dichas leyes han sido interpretadas por cortes norteamericanas con ese alcance. Un ejemplo que ha sido ampliamente difundido es el del caso Universidad de Georgetown, ${ }^{9}$ donde se pidió a un instituto educacional confesional que diera acceso equitativo a sus instalaciones a organizaciones "que participan en, y promueven estilos de vida homosexual [los que necesariamente incluyen conductas homosexuales]" en manifiesta oposición a las creencias

9 Centro de Derecho de la Coalición de los Derechos de los Gays de la Universidad de Georgetown. v. Georgetown Univ., 536 A.2d 1 (D.C 1987). 
y enseñanzas morales de la religión con la que dicha institución estaba asociada.

Así, aunque la posición predominante acepta que los actos de discriminación del tipo (I) son injustos, juzga que hay razones de peso tanto para negar que tal injusticia pudiera ser apropiadamente remediada por medio de leyes contra "la discriminación basada en la orientación sexual", como para sostener que tal "remedio" daría como resultado la discriminación, y la injusticia (e incluso el daño) contra las familias, asociaciones e instituciones que se han organizado para vivir y trasmitir ideales de vida familiar que incluyen una concepción elevada del valor de las genuinas relaciones sexuales conyugales.

De hecho, es aceptado por casi todos en ambos lados del debate político, que la adopción de una ley destinada a la prohibición de la "discriminación en el campo de la orientación sexual" requeriría el pronto abandono de todos los intentos de la comunidad política por desalentar la conducta homosexual por medio de una política educativa, de restricciones a la prostitución, del no reconocimiento de "matrimonios" homosexuales o adopciones por parejas homosexuales, etcétera. Se juzga (rectamente, desde mi punto de vista) que la ley, por fuerza, pasaría de enseñar de distintas maneras que la conducta homosexual es mala, a enseñar de manera masiva que es un tipo de actividad sexual tan bueno como cualquier otro (y per se, mucho menos cargado de responsabilidades onerosas que la unión sexual del marido y la mujer o, tal vez, de distinta manera, que la vida de aquellos que viven en soltera castidad).

IV. La posición moderna predominante encierra varios juicios, explícitos o implícitos, sobre la función propia de la ley y los intereses relevantes de las comunidades políticas, y sobre la maldad de la conducta homosexual. ¿Pueden estos juicios ser defendidos con argumentos reflexivos, críticos, públicamente inteligibles y racionales? Creo que sí. Como ni aun defensores de los "derechos de los gays" sostienen seriamente que el Estado nunca puede tener interés en la moral pública o en la formación 
moral de su juventud, o en el ambiente moral en que los padres, otros educadores y la misma juventud, deben desarrollar esta formación, en este ensayo pondré énfasis, ante todo, en el tema de fondo que recibe poca discusión pública: ¿qué hay de malo en la conducta homosexual? ¿Su juicio como moralmente mala es invariablemente una manifestación de mera hostilidad hacia una minoría odiada, o una creencia religiosa, teológica y sectaria que no puede servir de fundamento para una determinación constitucionalmente válida que ponga en desventaja a aquellos que no se ajustan a ella?

He usado y continuaré usando indistintamente los términos "actividad homosexual", "actos homosexuales" y "conducta homosexual" para referirme a los actos corporales sobre una persona del mismo sexo, realizados con el fin de asegurar la satisfacción sexual orgásmica de una o más partes.

Permítanme comenzar por destacar un dato poco conocido. Los tres filósofos griegos más importantes, Sócrates, Platón y Aristóteles, consideraban a la conducta homosexual como intrínsecamente vergonzosa, inmoral y ciertamente depravada o depravante. Es decir, los tres rechazaban la parte esencial de la ideología "gay" moderna y su estilo de vida.

Sócrates es retratado por Platón (y por Xenofonte) con fuertes inclinaciones o intereses homosexuales (como también heterosexuales) y promoviendo un ideal de romance homosexual entre hombres y jóvenes, pero, al mismo tiempo, rechazando cabalmente la conducta homosexual. Esto aparece claramente en el libro de Sir Keneth Dover, Greek Homosexuality. ${ }^{10}$ En las palabras sintetizadoras de Dover: "El Sócrates de Xenofón carece de la sensualidad y la urbanidad del Sócrates platónico, pero no hay duda de que ambos condenan la cópula homosexual". ${ }^{11}$ También está aclarado por Gregory Vlastos en su último libro, precisamente sobre Sócrates: en el eros socrático que involucra relaciones de afecto entre hombres y niños o jóvenes, la intimidad está limitada al

10 Dover, Kenneth Y., Greek homosexuality, 1978, 154-59.

11 Ibidem, 159. 
contacto intelectual y visual, la "gratificación terminal" está prohibida $^{12}$ (y a fortiori en las relaciones entre varones adultos, ya que virtualmente todos los atenienses consideraban los actos sexuales entre hombres adultos como intrínsecamente vergonzosos). ${ }^{13}$ Así es como Vlastos aclara que Sócrates prohíbe precisamente lo que yo he estado denominando conducta homosexual.

En el reciente caso sobre la segunda enmienda en Colorado, Evans v. Romer, ${ }^{14}$ la profesora Martha Nussbaum, filósofa clásica de gran influencia, presentó evidencia oral y escrita sobre estas materias como testigo experto de parte de los demandantes, quienes buscan derogar una disposición de la Constitución de Colorado que establece que ningún organismo oficial de Colorado puede adoptar una ley o política "en virtud de la cual la orientación, conducta, práctica o relación homosexual, lesbiana o bisexual pueda constituir o de cualquier modo servir de base para... un reclamo de status minoritario, cuotas preferenciales, status protegido o reclamo por discriminación". En su testimonio oral (el 15 de octubre de 1993) negó drásticamente que el libro de Dover, Greek Homosexuality, llegara a la conclusión de que Sócrates condenaba la cópula homosexual. Nussbaum sostuvo que Dover solamente afirmaba que Sócrates condenaba la seducción de estudiantes. Unos días después, el profesor Robert George, profesor e investigador de teoría legal y política en Princeton, presentó evidencia para demostrar que el libro de Dover inequívocamente concluye que Sócrates, retratado por nuestras dos fuentes, Platón y Xenofonte, condenaba la cópula homosexual como tal y no confinaba la prohibición a ninguna relación en particular. La profesora Nussbaum escribió prontamente ${ }^{15}$ a George aseguran-

12 Vlastos, Gregory, Socrates, ironist and moral philosopher, 1991, 38-39.

13 Hindley, Clifford y Cohen, David, "Debate: Law, Society and Homosexuality in Classical Athens", 133 Past E Present, 1991, 167, 179-80, 188 n. 14.

14 Núm. 92CV7223 (D. Den., archivada el 12 de noviembre de 1992).

15 Carta de Martha Nussbaum, profesora de filosofía y clásicos, Brown University (20 de octubre de 1993). La carta fue enviada por fax el 21 de octubre de 1993. 
do que eso era falso testimonio, dado en una temeraria desatención a la verdad. Solicitando perentoriamente que George se retractara antes de la clausura del juicio el 22 de octubre de 1993, dijo que el mismo Dover apoyaría personalmente la lectura de su conclusión sobre Sócrates. En esa oportunidad, Dover me escribió el 23 de enero de 1994, y me autorizó a citarlo: "Ciertamente es mi opinión que el Sócrates de Platón y de Xenofonte, condenaba la cópula homosexual como tal y no limitaba la prohibición a ninguna relación particular. Ciertamente he querido decir eso en la página 159 de mi libro". ${ }^{16}$

¿Entonces, qué hay de Platón? Bueno, el mismo Platón, que escribiera en su Banquete una famosa celebración de las relaciones eróticas, románticas y espirituales de hombre a niño, puso muy en claro que todas las formas de conducta sexual fuera del matrimonio heterosexual son vergonzosas, malas y nocivas. Esto es particularmente evidente en el tratamiento que le da a este asunto en su último trabajo, Las leyes, pero también está lo suficientemente claro en La República y en Fedro, e incluso en el mismo Banquete. Esto está inequívocamente afirmado por Dover y Vlastos, ambos en desacuerdo con estas opiniones de Platón. Según Vlastos, por ejemplo, Platón "veía la relación anal como «contraria a la naturaleza» [nota al pie de pág.: Fedro 251A1, L[eyes] 636-7] una degradación no solamente de la humanidad del hombre, sino incluso de su animalidad....". ${ }^{17}$

16 Carta de Kenneth J. Dover (25 de enero de 1994) (en el archivo del autor).

17 Vlastos, Gregory, Platonic-studies, 25, 2a. ed., 1981. En la nota al pie, Vlastos se queja de que por para phusin, "contrario a la naturaleza", Platón, aquí y en 836 A-C, quería decir algo "más fuerte" que la frase "contra las leyes" usada por Dover en su artículo de 1966 sobre el eros y el nomos. Antes de la edición revisada, Vlastos y Dover intercambiaron correspondencia sobre esta observación y Vlastos cita una carta de Dover:

Lo que Platón efectivamente creía era que el acto era "anti-natural", en el sentido de "contra las reglas"; que era una explotación moralmente ignorante del placer, más allá de lo "dado" (kata phnusin apodedosthei [Leyes], 634 c 4), que era el producto de una akrateia ([636] C6), que puede ser agravada por el hábito 
Añade Vlastos que es para Platón un tipo de acto mucho más serio que el mero hecho de ir "contra las reglas". ${ }^{18}$

La evidencia oral de Martha Nussbaum acerca de Platón siguió un curso notable. Ella afirmaba que la traducción de Las leyes, 636, ${ }^{19}$ que había sido citada en mi testimonio ante el tribunal, era inexacta; en vez de la frase: "aquellos culpables de tal enormidad", se debía leer en términos moralmente neutros, "aquellos que primero se aventuraron a hacer estas cosas". Por lo tanto, no se podía confiar en ninguna de las traducciones o las referencias a Platón de mi testimonio, y Platón, de hecho, aprobaba la conducta homosexual. Entonces Robert George presentó evidencia mostrando que todas las traducciones al inglés existentes, sin excepción, traducen la frase griega "pertinente" con algún término peyorativo o usan un término peyorativo sobre esa misma conducta en un punto equivalente de la oración previa, y que en particular el filólogo Sir Kenneth Dover traduce la palabra griega relevante tolmema como "crimen" (refiriéndose al crimen moral). Así es que en su testimonio, el último día del juicio, la profesora Nussbaum declaró que Liddell y Scott, "el diccionario griego autorizado, en el que confian todos los estudiosos de esta área", traduce tolmema sólo con términos favo-

y el mal ejemplo. Su comparación de la homosexualidad con el incesto ([Leyes] 837E8-838E1) es particularmente reveladora.

Ibidem, 424. Vlastos inmediatamente hace notar que la alusión de Dover a la comparación platónica de la homosexualidad con el incesto demuestra que Dover reconoce la gran fuerza con que Platón está condenando lo que Vlastos llamaba "relación anal" y Dover, más holgadamente, "el acto y la homosexualidad". Ibidem, 25, 424.

18 Ibidem, 25. Yo deseo agregar, por respeto a Platón, que el valioso libro de Anthony Price rechaza firmemente la teoría de Vlastos de que Sócrates y Platón, aunque prohibieran los actos homosexuales, aceptaban que los amantes pudieran endilgarse, no obstante las caricias de las que se habla en Fedro, 255e. Price, Anthony W., Love and friendship in Plato and Aristotle, 1989, 89-94.

19 "When male unites with female for procreation the pleasure experienced is held to be natural, but unnatural when male mates with male or female with female, and those first guilty of these enormities were impelled by their weakness for pleasure"; Platón, Las leyes, trad. de R.G. Bury, 1926, I, 636c en 41. 
rables o neutros: "una aventura, empresa, acción de osadía". ${ }^{20}$ Sin embargo, de hecho, Liddell y Scott lo traduce como "aventura, empresa, acto desvergonzado o atrevido". ${ }^{21}$ Lo que hizo Nussbaum fue citar la edición de 1897, una edición enteramente reemplazada en 1940, sin revelar al tribunal su fecha o su edición. En suma, presentó un diccionario ante el tribunal precisamente como "el diccionario autorizado, en el que confían todos los estudiosos de esta área", pero la cita que ella dijo haber tomado de ese diccionario era, de hecho, de un diccionario que ni es autorizado ni en el cual confía estudioso alguno. Y lo hizo porque de haber citado el verdadero "diccionario autorizado" habría destruido el principal argumento de su testimonio oral sobre Platón, mientras que si hubiese permitido al tribunal conocer la verdad sobre la fuente decimonónica y obsoleta de su lexicografía, habría privado a su testimonio del aparente sostén autorizado que tanto necesitaba para contrarrestar el devastador testimonio opositor de Dover.

En su testimonio oral, ella negó de lleno que el estudio de Dover sobre Platón llegara a la conclusión de que este último condenaba toda cópula homosexual. No, dijo, Dover sólo concluyó que Platón condenaba el sexo relacionado con el soborno o la prostitución. Una vez más, Dover, enterado de dicha argumentación, me permite citar su carta del 23 de enero de 1994: "Platón condena toda cópula homosexual (pp. 165-8 en mi libro)". 22

Un elemento clave para la condena de la conducta homosexual, por parte de Platón, es su repetido juicio, en Fedro y en Las leyes, de que es para phusin, o sea contrario a la naturaleza. Sobre este tema, el testimonio de la profesora Nussbaum fue claro:

20 Testimonio de Martha Nussbaum, fs. 10, Evans v. Romer. Nro. 92CV7223 (D. Den, archivado el 12 de noviembre de 1992) (21 de octubre de 1993) (dado el 22 de octubre de 1993).

21 Llddell-Scott, A Greek-English lexicon, 1803 (Sir Henry Stuart Jones y Roderick Mc Kenzie, editores, 9a. ed., 1940, sup. 1968) (1992).

22 Dover, nota 16 supra. 
los términos traducidos tendenciosamente como "de acuerdo con la naturaleza" y "contranatural" o "contrario a la naturaleza" se refieren en realidad (según mi experta opinión y el consenso de recientes autores, como Price, cuyo estudio del pasaje [en Las Leyes] ha sido ampliamente aceptado), a "nacimiento" y no a "naturaleza" en ningún sentido moralmente normativo. ${ }^{23}$

La pretensión de que existe un consenso entre los autores contemporáneos, quienes rechazarían por tendenciosa la traducción "anti-natural" o "contrario a la naturaleza" o que apoyarían la extravagante traducción de para phusin realizada por Nussbaum, fue una fábula pura. Según Nussbaum misma, el "consenso moderno" sobre la materia se formó alrededor del estudio "ampliamente aceptado" de Price. Muy bien. Pero lo que dice Nussbaum sobre el estudio de Price del pasaje en cuestión es, sorprendentemente, la contracara exacta de la verdad. Ese estudio traduce sin titubeos a para phusin, en Las leyes, ns. 636 y 841, como "antinatural". Por ejemplo, su traducción del n. 636c

23 Supra, nota de Nussbaum nro. 20 a fs. 54. Este "consenso de los recientes autores, como Price", se transforma en la primera frase del párrafo siguiente en "el consenso moderno". Una referencia anterior aclara que la referencia al estudio del pasaje "ampliamente aceptado", de Price, pertenece a su libro: Love and friendship in Plato and Aristotle, supra nota 18. El libro fue reseñado por la profesora Nussbaum en el Times Literary Supplement de febrero de 1990. A lo largo de su disertación sobre Las leyes a fs. 51-55, Nussbaum se refiere al "pasaje" sin identificarlo nunca o prestar atención al hecho de que en mi declaración, del 8 de octubre de 1993, yo había hecho referencia a cuatro pasajes, y citado textualmente dos pasajes de partes distintas del libro de Platón, cada uno de los cuales aplica a los actos homosexuales, la frase que ella comenta a fs. 54: para phusin. El único pasaje que ella ha citado explícitamente ante el tribunal es el de Las leyes, n. 636, libro I, pero algunos comentarios confusos a fs. 52 y la línea argumental de fs. 54, sugieren que ha de haber tenido en mente, sobre todo, Las leyes, VIII, n. 841 a fs. 54. No se debería pasar por alto que la discordancia entre "actos homosexuales" y phusis está afirmada plenamente por Platón en Las leyes, VIII, ns. 836 y 838 . 
es: "la relación homosexual, entre hombres o mujeres, parece ser un crimen [tolmema] antinatural [para phusin] de primer grado". ${ }^{24}$

Permítanme resumir cómo trató la profesora Nussbaum al estudio "ampliamente aceptado" de Price. El libro de Price traduce estos usos de para phusin como "antinatural", y aun encontrándose bajo juramento, las declaraciones de Nussbaum implican sin vacilación que Price, rechaza esa traducción por tendenciosa. Las conclusiones del largo apéndice sobre "La moralidad sexual de Platón", del libro de Price están firmemente basadas en su razonado juicio de que la palabra "antinatural" en estos pasajes da a entender y transmite los juicios morales esenciales de Platón sobre la conducta sexual; e igualmente Nussbaum jura que eso sirve de fundamento a su negativa de que el término tuviera "ningún sentido moral normativo", y a su argumento de que para Platón significaba una mera incompatibilidad con la política colonial pro natalista de la época. Nussbaum implícitamente sostiene que el libro de Price apoya su argumento fundamental de que la moralidad sexual expuesta al tribunal por Robert George y por mí es puramente teológica, católica e incluso estrictamente tomista en su origen, y "simplemente no tiene precedentes en los ejemplares seculares de argumentación basada en ley natural de la antigua Grecia", ${ }^{25}$ incluyendo a Platón; ${ }^{26}$ sin embargo, el libro de Price, de hecho, sostiene de manera saliente y explícita que la posición principal de Platón sobre moralidad en la conducta sexual, puesta en evidencia en La República y Fedro, como también en Las leyes, era (mal que le pesara a Price) sustancialmente la misma que la sostenida por la tradición católica en su comprensión de la ley natural. ${ }^{27}$

La invención del imaginario consenso moderno sobre el término para phusin también obligó a la profesora Nussbaum a ocul-

24 Price, supra nota 18, en 230.

25 Nussbaum, supra nota 20 a fs. 14.

26 Ibidem, a fs. 67.

27 Price, supra nota 18, en 229-235 (nótense las referencias a Pablo VI y a Juan Pablo II en 233-235). 
tar al tribunal el hecho de que las demás autoridades académicas citadas profusamente en su testimonio - Dover, Price, Vlastos, Winkler - coinciden todas en usar los términos "antinatural" o "contrario a la naturaleza" para traducir para phusin en Las leyes, cuando el término se refiere a actos homosexuales. ${ }^{28}$ Todos tratan esta traducción como enteramente carente de controversias. Todos juzgan que para phusin, utilizada así por Platón en Las leyes, debe ser entendida como el núcleo de una condena firme y sin atenuantes a la conducta homosexual. Todos rechazan, explícita o implícitamente, la aseveración de Nussbaum de que "el pasaje" de Las leyes "no dice nada sobre actos sexuales entre gente soltera". Como incluso Halperin y Winkler (los académicos abiertamente "gay" a los que Nussbaum recurre en su declaración), tanto Dover como Price, y (como veremos) Vlastos, juzgan que para saber o hablar acerca de las opiniones de Platón acerca de la moralidad o la inmoralidad de todas las conductas no maritales, como los actos homosexuales, no se necesita más que ir a estos inconfundibles pasajes en Las leyes, textos compatibles con cualquier otro texto de Platón. ${ }^{29}$

En cuanto a Aristóteles, la discusión de Dover es menos satisfactoria; olvida un buen número de pasajes relevantes, a pesar de lo cual no contradice el consenso académico acerca del rechazo de Aristóteles a la conducta homosexual. De hecho, dicha conducta es frecuentemente representada por Aristóteles (en algunos casos abiertamente y en otros mediante pistas) como intrínsecamente perversa, vergonzosa y lesiva, tanto para los individuos involucrados en ella como para toda la sociedad. ${ }^{30}$

Sobre Aristóteles, las manipulaciones en la declaración de Nussbaum fueron tan profundas como a esta altura deberíamos

28 Dover, supra nota 10, en 165-68, Vlastos, supra nota 17, en 25, 425; Winkler, John J., The constraints of desire, 18, 21 N (1990).

29 Véase Halperin, David M., One hundred years of homosexuality, 1990, 91; Winkler, supra nota 28, en 18, 21.

30 Véase Aristóteles, Ética Nicomaquea, VII 5: 1148 b 29. Aristóteles, Política, II 1:1252a 33-39, junto con las insinuaciones en II 6: 1269b 28 y II, 7: 1272a 25. 
esperar. Nussbaum asoció el libro de Price con la aseveración de su declaración en la que sostenía que Aristóteles apoyaba y aprobaba los actos homosexuales. Pero en realidad el Aristóteles del libro de Price está "bastante atónito" incluso por la cuidadosa y restringida sugerencia de La República de Platón acerca de que "el amante puede besar y tocar al amado, con su consentimiento, como a un hijo". ${ }^{31}$ Las oraciones finales de las reflexiones de Price sobre la visión aristotélica del amor erótico concluyen que, para Aristóteles, dicho amor es propiamente marital o pederástico; en la misma página, Price nos recuerda que para Aristóteles la pederastia no sólo es tan transitoria como la niñez, sino que además debería ceñirse a sus formas más elevadas, "mirando más que amando" como Platón ya lo había dicho. ${ }^{32}$ No se incluyen los actos homosexuales. ¿Qué encontramos en los dichos de Nussbaum? "Estoy de acuerdo con la conclusión de Price", dice, citando la oraciones finales de Price, pero cortando sin indicación alguna las primeras catorce palabras para que en lugar de la referencia de Price al matrimonio y la pederastia (entendida como excluyendo los actos sexuales), las pueda sustituir por sus propias palabras, "relaciones heterosexuales y homosexuales" (entendidas como incluyendo actos sexuales entre hombres de cualquier edad). Una distorsión falsificadora similar ocurre la única vez que cita directamente a Aristóteles, y todos los otros pasajes de Aristóteles que ella cita han sido manifiestamente abusados y mal representados.

A pesar de que la ideología del amor homosexual (con su consecuente degradación de la mujer) continuó teniendo defensores filosóficos hasta el final de la civilización griega clásica, también continuó habiendo importantes escritores filosóficos, absolutamente ajenos a la tradición judeo-cristiana, que enseñaban que la conducta homosexual no sólo es intrínsecamente vergonzosa, sino que también es inconsistente con el reconocimien-

31 Price, supra nota 18, en 224-25 (citando a Platón, La República, 403b 4-6, y Aristóteles, Política, 1262a 32-7).

32 Ibidem (citando a Platón, Las leyes, VIII 837 [4-5]). 
to de la igualdad del hombre y la mujer en su valor intrínseco (los antiguos no fallaron en notar que la orientación homoerótica de Sócrates, aunque admirable por su castidad — abstención de incurrir en conductas homosexuales-, iba acompañada por la negativa de tratar a su esposa como una igual). Un buen ejemplo de dichos escritos es el Erotikos de Plutarco, ${ }^{33}$ escrito probablemente a principios del siglo segundo, pero ciertamente libre de influencia judeo-cristiana. Su vasto corpus de escritos literariohistóricos y filosóficos es un esfuerzo de volver a capturar y recapitular los más altos logros de la civilización clásica, y tuvo una influencia muy significativa en el pensamiento occidental hasta tiempos recientes. Me referiré al pensamiento de Plutarco sobre estos temas más adelante.

Otro ejemplo es el del estoico Musonio Rufo (quien enseñó en Roma alrededor del 80 d. C. y no fue influido por el pensamiento judío o cristiano). Musonio Rufo rechaza toda conducta homosexual como vergonzosa. La conducta sexual es aceptable y decente sólo dentro del ámbito del matrimonio. El objetivo de dicha institución no sólo incluye la procreación y la crianza de los niños, sino también, integral y esencialmente, una completa comunidad de vida, cuidado mutuo y afecto entre los esposos. ${ }^{34}$

En el corazón de los rechazos platónicos, aristotélicos y del resto de los antiguos al amor homosexual, y por ende a la ideología "gay" moderna, hay tres tesis fundamentales: (1) el compromiso del hombre y la mujer en la unión sexual del matrimonio es intrínsecamente bueno y razonable, y es incompatible con las relaciones sexuales fuera del matrimonio; (2) los actos homosexuales son radical y peculiarmente no matrimoniales, y por esa razón intrínsecamente irrazonables y antinaturales; (3) más aún, según Platón, si no Aristóteles, los actos homosexuales tienen una especial similitud con la masturbación solitaria, y ambos tipos de acto no-matrimonial son manifiestamente indignos del hombre e inmorales.

33 Plutarco, Erotikos, Diálogo sobre el amor, 751 c-d,766-e 771-d.

34 Musonius Rufus, Discursos, VII y VIII a. en Lutz, Cora E., "Musonius Rufus, «the Roman Socrates»", Yale classical studies, 1947, X, 85-89. 
V. Quiero ofrecer ahora una interpretación de estas tres tesis que las articula de manera más clara que la que intentaran Platón o, hasta donde se sabe, Aristóteles. Es, pienso, una interpretación fiel de lo que ellos dicen, pero toma sugerencias de Plutarco y del iluminismo de Kant (quien también rechazaba la conducta homosexual), a pesar de que incluso las indicaciones de estos escritores permanecen sucintas. Mi interpretación también articula pensamientos que históricamente han estado implícitos en los juicios de muchos no filósofos, y que se han sostenido para justificar las leyes adoptadas en muchas naciones y Estados, antes y después de que las creencias cristianas fueran política y socialmente dominantes. Y es una aplicación de la teoría de la moralidad y ley natural desarrollada en los últimos treinta años por Germain Grisez y otros. Una exposición más completa puede encontrarse en el capítulo sobre matrimonio, actos sexuales y vida familiar en el nuevo volumen II de la gran obra de Grisez sobre teología moral. ${ }^{35}$

La preocupación de Platón, en Las leyes, por la familiaridad, el afecto y el amor entre los esposos en un matrimonio casto, la representación de Aristóteles del matrimonio como una amistad intrínsecamente deseable entre cuasi-iguales, y como un estado de vida aun más natural a los seres humanos que la vida política, ${ }^{36}$ y la concepción de Musonio Rufo de los doble-bienes inseparables del matrimonio, encuentran expresión en la celebración que hace Plutarco del matrimonio - como una unión que no es puramente instintiva, sino que es un amor razonable, y no solamente para la procreación, sino también para la ayuda mutua, la buena voluntad y la cooperación en sí mismas-. ${ }^{37}$ Las severas críticas

35 Grisez, Germain, The way of the lord fesus, Living a Christian Life, 1993, 555574, 633-680.

36 Aristóteles, Ética nicomaquea, VIII, 12: 1162a 16-30. Véase también el probablemente pseudo-Aristóteles, Oeconomica, I, 3-4; 1343b, 121344 a 22; III.

37 Plutarco detecta este concepto ya en los albores de la civilización ateniense, y, sin duda, anacrónicamente lo atribuye al gran legislador original de Atenas, Solón: el matrimonio debería ser "una unión de vida, entre el hombre y la mujer, para los placeres del amor y la procreación de los hijos". Plutarco, 
que hace Plutarco a la conducta homosexual (y al menosprecio por las mujeres implícito en la ideología homosexual ${ }^{38}$ son un desarrollo de las críticas que hace Platón a la conducta homosexual y a toda otra conducta sexual extramatrimonial. Como Musonio Rufo, Plutarco lo hace articulando mucho más explícitamente el siguiente pensamiento. El intercambio genital entre los esposos permite actualizar y experimentar (y de ese modo expresar) su matrimonio en sí como una única realidad con dos bendiciones (los hijos y el afecto mutuo). ${ }^{39} \mathrm{El}$ coito no marital, especial pero no únicamente el homosexual, no tiene tal objetivo y es por ende inaceptable.

El núcleo de este argumento puede ser aclarado comparándolo con el tratamiento del matrimonio que hace San Agustín en su De Bono Coniugali. El bien de la comunión marital es aquí un bien instrumental, al servicio de la procreación y la educación de los hijos, de manera que el bien intrínseco, no instrumental de la amistad será promovido y realizado por la propagación de la raza humana, y el bien intrínseco de la integración interna será promovido y realizado por el remedio de los deseos desordenados de la concupiscencia. ${ }^{40}$ Ahora, al considerar los matrimonios

La vida de Solón, 20, 4. Véase también Plutarco, Erotikos, 769. En el caso de las esposas legales, la unión física es el comienzo de la amistad, de alguna manera, un compartir de los grandes misterios. El placer es corto [o sin importancia: Mikron], pero el respeto, el mutuo afecto y la lealtad que diariamente surge de él [sexo conyugal] no condena ni a los Delfos por desvariar cuando ellos llaman "armonía" a Afrodita, ni a Homero cuando designa tal unión como "amistad". También prueba que Solón era un legislador muy experimentado en leyes maritales. Él prescribía que un hombre debía relacionarse con su esposa no menos de tres veces al mes - ciertamente no por el placer, sino que del mismo modo en que las ciudades renuevan sus acuerdos de tiempo en tiempo, así debía desear él que esto fuera una renovación del matrimonio y con tal acto de ternura borrar las quejas que se acumulan en la convivencia diaria-.

38 Véase Plutarco, Erotikos, 768D-770A ; IX Moralia, 427 (Loeb ed. 1961); véase también la espléndida traducción de D. A. Russell, Plutarch, 1973, 92.

39 Plutarco habla de la unión del marido y la mujer como una "amalgama integral” [di' holan krasis]. Plutarco, Erotikos, 769F; Caniugalia praecepta, 142F.

40 San Agustín, De bono coniugali, 9-9. 
estériles, San Agustín había identificado otro bien del matrimonio, la societas natural (compañerismo) de los dos sexos. ${ }^{41}$

Si hubiera realmente integrado esto en su síntesis, habría reconocido que en matrimonios estériles y fértiles por igual, la comunión, compañerismo, societas y amicitia de los esposos - su estar casados - es el bien propio del matrimonio, y es un bien básico, intrínsecamente humano, no meramente instrumental a ningún otro bien. Y esta comunión de vida matrimonial, este amalgamamiento integral de las vidas de dos personas (como lo llamara Plutarco ${ }^{42}$ antes que Juan Pablo II), ${ }^{43}$ tiene como elementos intrínsecos, como partes esenciales del mismo bien único, a los bienes y fines a los que la tradición teológica, después de San Agustín, subordinó dicha comunión. Debió cumplirse un proceso largo y gradual de desarrollo de doctrina, a través del Catecismo del Concilio de Trento, las enseñanzas de Pío XI y Pío XII, y eventualmente aquellas del Concilio Vaticano II - un proceso brillantemente iluminado por Germain Grisez ${ }^{44}$ para traer a la tradición a la posición de que la procreación y los hijos no son ni el fin (primario o secundario) al que el matrimonio sería instrumental (como enseñaba San Agustín), ni que la procreación y los hijos son instrumentos para el bien de los esposos (como supone gran parte del pensamiento "cristiano liberal")—. Más bien, la paternidad, los hijos y la familia son la culminación intrínseca de una comunión que, por no ser meramente instrumental, puede existir y realizar a los esposos incluso si la procreación es imposible para ellos.

Ahora bien, si, como enseña la reciente encíclica sobre los fundamentos de la moral, Veritatis Splendor, "la comunión de personas en el casamiento", violada por cada acto de adulterio, es

41 Ibidem, en 3-3.

42 Plutarco, Erotikos, 769F; Coniugalia praecepta, 1421.

43 Juan Pablo II, "Mensaje a los matrimonios jóvenes en Toronto (octubre 1989)", citado en Grisez, supra nota 35, en 571 n. 46 ("un gran proyecto de fusión de sus personas hasta el punto de llegar a ser un solo cuerpo").

44 Grisez, supra nota 35, en 556-569. 
en sí misma "un bien humano fundamental", ${ }^{45}$ cobran sentido no sólo los elementos de los juicios filosóficos clásicos sobre la conducta sexual no marital, sino también juicios similares sobre dicha conducta alcanzados por gente decente que no puede articular premisas para explicar esos juicios, a los que llegan más por una introspección sobre qué es y qué no es coherente con las realidades cuya bondad perciben y comprenden lo suficientemente bien como para desearlas y elegirlas. En particular, comienzan a aparecer los elementos de una respuesta a la pregunta: ¿por qué la amistad no marital no puede ser expresada y promovida por actos sexuales? ¿Por qué es el intento de expresar afecto mediante el sexo orgásmico no marital, la búsqueda de una ilusión? ¿Por qué Platón, Sócrates, Xenofonte, Aristóteles, Musonio Rufo y Plutarco, en el corazón de sus reflexiones acerca de la cultura homoerótica que los rodeaba, hacen el juicio deliberado y cuidadoso acerca de la incapacidad de la conducta homosexual (y toda gratificación sexual extramarital) para participar y profundizar el bien común de la amistad?

La respuesta está implícita en el rechazo filosófico y del sentido común al sexo extramarital: la unión de los órganos procreadores de los esposos realmente los une biológicamente (y la realidad biológica es una parte, y no meramente un instrumento de su realidad personal); la procreación es una función y entonces, en lo que respecta a esa función, los esposos son una realidad, y su unión sexual puede actualizar y permitirles experimentar su verdadero bien común - su matrimonio con los dos bienes, la paternidad y la amistad, que (dejando de lado el orden de la gracia) son las partes de su todo como un bien común inteligible, incluso si, independientemente de lo que los esposos quieran, su capacidad para la paternidad biológica puede satisfacerse con el acto de la unión genital- Pero el bien común de amigos que no están ni pueden estar casados (por ejemplo, hombre y hombre, hombre y

45 Juan Pablo II, Veritatis splendor, 1984, 13, 48; véase también id. en 50, 67, 78,79 . 
niño, mujer y mujer) no tiene nada que ver con tener hijos, y sus órganos reproductores no pueden realizar una unidad biológica (y por ende personal). ${ }^{46}$ Entonces, los actos sexuales entre ellos no pueden lograr lo que esperan e imaginan. Como la activación de uno o cada uno de sus órganos sexuales no puede ser una actualización o una experiencia del bien marital - como sí puede serlo el sexo marital (coito entre esposos de manera marital), incluso entre cónyuges que resultan ser estériles-, no puede hacer más que proveer a cada parte de una gratificación individual. A falta de un bien común que pueda ser profundizado y experimentado por y en esta unión corporal, esa conducta lleva a las parejas a usar sus cuerpos como instrumentos para una experiencia de auto-conciencia; su decisión de llevar adelante esa conducta, por tanto, des-une a cada miembro de la pareja, precisamente por tratarse de dos personas que actúan. ${ }^{47}$

La realidad es conocida en la razón, no en la emoción; en la realidad cualesquiera que fueren los sueños y deseos generosos o los pensamientos de entrega con los que algunas parejas del mismo sexo encaran sus actos sexuales, éstos no pueden hacer o expresar más de lo que se expresa cuando dos extraños acometen la

46 Macedo, Steven, "The New Natural Lawyers", The Harv. Crimson, el 28 de octubre de 1993, escribe:

En efecto, los "gays" pueden tener sexo en una forma abierta a la procreación y a una nueva vida. Pueden estar, y muchos lo están, preparados para comprometerse en cualquier clase de relaciones amorosas que podrían resultar en la procreación — si las condiciones fueran diferentes-. Al igual que en los matrimonios estériles, para muchos sería su mayor deseo.

Aquí, la fantasía se despide de la realidad. La relación anal u oral, sea entre esposos u hombres, no es más unión biológica "abierta a la procreación” que la relación de un pastor con una cabra, fantaseando él con engendrar un fauno; cada uno produciría al mutante deseado "de ser las condiciones diferentes". La unión biológica entre los humanos es la inseminatoria del órgano genital del hombre con el órgano genital de la mujer; en la mayoría de los casos, no resulta en procreación, pero es el comportamiento el que une biológicamente porque es el comportamiento el que como tal da la posibilidad de procreación.

47 Para la argumentación completa, véase Grisez, supra nota 35, en 634-39, 648-54, 662-4. 
misma actividad simplemente para brindarse placer recíprocamente, o cuando una prostituta complace a su cliente por dinero, o cuando un hombre se masturba para darse el gusto o fantasear con una relación más humana luego de una ardua jornada de trabajo frente a una línea de montaje. Esta es, creo, la sustancia del juicio de Platón - en esa parte de Gorgias que también resulta decisiva para la crítica moral y político-filosófica del hedonismo - :48 que no existe una diferencia importante, en lo que a valor moral se refiere, entre la masturbación solitaria, un acto de sodomía con una prostituta y la sodomía compartida por placer. Los actos sexuales no pueden ser realmente de auto-entrega, excepto que sean actos por los cuales un hombre y una mujer realizan y experimentan sexualmente la entrega verdadera de uno al otro - en una unión afectiva, biológica y voluntaria, en un compromiso mutuo exclusivo y perpetuo - que al igual que Platón y Aristóteles y la mayor parte de la gente llamamos matrimonio.

En síntesis, los actos sexuales no son unitivos en su significado a menos que sean maritales (poniendo en acto la unidad del matrimonio en todos sus niveles) y (como el bien común del matrimonio tiene dos aspectos) no son maritales a menos que tengan no sólo la generosidad de los actos de amistad, sino también su significado procreador; esto es, que aunque no necesariamente sean realizados con la voluntad de procrear o aunque no sean, en determinadas circunstancias, capaces de procreación, no obstante sean, como conducta humana, actos de tipo reproductivo: actualizaciones, en la medida en que los esposos puedan en las circunstancias concretas, de la función procreadora en la cual son biológica y por ello personalmente uno.

Los antiguos filósofos no discuten demasiado el caso de los matrimonios estériles, o el hecho (bien conocido por ellos) de que por largos periodos de tiempo (por ejemplo, durante el embarazo) los actos sexuales de una pareja casada son naturalmente incapaces de causar generación. Parecen dar por sentado lo que

48 Platón, Gorgias, 494-5, especialmente 494el-5, 495b3. 
la tradición cristiana concluyó tiempo más tarde: que dicha esterilidad no convierte a los actos sexuales conyugales en no maritales (Plutarco indica que el sexo con un esposo estéril es una muestra deseable de estima y afecto marital). ${ }^{49}$ En efecto, cuando marido y mujer unen sus órganos reproductores en un acto sexual que, en la medida en que pueden hacerlo, es un acto apto para generar vida, funcionan como una unidad biológica (y por tanto personal) y, luego, pueden estar actualizando y experimentando el bien común de ser dos en una sola carne y la realidad del matrimonio, aun cuando alguna condición biológica impida la fecundidad de la unión. Su conducta difiere radicalmente de los actos de un marido con su mujer que revistan las características de la masturbación, como por ejemplo la sodomía, la fellatio y el coitus interruptus. ${ }^{50}$ Para la ley, tales actos no consuman el matrimonio porque, en realidad (no obstante la ilusión de intimidad y de entrega al otro de la pareja), no actualizan el bien marital de ser dos partes y una sola carne.

49 Plutarco, Vida de Solón, 20, 3. La filosofía moral post-cristiana de Kant identificó la mala acción de la masturbación y la conducta homosexual (y bestial) como consistente en la instrumentalización del propio cuerpo y ("siendo la persona una unidad absoluta") como el "mal a la humanidad en nuestra persona". Pero Kant, aunque enfatiza la igualdad entre el marido y la mujer (imposible en el concubinato o en una prostitución más casual), no integró esta idea con un entendimiento del matrimonio como un único bien de dos partes que involucra inseparablemente tanto a la amistad como a la procreación. Por ello dudaba ante la pregunta de por qué la relación marital es correcta cuando la mujer está embarazada o en la menopausia. Véase Kant, Immanuel, La metafisica de las costumbres, 277-79, 424-29 (trad. Mary Gregor, Cambridge University Press, 1991, 96-97, 220-22) (1797). El origen profundo de esta duda es su negativa a permitir que los bienes inteligibles tuvieran algún rol estructural en su ética, una negativa que lo coloca en contra de una filosofía moral clásica como la de Aristóteles, y ciertamente contra cualquier teoría adecuada de la ley natural, y, a la vez, está conectada con su separación dualista entre cuerpo, y mente y cuerpo (sic), una separación que choca con su propia idea, recién citada, de que una persona es una unidad real.

50 O deliberadamente anticonceptivo, que omití de la lista en el texto, sólo porque no sería aceptado ahora por la ley civil secular como obstativo de la consumación: una falla de comprensión. Véase comentario supra nota 46. 
¿Significa esto hacer "juicios morales basados en hechos naturales"? ${ }^{51}$ Sí y no. No en el sentido de que no busca inferir conclusiones o tesis normativas de premisas no normativas (consistentes en hechos naturales). Tampoco apela a normas como "deben respetarse los hechos naturales o funciones naturales". Pero sí aplica razones prácticas pertinentes (especialmente que el matrimonio y la integridad interior son bienes humanos básicos) y principios morales (especialmente que uno nunca debe buscar destruir, dañar, impedir o violar bienes humanos básicos, o preferir una instancia ilusoria de un bien humano básico a una instancia real de ese u otro bien humano) a datos referidos al organismo humano personal.

VI. Sociedades como la Atenas clásica y la Inglaterra contemporánea (y, virtualmente, toda otra) trazan una distinción entre el comportamiento meramente (tal vez extremadamente) ofensivo (tal como comer excrementos) y el comportamiento que es repudiado como destructor del carácter y de las relaciones humanas. La cópula de humanos con animales es repudiada porque trata a la actividad sexual y a la satisfacción humanas como algo buscado, divorciado de un bien común inteligible, igualado a las cópulas instintivas de las bestias — y así, trata a la vida del cuerpo humano en una de sus actividades más intensas, como vivida apropiadamente, aun siendo meramente animal-. La cópula genital deliberada de personas del mismo sexo es repudiada por una razón muy similar. No es simplemente por ser estéril y dispo-

51 Macedo, supra nota 40, en 2:

Todo lo que podemos decir es que las condiciones deberían ser más radicalmente diferentes, en el caso de las parejas de "gays" y de lesbianas que en el caso de matrimonios estériles, para que una nueva vida resulte del sexo... pero ¿cuál sería la fuerza moral de esto? La nueva teoría de la ley natural no hace juicios morales basados en hechos naturales.

La frase de Macedo "basados en" se equivoca entre las primeras premisas de los argumentos normativos (que deben ser normativos) y otras premisas (que pueden y por lo general deben estar basados en hechos y, si fuera apropiado, pueden referirse a hechos naturales, tales como el de que la boca de los seres humanos no es un órgano reproductor). 
ner a los participantes a la abdicación de la responsabilidad por el futuro de la humanidad. Ni es simplemente porque no puede verdaderamente realizar la mutua devoción que algunas personas homosexuales esperan manifestar y experimentar por medio de ella y que daña las personalidades de sus participantes por la manipulación que des-integra las diferentes partes de su única realidad personal. Es también repudiada porque trata las capacidades sexuales humanas de manera profundamente hostil a la convicción de aquellos integrantes de la comunidad que desean comprometerse en un verdadero matrimonio, en el entendimiento de que sus goces sexuales no son un mero instrumento, o un accesorio, o meras compensaciones, en vistas al cumplimiento de las responsabilidades del matrimonio, sino más bien que esos goces ayudan a los esposos a actualizar y tener la experiencia de su compromiso inteligente de compartir esas responsabilidades, ese genuino darse mutuamente.

Ahora, como ya he dicho, "la orientación homosexual", en uno de los dos principales sentidos de ese término altamente equívoco, es precisamente el deseo deliberado de promover y realizar actos homosexuales - el estado mental, la voluntad y el carácter cuya propia interpretación llegó a ser expresada con el deplorable pero provechosamente revelador nombre de "gay"-. Esa voluntad y toda la ideología "gay" trata a las capacidades sexuales de una manera profundamente hostil hacia el entendimiento que tienen de sí mismos los miembros de la comunidad que están deseando comprometerse en un verdadero matrimonio.

En este sentido, la orientación homosexual es, de hecho, una permanente negación de la aptitud intrínseca de la relación sexual para actualizar y, en ese sentido, expresar, la exclusividad y el compromiso ilimitado del matrimonio como algo bueno en sí mismo. Todo el que acepte que los actos homosexuales pueden ser un uso humanamente apropiado de las capacidades sexuales, debe, si es coherente, considerar a las capacidades, a los órganos y a los actos sexuales como instrumentos de gratificación personal de los "individuos" que los poseen. Tal aceptación es co- 
múnmente (y en mi opinión correctamente) juzgada como una amenaza activa para la estabilidad de los matrimonios existentes y los futuros; convierte en un sinsentido, por ejemplo, a la posición según la cual el adulterio es per se (y no meramente porque puede conllevar un engaño), y de una manera significativa, contradictorio con el amor conyugal. Una comunidad política que juzga que la estabilidad y la generosidad protectora y educativa de la vida familiar es de fundamental importancia para el presente y el futuro de esa comunidad, puede juzgar correctamente que tiene un fuerte interés en negar que la conducta homosexual - un "estilo de vida gay" - sea una elección y forma de vida válida y humanamente aceptable, y en hacer todo lo que apropiadamente esté dentro de sus amplias funciones como comunidad, siempre sujetas al principio de subsidiariedad, para desalentar tal conducta.

VII. He prometido defender el criterio de que el gobierno de las comunidades políticas es subsidiario y está racionalmente limitado, no sólo por el derecho constitucional y por las normas morales que limitan la deliberación y las elecciones de toda persona decente, sino también por los límites inherentes al objetivo, propósito o fundamento que lo justifican. Ese fundamento es, por supuesto, el bien común de la comunidad política. Y argumentaré que ese bien común no es básico, intrínseco o constitutivo, sino más bien instrumental.

Cada comunidad está constituida por la comunicación y la cooperación entre sus miembros. Decir que una comunidad tiene un bien común es simplemente decir que la comunicación y la cooperación tienen un fin sobre el que sus miembros concuerdan, más o menos, en que debe ser comprendido, valorado y perseguido. Hay tres tipos de bien común, y cada uno de ellos provee el fin constitutivo de un tipo diferente de comunidad abierta, y realiza, a su vez, un bien humano básico: (1) la ayuda afectiva mutua y el placer compartido de la amistad y la communio de "verdaderos amigos"; (2) el compartir el marido y la mujer en la vida matrimonial, unidos como personas corporales complemen- 
tarias, cuyas actividades las hacen aptas para la paternidad - la communio de los esposos y, si el matrimonio es fructífero, la de sus hijos-; (3) la communio de los creyentes, que cooperan en la devoción y en los servicios del culto requeridos por lo que ellos creen que son verdades accesibles sobre la fuente última de todo significado, valor y demás realidades, y sobre las maneras en las que los seres humanos pueden estar en armonía con esa fuente última. Las demás comunidades humanas, o bien están dedicadas a alcanzar una meta específica o un conjunto de metas (como una universidad, un hospital), y por lo tanto no están al servicio ilimitado de sus miembros, o bien tienen un bien común que no es básico sino instrumental. Cabe hacer notar que la asociación y la cooperación, aun cuando estén orientadas hacia fines específicos e instrumentales, más que básica e intrínsecamente buenas (como por ejemplo, en una empresa de negocios), tienen un carácter meramente instrumental, ya que actualizan el bien básico de la amistad en alguna de sus formas centrales o no centrales.

La comunidad política - bien entendida como una de las formas de colaboración necesarias, en beneficio de los bienes básicos, identificados por los primeros principios de la ley natural - es una unidad que coopera en el servicio de un bien común que es instrumental, no básico en sí mismo. Es verdad que es un bien "grande y divino" 52 en su ambicioso contenido: "asegurar todo el conjunto de condiciones materiales y de otro tipo, incluyendo formas de colaboración, que tienden a favorecer, facilitar y fomentar el desarrollo personal de cada individuo [en esa comunidad]"53 (que incluirá, en cada caso, constitutiva-

52 Aristóteles, Ética nicomaquea, 1, 1; 1094 b 9.

53 Finnis, John, Natural Law and Natural Rights, 1980, 147. Como indico, esta definición de bien común de la sociedad política es similar a la que llegaron los comentaristas franceses de Aquino al principio de mediados del siglo veinte. Ibidem, en 160. Una definición similar fue adoptada por el Concilio Vaticano II: "esa suma de condiciones que consienten a los individuos y a las colectividades alcanzar su propia perfección más plena y rápidamente”, Gaudium et spes, 1965, 26; véase también Dignitatis Humanae, 1965, 6. 
mente, el florecimiento de la familia, de la amistad y de otras comunidades a las que la persona pertenezca). También es cierto que su rango propio incluye la reglamentación de amistades, matrimonios, familias y asociaciones religiosas, como también la de muchas organizaciones y asociaciones que están dedicadas a fines específicos o que, como el Estado mismo, satisfacen un bien común meramente instrumental (por ejemplo, económico). Pero tal reglamentación de estas asociaciones no debería nunca (en el caso de las asociaciones con un bien común no instrumental), o debería tan sólo excepcionalmente (en el caso de asociaciones instrumentales), intentar asumir la autoridad de la formación, dirección o administración de esas iniciativas personales y asociaciones interpersonales. Más bien, su propósito consiste en llevar a cabo la función subsidiaria ${ }^{54}$ (esto es, auxiliar, del latín subsidium, ayuda) de asistir a individuos y grupos en la coordinación de sus actividades teniendo en cuenta los objetivos y compromisos que hubieran elegido, y para hacerlo de manera consistente con los otros aspectos del bien común de esa comunidad, singularmente compleja, abarcadora y exigente en su razón de ser, sus requerimientos de cooperación y en su monopolización de la fuerza: la comunidad política. ${ }^{55}$

54 Véase, Finnis, supra en 146-47, 159.

55 Ciertamente, el bien común de la comunidad política tiene elementos importantes que son poco compartidos con otras comunidades intermedias: por ejemplo, la restauración de la justicia por medio del castigo a aquellos que hubieran ofendido a la ley justa; la represión y el constreñimiento coercitivo de aquellos cuya conducta (en la que se incluye la omisión negligente) amenaza injustamente los intereses de terceros, particularmente esos intereses identificados como derechos morales ("humanos") o legales, y las medidas obligatorias correspondientes para asegurar la restitución, compensación o reparación de la violación de derechos; y la determinación y defensa de un sistema de derechos de posesión o propiedad que respete los diversos intereses, inmediatos y conferidos o remotos y eventuales que todos tienen en cada propiedad. Pero el hecho de que esos y otros varios elementos del bien común político sean propios de la comunidad política y responsabilidad de los dirigentes - el gobierno-, de ninguna manera los convierte en bienes humanos básicos, o significa que el bien común político no sea más que instrumental en sí mismo. 
El carácter fundamentalmente instrumental del bien común político está indicado en las dos partes en que el Concilio Vaticano II se refiere a la libertad religiosa, una enseñanza considerada por el Concilio como materia de ley natural (esto es, de "la razón misma"). ${ }^{56}$ La primera parte de la enseñanza es que todos tienen derecho a no ser coercionados en materias de creencia y práctica religiosa. Porque el conocer la verdad sobre temas fundamentales, compendiosamente llamados "religiosos" por el Concilio, y el adherirse a ellos y poner en práctica la verdad que uno ha llegado a conocer, es un bien tan significativo y una responsabilidad tan básica, y la consecución de "este bien del espíritu humano" ${ }^{57}$ es tan inherente y tan insustituiblemente un asunto de aquiescencia personal, de decisión consciente, que si un gobierno interviniese coercitivamente en la búsqueda personal de creencias religiosas verdaderas o en la expresión popular de las creencias que se suponen verdaderas, dañaría a esa gente y violaría su dignidad, aun cuando su intervención estuviera basada en la correcta premisa de que su búsqueda ha sido conducida negligentemente y/o los ha llevado hacia creencias falsas. Los actos religiosos, de acuerdo con el Concilio, "trascienden" la esfera propia de los gobiernos; el gobierno debe ocuparse del bien común temporal y esto incluye (la función subsidiaria de) reconocer y promocionar la vida religiosa de sus ciudadanos, pero los gobiernos no tienen la responsabilidad ni el derecho a dirigir los actos religiosos y "exceden sus propios límites" si pretenden hacerlo. ${ }^{58}$

La segunda parte de las enseñanzas del Concilio concierne a las restricciones apropiadas a la libertad religiosa, principalmente aquellas restricciones que son

56 Dignitatis humanae, 2. En la parte siguiente, la declaración trata el asunto como revelación divina. Ibidem, en 9-14.

57 Es una de las animi humani bona, mencionadas en ibidem, 1.

58 "Potestas igitur civilis, cuius finis proprius est bonum commune temporale curare, religiosam quidem civium vitam agnoscere eique favere debet, sed limites suos excedere dicenda est, si actus religioso dirigere vel impedire praesumat", ibidem, en 3. 
requeridas para [i] la efectiva protección de los derechos de todos los ciudadanos y su coexistencia pacífica, [ii] un cuidado suficiente de la auténtica paz pública y de una vida en común ordenada en verdadera justicia, y [iii] un sostenimiento adecuado de la moralidad pública. Todos estos factores constituyen la parte fundamental del bien común y están contenidas en la noción de orden público. ${ }^{59}$

Aquí también el bien común político está presentado como instrumental, al servicio de la protección de los derechos humanos y legales, de la paz pública y de la moralidad pública - en otras palabras, la preservación de un entorno social conducente a la virtud-. El gobierno no está precisamente presentado aquí como dedicado al dominio de la virtud y a la represión del vicio como tales, aun cuando la virtud (y el vicio) son de importancia suprema y constitutiva para el bienestar (o malestar) de los individuos y el valor (o disvalor) de sus asociaciones.

¿Es correcta la enseñanza del Concilio sobre la ley natural? ¿O deberíamos adherir a la más sencilla teoría de Aquino expuesta en su tratado De regimine Principum, a saber, que el gobierno debería mandar todo lo que lleve a la gente hacia su fin último (celestial), prohibir todo lo que los aparta del mismo, y coercitivamente impedir a la gente de hacer el mal e inducirla a la conducta moralmente decente? ${ }^{60}$ ¿Acaso tal vez la respuesta corta más persuasiva de esta enseñanza es todavía el famoso ataque de Aristóteles a las teorías que, como la del sofista Licofrón, tratan al Estado como a un mero arreglo para la seguridad mutua?61

\section{Ibidem, en 7.}

60 De regime principum, c. 14 (...ab iniquitate coerceat et ad opera virtuosa inducat). Esta tesis está matizada, aunque no abandonada, en otras obras de Aquino. Así, en la Summa Theologiae, II-II q. 104 a.5c, enseña que el gobierno humano no tiene autoridad alguna sobre las mentes de las personas y sobre los movimientos internos de su voluntad. Ibidem, I-II q.96 a.2, enseña que la búsqueda gubernamental de la virtud debería ser gradual y no debería exigir demasiado del ciudadano medio (el que no es virtuoso).

61 Aristóteles establece: "La polis fue formada no solamente para beneficio de la vida, sino más bien para la buena vida... y... su propósito no es [meramen- 
Pero en dos aspectos cruciales, al menos, Aristóteles (y, con él, la tradición) ha tomado la cosa demasiado a la ligera.

Primero: si el objeto, el fin o bien común de la comunidad política fuera, ciertamente, lograr una vida autosuficiente, y si la autosuficiencia (autarcheia) fuera ciertamente lo que Aristóteles define como tal - una vida en la que no falta nada, de completa realización - 62 entonces tendríamos que decir que la comunidad política tiene un objetivo que no puede tener esperanzas de alcanzar un bien común que está mucho más allá de su alcance. Porque la reflexión filosófica subsecuente ha confirmado lo que uno podía ya sospechar observando la oscilación manifiesta de Aristóteles entre los diferentes conceptos de eudaimonia (y por lo tanto, autarcheia): la satisfacción humana completa es nada menos que la satisfacción (en principio) de todas las personas humanas, en todas las comunidades, y no puede ser alcanzada en ninguna comunidad, salvo el reino celestial; una comunidad vislumbrada no por la pura razón (teoría de ley natural), sino sólo gracias a la revelación divina; y que sólo puede alcanzarse por medio de

te] el de una alianza militar para la defensa... y no existe [meramente] para el beneficio de las relaciones comerciales y de negocios... cualquier polis verdadera y que no es tal meramente de nombre, debe tener a la virtud/excelencia como un objeto de su cuidado (peri aretes epimeles einai: ser solícita de la virtud]. De otra manera una polis cae en una mera alianza, distinta sólo por una cuestión espacial de otras alianzas en las que los miembros viven a mayor distancia unos de otros. De otra manera también, la ley se convierte en un mero contrato social [syntheke, contrato] - o (en las palabras del sofista Licofrón) en un «garante de la justicia, como entre un hombre y otro» - en vez de ser, como debería, de tal manera que hiciera [poiein] a los ciudadanos, buenos y justos... La polis no es solamente compartir una localidad común con el propósito de prevenir las lesiones recíprocas o intercambiar bienes. Estas son precondiciones para la existencia de una polis... pero una polis es una communio (koinomia) de clanes (y vecindarios) para el buen vivir, con el objetivo de lograr una vida completa y auto-suficiente [autarkous] ...por lo tanto, debe ser en beneficio de acciones verdaderamente buenas (kalon) y no de un mero vivir juntos”. Aristóteles, Política, III.5: 1280a32, a35, 1280b7-13, b30-31, b34, 1281 al-4.

62 Aristóteles, Ética nicomaquea, I, 7: 1097b8. Esto, dicho sea de paso, difiere con amplitud de lo que Macedo, Stephen, Liberal virtues, 1990, 21517, quiere decir con "una persona autárquica". 
un don divino que trasciende las capacidades de la naturaleza. Por supuesto, la plenitud humana integral puede y debe ser el concepto central de una teoría moral basada en la ley natural, y, por ende, de una teoría política basada en la ley natural, y debería ser concebida como una especie de comunidad ideal (que responderá a la realidad del reino que la principal norma moral de la fe cristiana nos incita a buscar). ${ }^{63}$ Pero esa comunidad ideal no es la propuesta prematuramente en las primeras teorías de la ley natural, como la de Aristóteles; esa comunidad ideal no es la comunidad política.

Segundo: cuando Aristóteles habla de "hacer" buena a la gente, constantemente ${ }^{64}$ usa la palabra poiesis, que tantas veces ha contrastado con praxis y reservado para las técnicas (artes) de manipulación de la materia. ${ }^{65}$ Pero ayudar a los ciudadanos a elegir y actuar de acuerdo con la realización humana integral debe involucrar algo que va más allá de cualquier arte o técnica. Porque sólo los individuos, actuando personalmente, pueden hacerse buenos o malos por elección. No es que sus vidas deban o puedan ser individualistas; su deliberación y su elección estarán moldeadas y ayudadas o impedidas por el lenguaje de su cultura,

63 Porque nada que no sea la plenitud humana integral, la plenitud de todas las personas en todos los bienes humanos básicos, responde al conocimiento total por la razón y al interés total de la voluntad, por aquel bien humano del que se puede participar por medio de la acción. Y por eso el primer principio de una sana moral debe ser: cuando se trata de actuar voluntariamente en pos de los bienes humanos y evitar lo que se opone a ellos, se deben elegir y desear solamente aquellas posibilidades cuyo deseo es compatible con la plenitud humana integral. Decir que la inmoralidad está constituida por la reducción, por la traba de la razón, por las pasiones, es equivalente a decir que el poder de los sentimientos sobre la razón constituye una inmoralidad al desviar al hombre hacia objetivos que no están de acuerdo con la plenitud humana integral. Esta comunidad ideal es, por lo tanto, el ideal más fundamental para la orientación de la buena voluntad.

64 Aparte del pasaje recién citado, véase Aristóteles, Ética nicomaquea, I, 10 : 1099b 32; II 1: 1103-4; X, 9: 1180b 24.

65 Por ejemplo, Aristóteles, Ética nicomaquea, VI, 5; 1140a 2; Aristóteles, P0lítica, 1, 2: 1254a 5 . 
por su familia, sus amigos, sus asociados y sus enemigos, por las costumbres de su comunidad, por las leyes de su Estado y por la impronta de influencias humanas de muchas clases provenientes de lugares que trascienden las fronteras de su comunidad natal. Sus elecciones los involucrarán en relaciones con otras personas de todas esas comunidades, relaciones justas o injustas, generosas o mezquinas, vengativas o caritativas. Y como miembros de todas esas comunidades, tienen la responsabilidad de alentar a sus compañeros hacia lo moralmente bueno y de desalentarlos respecto de la conducta moralmente mala.

Sin lugar a dudas, la comunidad política es una cooperación que sobrelleva las tareas únicas de brindar protección coercitiva a todos los individuos y asociaciones legales dentro de su dominio, y de asegurar un entorno económico y cultural en el que todas estas personas y grupos puedan perseguir su propio bien. Sin lugar a dudas, este bien común de la comunidad política la convierte en mucho más que un mero arreglo para "prevenir las lesiones recíprocas e intercambiar bienes". Pero una cosa es sostener, como requiere la razón, que la ratio de la comunidad política requiere que la estructura administrativa pública, el Estado, deba identificar, fomentar, facilitar y sostener, deliberada y públicamente, aquello que es verdaderamente valioso (incluyendo la virtud moral); que deba identificar, desalentar y obstaculizar deliberada y públicamente aquello que es dañoso y malo, y que deba, por medio de sus prohibiciones criminales y sanciones (al igual que por sus otras leyes y políticas), asistir a personas con responsabilidades de padres, para educar a los niños y a la gente joven en la virtud y para desalentar sus vicios. Algo muy distinto es, en cambio, sostener que esa ratio requiere o autoriza al Estado a dirigir a la gente hacia la virtud y alejarla del vicio incluso por medio de la penalización de actos viciosos realizados por adultos en secreto y verdaderamente consensuales. ${ }^{66}$

66 Entonces, una tercera forma en que Aristóteles se toma las cosas demasiado a la ligera es el modo en que pasa de apoyar la responsabilidad del gobierno de asistir o sustituir a la disciplina paterna de la juventud, a sostener que esta 
Entonces, había una sana e importante distinción de principio que la Suprema Corte de Estados Unidos pasó por alto al cambiar su doctrina de Griswold v. Connecticut67 (uso privado de anticonceptivos entre esposos) por la de Eisenstadt v. Baird (distribución pública de anticonceptivos a gente soltera). ${ }^{68}$ La verdad y la relevancia de esa distinción, y su gran importancia para el bien común, volvería a ser pasada por alto si las leyes que criminalizan los actos privados de sodomía entre adultos llegaran a ser invalidadas por la Corte sobre la base de cualquier criterio que conllevara también el requerimiento constitucional de que las leyes toleren la publicidad o el marketing de servicios homosexuales, el mantenimiento de lugares de recreación para la actividad homosexual o la promoción de "estilos de vida" homosexuales por medio de la educación y los medios públicos de comunicación, o el reconocimiento de "matrimonios" homosexuales, o permitiera la adopción de niños por personas homosexualmente activas, y así sucesivamente.

responsabilidad continúa, y en forma igualmente coercitiva, "cubriendo toda una vida, ya que la mayoría de la gente obedece a la necesidad más que a los argumentos, y al castigo antes que al sentido de lo que verdaderamente vale la pena". Aristóteles, Ética nicomaquea, X, 9:1180a 1-3.

67381 U.S. 479 (1965).

68405 U.S. 438 (1972). La ley atacada en Griswold fue la ley que prohíbe el uso de anticonceptivos incluso entre personas casadas. La convicción de Griswold, como un accesorio a dicho uso, cayó con la caída de la ley sustancial que sancionaba a los autores principales de tales usos. Muy diferente, en principio, hubiera sido una ley que prohibiera directamente las actividades de Griswold como promotor público de la información sobre anticonceptivos y su suministro. Si el derecho constitucional norteamericano no logra reconocer tales distinciones, ello muestra, sugiero, su falta de recto principio. 


\section{LA FILOSOFÍA DEL DEREGHO: RAÍCES Y TEMAS REGIENTES*}

El derecho es un medio para introducir y mantener el imperio (el gobierno) de la razón en una comunidad de muchas familias y vecindarios, en lugar del predominio de la violencia privada o el fraude, o de la fuerza de los grupos dominantes que dirigen los asuntos de la comunidad para beneficio de algunos y no de todos sus miembros. Esta es, al menos, la concepción del derecho que ha obtenido aceptación creciente en la filosofía británica y estadounidense contemporánea. Durante la centuria que va desde 1850 hasta 1950 aproximadamente, la opinión prevaleciente entendió al derecho como una manifestación de poder, dominación y mandato, por el cual personas soberanas u organizaciones de personas soberanas expresaban su voluntad acerca de cómo debían comportarse los miembros de las comunidades políticas, y reforzaban tales imperativos mediante la amenaza y la ejecución de sanciones. La opinión ahora predominante no ignora de ninguna manera la necesidad de sanciones impuestas coercitivamente para la recalcitrancia, pero enfatiza la oportunidad y la responsabilidad que tienen quienes establecen las reglas de gobernar en favor del beneficio común, y no del privado o partidario, y de hacerlo así por medios que tiendan a asegurar que todas las decisiones relevantes sean tomadas con arreglo a la verdad acerca de los hechos y con transparencia y justicia (fairness) en los procedimientos legislativo, ejecutivo y judicial.

* "Legal Philosophy: Roots and Recent Themes", en Finnis, John, Collected Essays, vol. IV: Philosophy of Law, Oxford, Oxford University Press, 2011, pp. 157/173. John Finnis es Emmeritus Professor en la Universidad de Oxford y Biolchini Professor of Family Law en la Universidad de Notre Dame. Versión española de Eduardo R. Sodero. 
La visión más moderna recupera de ese modo la tradición establecida en las reflexiones clásicas acerca del derecho que se encuentran en las obras de Platón, Aristóteles, Cicerón y, en el siglo XIII, de Tomás de Aquino. Dentro de la filosofía jurídica contemporánea, la oposición a este entendimiento del derecho como medio de asegurar el orden social justo proviene no tanto de los defensores de una resucitada teoría de la "voluntad" que destaca las órdenes y la fuerza, cuanto de quienes proponen visiones escépticas de que en verdad haya alguna "razón" a descubrir y aplicar, o alguna consecuencia justa determinable a ser alcanzada por el razonamiento judicial o la deliberación legislativa. El presente ensayo es escrito por un filósofo y abogado que considera que tales objeciones escépticas son generalmente infundadas, y que el reciente "retorno" de la filosofía del derecho occidental a sus raíces clásicas — reconceptualizadas y críticamente asumidas- está bien justificado.

La opinión predominante desde c. 1850 hasta c. 1950 por lo común es llamada "positivismo" o "positivismo jurídico". La visión clásica, revitalizada en las décadas recientes, es comúnmente denominada "teoría del derecho natural" (natural law theory). Se trata de rótulos confusos, porque cada una es precisamente una teoría del derecho positivo, es decir, del derecho hecho por, o adoptado - impuesto - para una específica comunidad por personas identificables que pretenden tener la autoridad de hacer o aplicar reglas cuya validez se deriva inmediatamente (si no finalmente) del hecho de que esas personas las han hecho autoritativamente o, al menos, las han determinado. Además, la "naturaleza" a la que se hace referencia en el título "derecho natural" no es la naturaleza estudiada por las "ciencias naturales". Antes bien, ella es entendida por los defensores de la teoría del derecho natural como el bienestar humano - florecimiento humano, naturaleza humana en buena forma- en todos sus aspectos básicos y en todas las personas y comunidades humanas, en cuanto implícita o explícitamente favorecido y respetado por un conjunto de principios que orientan las elecciones humanas hacia acciones correc- 
tas y alejadas de lo injusto, incluyendo las acciones de quienes hacen (imponen) las leyes (como legisladores o como jueces) o las hacen cumplir por la fuerza (ejecutiva o judicialmente).

Así, se está efectivamente de acuerdo en que el derecho - el derecho positivo - debe ser distinguido de las leyes de la naturaleza (que discuten la física, la química, la biología, la cosmología, etcétera), de las leyes del pensamiento (discutidas por los lógicos) y de la ley moral (que discuten los teóricos de la ética y los moralistas). Por cierto que, a lo largo de su historia, la filosofía jurídica ha procurado diferenciar el derecho positivo (en adelante simplemente "derecho" o "el derecho") de todos esos otros estándares. Pero tal diferenciación puede tener más de un propósito teórico. Ella puede dirigirse a clarificar la terminología y los límites conceptuales. O igualmente puede intentar indagar si las analogías u otras relaciones entre el derecho (positivo) y tales estándares o normas de otros órdenes o dominios ontológicos y epistemológicos son analogías y relaciones que ayudan a explicar lo que es más difícil de entender respecto del derecho. Y lo que la teoría del derecho occidental ha considerado característicamente como lo más dificil de entender del derecho son quizá estas tres características: (a) que el derecho puede "exigir" (necessitate) (hacer obligatorias, en realidad, moralmente obligatorias) acciones que, hasta su sanción, no eran exigibles de ese modo; (b) que las_reglas jurídicas y otras "instituciones" de alguna manera "existen" en virtud de, pero también mucho después de, su imposición por la legislación u otra "sanción jurídica", o por precedente judicial o por costumbre; (c) que muchas de las reglas del derecho tienen una forma normativa y una función social distintas de sus reglas que imponen obligaciones, y (d) que el derecho apela a la coerción penal y correctiva para prohibir la fuerza (como así también la deshonestidad y la negligencia) en las relaciones interpersonales.

El vínculo entre la teoría o filosofía jurídica contemporánea y la clásica puede ser rastreado hasta el mundo griego en los siglos VI y V a. C.; los fragmentos sobrevivientes de los presocráticos 
insinúan un fuerte debate que hoy en día, sin embargo, no ha podido ser reconstruido con certeza. La conversación accesible de la filosofía jurídica occidental en realidad comienza con dos breves diálogos que reflejan los debates en los círculos socráticos: una ingeniosa conversación puesta por Jenofonte en los labios de los políticos atenienses Alcibíades y Pericles (Memorabilia, I, 2), y un diálogo "socrático" inciertamente atribuido a Platón (el Minos). Cada uno retrata las dificultades que aguardan a los filósofos que definen al derecho como cualesquiera que sea lo que sancionen los gobernantes (rulers), y se olvidan de, o rechazan, referirse a problemas de derechos (morales), tales como los de si los súbditos de la ley la han aceptado de alguna manera (Jenofonte) o si lo que ella dispone es bueno, verdadero y conforme con "lo que existe en la realidad" (Minos, 313b - 317d). Ambos diálogos sugieren que si bien toda persona entiende el sentido en el cual la (in)justicia de una ley es irrelevante para su realidad empírica de estar asegurada por la sanción, existe - no obstante ello- buena razón (good reason) para decir que, en una comprensión más adecuada del derecho, las leyes injustas son "más un asunto de fuerza que de derecho" y son "derecho no sin calificación" (Minos, $314 \mathrm{e})$.

Así, surgen en los inicios del siglo IV a. C. dos posiciones, cada una de las cuales todavía es defendida en la filosofía angloparlante contemporánea. El positivismo jurídico moderno afirma que, para ser descrito con realismo y claridad, el derecho debe ser considerado sin referencia a ninguno de los predicados morales que el mismo atrae en el discurso (por ejemplo, en la evaluación moral y política), ajeno a la filosofía jurídica. La teoría del derecho natural afirma que tal descripción olvida lo esencial del derecho (the point of law); los sistemas jurídicos obtienen su sentido y su forma (que una buena descripción del derecho ha de identificar) de su esencia, y una evaluación racional de leyes o sistemas jurídicos (o comunidades políticas) particulares utilizará tal esencia (quizá compleja) como criterio para medir su conformidad con, o su desviación de, la verdadera idea de derecho (the 
very idea of law). Platón expresó esta segunda posición: "las leyes que no han sido sancionadas para el interés común de la comunidad toda, no son verdaderamente leyes" (Las Leyes, 715b, también 712e-713a; El político, 293d-3). Cicerón resumió así la visión que era, y hasta el siglo XIX siguió siendo, la principal corriente filosófica: "a la definición exacta del término «derecho» resulta inherente la idea y el principio de elegir lo que es justo y verdadero" (De Legibus, II, 11).

Acerca de esta cuestión de la definición, Platón advertía que el discurso ordinario acerca del "derecho" es una cosa y la definición explicativa del mismo es otra, y que ambas coexisten:

Sócrates: "Cuando quienes sancionan las leyes yerran el bien, entonces también ignoran el derecho y lo legal. ¿O tú qué opinas?"

Hippias: "Hablando con propiedad, Sócrates, ciertamente que eso es así; pero las personas habitualmente no lo dicen de ese modo" (Hippias Major, 284d).

Aristóteles elaboró la versión apropiada de definición en teoría social, inclusive jurídica (véase, por ejemplo, Política, III $1275 a-b)$. En esta versión, la pura descripción o reportaje ("esto y aquello pretenden ser, y por lo común son, llamados amistades, comunidades políticas, constituciones... leyes") puede coexistir con definiciones explicativas en el marco de una teoría que trata la justificación (y, donde es apropiado, la deslegitimación crítica) como el modo primario de explicación. De este modo, el tipo humanamente bueno de, digamos, amistad, comunidad, constitución... o derecho es el paradigma, el caso central escogido por la definición explicativa y por un término correspondiente ("amistad"..., "derecho") en su sentido focal; especies de este tipo bueno son, en este sentido, la amistad, el derecho, etcétera, verdaderos, propiamente o sin calificación (en griego, haplós; en latín, simpliciter). Pero los ejemplos de tipos humanamente deficientes quedan comprendidos en la exposición filosófica de la disciplina, más precisamente como análogos al caso central. La filosofía de los asuntos humanos, tal como es relevante para el derecho, se 
refleja en leyes y sistemas jurídicos decentes, con debida atención sobre lo que hace malas a las leyes y cómo importan las malas leyes (NLNR, caps. X y XII).

Hasta Jeremy Bentham (preanunciado en el siglo XIV por Guillermo de Ockham y Marsilio de Padua, y en el siglo XVII por Francis Bacon, Thomas Hobbes y Baruch de Spinoza) existe poca o ninguna filosofía específicamente jurídica que pueda ser llamada positivista. Por cierto que desde Platón hasta Bentham, la filosofía jurídica fue sustancialmente una filosofía del derecho positivo, una materia considerada como distinta de los demás temas de la filosofía moral y política, pero inteligible adecuadamente sólo sobre la base de los principios morales y de los fines políticos identificados, explicados y defendidos en la filosofía moral y política. La auto-interpretación de la filosofía jurídica precisamente como una filosofía del derecho positivo puede ser rastreada hasta la Summa Theologiae de Tomás de Aquino (c. 1270). $\mathrm{Su}$ análisis del concepto y de los tipos del derecho todavía es leída por muchos filósofos del derecho angloparlantes contemporáneos, y para algunos ha sido altamente influyente.

La expresión "derecho positivo" apareció en Francia hacia 1135, y pronto devino popular entre los juristas teoréticamente formados. Pero la nueva terminología no modificó inmediatamente las antiguas ideas sobre el tema concreto de la reflexión filosófica sobre el/los derecho/s. Aristóteles (NE, 5, 1134b) había dividido lo justo político/la justicia política en natural y legal; la segunda también la describió como convencional y humana. Los juristas del siglo XII tardío y del siglo XIII dividieron el ius (derecho/justo) en natural (la ley moral) y positivo, subdividiendo éste en las categorías del derecho romano del ius gentium (las leyes comunes a todos los pueblos) y del derecho civil (propio de una comunidad determinada). Finalmente, Tomás de Aquino (ST, I-II, q. 95 a. 2) trató la distinción entre derecho natural y civil como una distinción en el seno del derecho positivo (es decir, dentro del derecho humanamente establecido). Algunas partes del derecho positivo son conclusiones de los principios y normas de 
la ley moral natural; para ellas reservó el nombre ius gentium. Las otras partes son puramente positivas, a pesar de estar vinculadas con principios morales a través de una relación inteligible e indeducible que llamó determinatio (concreción).

De ese modo, la ley humana positiva en sus dos partes es finalmente diferenciada como un objeto necesario de la reflexión filosófica. El "teórico del derecho natural" Tomás de Aquino será seguido por el "positivista" de mediados del siglo XIX John Austin en la afirmación de que es por analogía con este analogado primario que entendemos como derecho (a) la ley eterna de la providencia creadora de Dios (comprensiva de todas las leyes que investigan las ciencias naturales), (b) la ley natural, o principios racionales de la buena y correcta deliberación y acción humana, y (c) la "ley divina", es decir, las normas del derecho positivo especialmente promulgadas por revelación divina (por ejemplo, como mandamientos), que incluyen, como la ley humana positiva (eclesiástica o secular), elementos tanto de la ley natural (moral) como de la ley puramente positiva.

Tomás de Aquino describe la ley humana positiva como hecha por la voluntad (es decir, por la decisión de adoptar un esquema en desmedro de otro u otros). Pero cuando habla precisamente, aduce que la ley es un asunto de razón antes que de voluntad; la obligación tiene que ver con los medios requeridos para servir y respetar los fines y principios de la razón práctica; el imperium, por el cual uno, al ejecutar las elecciones propias, se dirige a sí mismo (o, análogamente, como gobernante dirige la propia comunidad) corresponde a la razón antes que a la voluntad. Todo esto pronto encontró oposición, y por los próximos 500 años la filosofía del derecho estuvo dominada por los esfuerzos en explicar la fuente y obligatoriedad del derecho por referencia a la voluntad, ya sea de los superiores o de las partes que acuerdan un contrato social.

El A Fragment of Government de Bentham (1776) inauguró la moderna filosofía del derecho angloparlante al proponer una distinción radical entre los "espacios" (provinces) de los expositores, 
quienes poniendo su atención en los hechos explican lo que es el derecho, y de los "censores", que por medio de atender a las razones consideran lo que el derecho debe ser. La jurisprudencia expositiva de Bentham incluía un tratado, of Laws in General, inédito hasta 1945, pero muy similar a la exposición menos ingeniosa de su pupilo Austin en The Province of Furisprudence Determined (1832): todas las leyes propia y estrictamente así llamadas son órdenes (commands), expresiones de deseo (acompañadas por la amenaza de sanción) del soberano de una comunidad política independiente; aunque sean influyentes en los tribunales, las reglas que no hayan sido creadas o adoptadas por orden soberana no son propiamente leyes; tener una obligación jurídica significa ser el destinatario de una orden y estar expuesto a la sanción que la acompaña; todos los derechos jurídicos, incluyendo los poderes, han de ser explicados en términos de órdenes y de permisiones, o negaciones de obligación, más o menos complejas.

La filosofía del derecho angloparlante permaneció principalmente bajo la influencia de Bentham y Austin por más de cien años (si bien la jurisprudencia histórico-comparativa oscila ampliamente). Incluso cuando los "realistas jurídicos" (legal realists) americanos y otros rechazaron, en el segundo cuarto del siglo $\mathrm{XX}$, que la sustancia del derecho sean las reglas o cualquier otro estándar establecido (posited) por órdenes o por cualesquiera otros actos del pasado, ellos retuvieron y reforzaron la concepción del derecho como un instrumento, en sí mismo moralmente neutro, de "control social" para los propósitos de quienes están en el poder (más exactamente, los tribunales y demás oficiales).

Hans Kelsen (1881-1973), cuyas ideas devinieron influyentes en Gran Bretaña y en América a partir de la década del treinta, y que vivió en los Estados Unidos desde 1940, intentó la unión de temas kantianos con neo-hobbesianos y neo-humeanos. Esta tentativa derivó en una concepción del derecho y del sistema jurídico radicalmente centrada en la orden (command-centre-account of law and legal system). La filosofía jurídica (teoría pura de la ciencia jurídica) debía estar libre de todo valor y de toda referencia al 
hecho tal que pudiera sugerir que la normatividad del derecho deriva de, o es reducible a, su eficacia u otra realidad empírica (Kelsen, General Theory of Law and State y The Pure Theory of Law). Kelsen buscaba, en efecto, una "tercera teoría", compartiendo con la teoría del derecho natural el intento de reproducir y explicar de manera no-reduccionista la normatividad del derecho, y con el positivismo jurídico, el rechazo a toda norma o valor no puesto y hecho efectivo por contingentes actos y hechos humanos. El fracaso de la búsqueda se pone de manifiesto en los muchos cambios de Kelsen entre visiones contradictorias acerca de la fuente y la coherencia de las normas jurídicas, el contenido de normatividad y el significado de las proposiciones de la ciencia jurídica, y en su final confianza abierta sobre "actos de voluntad ficticios" (Kelsen, The Pure Theory of Law, 2a. ed., y su póstuma General Theory of Norms).

Que las explicaciones del derecho y la obligación jurídica deben apuntar a ordenar o aceptar actos de voluntad fue rechazado en la más influyente obra de filosofía jurídica escrita en idioma inglés, The Concept of Law de H. L. A. Hart. Allí, y en su posterior Essays on Bentham, las reglas jurídicas son descritas y explicadas como "razones para acciones, independientes del contenido y perentorias"; sus fuentes pueden ser órdenes, pero igualmente puede ser cualquier hecho que tenga significación normativa atribuida por "una regla (o conjunto de reglas) de reconocimiento" aceptada por jueces y oficiales (por cualquier razón que no sea el temor a la sanción inmediata). No todas las leyes imponen obligaciones; antes bien, muchas confieren poder (autoridad), y una exposición (como la de Austin o la de Kelsen) que reduzca tales reglas que confieren poder, o reglas facultativas, a ser condiciones o prótasis de obligaciones oculta la variedad de formas y funciones normativas del derecho al pasar por alto la variedad de sus funciones sociales. Una filosofía jurídica descriptiva puede y debería (afirma Hart) estar libre de presuposiciones morales; tratando de criticar a Tomás de Aquino, él sostenía que el derecho no está "necesaria o conceptualmente" conectado con la morali- 
dad. Pero la filosofía jurídica debería aducir, entender y "reproducir" el punto de vista o la "actitud interna" de aquellos participantes de un sistema jurídico para quienes el derecho es una razón genuina para la acción y algo con valor (no necesariamente moral). De ese modo, la filosofía jurídica no puede sostener con corrección que el derecho puede tener cualquier contenido.

La multifacética resistencia de Hart a las exposiciones reduccionistas de las realidades jurídicas, y su estrategia de entender al derecho como un tipo de razón creada, conservada y reconocida por específicas razones (distinctive reasons), han impulsado muchas líneas de investigación acerca del carácter (point) y la estructura funcional no sólo del derecho y del sistema jurídico como un tipo general de realidad social, sino también del razonamiento jurídico o la deliberación judicial (por ejemplo, MacGormick, Legal Reasoning and Legal Theory; Schauer, Playing by the Rules), del Estado de derecho como un ideal distintivo del orden político-jurídico (por ejemplo, Raz, The Authority of Law: Essays on Law and Morality) y del determinante aspecto moral y justificación(es) de instituciones jurídicas particulares, tales como el contrato, el daño, el delito, la propiedad y el castigo (por ejemplo, Weinrib, The Idea of Private Law). La atención en el método neo-aristotélico de Hart de explicación por medio de casos centrales y secundarios ha sugerido que, a pesar de su insistencia en la oposición entre el positivismo jurídico que él defendía y cualquier teoría del derecho natural, tal oposición es innecesaria a menos que el positivismo sea tomado (como lo hace Kelsen, aunque no Hart) para rechazar que la valoración y el juicio moral tengan justificación filosófica o verdad alguna.

Muchas teorías positivistas antes de Hart habían sido modeladas según las ciencias naturales (incluyendo la matemática y la psicológica). The Concept of Law abrió a la filosofía jurídica de habla inglesa a problemas de método en la teoría social descriptiva antes discutidos por Max Weber (en Economy and Society), y mostró, según intentó hacerlo Hart con mayor o menor claridad, que resulta infructuoso procurar una ciencia social general libre 
de valores. Desde entonces, el interés se ha desplazado a colocar a la teoría del derecho en una relación clara con la ética y con una teoría de la política fundada éticamente (por ejemplo, The Morality of Freedom de Hart) o a modelar la misma según la interpretación de expresiones culturales tales como la literatura (por ejemplo, Law's Empire de Dworkin).

Por ejemplo, la crítica de Dworkin al "positivismo" a primera vista parece dirigida a establecer que Hart había descrito erróneamente los tipos de estándares utilizados en la deliberación judicial (Dworkin, "The Model of Rules", en Taking Rights Seriously, 1977). Pero en realidad, las tesis de Dworkin no fueron que los principios difieren de las reglas, sino que ellos son autoritativos no por estar validados por sanción o costumbre (usage), sino por ser moralmente verdaderos (e irreduciblemente distintos de las políticas utilitarias o basadas en otros fines colectivos), y tal teoría del derecho, como prólogo de la adjudicación, es una empresa práctica de "interpretación creativa" que participa en el desarrollo de un sistema jurídico "liberal" que, sin violar la integridad al repudiar demasiados de sus "materiales" (Constitución, leyes y precedentes), ha de tratar a los ciudadanos con igualdad de consideración y respeto. El debate sobre estas tesis plantea interrogantes acerca de si la teoría moral más bien inarticulada de Dworkin es correcta (sound), si la analogía con la interpretación literaria creativa no es una nueva forma de explicación reductiva, y si la pretensión de que el derecho, incluso en los casos difíciles, siempre puede ser identificado razonando moralmente a partir de los materiales jurídicos no es, del mismo modo, una reduccionista visión de la dependencia del derecho respecto de una elección (acto de voluntad) autoritativa racionalmente infradeterminada entre dos o más alternativas razonables aun jurídicamente abiertas.

La obra corriente en la filosofía o teoría del derecho angloparlante contemporánea se resiste a la clasificación como positivismo estricto o como teoría del derecho natural. Una obra que se describe a sí misma como positivista (por ejemplo, The Authority 
of Law de Raz, Inclusive Legal Positivism de Waluchow) o iusnaturalista (por ejemplo, Natural Law and Natural Rights), de hecho se ocupa ampliamente de temas destacados por la escuela "opuesta”. Está ampliamente aceptado que la tarea de la filosofía jurídica se diferencia - aunque deba referirse a ellas - de la ética, de la filosofía política y de una teoría social general que se construye a partir de antropología social e historia comparativa.

La ética indaga acerca de los estándares para el juicio correcto en la deliberación acerca de la elección y la acción, mientras que la filosofía del derecho investiga los modos en los cuales tales estándares se vinculan con las directivas establecidas, por costumbre o por decisión autoritativa, para guiar las acciones de las personas en la comunidad política, y de ese modo, supuestamente, proteger intereses o derechos básicos, distribuir cargas y ventajas equitativamente, y devolverles la posición anterior a las personas tratadas injustamente. De ese modo, la filosofía jurídica va más allá, pero no puede eludir los principales problemas de la ética - problemas tales como el de si las proposiciones morales pueden ser conocidas como verdaderas; si las verdades morales incluyen intrínsecos bienes y razones para la acción más ricos que la kantiana conformidad-con-la-abstracción-universalizantede-la-razón; si el juicio correcto es la maximización de valores como resultado de una elección, y en qué medida la elección es libre y la intención moralmente decisiva-.

Además, la filosofía política investiga acerca de los fundamentos sobre cuya base las personas pueden pretender (y pretenden) tener autoridad para modelar las acciones de una comunidad por la vía de dirigir la conducta individual, mientras que la filosofía jurídica investiga sobre las razones para, y los modos de, establecer tal autoridad y su ejercicio haciéndolos depender de criterios formales (fuente, ámbito de competencia, procedimiento, promulgación y publicidad, integridad adjudicativa, etcétera). De este modo, la filosofía jurídica contribuye a, pero queda involucrada en, los principales problemas de la filosofía política - problemas tales como si la autoridad está justificada por 
el acuerdo; si o por el propósito de beneficio; si los intereses son derechos y los derechos aseguran la igualdad, libertad $\mathrm{u}$ otros beneficios, y si la acción política es correctamente comprendida a partir del modelo de toma de decisiones en economía o en juegos de competencia-.

Además, la teoría social generaliza desde el conocimiento de sociedades particulares y eventos de su historia, mientras que la filosofía jurídica investiga cómo tales sociedades pueden ser sujetos implícitos o portadores de "sistemas jurídicos", y trata a algunos de tales eventos como fuentes de elementos del sistema jurídico. De ese modo, ella se enfrenta con un problema básico de la teoría social general: cómo identificar un tema que pueda seguir existiendo mientras los regímenes y Constituciones cambian y desaparecen; y cómo elegir y justificar conceptos y términos descriptivos y analíticos, dada la variedad de auto-interpretaciones sociales y vocabularios rivales revelados por la etnografía y por estudios históricos comparativos y transculturales.

En línea con la distinción de Bentham entre jurisprudencia expositiva y censoria, la filosofía jurídica frecuentemente es dividida en analítica y crítica. La jurisprudencia analítica se propone considerar la definición del derecho, la teoría del sistema jurídico, el análisis de conceptos jurídicos, tales como deber, transacción e intención, y la teoría del razonamiento jurídico, especialmente en la adjudicación. La filosofía del derecho crítica se propone evaluar el derecho y la obligación jurídica, el contenido sustantivo mínimo de los sistemas jurídicos, aquellas virtudes procedimentales interconectadas en la creación y aplicación del derecho que son llamadas Estado de derecho, etcétera. Pero contra tal división, algunos han alegado (por ejemplo, NLNR) que, dado que crear y conservar los sistemas jurídicos le incumbe a las razones, y como toda razón para la acción presupone y/o propone evaluación(es), cualquier exposición general de los sistemas jurídicos (o del concepto del derecho y del sistema jurídico) debe identificar tales evaluaciones modeladoras. 
Hart y Raz responderían que el análisis descriptivo del carácter del derecho como instrumento puede llevarse adelante sin tener que evaluar los diversos propósitos y usos para los cuales se emplea el instrumento. Pero esta respuesta parece insuficiente, pues el sentido característico del derecho como obligatorio y autoritativo, como su sentido de establecer procedimientos apropiados y exigir juicios justos y fallos basados en la verdad, en sí mismo propone una evaluación y crítica de condiciones sociales alternativas (anarquía, dominación arbitraria). No puede haber una comprensión o análisis adecuadamente cercano de lo que caracteriza a sistemas jurídicos diversos - una exposición que demuestre por qué el derecho merece un lugar en cualquier descripción general de la vida humana social - sin una comprensión de los modos en los que las propias notas características del derecho (incluso cuando han sido manipuladas injustamente) expresan una evaluación crítica de, y una respuesta constructiva afirmativa de valores frente a, los tipos de injusticia o de otra lesión de bienes humanos que son inherentes a la ilegalidad de cualquier especie (análogamente, uno podría entender y describir un argumento sin aceptarlo o aprobarlo, pero no puede entender y describir bien al argumento en general a menos que acepte algunos argumentos como buenos y adopte como normativos para la propia descripción/explicación general los criterios por los cuales puede reconocerse su corrección).

Más y más firmemente, la filosofía jurídica norteamericana y británica reconocen que el derecho es de alguna manera una institución o producto del razonamiento humano, y dirigido al razonamiento humano. En la medida que los filósofos del derecho se esfuerzan por evitar el "reductivismo" (reductivism) - la restricción de estrategias de investigación y reflexión a modelos inapropiados-, ellos reconocen más o menos explícitamente que las leyes y los sistemas jurídicos, al igual que los hombres que son sus creadores y destinatarios, de alguna manera pertenecen a los cuatro "órdenes" con los cuales (como sostenía Tomás de Aquino) tiene que ver la razón humana - a grandes rasgos, natura- 
leza, lógica, moralidad y cultura (Finnis, Aquinas: Moral, Political and Legal Theory) - . Utilizando los símbolos convencionales del lenguaje ordinario, y complementándolos con nuevas convenciones y técnicas, las reglas jurídicas articulan concepciones del orden natural (que la razón no crea, sino que sólo considera), de lógica consistencia e implicación, y, sobre todo, de la corrección e incorrección en la deliberación y acción oficial y extraoficial. Esta articulación por medio de reglas jurídicas es altamente reflexiva: el eslogan kelseniano de que "el derecho regula su propia creación" capta algo de esta reflexividad. Mas aún, incluso las reflexiones filosóficas sobre el derecho (y la naturaleza, la lógica, la moralidad y las técnicas no jurídicas) pueden encontrarse con mucha frecuencia entre los conceptos y términos empleados al crear, interpretar y hacer uso de las reglas, instituciones y procesos jurídicos. Los filósofos del derecho siempre están tentados - aunque hoy en día se esfuerzan más y más por resistir la tentación - a resolver la complejidad resultante a través de la relativa simplicidad de sólo un paradigma u otro.

La "filosofía del lenguaje ordinario" practicada en Oxford en los años cincuenta (con raíces en Wittgenstein) alentó la oposición a los métodos reductivistas. Entre los frutos más importantes de tal estilo de hacer filosofía - apenas una "escuela" de doctrina filosófica - se encuentra Causation in the Law, de Hart y Honoré. Algunas interpretaciones de la causa, en particular las interpretaciones alemanas a partir de Kant, han sostenido que la misma es por movimientos físicos, no pudiendo ser alteradas por los fines del actor u otros estados psíquicos (que sólo son relevantes para imputar culpabilidad o responsabilidad jurídica). Tales interpretaciones de la causalidad humana están modeladas sobre interpretaciones científico-naturales de la causalidad como regularidades, o probabilidades, o alguna propiedad inherente de objetos o sucesos. Algunas otras teorías jurídicas de la causa, en particular estadounidenses, han reducido la "causa fáctica" (cause in fact) a la mínima conditio sine qua non (si no fuera por $\mathrm{C}$, E no habría ocurrido), y aducido que "causa jurídica" es mera- 
mente una construcción de políticas sociales (esto es, políticas morales y/o culturales) acerca de quién tiene la culpa y/o tiene que responder. Contra tales reducciones se yergue la interpretación de Hart y Honoré: la determinación judicial de que el acto o la omisión de alguien ha causado algún hecho y/o pérdida está justificada por consideraciones sustancialmente independientes de conclusiones morales u otras políticas sobre la responsabilidad, y son similares a concepciones científicas, históricas y de sentido común al distinguir lo causalmente relevante como una subclase dentro de la categoría de las condiciones sine qua non. En esta interpretación, el concepto causal central, el de desviación de las condiciones normales, se expande a sí mismo para incluir condiciones culturalmente establecidas, como las expectativas contractuales o los deberes jurídicos; las atribuciones de responsabilidad causal anidan en, pero no son reducibles a, las concepciones de responsabilidad de roles y responsabilidad-deber de reparar, distribuciones de carga de la prueba, criterios y métodos de prueba, y otras consideraciones no causales. La complejidad de una tal interpretación no reductivista refleja la irreducible complejidad de la vida de seres que viven en el mundo natural como sujetos agentes, artífices y creadores que razonan y eligen, y para quienes la "normalidad" se mide por diversas medidas que se toman de cada uno de los cuatro órdenes antes mencionados.

Considérese, ahora, la personalidad jurídica. Algunos han dicho que por cuanto los únicos sujetos genuinos de las relaciones jurídicas son miembros de las especies naturales, los seres humanos, entonces cuando los abogados hablan de otros sujetos de derecho (corporaciones, simples asociaciones, buques, ídolos, etcétera) están hablando de meras ficciones. Otros (por ejemplo, Kelsen) han dicho que el estatus de persona jurídica es simplemente una creación del derecho, que libremente lo confiere o lo deniega, y que la lógica de las reglas jurídicas no deja lugar para atribuirles a los seres humanos una prioridad jurídicamente cognoscible. Pero una exposición no reductivista puede (a) negar que las asociaciones humanas son meras ficciones, (b) reconocer la 
conveniencia de atribuir a las asociaciones e incluso a entes no-humanos el estatus de sujetos de reglas y procesos jurídicos, (c) aceptar que en un análisis meramente lógico de las reglas y relaciones jurídicas, el sujeto humano no tiene prioridad, pero (d) sostener que dado que el verdadero objetivo de guiar la deliberación a través del derecho es proteger y promover el bien de los seres humanos, y dado que esa clase de sujetos está naturalmente constituida antes de cualquier decisión humana, las leyes se desordenan radicalmente como leyes cuando niegan a cualquier ser humano (esclavos, embriones...) la "igual protección de la ley" (como mínimo, igualdad en la inmunidad y estatus jurídico fundamental).

Como lo precedente trata de poner en evidencia el muy debatido problema de definir al derecho, no puede ser resuelto por ninguna técnica puramente "analítica" que aspire a ser neutral y conceptualmente anterior a la toma de posiciones sustanciales acerca de cuestiones debatidas como, por ejemplo, el orden natural y el orden moral. Por supuesto que las definiciones estipulativas y/o las clarificaciones lexicográficas ayudan a la investigación y deberían evitar que se pasen por alto cuestiones discutidas. Pero las definiciones explicativas resumen los resultados de la reflexión filosófica; ellas no son conjuntos o exposiciones de datos lingüísticos o de regulaciones de la reflexión filosófica. En la filosofía jurídica es particularmente fácil ver el valor de la ya mencionada técnica clásica, presentada por Aristóteles, practicada por sus seguidores medievales y recuperada - por no decir completa y consistentemente utilizada - por Hart: se toma como el tema de una definición explicativa el caso central del explanandum (y correspondientemente el significado focal del término que significa tal realidad), y se trata como secundarias y relativamente periféricas, pero de ninguna manera como sin importancia o irrelevantes, las muchas realidades que representan el caso central en una forma diluida, inmadura o defectuosa (y correspondientemente los usos secundarios del término).

Sobre esta base, uno puede (y debería) decir que un sistema jurídico que niega personalidad jurídica y/o fracasa en proteger 
los derechos fundamentales de algunos de sus súbditos humanos no es meramente injusto o inmoral, sino también un ejemplo empobrecido de sistema jurídico. Mas nótese que tal tesis depende de la premisa adicional, ampliamente discutida, de que lo que es considerado como el caso central o el buen ejemplo en un tema de la filosofía social (por ejemplo, jurídica) se establece por referencia a las preocupaciones evaluativas no de los "malos ciudadanos" - que sólo se preocupan por evitar sanciones (como aducían los realistas jurídicos estadounidenses), ni de jueces $\mathrm{u}$ otros oficiales moralmente despreocupados en cuanto tales (como proponía Hart)-, sino más bien de personas que entienden, aceptan y promueven el derecho como una respuesta moralmente motivada y justificada a los males e injusticias de las relaciones humanas no regladas legalmente.

Tales cuestiones de definición y metodología explicativa son cuestiones dentro del orden de la lógica, esto es, del orden racional que introducimos en nuestro propio pensamiento. Algunos de los problemas peculiares de la filosofía jurídica se presentan primariamente dentro de este orden. ¿Cómo difiere el carácter proposicional de las reglas jurídicas del de los principios jurídicos u otros estándares jurídicos (véase Dworkin, Taking Rights Seriously)? ¿Cuáles son los tipos de oposiciones lógicas entre reglas, y en qué medida es posible una contradicción entre reglas en un sistema jurídico (compárese la Teoría pura del derecho de Kelsen con su Teoría general de las normas)? ¿Son todas las reglas de, o al menos reducibles a, un tipo lógico como el de la imposición de una obligación bajo pena de sanción o la autorización hipotética de sanciones (véase The Concept of Law de Hart; The Concept of Legal System de Raz)? Si es así, ¿están correlacionados con las funciones o fines sociales de los diferentes tipos de reglas (véase The Authority of the Law de Raz)? ¿Cuáles son los tipos irreduciblemente distintos de derechos (quizá, reclamo, libertad, poder, inmunidad)? ¿Son los derechos meras construcciones lógicas de, o sombras de, un concepto de deber lógica o explicativamente anterior? ¿Es una libertad (permisión) la mera ausencia de un deber en contra- 
rio, o ella implica una prohibición de alguno de (o de todos) los tipos de interferencia por parte de A en el ejercicio de la libertad de $\mathrm{B}$ y, si es así, ¿implicaría esto siempre o alguna vez que $\mathrm{B}$ tiene un derecho-libertad para hacer lo que no debería?

Tales cuestiones tienen un núcleo irreduciblemente lógico. Pero el progreso en resolverlas exige atención cercana al especial significado y uso de términos, tales como "regla", "obligación", "derecho" y "libertad" dentro de la específica construcción cultural y técnica llamada "derecho". Esta construcción, por su parte, sirve característicamente a ciertos propósitos humanos, y lo hace guiando la deliberación. Una exposición verdaderamente general de él no puede ser limitada a registrar los propósitos, fines y técnicas de una persona, o limitada a reproducir de un modo "desconectado" su discurso "comprometido". Ella debe, antes bien, comprometerse hasta cierto punto en la reflexión sobre el orden moral (que a través de la razón traemos a nuestras deliberaciones en miras a la elección y acción), preguntándose cuándo la acción está relacionada inteligentemente con propósitos humanos básicos y razones para la acción. En síntesis, todas las cuestiones enumeradas en el párrafo precedente exigen la toma de alguna posición sobre el sentido del derecho (point of law). ¿Es lo más esclarecedor considerar al derecho como un instrumento de control social, sean cuales sean los propósitos de los controladores? ¿ $\mathrm{O}$ tal interpretación torna ininteligible mucho del vocabulario y la lógica del derecho? ¿El derecho está para servir ante todo a la libertad, o es la libertad que él sirve (si lo hace) sólo uno entre muchos beneficios fundamentales? Tales cuestiones pueden parecer lejanas desde un análisis estrictamente lógico, pero las respuestas a ellas han demostrado ser necesarias (a pesar de insuficientes) para el análisis de la estructura de los sistemas jurídicos como proposiciones, o contenidos de sentido cuasi-proposicional, interrelacionados .

Los esfuerzos para reducir los problemas de la filosofía jurídica al orden lógico han derivado en notables fracasos: por ejemplo, el intento de Hobbes de explicar la obligación contrac- 
tual por la vía de equiparar ruptura con absurdo lógico (véase NLNR), o la pretensión kantiana de que, dado que la falta de B contradice el uso legítimo de la libertad de A, el uso de la coerción por parte de A (o G) "para impedir" la falta de B debe, "en virtud del principio de no contradicción", ser compatible con la libertad legítima. Como tales fracasos lo sugieren con fuerza, la normatividad del razonamiento práctico y de las normas jurídicas no es reducible a la normatividad de la lógica, sino que descansa sobre la necesidad de medios para, o de respeto hacia, fines básicos (bienes humanos básicos, razones básicas para la acción).

Algunos han tratado los problemas y conceptos morales vinculados con el derecho declarándolos ajenos a la filosofía jurídica, o redefiniéndolos como técnico-culturales y no morales. ¿Afecta la injusticia de una ley su autoridad, validez u obligatoriedad? ¿Es la equidad una cuestión simplemente de interpretación o ella corrige (en miras a la justicia) las intenciones de los creadores de la ley? Las leyes (y contratos) que crean obligaciones, ¿representan nada más que una obligación de pagar la penalidad (o indemnizar los daños) en caso de incumplimiento? Se ha dicho que problemas como éstos serían meramente asuntos de conciencia, moralidad o ética individual. Pero en el propio (consciente) ejercicio de su función judicial como tales, los jueces no pueden evitar tales cuestiones. Y existen otras cuestiones incluso más esencialmente vinculadas con el rol de adjudicación. ¿Es correcto para un juez cambiar el derecho al costo de derribar las legítimas expectativas de un litigante perdidoso? ¿O dejar de lado las políticas deliberadamente adoptadas por una mayoría democrática? ¿Pueden los jueces descansar sobre sus propios conocimientos sin el respaldo, o incluso en contra, de la evidencia válidamente aportada en el caso? Además, existen las responsabilidades sintetizadas en el ideal del Estado de derecho (Rule of Law, Rechtsstaat en alemán): para asegurar que el derecho sea claro, coherente, estable, público, practicable, irretroactivo, general y, sobre todo, respetado en la acción oficial (incluso judicial). ¿Es este conjunto de propósitos y características del ordenamiento jurídico moral- 
mente neutral (como el filo de un cuchillo para cortar), tal como pretende Raz en The Authority of Law)? ¿O el conjunto, considerado como un todo, debe tener el propósito moral de asegurar una relación de justa reciprocidad entre gobernantes (rulers) y gobernados (ruled), por el reconocimiento de la dignidad y los derechos de los gobernados (véase Fuller, The Morality of Law)?

Concluir que tales cuestiones son propiamente partes de la filosofía jurídica no significa tomar partido en el perenne debate sobre si definir al derecho como cualesquiera estándares cognoscibles a partir de fuentes fáctico-sociales (legislación, costumbre, precedente judicial) (Raz, Authority of Law), o más bien como cualesquiera estándares que un juez debería considerar al dictar sentencia (Dworkin, Taking Rights Seriously).

Nos queda que las leyes están manifiestamente en el orden técnico-cultural (orden que a través del razonamiento nosotros traemos al asunto sometido a nuestro poder); ellas son objetos creados por decisión humana como un instrumento de coordinación social. Este aspecto de la positividad del derecho parece estar puesta en cuestión, con razón suficiente, tanto por las teorías (realismo jurídico) que reducen el derecho a una predicción de la acción judicial como por las teorías (por ejemplo, "derecho como integridad" en Law's Empire de Dworkin) que localizan el derecho no en reglas y estándares existentes (considerados como meros "materiales jurídicos"), sino sólo en el momento de decisión por un juez que, en una "interpretación creativa", somete los "materiales jurídicos" a lo que en última instancia es una evaluación moral individual.

Los muchos y variados artefactos del derecho comprenden, en primer lugar, las reglas del derecho mismas. Incluso aquellas reglas que confieren expresión jurídica a una norma moral son verdaderamente leyes positivas y por lo común de una forma artificial: la ley no prohíbe formalmente el asesinato, sino que antes bien define el asesinato como un crimen, añade penalidades, descalificaciones y otras consecuencias jurídicas a los crímenes, y establece que los "crímenes" no pueden ser cometidos. Con 
todo, la mayoría de las reglas jurídicas no son meras reformulaciones de normas morales, sino productos de una decisión social innegablemente creativa. Su autenticidad no es inmediatamente una cuestión de verdad moral, sino más bien de consideraciones de forma, fuente y procedimiento comprendidas en el concepto característicamente jurídico de validez.

La mayoría de los demás artefactos jurídicos pueden ser clasificados bajo otro término característicamente jurídico: instituciones. Las instituciones jurídicas no sólo incluyen organismos públicos, tales como tribunales y legislaturas, sino también tipos de construcciones jurídicas que involucran grupos de reglas (contrato, venta, propiedad, sociedades, crimen, delito...) y ejemplos específicos de tales tipos, instituidos deliberadamente para el logro de su consecuencia jurídica (así, una Constitución, contrato o sociedad en particular, pero no un delito o crimen en particular). $\mathrm{Y}$ tales artefactos deben ser distinguidos de cualesquiera documentos empleados para crearlos o registrarlos. Es obvio que la descripción y explicación de tales artefactos sería compleja incluso si el orden técnico-cultural pudiese ser cerrado a los órdenes de la naturaleza, la lógica y la moralidad. Pero no puede serlo, y algunos de los debates más intensos en la filosofía jurídica contemporánea tienen que ver con la moral y con otros fundamentos (por ejemplo, causa) de las instituciones jurídicas del crimen, daño (delito), contrato y propiedad (por ejemplo, Fried, Contract and Promise).

Otros artefactos jurídicos incluyen definiciones. Mientras que el propósito de la definición en filosofía jurídica es sintetizar una comprensión y explicación de los casos centrales (y no centrales) y de los sentidos focales (y secundarios), el propósito de la definición en derecho es más bien asignar objetos y tópicos de la vida humana social a clases unívocas para los propósitos de una regla dada (por ejemplo, gravar "barcos"). Otro artefacto jurídico es el conjunto de reglas de inferencia que establecen presunciones para el juicio jurídico sobre los hechos. Las definiciones y las reglas de inferencia se encuentran en la práctica jurídica- 
mente peculiar de considerar que $\mathrm{X}$ es un ejemplo de $\mathrm{Y}$, con independencia de que él sea considerado o no una $\mathrm{Y}$ en la lógica ordinaria o en, digamos, el discurso científico, histórico o moral.

Muchas cuestiones discutidas en la filosofía jurídica contemporánea se presentan en el debate sobre la interpretación de Constituciones, leyes, sentencias y otros instrumentos (documentos) y construcciones jurídicos. Los intérpretes jurídicos, ¿deberían encontrar y seguir los compromisos originalmente asumidos en las elecciones e intenciones moralmente significativas de sus creadores? ¿O ellos deberían dar al lenguaje utilizado - un conjunto de objetos convencionales empleados para crear un objeto cultural nuevo e independiente (la Constitución, la ley de..., etcétera) - un significado y efecto nuevos de acuerdo con nuevas comprensiones convencionales del lenguaje? ¿No están el acto de legislación y el acto de interpretación judicial (si bien inmediata y directamente ejercicios de una técnica cultural) limitados en su plasticidad o maleabilidad no sólo por otras convenciones, sino también por el carácter naturalmente dado (giveness) de los actos humanos, por los requerimientos de coherencia lógica, y por la significación moral de todo acto humano?

Durante los años ochenta y noventa, algunos teóricos, especialmente en los Estados Unidos, sostuvieron que todas las reglas jurídicas — no sólo aquellas contenidas en textos autoritativos, tales como una Constitución o una ley, sino también aquellas transmitidas por las formas cuasi-consuetudinarias de adjudicación del Common Law - son esencialmente indeterminadas, y con ello son meramente mantos para el ejercicio de poder discrecional y elitista. Esta tesis del movimiento de Critical Legal Studies (Unger, The Critical Legal Studies Movement) ha sido extendida a tesis "postmodernas" y "deconstructivistas" que por vías análogas proponen negar la inteligibilidad estable de los textos y estándares jurídicos. Pero las tesis de la última clase claramente se refutan a sí mismas (self-refuting), puesto que su propia afirmación y defensa exige que las declaraciones hechas por sus proponentes tengan una inteligibilidad estable y determinada. Y las tesis crí- 
ticas "originales" sobre la indeterminación dependían para gran parte de su plausibilidad de una equivocación acerca de "indeterminación", esto es, un error en distinguir "indeterminado" de "sub-determinado" o "no completamente determinado". Es característico de las reglas jurídicas que ellas resuelven algunas (quizá realmente muchas) cuestiones para el propósito práctico de una vida coordinada, pacífica y justa en la comunidad política, dejando algunas otras cuestiones sin alguna respuesta clara. Después de todo, las cuestiones que así se dejan sin resolver no necesitan presentarse en la práctica, o si ellas lo hacen alguna vez pueden ser resueltas, incluso resueltas justamente, sin tener que recurrir a estándares o procedimientos jurídicos.

La dependencia de la moralidad (como así también de la naturaleza, la lógica y la técnica) que tienen el derecho y el razonamiento judicial, acoplado con el escepticismo moral o ético ampliamente profesado en la cultura angloparlante contemporánea, inclina a ciertos teóricos a una forma de "pragmatismo" que trata las cuestiones principales de la filosofía jurídica como cuestiones más allá de la capacidad de respuesta de la razón, y se contenta a sí misma con un eclecticismo más o menos injustificado y sin principios (véase, por ejemplo, Posner, The Problems of Furisprudence). Tal escepticismo ha sido, parece, una fuente de la popularidad del positivismo jurídico en la primera mitad del siglo XX. En la medida que esto es así, queda para los así llamados "teóricos del derecho natural" afirmar, explicar y defender la racionalidad de la empresa jurídica en su conjunto. Al así hacerlo, esos teóricos no necesitan, y por lo común hoy no lo hacen, repetir el tipo de afirmación característica de los "racionalistas" de los siglos XVII y XVIII que de manera optimista y de alguna manera acríticamente exageraron el marco de las cuestiones que tienen una respuesta correcta racionalmente determinada con independencia de las elecciones jurígenas de las particulares comunidades y de sus representantes. Una cosa es reconocer tal exageración cuando ocurre, y otra bien distinta es negar que existen derechos humanos definidos e incluso sin excepciones, 
articulados en reglas, estándares e instituciones jurídicas que son la columna vertebral de todo sistema jurídico llamada apropiadamente, sin calificativos, "el derecho de esta comunidad".

Cada tesis en la filosofía del derecho, como en cualquier otra rama de la filosofía, debe satisfacer la precondición de que la proposición que afirma sea totalmente consistente con la elección razonable del filósofo de investigarla, afirmarla y defenderla argumentativamente, y con las condiciones naturales, racionales, culturales, morales, familiares y políticas que hacen posible y facilitan, antes que obstruyen, tal investigación, afirmación racional y defensa intelectual honesta. 


\section{LEY NATURAL Y DERECHOS NATURALES, 30 AÑOS DESPUÉS*}

Han pasado ya, en realidad, 45 años desde que el libro tuvo su comienzo con la invitación a escribirlo y la cuidadosa especificación de su título de mi mentor y colega H. L. A. Hart (cuento esto al comienzo del nuevo Postscript del libro, pero ustedes, en el gran mundo de habla española, ya lo sabían por el notable "Estudio preliminar" a la traducción de Cristóbal Orrego). Y han pasado unos 40 años desde que el plan del libro adquirió la estructura de algo así como unos eventuales trece capítulos: diez que identifican los bienes humanos que pueden realizarse únicamente mediante instituciones de derecho positivo, y que explican las exigencias de la razón práctica que sólo esas instituciones pueden satisfacer; flanqueando esos diez capítulos, por un lado, con dos capítulos preliminares para situarlo en el contexto académico de la teoría legal positivista, auto-configurada como ciencia social descriptiva y pretendidamente avalorativa, y en el contexto más particularizado de los malentendidos y las objeciones usuales a la teoría del derecho natural, y por el otro lado, con una capítulo final que muestra cómo la teoría desplegada en los diez capítulos centrales precisa de, y puede ser abordada con, una mayor hondura explicativa, en respuesta a las cuestiones planteadas por reflexiones teóricas acerca de nuestra situación existencial fundamental, y por reflexiones prácticas acerca del sentido último de todo desarrollo humano y de toda pérdida humana.

Esos 45 años, tal como fueron vividos por el autor y la mayoría (¡no todos!) de los lectores del libro, han sido años de relativa prosperidad y paz, de instituciones políticas, económicas y legales mayormente estables, de sustancial libertad para investigar y pu-

\footnotetext{
* Traducción al castellano de Pilar Zambrano.
} 
blicar, y de creciente habilidad para adquirir información y para viajar por trabajo y por placer. La amenaza estructural profunda del balance de terror generado por la política de disuasión nuclear ha pasado y, por ahora, se encuentra substancialmente disipada u olvidada. Al mismo tiempo, y no menos en los cinco primeros años de esos 45, las normas sociales y las instituciones típicas de una civilización a grandes rasgos cristiana y humanista, especialmente las normas e instituciones sobre el matrimonio y la familia, la protección del no-nacido, y la educación formal de los niños mediante establecimientos educativos, y la informal a través de los medios de comunicación social, han sufrido una disipación revolucionaria. Las estructuras económicas, educacionales y legales han asimilado concepciones de la igualdad y de la titularidad de derechos que son despectivas de la sabiduría tradicional acerca de las necesidades y de las clases apropiadas del hogar. El consecuente colapso en la tasa de natalidad hasta niveles completamente incompatibles con la sustentabilidad de un pueblo se ha topado con el desconcierto de las clases dirigentes y con la evasión de las consecuencias inmediatas mediante la admisión de pueblos bien diferentes, cuyo arribo y asentamiento preanuncia en algunos casos obvios, en el mediano y largo plazo, desastres de rupturas sociales y políticas, guerra y ruina.

Pero cuando el libro estaba siendo concebido y escrito, el despliegue de esos efectos estaba aún algunas décadas por delante. Lo que domina la concepción y la composición del libro, en una extensión que en buena medida quedó implícita, son las revoluciones espirituales que se extendieron por la vida política, eclesiástica y familiar de estas pacíficas y ricas sociedades de los años sesenta, alcanzando una suerte de tormenta en la segunda mitad de esa década con las revueltas estudiantiles de 1967/8, les évenements de Mai 1968 que sacudieron al gobierno de Francia, y la rearticulación de la enseñanza cristiana sobre sexo y matrimonio en Humanae Vitae en julio de ese mismo año, un acto doctrinal casi asfixiado por una resistencia y un rechazo internos sin paralelos (en ciertos sentidos) en la historia cristiana, un cuasi-cisma 
(quasi-schism) que, en sociedades como la norteamericana, inmediatamente hizo trizas la influencia del catolicismo en la política, donde había sostenido una red de instituciones cívicas legales y eficaces, protectoras de la moralidad pública, de los derechos del no-nacido, la permanencia y los privilegios del matrimonio, y demás. La estudiada marginalización y desatención de estas agitaciones y tensiones espirituales por parte del libro está en parte compensada por su aspereza declamatoria, en varios pasajes, acerca de la amenaza nuclear disuasiva de infligir en los adversarios vastas masacres de no-combatientes y en represalias finales post-derrota: estos juicios se exponen como el fruto principal de la crítica del libro a las teorías éticas que denomina consecuencialistas o utilitaristas. Pero las herederas teológicas de estas teorías, que se proponen con el nuevo nombre de "proporcionalistas", fueron en gran medida pensadas para legitimar el abandono de las normas sexuales características de la cristianidad desde el comienzo, normas que el libro afirma sólo implícitamente y por medio de citas de trabajos míos donde se las defiende. Como esta defensa fracasa en comprenderlas precisamente como lo que en verdad son - implicancias del bien humano básico del matrimonio, el bien humano que el libro también fracasa en identificar como distinto de sus aspectos constitutivos, la procreación y la amistad - la decisión estratégica de no decir nada directo acerca de las mismas tuvo el buen efecto secundario de no decir nada prematuro o erróneo sobre ellas.

He estado diciendo que el libro fue compuesto y tuvo su recepción en una suerte de oasis de paz y prosperidad, cuyos habitantes, aunque desde temprano involucrados en políticas (en el momento de la concepción del libro) que polucionarían algunas de sus reservas naturales y acabarían por agotar otras, no habían comenzado realmente a atender a los efectos debilitadores de esas políticas, al menos no públicamente o en conversaciones educadas (o cuando si les prestaron atención, a seguir los efectos hasta sus causas). Pero el oasis, o el espejo de luz, estaba filosamente enmarcado por la negrura de la violencia espeluznante de 
la guerra de 1939 y 1941 a 1945, en parte intra-civilizacional y en parte interracial, y por el apocalipsis nuclear, cuya inminencia potencial siempre presente estaba simbolizada por las estaciones radares esparcidas a lo largo de la costa este de Inglaterra, puestas ahí para advertirnos durante cuatro minutos acerca del final. En Malawi, donde fu escrita gran parte del libro, la sensación de oasis o de un viñedo floreciendo hermosamente sobre las laderas de un Vesuvio murmurante, siempre capaz de entrar en erupción y enterrar todo durante la noche, estaba simbolizado por la presencia de colegas amigos expatriados, recientemente removidos de la enseñanza del derecho en una Uganda velozmente absorbida por el torbellino de la autocracia vil y salvaje de Idi Amin. La autocracia de Malawi no era ni vil ni salvaje, y descendió al crudo asesinato político sólo en los años después de que me fui con el libro completo en mis valijas. Pero el juicio corrupto por traición de antiguos altos miembros del régimen, un proceso al que asistí diariamente con mi clase de alumnos del último año de la carrera de derecho de Malawi, acabó en el ahorcamiento del inocente y en el indulto (reprieve) del moralmente culpable, y puso suficientemente en claro cuáles son las delicadas pre-condiciones del Estado de derecho y de la debida libertad de comunicación, y las muy malas consecuencias de la deficiencia de estas pre-condiciones, limitaciones y libertades.

En el mundo de las reflexiones sobre la razón práctica donde se ubica el texto del libro, los años de su concepción eran un jirón de corrientes cruzadas. En algunos elementos principales recordaba a las corrientes cruzadas en el alma y en el trabajo del filósofo práctico más influyente de Inglaterra, Jeremy Bentham. Desde el comienzo hasta el final de su vida laboral (esto es, de 1776 a 1832), escribiendo 2000 palabras por día (todos los días), su hedonismo psicológico determinista osciló entre el principio moralista extremo de que "uno debe actuar siempre maximizando los intereses (el balance de placeres y dolores) (pleasures net of pains) del mayor número de personas y, de otra parte, el extremo a-moralismo del principio de que uno actúa - que todos 
actúan - siempre para maximizar su propio interés (el propio balance de placeres). Mi genial y estudioso colega filosófico en la Universidad de Oxford, John Mackie, enseñó en su libro Ethics, ampliamente leído, que no hay valores objetivos, ninguna verdad moral de ningún tipo y luego, sorpresivamente, en la segunda mitad del libro, enseñó ique la ética puede inventarse-construirse! El emotivismo y el prescriptivismo, la autollamada "meta-ética", que dominó en la filosofía moral inglesa en los años cuarenta y cincuenta, y que estaba cediendo en los años sesenta de cara a una crítica académica efectiva, pero no lo suficientemente profunda y meticulosa, cuya eficacia fue luego bastante acrecida por el nuevo deseo de muchos de hacer una crítica moral a lo que quisieron denominar los crímenes de guerra de américa en Vietnam - y desde esos años, y el moralismo no apologético de la Teoría de la justicia de John Rawls (1971)—, la filosofía reinante en los seminarios de graduados en el mundo donde me he movido ha sido una que, con poco o ningún esfuerzo de justificación o explicación profunda, toma a los predicados y a las propocisiones morales como capaces de ser ciertamente verdaderos. Pero esto afectó poco las actitudes filosóficas que perviven en las escuelas y en las mentalidades de los niños de colegio y de los estudiantes, para quienes es axiomático que un "juicio de valor" de cualquier tipo es "subjetivo", incapaz de ser verdadero - un axioma psicológicamente compatible, como lo muestra la experiencia de escuchar a la gente joven, que afirma fervientemente que la violación y el racismo, y quizá la tortura, son males morales-.

En los márgenes de este mundo, aunque por supuesto en el centro de los mundos de vida de mucha gente joven de otros sitios, estaban el "estructuralismo" de Claude Lévi-Strauss, el etnógrafo, y de Noam Chomsky, el lingüístico; las nociones neomarxistas de que la naturaleza humana se puede transformar mediante una revolución emancipatoria de un tipo que se mantiene audazmente sin especificar; el intento de corta duración de Richard Posner, en 1979, de reemplazar la ética utilitarista y otras corrientes con su economicismo. Mi abordaje a este conjun- 
to relativamente marginal de corrientes diversas quedó mayormente sin registrar en mi bibliografía, aunque mis Collected Essays incluyen, sin embargo, algunos ensayos publicados y sin publicar de la década anterior a Natural Law and Natural Rights. Su núcleo, que sería ampliamente extendido en Fundamentals of Ethics (1983), está substancialmente resumido en el texto y en la nota final del capítulo III.5 (“"Objeto de deseo» y «objetividad»”) de Natural Law and Natural Rights, precediendo de forma inmediata la breve sección acerca de auto-refutación. La significación más amplia de la auto-refutación en filosofía me ha llamado la atención. El parágrafo final del ensayo "Legal Philosophy: Roots and Recent Themes", que incluí en 1988 en una colección china de filosofía inglesa y americana (ahora el ensayo 6 en el volumen IV de mis Collected Essays), es simplemente éste (173):

Toda tesis de filosofía del derecho, como en cualquier otra rama de la filosofía, debe satisfacer la precondición de que la proposición que se afirma sea completamente consistente con la elección razonable del filósofo de investigar, afirmar, y defender argumentativamente, y con las condiciones naturales, racionales, culturales, morales, familiares y políticas que hacen posible y que facilitan, en lugar de obstruir, dicha investigación, aserción racional y defensa intelectual honesta.

En la década que precedió a NLNR, estaba interesado en una implicancia todavía más amplia de la misma línea de pensamiento sobre la consistencia auto-referencial. En un trabajo sobre la "Libertad de expresión", escrito en 1970 para el seminario de Oxford de Ronald Dworkin sobre los derechos (muy poco tiempo después de la llegada de Dworkin a Oxford como sucesor de Hart, y algunos años antes de que él y yo, con Raz, comenzáramos seminarios conjuntos) incluí una exploración o una prueba de esta implicación. El trabajo se publicó, ahora por primera vez, como el ensayo 18 en el volumen I de mis Collected Essays (302-3), y la sección central que les leeré articula mucho de lo que son los fundamentos de NLNR, aunque nunca se expresaron de este modo en el libro. 
Con la noción del bien, mi bien, tu bien, entramos en la "región de los principios". Alguna gente diría que entramos en el dominio de la ideología. Distinguen entre: (a) la ciencia política y legal, que ofrece explicaciones descriptivas o fácticas de las instituciones políticas y los sistema legales; (b) la ideología, que ofrece recomendaciones sobre los fines ideales que la actividad política y la organización legal debería proponerse, y (c) filosofía política y legal, que ofrece clasificaciones y análisis de los términos, afirmaciones y argumentos de los científicos e ideólogos. Pero esta pieza ortodoxa de botánica intelectual (que transcribí de la introducción de A. M. Quinton a Oxford Readings in Political Philosophy [1967]), es superficial y engañosa. Antes de la denominada explicación fáctica y descriptiva de los fines ideales está simplemente la actividad de hacerse preguntas sobre la vida del hombre en la sociedad política. Las preguntas no presuponen nada excepto un deseo de hallar explicaciones correctas en lugar de explicaciones equivocadas de los hechos, y esquemas de acción claros en lugar de esquemas obscuros. Pero la satisfacción de este deseo depende de algo más que del mero desear. La consecución de la verdad y de la opinión razonable tiene condiciones. Uno no puede alcanzar la verdad y lo razonable si no entiende la propia compostura psíquica y las trampas que pone al pensamiento racional acabado, salvo que uno esté dispuesto a imponerse las disciplinas necesarias del aprendizaje, la reflexión, la verificación, y a rechazar el parti pris y el amour prope [la parcialidad y el amor propio]; a menos que uno se involucre en la discusión racional con sus amigos, o haya experimentado las exigencias de la discusión oral y pueda reproducirlas en su propio debate; a menos que las condiciones económicas, sociales, y políticas en las cuales uno trabaja le brinden ocio y descanso del trabajo físico duro, y la información necesaria para hacer juicios ajustados sobre la naturaleza humana y la sociedad; y (pero esto habrá agotado mínimamente la lista de precondiciones) salvo que uno esté equipado con las habilidades lingüísticas (conceptuales) necesarias para 
concebir, sino completar, el proyecto de alcanzar la verdad y la opinión razonable sobre la vida humana en la sociedad política.

Por ello, como sea que se defina la filosofía política y legal, la actividad de continuar la filosofía política como un proceso de cuestionamiento racional dependerá de condiciones fácticas de contexto social, lenguaje, educación, realización económica, y una cierta medida de estabilidad social y libertad política. Ahora bien, la proposición que acabo de expresar no es una proposición dentro de las explicaciones descriptivas o fácticas de las instituciones políticas y actividades de la ciencia política; va más allá de las instituciones que puedan existir y, por sobre los hallazgos empíricos de la teoría política, expresa algunos principios políticos necesarios en virtud de las características empíricas de la naturaleza humana, para animar a la realización de al menos un bien importante. Más aún, la proposición de que en todo el mundo es tan importante alcanzar la verdad en lugar del error y la claridad en lugar de la confusión, no es una recomendación ideológica de algún "fin ideal" inventado. En todo cuestionamiento y discusión racional está implícita la afirmación del valor o el mérito (worth) o el bien de la verdad y la claridad; esta afirmación no es de un "concepto esencialmente discutido", pues molestarse en cuestionar o debatir racionalmente la afirmación implicaría afirmarla con los propios actos, si no con las propias expresiones.

Ahí, por supuesto, se puede ver un despliegue explícito del argumento de la auto-refutación por inconsistencia performativa. El trabajo del seminario continuó.

Esto no quiere decir que alcanzar la verdad y la claridad sobre el derecho o la política (o sobre la cáscara de estos asuntos) es el mayor bien que uno puede procurar, o que la sociedad debería organizarse de forma de sostener a una elite contemplativa - aunque ésta es la conclusión a la que llegó Aristóteles-. Después de todo, aun dentro de la esfera de la actividad estrictamente intelectual, el valor de alcanzar la verdad y la claridad es tan evidente como el valor de compartirla con mis amigos. Al fin y al cabo, el rango valioso de bienes de amistad que uno qui- 
siera compartir con sus amigos es más amplio que el compartir búsquedas y logros intelectuales: no hay necesidad de desarrollar este punto aquí.

Pero el fenómeno de la amistad nos recuerda el gran problema que subyace a todas las discusiones sobre derechos humanos. ¿Por qué tenemos deberes hacia nuestro amigos? (pues si nosotros no tenemos deberes de justicia, ellos no tienen derechos en ningún sentido interesante). Así, para ser un buen amigo, uno debe amar el bien de sus amigos, su desarrollo y su consecución, como si fuera el propio bien. Más aún: ¿por qué tengo un deber hacia mis amigos en casos donde ayudarles pone en peligro mi propio bien? A fortiori, ¿por qué tengo deberes hacia aquellos que no estaría dispuesto a llamar mis amigos? La pregunta es particularmente precisa, por supuesto, para alguien como Aristóteles, para quien el mayor bien es la contemplación racional y la discusión, de la cual sólo el filósofo y sus amigos filósofos son capaces: no está claro que el bien de aquellos que son intelectualmente incapaces de participar en esta actividad debería contar contra el bien de los que sí pueden hacerlo.

A la pregunta "¿por qué debería ser justo respetar el bien de mi amigo?" se han desarrollado recientemente tres líneas de respuesta. La primera es la utilitarista, que pretende que es evidente que uno debería procurar la utilidad, la mayor felicidad del mayor número. Pero, como dice Mill al final de su utilitarismo, el principio de utilidad o de la mayor felicidad... es una mera fórmula lingüística que carece de significado racional salvo que la felicidad de una persona, que se supone igual en la escala, cuente exactamente tanto como la de otra.

El problema que está abordando, significado por "carece de significación racional", es la indeterminación creada, por necesidad lógica, por los superlativos conjuntos como - "la mayor felicidad del mayor número"- ilimitados por una medida como la escala (rate). ¿Quién gana el premio por "escribir el mayor número de poesías en el más corto tiempo y a la mayor velocidad”? ¿"A”, que luego de una hora presenta tres poesías de cinco versos; o 
"B", que luego de una hora presenta tres poesías de diez versos; o " $\mathrm{C}$ ", que luego de un día presenta seis poesías de doce versos...? La solución que ofrece Mill es una orden dirigida a cada uno de nosotros cuando deliberamos sobre qué elegir; "considere la felicidad de cada persona como de igual valor a la de toda otra persona". Pero la pregunta que le estábamos haciendo a Mill era “¿Por qué no debería mi felicidad contar, para mí, más que la tuya o la de cualquier otra persona?". Bueno, Mill enfrenta esta pregunta en la nota a pie que sigue a la oración que cité. $\mathrm{Su}$ respuesta es una suerte de juego de palabras, un subterfugio o una serie de subterfugios: "iguales cantidades de felicidad son igualmente deseables, ya sea sentidas por la misma o por diferentes personas" - para cuya explicación Mill ofrece: "Pues «felicidad» y «deseable» son términos sinónimos". Pero de vuelta: ¿para quién son "iguales cantidades", e "igualmente deseable"? ¿Y son diez unidades "sentidas" por una persona "la misma cantidad que" e "igualmente deseable que", diez unidades sentidas por diez personas en la escala de una persona? Nadie es engañado por el intento de Mill de romper con enredos el círculo del amor propio, el propio deseo - de cada uno de nosotros - de la propia felicidad.

Por ello, una segunda línea de respuesta a “¿Por qué debería respetar el bien de otros?" ha sido desarrollada más recientemente apelando de forma directa al amor propio. Philippa Foot argumenta que no se le puede ofrecer ninguna razón a un hombre para mostrarle que debe ser justo, excepto que es por su propio beneficio, que le será provechoso. ¿Pero no puedo advertir que mi injusticia, si la realizo con suficiente argucia y camuflaje, bien puede pagar con generosidad, y que mi respeto por la justicia puede conducirme a un desastre irrevocable - la muerte - y el fin de todo provecho? En cualquier caso, el tipo de respuesta de Foot no responde al sentido de la pregunta original, que preguntaba precisamente qué tipo de fundamentos racionales existen para actuar en contra de la expectativa de sacar algún provecho personal. Quien hace la pregunta debe tomarse por alguien que 
advierte, y que está perplejo por, ese tipo de experiencia humana, donde el interés compite con otras exigencias que recaen sobre el propio obrar: que advierte y le provoca perplejidad, por ejemplo, que es necesario para el propio bienestar que uno tenga amigos reales, pero que las relaciones cultivadas por el propio bienestar no sean amistades reales.

De vuelta, entonces, del amor propio al desinterés, que se ha convertido en la tercera línea de respuesta recientemente desarrollada, sin el beneficio del pretensioso petitio principii y subterfugio de Mill sobre lo "deseado", "deseable" e "igual", en respuesta a la pregunta "¿por qué debería, en justicia, respetar el bien de otros?". Se dice que no tengo ningún fundamento racional para preferir mi bien al de cualquier otro: la única diferencia entre mi bien y el tuyo, dada nuestra igual humanidad, es mi mera identidad y la tuya, y eso no provee ninguna razón para que yo procure mi bien a expensas del tuyo, o viceversa. Pero este argumento prueba demasiado, pues prueba que debería respetar tus derechos; también prueba que no debería competir contra ti por ningún premio o recurso escaso, ni tú contra mí, y que no soy más responsable por mi padre anciano o por mis hijos que por cualquier otra persona en el mundo - lo que es absurdo-. Algunas formas de auto-preferencia son justas, aunque otras no. ¿Pero cómo sabemos cuáles? ¿Y por qué debería importarnos?

A estas preguntas, el trabajo para el seminario de 1970 ofrece la siguiente respuesta, que pueden encontrar, sintetizada y ya no ofrecida como puntualmente la mía, en la p. 108, capítulo V.4 de NLNR (pp. 138-9 de Ley naturaly derechos naturales). Esto es lo que dije en 1970:

Me parece que la respuesta a la pregunta “¿qué formas de autopreferencias son justas?" sólo puede hallarse adoptando el punto de vista de alguien que está fuera del campo de juego en el que tú y yo nos vinculamos mutuamente mediante acciones, reacciones y pasiones; alguien que se supone que contempla por igual el bien de cada persona involucrada en este campo de juego. Para usar la cruda terminología psicologista hedonista de 
Mill: se puede suponer que tal observador desea que cada hombre en ese campo "sienta" la "misma cantidad de felicidad". Desde tal punto de vista, algunas formas de competencia dentro del campo de juego pueden ser la mejor forma de beneficiarnos a ambos - aunque algunos ganarán y otros perderán en la pugna por el premio como tal-, pues todos pueden ser fortalecidos y vigorizados por la pugna. Por lo cual tal observador consideraría justas aquellas formas de auto-preferencia, de esfuerzo por ganar, que no dejasen a los perdedores en peor estado que en el que estarían si no hubiere habido ninguna competencia. Tal observador también podría percibir las áreas de responsabilidad que cada persona debería asumir en el campo de juego para que todos se beneficien - pues si cada persona toma lo ancho del mundo como su parroquia, el esfuerzo de cada uno se dispersará tanto que nadie se beneficiará-.

Pero tú y yo estamos en el campo de juego. ¿Por qué debería importarnos adoptar el punto de vista del observador, especialmente si somos aptos y fuertes y podemos ganar competencias con un juego limpio, o hacer trampa y hacernos con la nuestra? En principio, podría haber dos respuestas disponibles para esta pregunta. La primera es que quizá el observador no consideraría justo que, a la larga, nos salgamos con la nuestra, y tomaría medidas para recompensar con justeza por nuestros triunfos mal habidos. La segunda respuesta está más cerca a la clase de experiencia que dije que Foot no había considerado suficientemente - la experiencia de la amistad que Aristóteles analizó de modo maravilloso en los libros VII y IX de la Ética-. Amar a un amigo es desearle el bien y valorar su bienestar y de cualquier cosa en la que haya puesto su corazón. Pero si es tu amigo, habrá puesto su corazón en ti, por lo cual deberías valorarte a ti mismo por su bien. Y si es el amigo de $\mathrm{P}$, tendrá el bien de $\mathrm{P}$ en su corazón, de forma que no será un amigo real de tu amigo a menos que tú también valores el bien de $\mathrm{P}$ por el bien de tu amigo. Por supuesto, esto no puede ramificarse más allá de un círculo cerrado de amigos. Más aún, no hay ninguna razón, por cierto ninguna razón en justicia, 
por la cual yo debería preferir el bien de mi amigo a mi propio bien, por no hablar del bien del amigo de mi amigo.

Pero supongan, si esto fuera posible, que soy amigo del observador del campo de juego, y tengo razón para valorar su amistad por sobre cualquier otra cosa, y para creer que puso su corazón en el bienestar de todos los que están en el campo de juego por igual. Entonces tendría razón suficiente, so pena de perder su amistad que es mi mayor bien, para adoptar su punto de vista y considerar necesario, para respetar el bien de todos los que están en el campo en la medida y en los modos en que (hasta donde yo pueda ver) él, el observador que también tiene mi bien en mente, querría.

Recapitulando: a la cuestión “¿cómo sé cuáles son mis deberes en justicia?" está disponible la respuesta en la cual Platón concentró la totalidad de su filosofía política (aunque yo solamente intenté desenredar un único hilo): Dios es la medida. Y a la pregunta "¿Por qué me debería de importar esta medida, qué es lo que la hace obligatoria?", ahora está disponible la respuesta a la que el análisis de Aristóteles de la amistad y la contemplación apunta pero no alcanza (pues para Aristóteles, como dice con gran simplicidad, Dios es demasiado remoto para ser mi amigo o el objeto de mi contemplación) - la respuesta de que Dios es mi mayor bien, y el mayor bien de todos, sean o no capaces de filosofar; y tiene en su corazón el bien de todo hombre por igual-.

Aquellos de ustedes que conocen Natural Law and Natural Rights verán que los elementos de esta línea de pensamiento (tanto la interrogación como las respuestas) están dispersas y redistribuidas a lo largo del libro, en parte en la p. 108 (como mencioné), pero en parte también en las discusiones posteriores sobre la amistad y nuestra participación en el juego divino. En mi trabajo posterior, la noción de adoptar el punto de vista del observador imparcial es enteramente reemplazada por la regla de oro considerada como una implicancia del amor al prójimo como a uno mismo, y más básicamente, como el principio maestro de la moralidad. Ese principio maestro, cuya ausencia de NLNR comento 
(y trato muy brevemente de enmendar) en la sección 4 del Postscript (pp. 419-20) y más adecuadamente en el postscript al capítulo V.1, pp. 450-452:

El punto señalado en la sección 4 [de este Postscript] era que este capítulo no identifica la unidad y la explicación inteligible de los varios principios de la razonabilidad práctica que correctamente identifica. Esa identificación se basa en un método dialéctico...: atender a lo que los filósofos serios concibieron como principios morales maestros. Lo que falta es el principio moral maestro respecto del cual el resto de las exigencias morales son especificaciones. El ensayo I.14, p. 215 (1992a: "Natural Law \&Legal Reasoning") se avoca a ese principio:

El pensamiento moral es simplemente pensamiento racional en toda su extensión, integrando las emociones y los sentimientos, pero sin ser desviado por éstos. El principio fundamental de la racionalidad práctica es: toma como premisa al menos una razón básica actuar, y síguela hasta el punto en que de algún modo puedes actualizar ese bien con tu acción. No actúes sin sentido. El principio fundamental del pensamiento moral es simplemente la exigencia de ser completamente racional: en tanto esté bajo tu poder, no dejes que nada, excepto las razones básicas para actuar, configure tu razonamiento práctico cuando encuentras, desarrollas y usas tus oportunidades para procurar la realización humana a través de las acciones que has elegido. Sé enteramente razonable 1. La frase de Aristóteles ortos logos, y la recta ratio, recta razón, debería ser simplemente entendida como "razón no-obnubilada", no desviada por emociones y sentimientos. Y entonces, la razón no-desviada y la voluntad moralmente buena están guiadas por el primer principio moral: que uno debería elegir (y querer) las posibilidades, y únicamente las posibilidades, cuyo deseo es compatible con la voluntad de que toda persona humana se realice en todos los bienes humanos básicos, el ideal de la realización humana integral.

Aun este pasaje fracasa en expresar una premisa maestra: cada uno de los primeros principios prácticos escoge y nos diri- 
ge hacia, un bien que identifica, en su formulación inicial y no completamente formulada, como un bien "para mí y para cualquier otro como yo". Con la reflexión eventualmente se llega a comprender la verdadera extensión y sentido del "cualquier otro como yo": cualquier persona humana. La realización (el desarrollo) es tan buena en y para cualquier persona humana como lo es en y para mí; y lo mismo es cierto para la realización de cada uno de los aspectos básicos de la realización (los bienes humanos básicos). Por eso la razón no-desviada por motivaciones subracionales nos dirige hacia la realización de todas las personas humanas en todas las sociedades.

Este desarrollo no es un objetivo, sino un ideal de la razón. Las exigencias generales más específicas de la razón práctica, enumeradas y discutidas en el capítulo, especifican los modos de no estar abierto a la realización humana integral. Estas exigencias de ningún modo excluyen la priorización de uno mismo y de quienes dependen de uno, en el ámbito familiar, contractual, político y demás. Exigen, más bien, que la priorización proceda sobre la base de la razón, y no sobre la base de preferencias emocionales en cuanto tales. Lo que contienen esas palabras "en cuanto tales" está articulado en el conjunto de las exigencias básicas de la razón práctica. Para una reformulación de los principales elementos de este capítulo entero, en términos de especificación del principio moral maestro, una reformulación llevada a cabo también desde el punto de vista del razonamiento legal, ver el ensayo I.15 sec. IV, pp. 243-53 (1997b: "Commensuration and Public Reason").

Una reflexión posterior, más abstracta, de la mencionada "premise llave" se ofrece en los párrafos iniciales de Aquinas, capítulo IV.3, p. 111 :

Muchos piensan hoy en día que el problema fundamental de la teoría ética y política es huir del egoísmo — mostrar cómo y en qué sentido puede ser exigido, con razón, a otorgarle peso a los intereses de otros contra los de uno mismo, y a reconocer por lo menos algunos deberes morales hacia otra gente- Las teorías se 
construyen para exponer la racionalidad y/o la primacía natural de la "prudencia" egoísta, y para explorar la pregunta acerca de cómo tender un puente entre esa prudencia (en la orilla de acá) y la moralidad (en la orilla de enfrente). Desde el punto de vista de Aquino, estas reflexiones y teorías están mal concebidas.

Las únicas razones que tenemos para la elección y la acción son las razones básicas, los bienes y fines hacia los cuales nos dirigen los primeros principios prácticos. Esos bienes son bienes humanos; los principios no contienen ningún nombre propio, ninguna restricción como "...para mí" [nota a pie omitida]. Por lo cual no es meramente un hecho sobre el hombre animal, sino también y más importante, un testimonio para el entendimiento práctico de la gente, de que pueden estar interesados en el bienestar de un extraño, con quien nunca se volverán a encontrar, pero que ahora van tomando el camino equivocado y dirigiéndose a un precipicio [véase Cicerón, De Officiis, 3.5]; pues el bien(es) que el extraño y yo podemos compartir o perder es el mismo: específicamente, un bien(es) humano(s)...

En otros sitios de Aquinas se indica y se explica repetidamente que, y cómo, las emociones no sólo pueden desviar a la razón, sino que también son un acompañamiento constante y, en una psiquis bien ordenada, una ayuda para motivaciones inteligentes y razonables.

En las largas citas que acabo de leer, he estado mostrando uno de los modos en que la teoría desplegada en NLNR se desarrolló durante estos últimos 30 años, del mismo modo en que se desarrolló entre 1966 o 1970 a 1979 (cuando se envió a impresión). Hice esto en un recorrido textualmente complejo desde el trabajo de 1970 (no mencionado en la cita), a través de 1980 (el libro mismo) y a través de los ensayos de 1992 y 1997, y el libro Aquinas, hasta el Postscript de 2010/2011, dejando sin nombrar las primeras articulaciones del principio moral maestro en Fundamentals of Ethics, tres años después del "libro gordo" y de las más adecuadas articulaciones del principio en los trabajos conjuntos con Germain Grisez y Jospeh Boyle, publicados en 1987: "Prac- 
tical Principles, Moral Truth and Ultimate Ends" (en 32 American Fournal of Furisprudence) y en el libro Nuclear Deterrence, Morality and Realism. La complejidad textual, de todas formas, es meramente textual; el principio maestro es simple, como es también su fuente última en la inteligibilidad de cada uno de los bienes humanos básicos, entendidos cada uno por cada uno de nosotros, como tan buenos para ti o para cualquiera como para mí.

El Postscript indica, y hasta cierto punto discute, otros desarrollos de la teoría del libro, y señala algunos baches en la explicación que ofrece el libro de los asuntos humanos. Voy a enumerar algunas materias principales recogidas en este Postscript, y espero que me perdonen por repetir hasta cierto punto, aquí como en otros sitios, lo que ustedes ya han leído, estoy seguro, en el "Estudio preliminar" de Orrego, que en su informativa y perceptiva retrospectiva y guía del libro, "después de [podríamos decir] 20 años", incluye una guía a muchos de los desarrollos de la teoría subyacente posteriores a 1980.

Primero, entonces, el libro habría sido de mucha ayuda si hubiera apelado en forma directa al principio epistemológico fundamental para el trabajo de Santo Tomás: la naturaleza de un ser dinámico (como los seres humanos) se comprende comprendiendo esa clase de capacidades del ser, y esas capacidades se comprenden comprendiendo sus acciones, que a su turno sólo pueden ser adecuadamente comprendidas comprendiendo sus objetos - que en el caso de los seres humanos son los objetos del razonamiento práctico humano y de la elección: los bienes humanos básicos recogidos en los primeros principios de la razón práctica (que, como Aquino dice correctamente, per se nota e indemonstrabilia) - .

Segundo, el libro podría haber dicho más sobre la libre elección para definirla, mostrar su naturaleza radical, y defender su realidad contra el determinismo cientificista dominante (una extrapolación ilícita de las ciencias naturales). Tercero, debería haber usado una comprensión de la intención más exacta y con más adecuada capacidad explicativa (incluyendo tanto el objeto 
como la intención [remota] de un acto humano). Cuarto, útilmente y sin desviarse, podría haber dicho más acerca de las virtudes y su relación con los principios y las normas de la razón práctica. Quinto, debería haber dejado claro que las fuentes de la inconmensurabilidad de los bienes en juego en las elecciones moralmente significativas no sólo son la irreducible diversidad de los bienes humanos básicos, sino también la inconmensurabilidad - excepto por las normas morales - de las opciones particulares, aun si fueran opciones donde sólo un bien básico estuviera en juego. Sexto, la historia de la idea de derechos subjetivos debería haberle dado menos relevancia a la idea de un giro conceptual significativo o un hito entre Aquino y, por ejemplo, Grotius o las teorías contemporáneas de derechos. Séptimo, debería haber sido menos derrotista acerca de la capacidad de la razón filosófica de decir algo sobre la naturaleza o los atributos de Dios.

Hay una lista de cosas que el Postscript no menciona, pero sobre las cuales el libro hubiera tenido algo para decir si hubiera sido escrito 20 o 30 años después. Una de ellas es la idea de razón pública, tanto en el sentido útil de la frase, en el que a grandes rasgos se corresponde con la vieja frase "ley natural", como en el desorientador e indeseable sentido en que es usado por John Rawls, cuya teorización insatisfactoria y engañosa fue abordada, en algunos de mis ensayos, desde aproximadamente 1997. Otra es la idea del espíritu, esto es, del alma racional (en primera instancia, el alma humana), que la introducción al volumen II de mis Collected Essays se esfuerza por hacer explícita. No estoy del todo seguro de arrepentirme por no haberlo hecho en las páginas de NLNR. Ahí, la realidad del espíritu y sus implicancias, la libertad de elección, se da por sentada, pero se deja implícita, y hay límites para lo que puede voluntaria y seriamente ser tratado y considerado todo en un solo sitio, por la clase de lector que el libro tenía y que siempre tiene en mente: el incrédulo o por lo menos el joven no creyente occidental, receptor de la gravemente deformada cultura y educación cientificista de nuestra era. 
Otro asunto abordado en el segundo volumen de mis ensayos, el volumen titulado Intention and Identity, es la pregunta por las condiciones de identidad de las comunidades políticas, y en particular la significación de la identidad nacional y el impacto en ella de la etnicidad y la cultura profunda. Sobre esta materia, pienso que bien debería haber dicho algo. Pero no mucho. Otra vez, era una prioridad al escribir el libro que debería obviar obstáculos innecesarios a la recepción de sus tesis principales. Estas tesis debían ser libradas, en el mayor grado posible, de las distracciones provocadas por las actitudes y las ansiedades políticas de los lectores.

Contra el empirismo, el voluntarismo, el emotivismo, el prescriptivismo irracional, o el agnosticismo axiológico o el puro nihilismo axiológico de la gente cultivada que desprecia la teoría ética, política y legal de Platón, Aristóteles y Aquino, el libro necesitaba poner en claro lo que puede y debería ser dicho sobre la inteligibilidad de los bienes humanos, la prioridad de la inteligibilidad sobre la deseabilidad, y la base de toda obligación en esa misma inteligibilidad y consecuente deseabilidad. Este es el pensamiento conductor desde el comienzo hasta el final de la segunda parte, esto es, los capítulos 3 a 12. Se eleva a una explicitación y reflexión parcial en la discusión del imperium en el capítulo XI.8., una discusión cuya importancia estoy más inclinado a acentuar hoy que hace treinta años - sin olvidar que la explicación que hace Aquino del imperium de la razón en la estructura del acto humano fue rechazada e incluso objeto de burla por muchos de sus tempranos seguidores y por miembros posteriores de la escolástica española de Vitoria, Gabriel Vasquez y Suárez, con malas consecuencias que se extendieron hasta el día de hoy-.

La reflexión conductora del libro (como la acabo de denominar) me parece que ha tenido un impacto substancial, quizá especialmente en cuanto que ilumina las ideas de bien común, de la autoridad como una fuente de soluciones para los problemas de coordinación del derecho como la modalidad de autoridad exigida por comunidades con ambiciones razonables tan ex- 
tendidas como son las comunidades políticas, y de la obligación como la contra-parte de las responsabilidades de las autoridades políticas frente a quienes, sin embargo, la obligación no es debida (sino que es debida, en cambio, a los sujetos de derecho). En mi segunda conferencia exploraré un poco la extensión hasta la cual la filosofía jurídica de los últimos 30 años se involucró en, y en verdad acogió, las principales cuestiones y respuestas del libro durante los últimos 30 años. 
Estudios de teoría del derecho natural, editado por el Instituto de Investigaciones Jurídicas de la UNAM, se terminó de imprimir el 14 de diciembre de 2017 en los talleres de Desarrollo Gráfico Editorial, S. A. de C. V., Municipio Libre 175-A, colonia Portales, delegación Benito Juárez, 03300 Ciudad de México, tel. 5601 0796. Se utilizó tipo Baskerville en 9, 10 y 11 puntos. En esta edición se empleó papel cream book 57 x 87 de 60 gramos para los interiores y cartulina couché de 250 gramos para los forros. Consta de 500 ejemplares (impresión offset). 
- cabe duda que después de la Segunda Guerra Mundial y ante la transgresión del más elemental criterio de justicia, asistimos a lo que Heinrich Rommen llamó el "eterno retorno del derecho natural", un verdadero derecho que ante las exigencias sociales se renueva constantemente, aunque no falten esfuerzos que intenten opacarlo.

En los últimos tiempos, uno de los más importantes esfuerzos por renovar y actualizar el derecho natural lo constituye, sin duda, el realizado por el profesor emérito de la Universidad de Oxford, John Finnis, quien desde los presupuestos propios de la Analitic Jurisprudence ha podido reposicionar al derecho natural en el debate iusfilosófico contemporáneo.

El libro que el lector tiene en sus manos, así como toda la obra de John Finnis, se inscribe en lo que hoy podríamos decir constituye la característica esencial de la filosofía en general y de la filosofía del derecho en particular, esto es, la "rehabilitación de la razón práctica", razón ésta que no es otra cosa sino el esfuerzo que hace posible captar cuál es el telos de la acción humana y, en el caso del derecho, dirigir ésta a aquel conjunto de valores, fines y bienes de la realidad jurídica. Este posicionamiento no se presenta como antagonista del positivismo jurídico, sino como complementaria de la misma y única realidad jurídica. De este modo, y como lo muestra Finnis, el derecho se compone de dos elementos: la dimensión fáctico-social, en la que se incluyen las fuentes sociales del derecho, y la dimensión racional-valorativa, que provee a los sujetos jurídicos de razones para la acción. Esta última es la que justifica el deber de obediencia al derecho positivo.
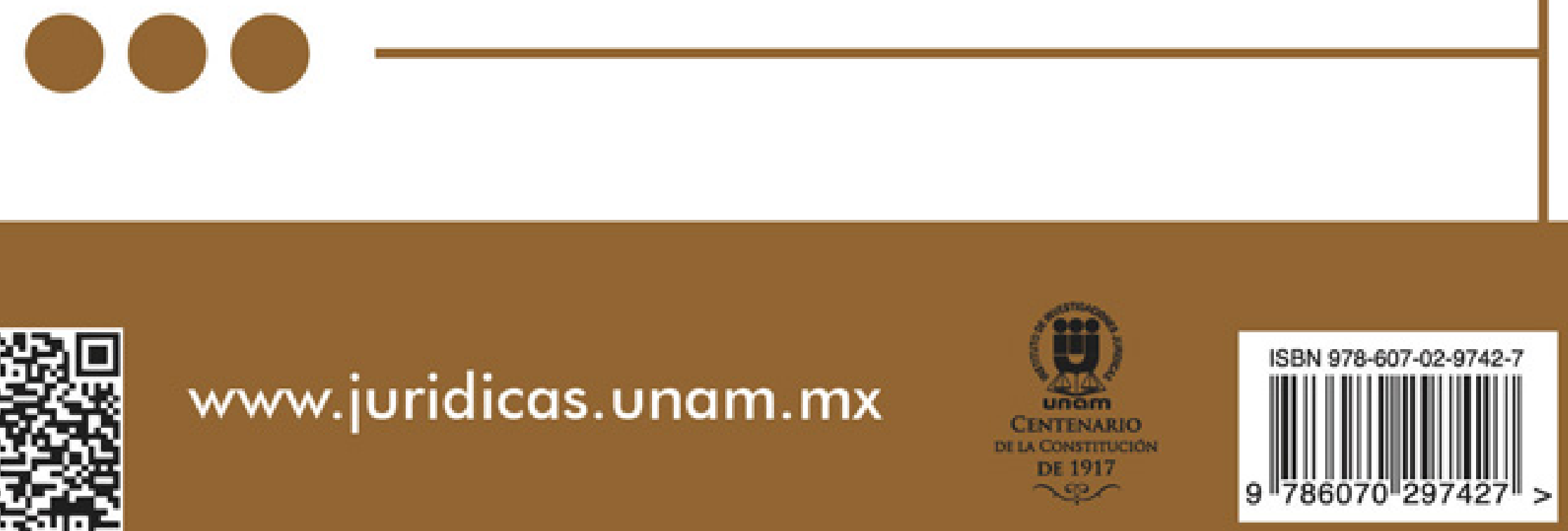